\title{
LOW SYMMETRY PINCER LIGANDS DESIGNED FOR APPLICATIONS IN COORDINATION CHEMISTRY AND CATALYSIS
}

by

\author{
Khrystyna Herasymchuk \\ Bachelor in Science, Chemistry \\ Ryerson University, Toronto, Ontario, Canada 2012
}

\begin{abstract}
A thesis presented to Ryerson University
In partial fulfillment of the

Requirements for the degree of

Master of Science

In the Program of

Molecular Science
\end{abstract}

Toronto, Ontario, Canada 2014

(C) Khrystyna Herasymchuk 2014 


\section{AUTHOR'S DECLARATION FOR ELECTRONIC SUBMISSION OF A THESIS}

I hereby declare that I am the sole author of this thesis. This is a true copy of the thesis, including any required final revisions, as accepted by my examiners.

I authorize Ryerson University to lend this thesis to other institutions or individuals for the purpose of scholarly research.

I further authorize Ryerson University to reproduce this thesis by photocopying or by other means, in total or in part, at the request of other institutions or individuals for the purpose of scholarly research.

I understand that my thesis may be made electronically available to the public. 


\title{
LOW SYMMETRY PINCER LIGANDS DESIGNED FOR APPLICATIONS IN COORDINATION CHEMISTRY AND CATALYSIS
}

\author{
Master of Science, 2014 \\ Khrystyna Herasymchuk \\ Molecular Science \\ Ryerson University
}

\begin{abstract}
Pincer ligands are monoanionic, tridentate binding molecules that have been used in coordination chemistry as efficient homogeneous and heterogeneous catalysts (i.e. as transition metal complexes). The focus of this work lies in the synthesis, characterization and coordination chemistry of a series of novel asymmetric potentially monoanionic NN'N", NN'C and NN'P type pincer ligands with amide functionality derived from the skeleton of 2-(2'-anilinyl)-4,4-dimethyl-2-oxazoline. Modular approach to this synthesis has been developed through an alkyl halide intermediate, in addition to the substrate-dependent alternative pincer syntheses, which are also described. The coordination chemistries of $\mathrm{Pd}$ and $\mathrm{Ni}$, as well as the potential application of these pincer complexes in metal mediated catalysis of aldehyde allylation reactions will be explored. Moreover, a number of $\mathrm{Pd}(\mathrm{II})$ pincer complexes have been successfully synthesized and structurally characterized and these results are likewise described.
\end{abstract}




\section{ACKNOWLEDGMENTS}

It has been four years, and five summers since I have met Dr. Gossage and was fortunate to work under his supervision. I would like to begin by thanking him for his mentorship and friendship, his true support and motivation during the course of this thesis, as well as some great giggles along the way.

I would also like to thank Dr. Koivisto and Dr. Viirre for their help, motivation, support and contribution to my work. Both of you are extraordinary chemists and educators and I feel so fortunate to have been your student.

A sincere thanks goes to Dr. McWilliams and Dr. Wylie for taking their time to read my thesis and help me make it even better. My gratitude extends to Dr. Foucher, Dr. Wylie and

Dr. Gossage for their pivotal role in my career growth. As they opened their doors to a student volunteer all those summers back. It is thanks to you that I am where I am today.

Now onto the life-long friendships that have been synthesized during the course of this work and my studies at Ryerson. Michelle, friend, you have been there for me even when no other friend was, always caring, supporting and cheering me on all the way. You are truly the greatest friend one can ask for! I would like to also mention Jennifer, who has been working alongside with me and has helped me tremendously. You are the most humble and selfless person I know! How can I forget about the biggest distraction (yes, you beat Michelle) - Shane (a.k.a. Robin), thanks for your friendship and keeping the lab "safe". I want to thank Jeffrey, Tamara, Alina, Maryam, Mahroo, Grace, Aman, Billy, Devin, Nande and Jon for your friendship and support. Shout out to KHN202, KHE211 and KHE322C the friendliest environment and grads! Thank you all for being simply amazing people!

Special thank you goes out to the most important person in my life, Dima, whose love and support means the world to me. Thank you for always being there for me! 
To my parents,

Марії і Павлу 


\section{TABLE OF CONTENTS}

ABSTRACT

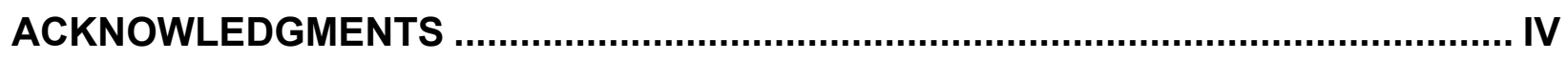

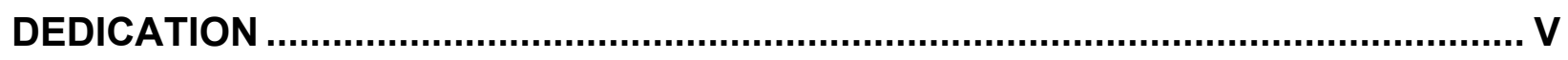

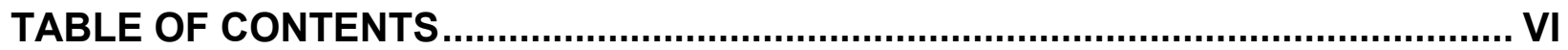

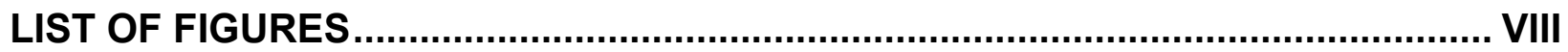

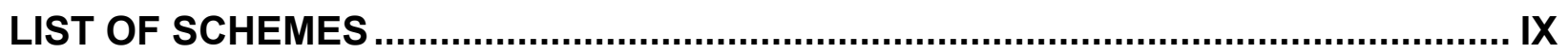

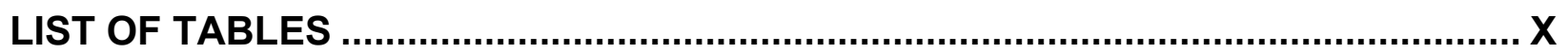

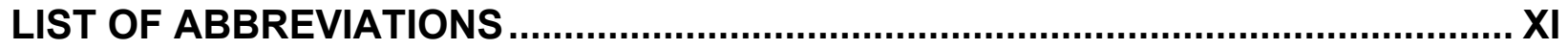

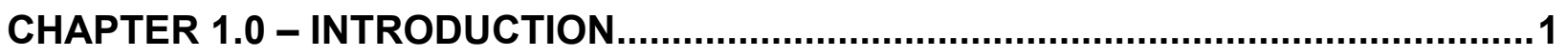

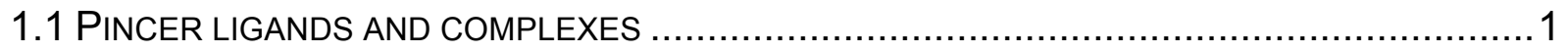

1.1.1 Oxazoline-containing pincer ligands and their complexes .......................... 3

1.1.2 Asymmetric pincer complexes in catalysis ............................................... 4

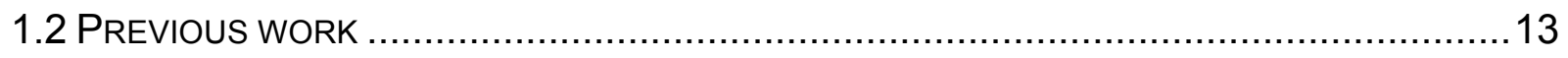

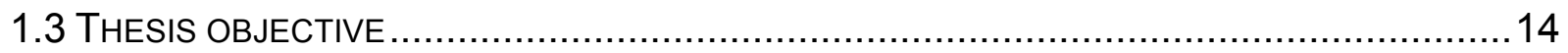

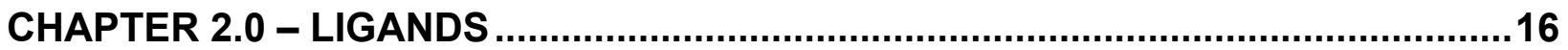

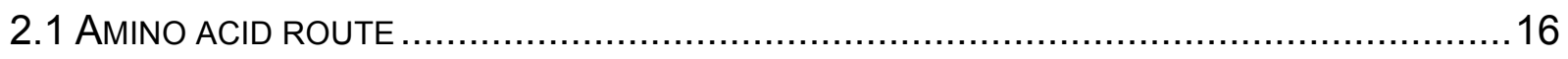

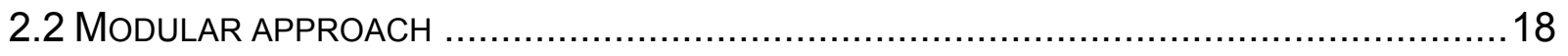

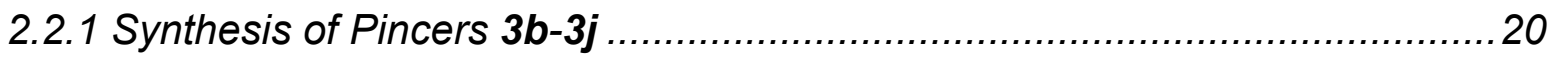

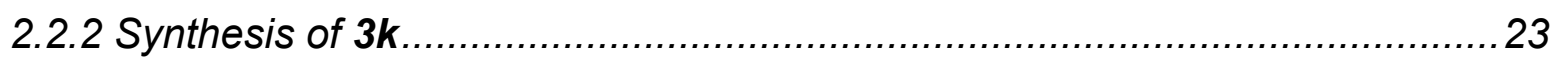

2.2.3 Synthesis of 3I: a carbene-pincer precursor .............................................25

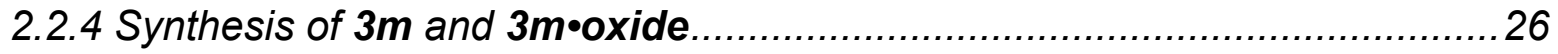

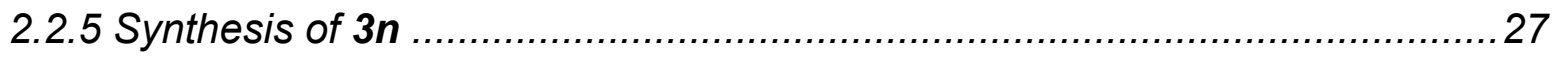

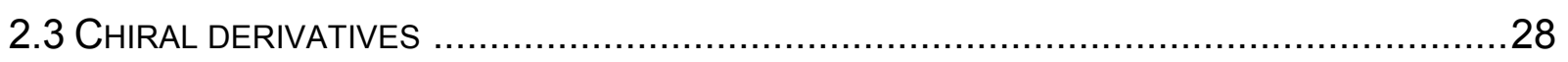

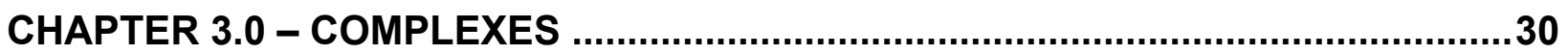

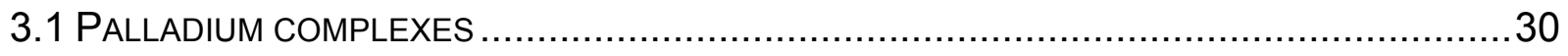




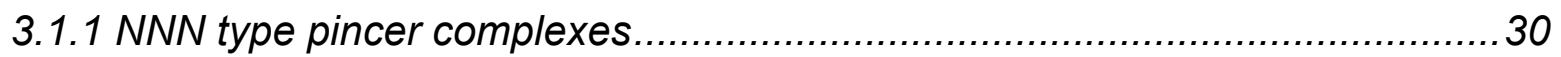

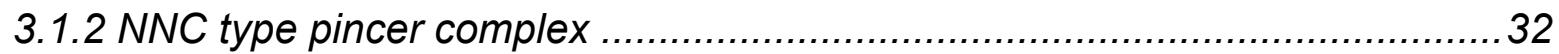

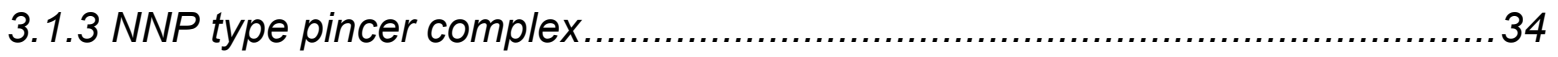

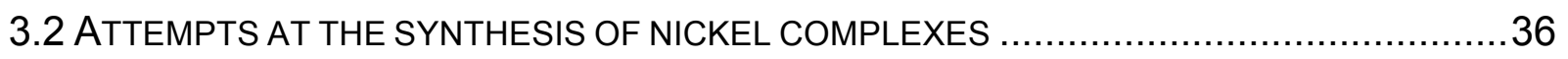

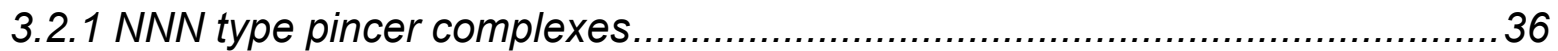

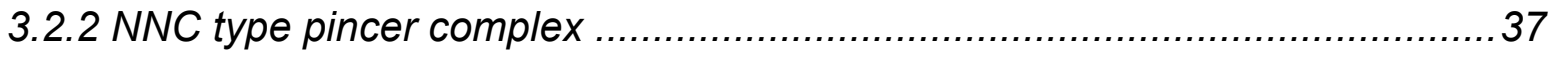

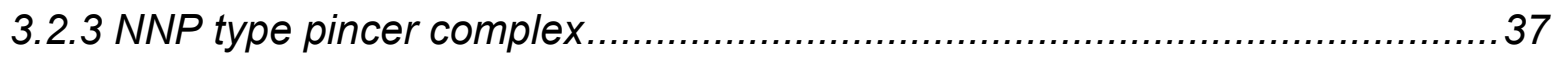

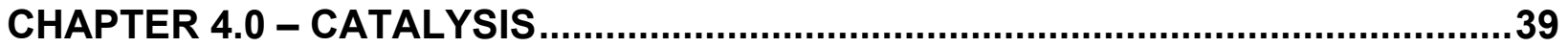

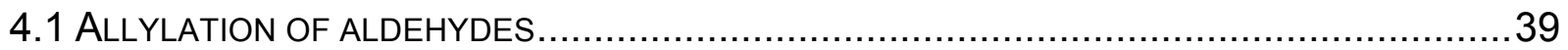

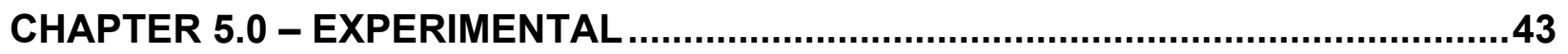

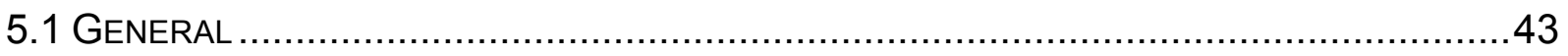

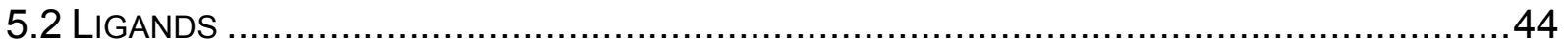

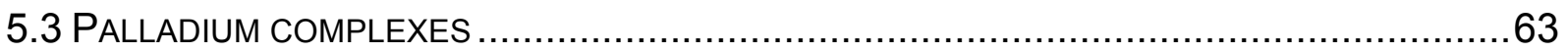

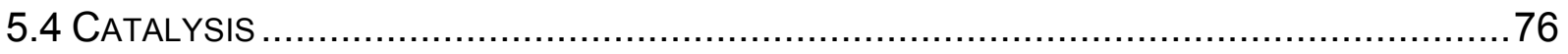

CHAPTER 6 - CONCLUSION AND FUTURE WORK .................................................

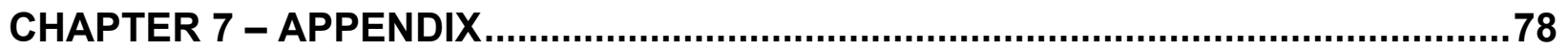

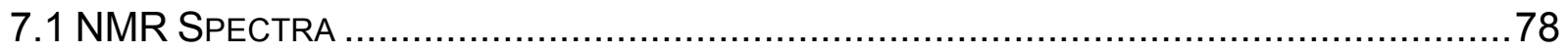

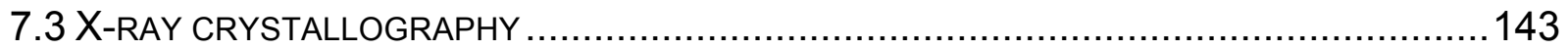

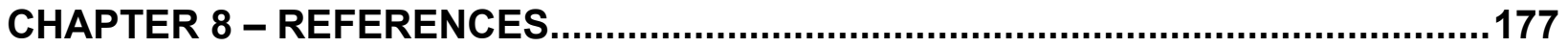




\section{LIST OF FIGURES}

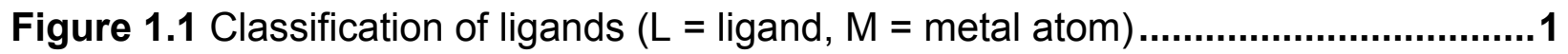

Figure 1.2. General depiction of a pincer ligand, where $M=$ metal, $L=$ ancillary ligand

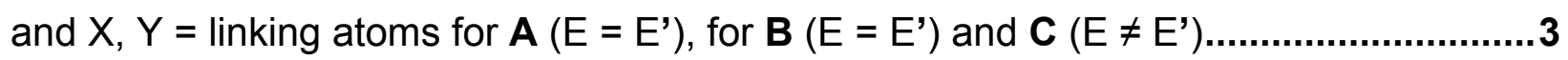

Figure 1.3 Structure of oxazoline (4,5-dihydro-2-oxazoline) .......................................4

Figure 1.4 Structures of $\left.\left[\mathrm{PdCl}_{2} \text { (2-ethyl-2-oxazoline) }\right)_{2}\right]$ (D) and 1,3-bis-(4,4-dimethyl-2-

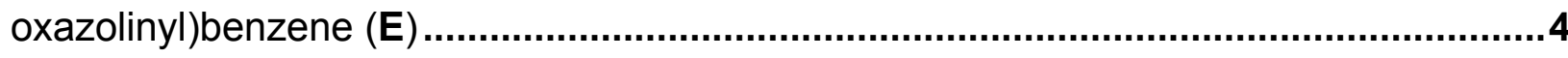

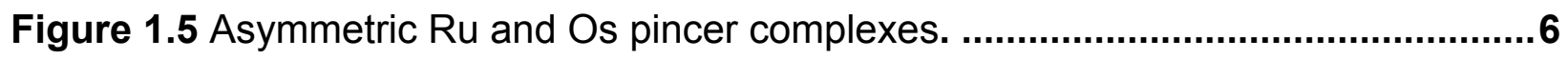

Figure 1.6 Ru complex with NNC pincer ligand .............................................................

Figure 1.7 Asymmetric NNC pincer complexes with $\mathrm{Ru}, \mathrm{Rh}, \mathrm{Pd}$ and $\mathrm{Au}$........................9

Figure 1.8 Pd(II) complex with NNC pincer type ligand ...............................................10

Figure 1.9 Ru(II) complex with NNP pincer ligand.......................................................12

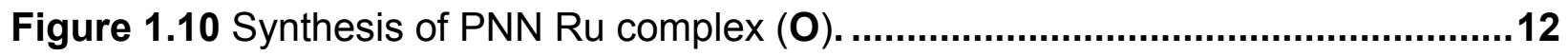

Figure 1.11 Structures of NNN pincer ligand $(\mathbf{P})$ and Cu NNN pincer complex $(\mathbf{Q}) \ldots . .14$

Figure $1.12 \mathrm{~K}^{4}$-PNN'O pincer-like complexes with an amide moiety.............................14

Figure 1.13 Classification of $N N^{\prime} L$ type pincer complex $(M=$ metal, $L=$ ligand $) \ldots . . . . . . .15$

Figure 2.1 X-ray crystal structure of $\mathbf{2}$ (on the left; solved by Alan Lough) and calculated (DFT) structure of 2 at the B3LYP: $6-311++G^{* *}$ theory level (on the right) .....................19

Figure 2.2 X-ray crystallographic structure of 3 m•oxide (Solved by Laura $R$.

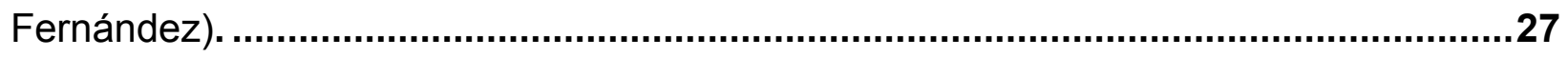

Figure 2.3 X-ray crystal structure of 6 (Solved by Robert A. Gossage).........................29

Figure 3.1 Crystal structures of 9 a (left) and 9 h (right) solved by Laura R. Fernández $\mathbf{3 1}$

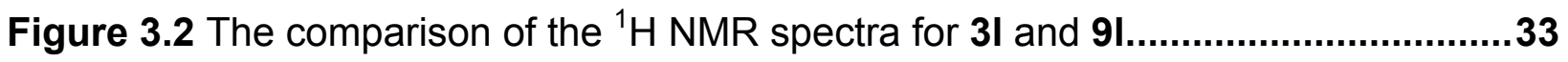

Figure 3.3 Select ${ }^{1} \mathrm{H}$ chemical shifts for $3 \mathrm{~m} \bullet 0 x i d e$ and $9 \mathrm{~m}$, depicting splitting effect ...35 


\section{LIST OF SCHEMES}

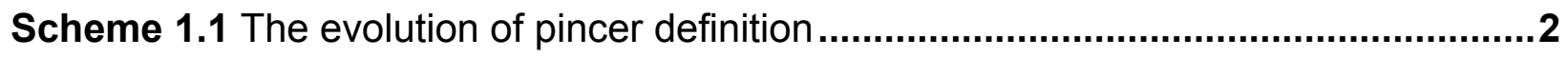

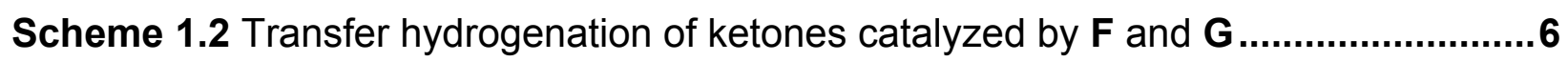

Scheme 1.3 Catalytic transformations using Ru NNC pincer complex, $\mathbf{H}$......................

Scheme 2.1 Synthesis of NNN type pincer ligand using 1 and amino acids ................16

Scheme 2.2 Synthesis of NNN type pincer ligand from $N, N$-dimethylglycine................16

Scheme 2.3 Synthesis of compound 2 - pincer precursor ........................................18

Scheme 2.4 Synthesis of NNN type pincer ligands through a modular approach ..........21

Scheme 2.5 Synthesis of an extended pincer NNNO, 3k, from $N$-methylaminoethanol 24

Scheme 2.6 Synthesis of NNC pincer ligand, 3I from 1-benzylimidazole .......................25

Scheme 2.7 Synthesis of NNP pincer ligand, 3m, from potassium diphenylphosphide 26

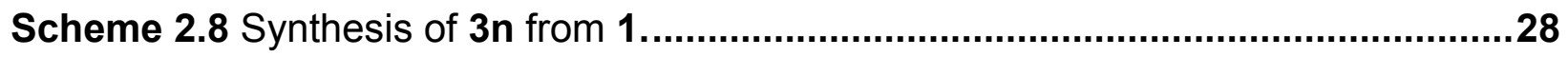

Scheme 2.9 Synthesis of the chiral derivatives, 6 and NNN type pincer ligand, $7 \ldots \ldots . .28$

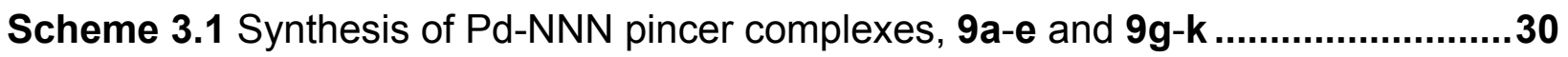

Scheme 3.2 Synthesis of Pd-NNC pincer complex, 9I ...............................................32

Scheme 3.3 Synthesis of Pd-NNP pincer complex, 9m ............................................34

Scheme 3.4 Synthesis of Ni-NNC type pincer complex from 3I ligand ...........................37

Scheme 3.5 Synthesis of Ni-NNP pincer complex...................................................38

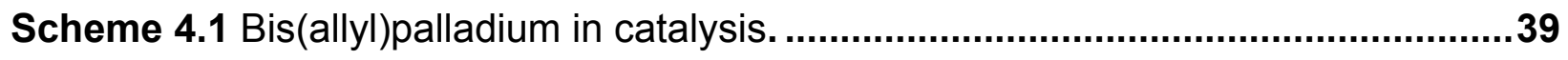

Scheme 4.2 Allylation of para-substituted benzaldehydes catalyzed by $9 \mathrm{~b} . . . \ldots \ldots \ldots \ldots . . . . .40$

Scheme 4.3 A proposed mechanism for the allylation of aldehydes .............................42 


\section{LIST OF TABLES}

Table 1.1 Heck and Stille cross-coupling reactions catalyzed by $\mathbf{M}$..............................11

Table 1.2 Transfer hydrogenation of ketones catalyzed by NNP Ru complex (0) ........13

Table 1.3 Esterification of primary alcohols catalyzed by Ru NNP complex (0) ...........13

Table 2.1 IR spectrum analysis for NNN type pincer ligands....................................17

Table 2.2 Experimental and calculated hydrogen bond lengths and angles for 2 .........19

Table 2.3 Select ${ }^{1} \mathrm{H}$ NMR chemical shifts and yields for 2 , 3a-3m•oxide, 6 and $7 \ldots \ldots . .22$

Table 2.4 Protection of the hydroxyl group on the $N$-methylaminoethanol ...................23

Table 2.5 Select literature and experimental ${ }^{31} \mathrm{P}$ NMR chemical shifts for PNN pincer.26

Table 3.1 Synthesis of Ni-NNN type pincer complex from $3 \mathrm{e}$ ligand ............................36

Table 4.1 Pd-NNN pincer complex-catalyzed allylation of select aldehydes .................41

Table 4.2 Comparison of ${ }^{1} \mathrm{H}$ NMR chemical shifts for aldehyde allylation reaction ........41 


\section{LIST OF ABBREVIATIONS}

\begin{tabular}{|c|c|}
\hline B3LYP & Becke 3 Lee Yang Parr \\
\hline $\mathrm{CDCl}_{3}$ & Chloroform- $\mathrm{d}_{1}$ \\
\hline DCC & $N, N^{\prime}$-Dicyclohexylcarbodiimide \\
\hline DCFC & Dry-column flash chromatography \\
\hline DCM & Dichloromethane \\
\hline DFT & Density functional theory \\
\hline DMAP & 4-Dimethylaminopyridine \\
\hline DME & Dimethoxyethane \\
\hline DMTMM & $\begin{array}{l}\text { 4-(4,6-Dimethoxy-1,3,5-triazin-2-yl)-4- } \\
\text { methylmorpholinium chloride }\end{array}$ \\
\hline Et & Ethyl \\
\hline $\mathrm{Et}_{2} \mathrm{O}$ & Diethyl ether \\
\hline $\mathrm{Et}_{3} \mathrm{~N}$ & Triethylamine \\
\hline EtOH & Ethanol \\
\hline $\mathbf{h}$ & Hour(s) \\
\hline IR & Infrared \\
\hline LDA & Lithium diisopropylamide \\
\hline Me & Methyl \\
\hline $\mathrm{MeCN}$ & Acetonitrile \\
\hline Mp & Melting point \\
\hline$n B u L i$ & Butyllithium \\
\hline NHC & $\mathrm{N}$-Heterocyclic carbene \\
\hline NMR & Nuclear magnetic resonance \\
\hline $\mathbf{P h}$ & Phenyl \\
\hline $\mathbf{R}_{f}$ & Retardation factor \\
\hline RT & Room temperature \\
\hline $\mathrm{S}_{\mathrm{N}} 2$ & Bimetallic nucleophilic substitution \\
\hline SPS & Solvent purification system \\
\hline tBuOK & Potassium tert-butoxide \\
\hline
\end{tabular}




\begin{tabular}{ll}
\hline THF & Tetrahydrofuran \\
TLC & Thin layer chromatography \\
TMSCI & Trimethylsilyl chloride \\
TOF & Turnover frequency \\
\hline
\end{tabular}




\section{CHAPTER 1 - INTRODUCTION}

\subsection{PINCER LIGANDS AND COMPLEXES}

Even though coordination compounds have existed for a long time, it was not until the late nineteenth century that Alfred Werner proposed the octahedral structures for $\mathrm{Co}(\mathrm{III})$ complexes, and as such pioneered this area of study. He was awarded the Nobel Prize in chemistry for his work on coordination compounds in 1913 and has since been referred to as the "Father of Coordination Chemistry"., ${ }^{1,2}$ In coordination chemistry, ligand can be defined as an ion or molecule bound to a metal atom through a coordinating bond, forming a coordination complex. This bond is due to an electron pair donation from the ligand to the metal. In contrast, a chelating ligand has two or more points of attachment to the metal centre. Ligands can also be described as mono-, bi-, tri-, tetra-, penta- and hexadentate, having one through six atoms of attachment, respectively (see Figure 1.1). ${ }^{3}$

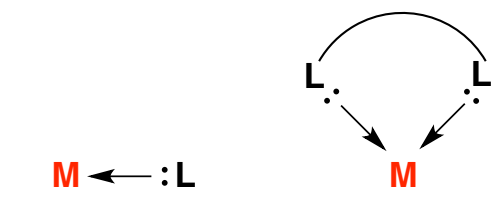

monodentate

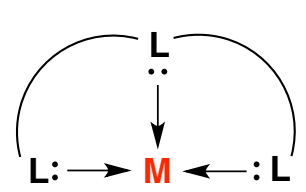

tridentate

Figure 1.1 Classification of ligands ( $L=$ ligand, $M=$ metal atom $)$.

Over the years chelating ligands have been of much interest and use for catalytic purposes. ${ }^{4,5}$ An important class of chelate chemistry is comprised of pincer ligands and their complexes. Ever since the original PCP type pincer ligand was reported by Molton and Shaw in $1976^{6}$ (Scheme 1.1) - pincer complexes have become prominent as homogeneous and heterogeneous catalysts in both organic synthesis and materials 
science.$^{7-12}$ But it was not until late 1980 s that this class of ligands received the name of the 'pincer', a term coined by the pioneer in the field - Gerard van Koten.

Pincers can be defined as tridentate ligands with one formal anionic coordinating atom and two neutral coordinating atoms binding to a central atom in typically a mer configuration. ${ }^{13,14}$ Over the years, this definition has been broadened (Scheme 1.1), and the scope of pincer chemistry has been extended to encompass various coordinating atoms (e.g., P, N, S, O). ${ }^{1}$ To control the property of a metal centre, the pincer ligand framework can be modified with respect to both steric and/or electronic features. This has led to the development of a large number of different types of pincer ligands. The coordination modes of pincer ligands in complexes have been found to be $L_{3}, L_{2} X, L X_{2}$, and $X_{3}$ (where $L=$ neutral atom and $X=$ anionic atom) $)^{15}$

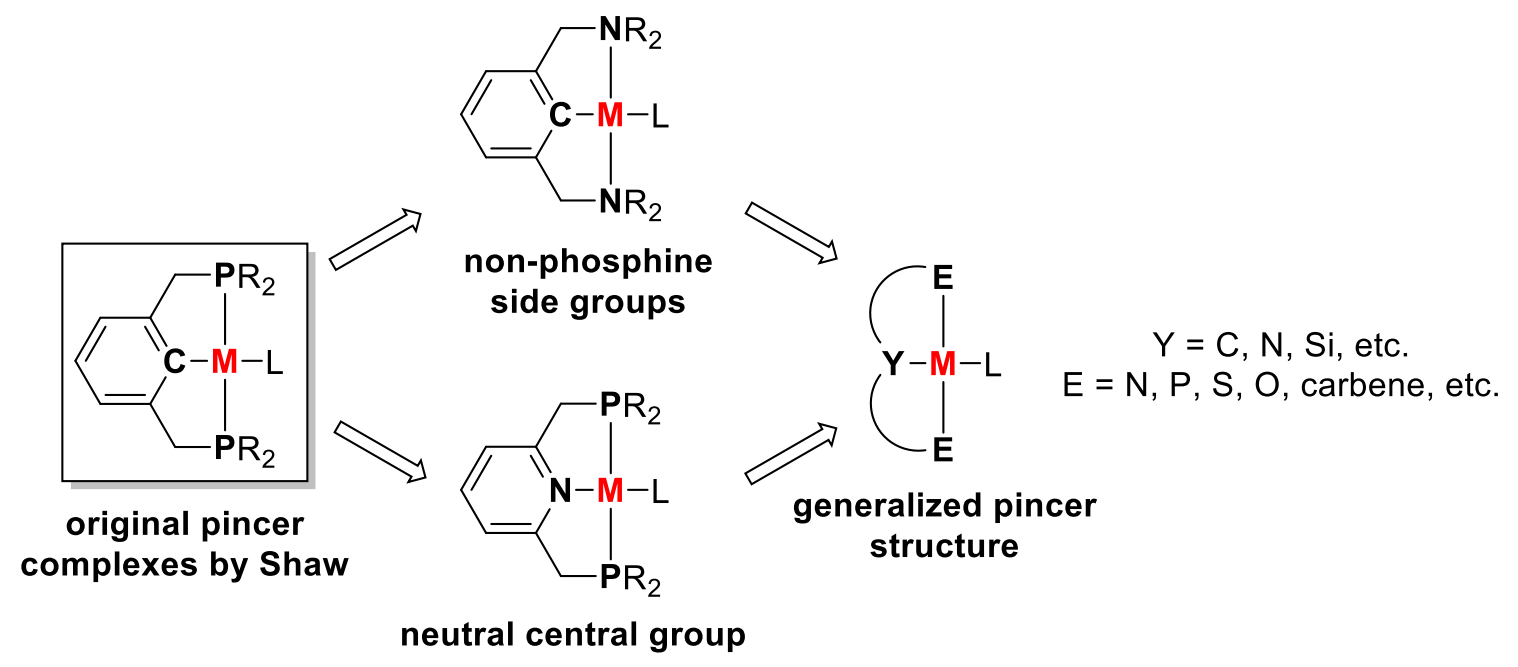

Scheme 1.1 The evolution of the pincer definition.

Depending on the character of the coordinating atoms on the pincer ligand, each individual M-ligand interaction can either be reinforced or competed against. For example, having $\sigma$-donating or $\pi$-accepting phosphanyl groups on a PCP pincer can either reinforce or compete against a $\sigma$-donating central aryl moiety - this provides a 
certain level of control over the dipolar nature of the pincer complex. ${ }^{16}$ The unique qualities of pincer ligands include: their typical high thermal stability, as well as imparting a greater reactivity to transition metal complexes versus those without pincertype ligands. ${ }^{16-18}$

From the onset of the pincer chemistry, the research focus lied on the ECE type pincer ligands with the central position having an anionic $C_{i p s o}$, (part of the phenyl ring), with two identical ortho substituents (A, Figure 1.2) ${ }^{19}$ Lately the research into pincer chemistry led to investigations of non-carbon monoanionic framework ${ }^{20}$ with two ortho moieties having different substituents, as well as having different $\mathrm{E}$ donor atoms all together, giving it $C_{1}$ point group symmetry (B or $\mathbf{C}$, Figure 1.2). The manipulation of a pincer ligand with respect to its structure is an endless endeavour.

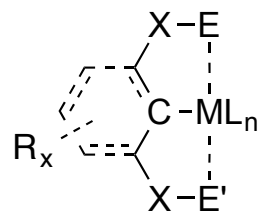

A

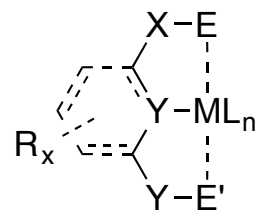

B

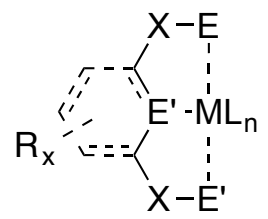

C

symmetric asymmetric $\left(C_{1}\right)$

Figure 1.2. General depiction of a pincer ligand, where $M=$ metal, $L=$ ancillary ligand and $X, Y=$ linking atoms for $\mathbf{A}\left(E=E^{\prime}\right)$, for $\mathbf{B}\left(E=E^{\prime}\right)$ and $\mathbf{C}\left(E \neq E^{\prime}\right) .{ }^{21}$

\subsubsection{Oxazoline-containing pincer ligands and their complexes}

The oxazoline, a subclass of oxazoles, is a five-membered heterocyclic organic compound with $\mathrm{O}$ and $\mathrm{N}$ atoms connected through an $\mathrm{sp}^{2}$ hybridized $\mathrm{C}$ atom (Figure 1.3). ${ }^{13}$ It plays an important role in transition metal chemistry, since oxazoline-based ligands have been investigated extensively in recent years and show great number of applications in homogeneous catalysis. ${ }^{22}$ 


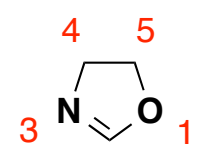

Figure 1.3 Structure of the oxazoline (4,5-dihydro-2-oxazoline) showing the typical numbering scheme.

Metal complexes formed with oxazoline moieties, combined with phosphorus, nitrogen or oxygen as donor atoms, often showcase interesting electronic properties associated with catalysis. ${ }^{22}$ For example, it has also been shown that $\mathrm{Pd}$ complexes containing oxazoline moiety (D, see Figure 1.4) have demonstrated oxidatively robust systems with respect to applications in cross coupling reactions. ${ }^{23}$
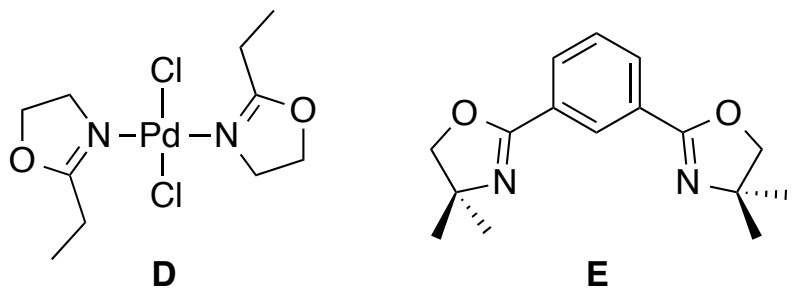

Figure 1.4 Structures of $\left.\left[\mathrm{PdCl}_{2} \text { (2-ethyl-2-oxazoline) }\right)_{2}\right]$ (D) and 1,3-bis-(4,4-dimethyl-2oxazolinyl)benzene (E).

Incorporation of an oxazoline moiety into pincer ligands has also been investigated. Coordination of pincer ligand $\mathbf{E}$ (Figure 1.4) and its derivatives has been studied with $\mathrm{Pt}$ and Pd metals, showcasing successful application in catalysis of carbon-carbon bond forming reactions. ${ }^{24-30}$

\subsubsection{Asymmetric pincer complexes in catalysis}

Since asymmetric pincer ligand complexes have gained the spotlight in the scientific community, their catalytic activity has been of great interest. Some of the reactions that they were found to catalyze include: ethylene polymerization, hydrogenation, transfer hydrogenation, dehydrogenation or oxidation (of alcohols), cyclopropanation, and such 
cross-coupling reactions such as the Kumada (coupling of an organic halide and Grignard reagent), Suzuki (coupling of an organic halide and boronic acid), Heck (coupling of an organic halide and an alkene) and Stille (coupling of an organo halide and organotin) coupling reactions. ${ }^{31-36}$

Transition metal pincer complexes have also shown great potential in stoichiometric and catalytic reactivity, ${ }^{19,37}$ however, chiral complexes have been investigated less because the auxiliary ligands have been responsible for the enantioselectivity in catalysis. ${ }^{7}$ Pincer complexes also exhibit high thermal stability and interesting properties of robustness, which make them even more desirable for homogeneous catalysis. ${ }^{37}$

The environmental aspect of any chemical transformation is greatly affected by the amounts and types of reagents used. That is why the use of catalyst is preferred over the use of stoichiometric amounts of reagents. ${ }^{38}$

One of the most important reactions involved in producing chiral alcohols is the asymmetric reduction of ketones. So far, $\mathrm{Ru}, \mathrm{Rh}$, Ir and $\mathrm{Os}$ complexes have been synthesized and successfully applied in ketone hydrogenation and transfer hydrogenation reactions. For Ru catalyzed process, the presence of an $-\mathrm{NH}_{2}$ group is crucial for the catalysis and formation of $\mathrm{Ru}-\mathrm{H}$ hydride, this relationship can be described as a metal-ligand bifunctional catalysis. ${ }^{32}$ Based on this find, Baratta et al. have developed new Ru (and Os) complexes with chiral asymmetric NNC pincer ligands that carry an $-\mathrm{NH}_{2}$ functionality. The presence of the $\sigma$ metal-carbon bond in these complexes has been shown to prevent catalyst deactivation and at the same time ensures high stability and productivity. During catalysis the Ru pincer complex is formed in situ, and hence had to be isolated separately to study in detail. ${ }^{39}$ 

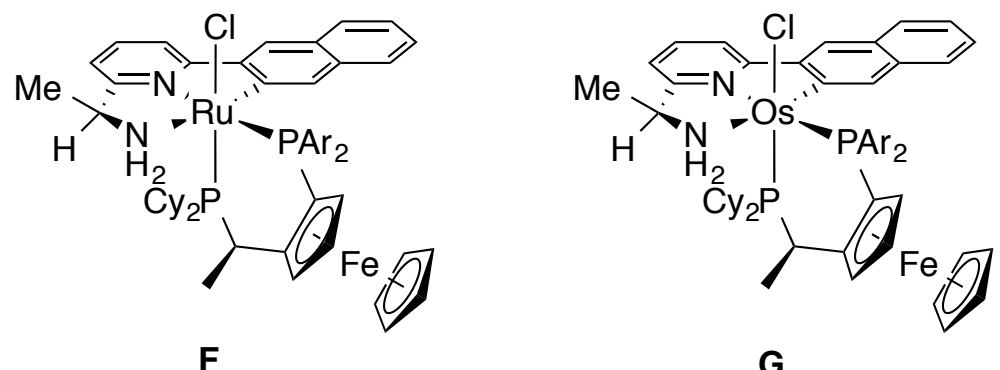

Figure 1.5 Asymmetric Ru and Os pincer complexes.

Preliminary catalytic study of Ru and Os complexes identified complex $\mathbf{F}$ and $\mathbf{G}$ as the most suitable candidates for further catalytic investigation. Transfer hydrogenation of ketones catalyzed by $\mathbf{F}$ and $\mathbf{G}$ showed promising results (Scheme 1.2), where ketones have been reduced to their secondary alcohol forms with $80-99 \%$ conversion, $92-99 \%$ ee and TOF ranging from 1.9 to $26 \times 10^{4} \mathrm{~h}^{-1}$ for $\mathbf{F}$ and $93-99 \%$ conversion, $90-99 \%$ enantioselectivity and TOF ranging from 5.1 to $90 \times 10^{4} \mathrm{~h}^{-1}$ for G. However, attempts at the reduction of sterically demanding ketones revealed low alcohol conversions of only up to $20 \%$. Overall, both Ru and Os NNC complexes used in transfer hydrogenation of ketones proved to be effective catalysts, with $\mathbf{G}$ having the greatest percentage conversion(s) and TOF. ${ }^{39}$

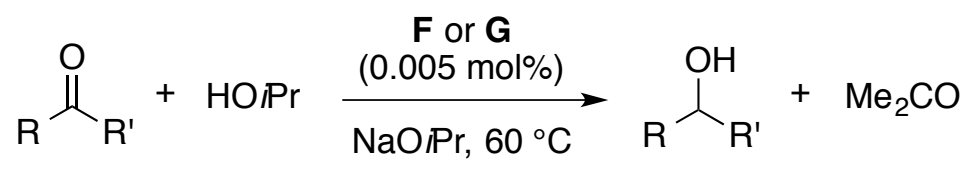

Scheme 1.2 Transfer hydrogenation of ketones catalyzed by $\mathbf{F}$ and $\mathbf{G}$.

In 2012, Du et al. reported a Ru catalyst with an unsymmetrical NNC pincer ligand (complex $\mathbf{H}$, Figure 1.6) that successfully catalyzes the transfer hydrogenation and Oppenauer-type dehydrogenative oxidation of alcohols, vide infra (Scheme 1.3). ${ }^{40}$ 


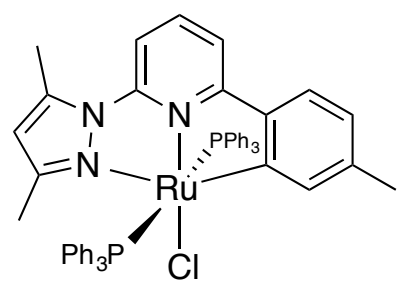

H

Figure 1.6 Ru complex with NNC pincer ligand

The complex $\mathbf{H}$ was characterized using NMR spectroscopy, and it was shown through $a^{31} \mathrm{P}\left\{{ }^{1} \mathrm{H}\right\}$ NMR spectrum that the two $\mathrm{PPh}_{3}$ are magnetically identical and are positioned trans to each other because of a singlet observed at $\delta_{p}=26.4 \mathrm{ppm}$. The complex was also characterized using X-Ray crystallography and was shown to have a neutral molecular structure with the NNC ligand in nearly a planar tridentate orientation. ${ }^{40}$

The transfer hydrogenation of ketones was carried out in 2-propanol under a nitrogen atmosphere in the presence of $0.1 \mathrm{~mol} \%$ of the catalyst, $\mathbf{H}$ (see Scheme 1.3). A variety of substituted ketones were transformed, including substituted acetophenones, aliphatic cyclic and acyclic ketones. Overall, the conversion of the ketones was observed to be greater than $98 \%$ within 1 min with TOF values of up to $18 \times 10^{4} \mathrm{~h}^{-1}$. The ketones with electron-withdrawing substituents on the aryl rings had a higher rate of reaction, whereas ortho substituted ketones had a reduced reaction rate due to the steric considerations. It should be noted that no transfer hydrogenation is observed in the absence of a base. ${ }^{40}$

The Oppenauer-type oxidation is a widely used method for production of carbonyl compounds without using stoichiometric amounts of oxidants. Similar to the transfer hydrogenation reactions above, the secondary alcohols undergo dehydrogenative oxidation with $\mathbf{H}(0.5 \mathrm{~mol} \%)$ with $t \mathrm{BuOK}(10 \mathrm{~mol} \%)$ in refluxing acetone (Scheme 1.3). 

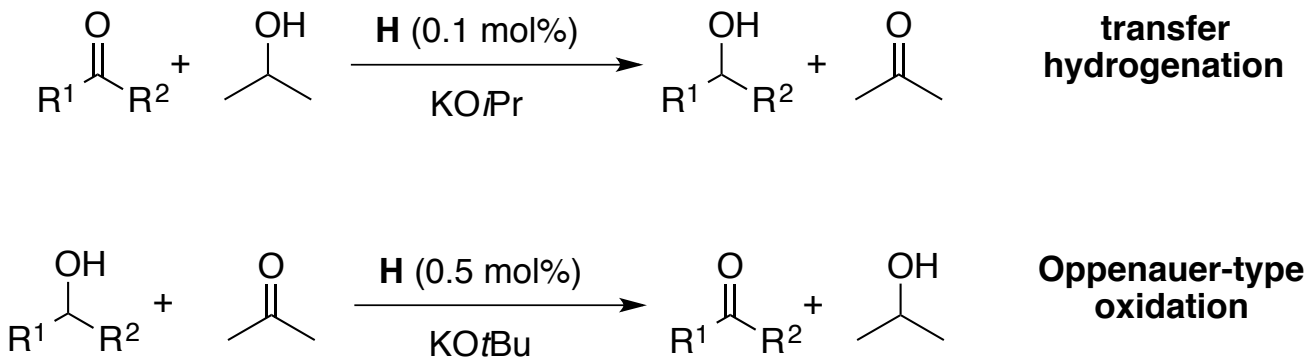

Scheme 1.3 Catalytic transformations using Ru NNC pincer complex, $\mathbf{H}$.

The oxidation of alcohols was successfully carried out from $1 \mathrm{~min}$ to $3 \mathrm{~h}$, averaging at conversions greater than $97 \%$ and with TOF values of up to $1.2 \times 10^{4} \mathrm{~h}^{-1}$. This catalytic activity represents one of the best reported to date. ${ }^{40}$

The coordination of the $\mathrm{Ru}, \mathrm{Rh}, \mathrm{Pd}$ and $\mathrm{Au}$ with NNC pincer ligands was reported to work through Lin's method of transmetallation. ${ }^{38}$ Reacting the NNC pincer ligands with $\mathrm{Ag}_{2} \mathrm{O}$ in $\mathrm{DCM}$ - produced a silver(I) intermediate complex. With the addition of each appropriate metal precursor to the reaction solution directly, allowed for the complexes I - $\mathbf{L}$ to be formed in excellent yields (>90\%). Upon coordination of the ligands, a new chiral centre is introduced in all of the complexes (Figure 1.7), and the coordination of $\mathrm{Ru}$ is completely stereospecific. ${ }^{38}$

Catalytic behaviour of I was tested on a hydrogenation reaction of diethyl citraconate and diethyl 2-benzylidenesuccinate. All the catalysts show high enantioselectivity and activity for the hydrogenation of diethyl 2-benzylidenesuccinate, the enantioselectivity is low with respect to the desired enantiomer, even though activity is high for the diethyl citraconate substrate. ${ }^{38}$ 


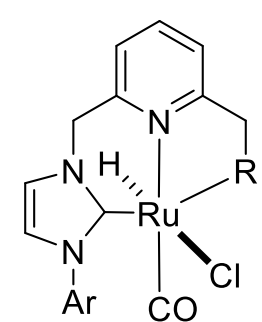

I

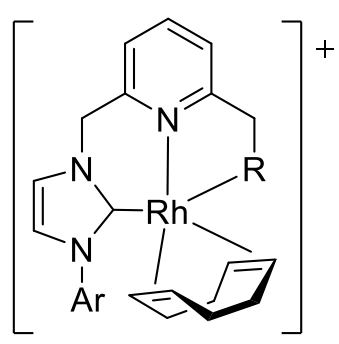

$J$

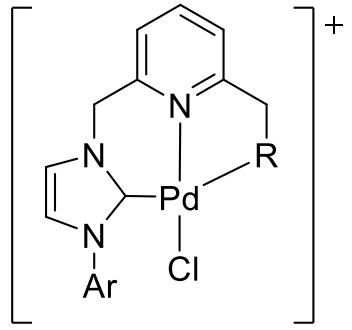

K

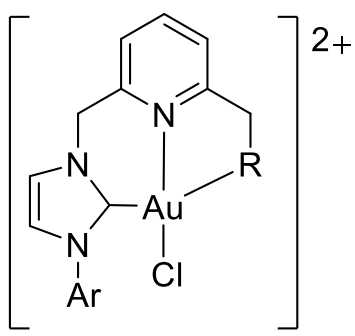

$\mathbf{L}$

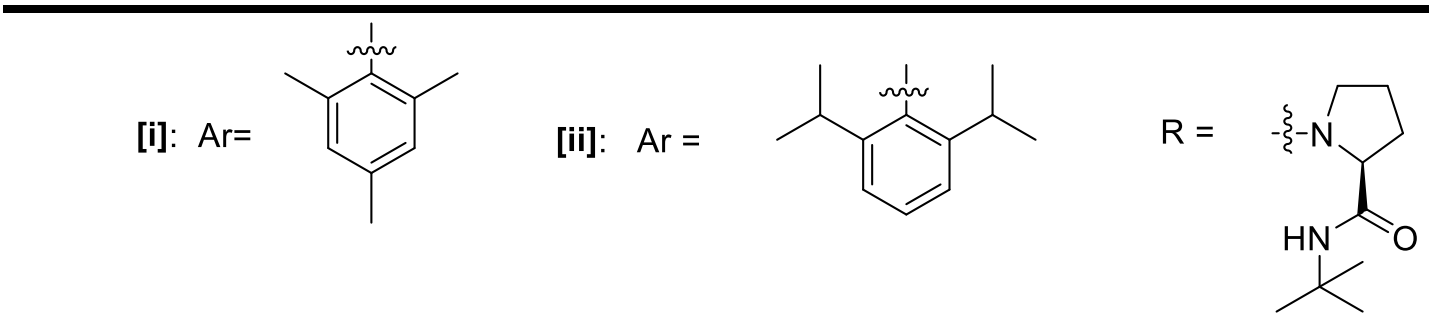

Figure 1.7 Asymmetric NNC pincer complexes with $\mathrm{Ru}, \mathrm{Rh}, \mathrm{Pd}$ and $\mathrm{Au}$.

Prior to the synthesis of NNC Ru complexes (I), Boronat et al. looked at the chemistry of the NNC pincer type ligand of $\mathrm{Rh}(\mathbf{J}), \mathrm{Pd}(\mathbf{K})$ and $\mathrm{Au}(\mathbf{L}) .{ }^{41}$ Catalytic activity of $\mathrm{Rh}$ complexes (J[i-ii]) was tested on hydrogenation of olefins, exhibiting high TOF but very low enantioselectivity for diethyl itaconate hydrogenation. Whereas, hydrogenation of diethyl 2-benzylidene succinate was successfully catalyzed by $\mathrm{J}[\mathrm{i}]$ with good enantioselectivity of $82 \%$ for the $S$ stereoisomer and J[ii] with excellent enantioselectivity (99\%) for the $R$ isomer. However, the reaction rates are much lower. ${ }^{41}$ Catalytic activity of $\mathbf{K}[\mathbf{i}]$ and $\mathbf{K}[\mathrm{ii}]$ was also tested on the hydrogenation of olefins as well. Just like with $\mathrm{Rh}$ and $\mathrm{Au}$, the reaction rate is higher for the hydrogenation of both diethyl itaconate and diethyl 2-benzylidene succinate catalyzed by $\mathbf{K}[\mathbf{i}]$, however the enantioselectivity with respect to the $S$ isomer is again very low. On the other hand, $\mathrm{K}$ [ii] shows superior enantioselectivity for the $R$ form with moderate reaction rate(s) for the hydrogenation of diethyl 2-benzylidene succinate. ${ }^{41}$ 
When the catalytic activity of $L[i]$ and $L[i i]$ was tested on hydrogenation of olefins, both Au complexes (L[i-ii]) showed great enantioselectivity in hydrogenation of diethyl 2benzylidene succinate with moderate reaction rates. However, the reaction rate(s) observed for diethyl itaconate hydrogenation was much higher for both of the $\mathrm{Au}$ catalysts, but the enantioselectivity was very low. ${ }^{41}$

Previous attempts at the synthesis of anionic isoindoline based NNC Pd complex resulted in a neutral NNC pincer. Broring et al. reported Pd complex coordinated to an anionic NNC pincer ligand (M, Figure 1.8) and its first application in catalysis. ${ }^{42}$

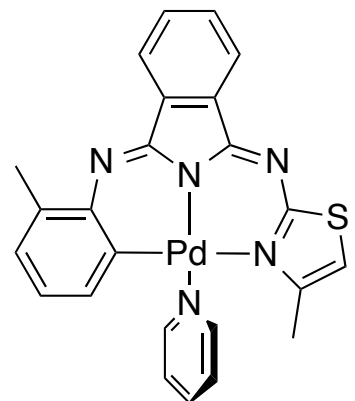

M

Figure 1.8 $\mathrm{Pd}(\mathrm{II})$ complex with an NNC pincer type ligand.

Complex $\mathbf{M}$ was characterized by both 1D and 2D NMR spectroscopy as well as X-ray crystallography, all supporting the proposed structure. The X-ray structure suggests an almost perfect square planar geometry around Pd and an unanticipated helical twist of the 2-tolti ligand. ${ }^{42}$

The catalytic activity of complex $\mathbf{M}$ was tested on Heck and Stille cross-coupling reactions; for comparison purposes $\mathrm{Pd}(\mathrm{OAc})_{2}$ was used as a standard (Table 1.1). When $\mathbf{M}$ was used in Heck cross-coupling reaction - the reactivity of the reaction decreases with $X=I>X=B r>X=C l$ as expected (with yields of $96 \%, 33 \%$ and $1 \%$, respectively). With an increase in steric hindrance (i.e. changing the substrates from $R_{1}$ 
$=\mathrm{R}_{2}=\mathrm{H}$ to $\mathrm{R}_{1}=\mathrm{R}_{2}=\mathrm{Me}$ ) the yield of the reaction decreased from $96 \%$ to $78 \%$, respectively. The same pattern was observed in the catalysis of Stille cross-coupling reaction. Moreover, steric hindrance effect was well-defined, the change in substrate $\left(R_{1}=R_{2}=H\right.$ to $\left.R_{1}=R_{2}=M e\right)$ yielded products from $40 \%$ to $20 \% .{ }^{42}$

Table 1.1 Heck and Stille cross-coupling reactions catalyzed by $\mathbf{M}$

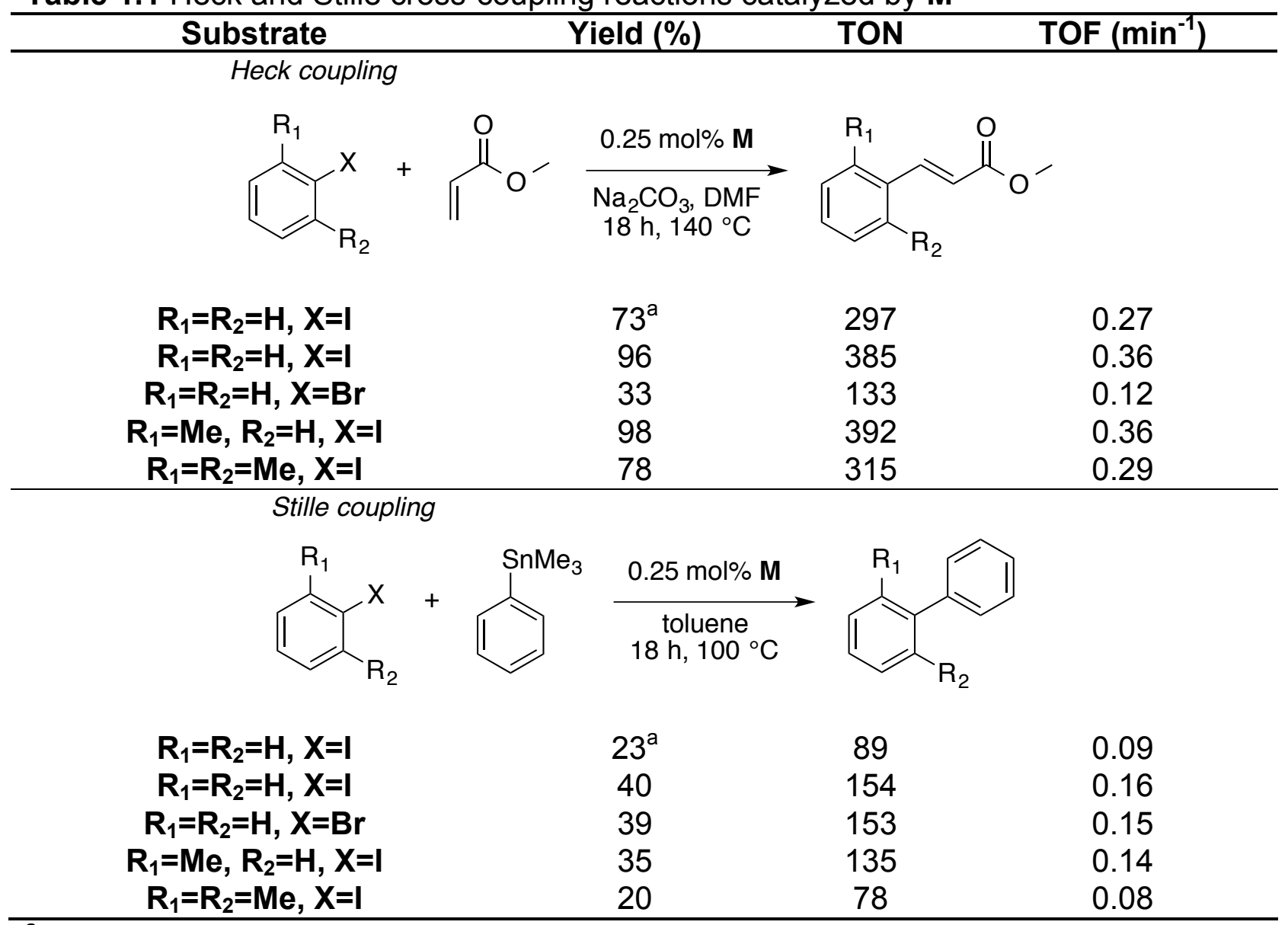

${ }^{a} \mathrm{Pd}(\mathrm{OAc})_{2}$ as the catalyst;

Dehydrogenation reactions are coupling reactions that can produce amides, imines, esters and ketones with elimination of $\mathrm{H}_{2}$. These reactions have been studied extensively, and have been shown to be successfully catalyzed by Ru complexes with NNP or PNP pincer ligands as part of their structure; in some cases in the presence of catalytic amounts of base. ${ }^{43,44} \mathrm{Li}$ and Zeng were able to propose the mechanism for the 
dehydrogenative coupling of alcohols with amines catalyzed by NNP-Ru(II) hydride complex (N, Figure 1.9) through density functional theory (i.e. DFT) calculations. ${ }^{43}$

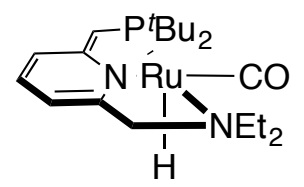

$\mathbf{N}$

Figure 1.9 Ru(II) complex with NNP pincer ligand.

Other mechanistic studies showed that addition of base is unnecessary in hydrogenation/dehydrogenation reactions if an NNP Ru hydrido complex is used. An example of such complex, $\mathbf{N}$, is an excellent catalyst for a vast amount of hydrogenation reactions, the coupling of alcohols and amines and the splitting of water into hydrogen and oxygen gas. ${ }^{44}$

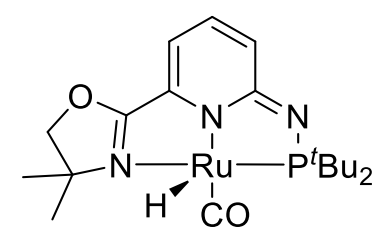

0

Figure 1.10 Synthesis of PNN Ru complex, $\mathbf{O}$.

The NNP Ru pincer complex, $O$ (Figure 1.10) was used in catalytic transfer hydrogenation reactions (Table 1.2) exhibiting product yields of up to $99 \%$. It was later tested on the esterification of primary alcohols (Table 1.3) giving the desired product in as high as $99 \%$ yield. As with transfer hydrogenation reactions, esterification of alcohols is catalyzed in the absence of a base. ${ }^{45}$ 
Table 1.2 Transfer hydrogenation of ketones catalyzed by NNP Ru complex (0).

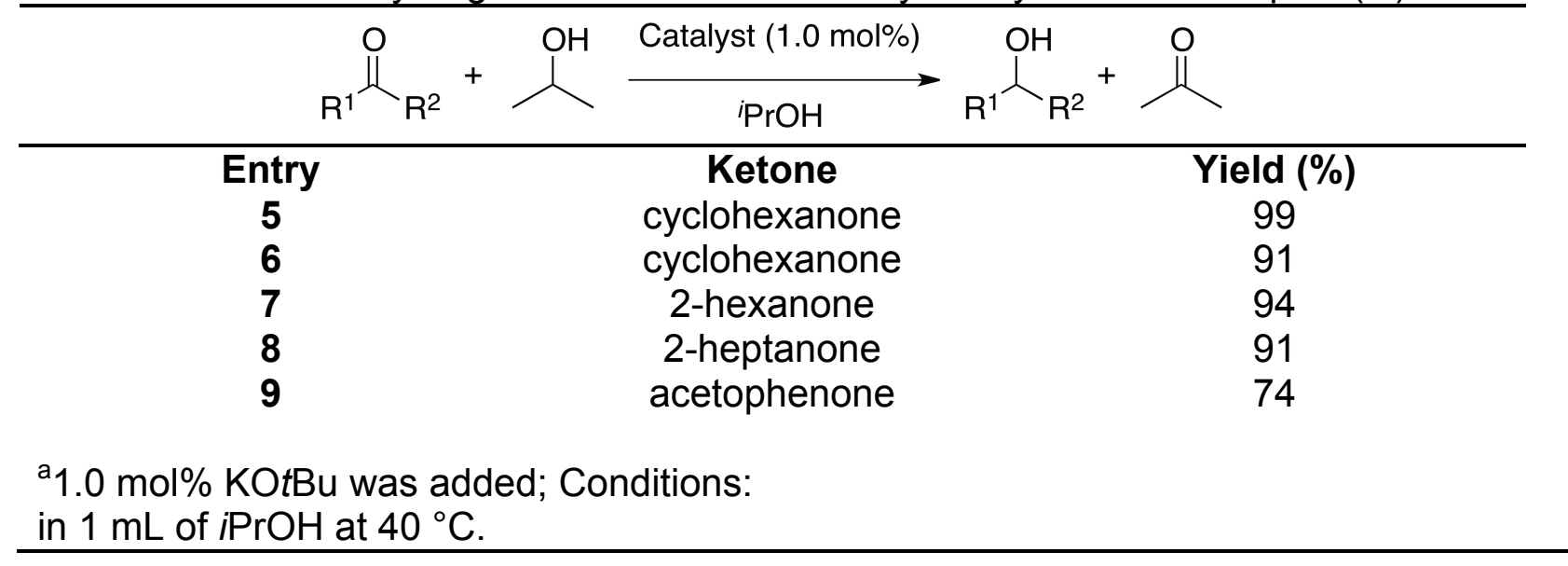

Table 1.3 Esterification of primary alcohols catalyzed by Ru NNP complex (0).

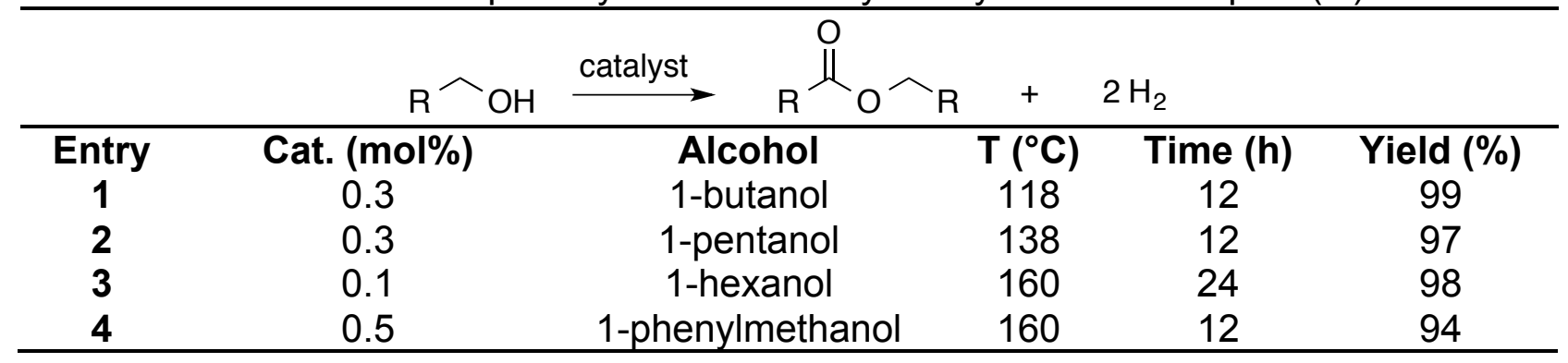

The examples detailed above give a strong background portfolio that clearly shows that metal-pincer complexes have great potential as asymmetric catalysts and stoichiometric promoters.

\subsection{PREVIOUS WORK}

Gossage et al. previously reported the synthesis of the formally $C_{1}$-symmetric amide pincer ligand (P, Figure 1.11) through the in situ chlorination of picolinic acid and its reaction with 4,4-dimethyl-2-(o-anilinyl)-2-oxazoline. ${ }^{46}$ 


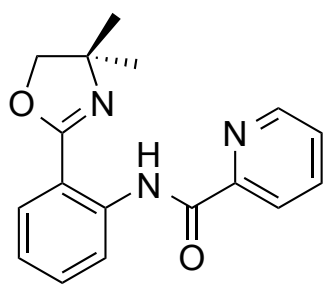

$\mathbf{P}$

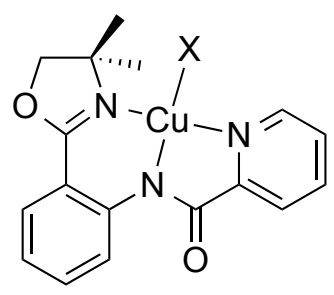

$\mathrm{X}=\mathrm{Cl}, \mathrm{Br}$

Q

Figure 1.11 Structures of NNN pincer ligand $(\mathbf{P})$ and Cu NNN pincer complex (Q). The coordination chemistry of $\mathrm{P}$ with $\mathrm{Cu}$ centres $(\mathbf{Q}$, Figure 1.11$)$ has been studied in the Gossage group with the purpose of applying these complexes in catalysis such as the Henry reaction. ${ }^{47}$ To our knowledge, the use of the amide moiety in the chelating ligands ( $\mathbf{N}$, as a monoanionic coordinating atom) has only been reported by Durran et al. in 2010 (R, Figure 1.12). ${ }^{48}$ The synthesis and complexation of the tetradentate ligands and their complexes with $\mathrm{Pt}(\mathrm{II}), \mathrm{Pd}(\mathrm{II})$ and $\mathrm{Ni}(\mathrm{II})$ were studied. ${ }^{48}$

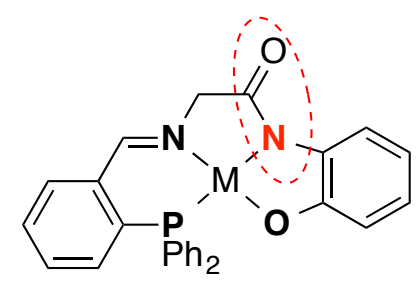

$\mathbf{R}$

$$
\mathrm{M}=\mathrm{Pt}, \mathrm{Pd}, \mathrm{Ni}
$$

Figure $1.12 \mathrm{~K}^{4}-\mathrm{PNN} \mathrm{N}^{\prime} \mathrm{O}$ pincer-like complexes with an amide moiety.

\subsection{THESIS OBJECTIVE}

The objective of this work lies in the design of the asymmetric pincer ligands of the NNN, NNC and NNP types (shown in Figure 1.13). The study of the coordination chemistry of these ligands with $\mathrm{Pd}$ and $\mathrm{Ni}$ metals as well as the application of the synthesized pincer complexes in catalysis will be explored. These monoanionic pincer 
ligands coordinate in a square planar fashion with $\mathrm{Pd}$ and $\mathrm{Ni}$. Catalytic investigations into their activity in $\mathrm{C}-\mathrm{C}$ bond forming reactions will be explored.

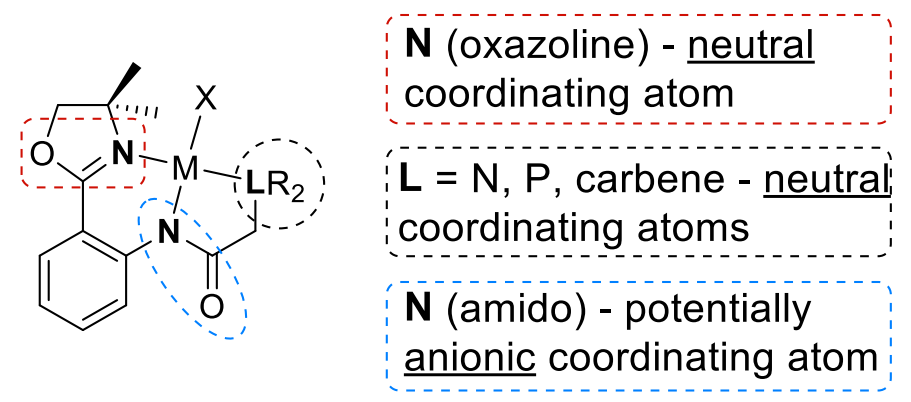

Figure 1.13 Classification of $N N^{\prime} L$ type pincer complex ( $M=$ metal, $L=$ ligand). 


\section{CHAPTER 2 - LIGANDS}

\subsection{Amino acid route}

Conversion of compound $\mathbf{1}$ into the respective pincer ligand was initially proposed to take place through an amide coupling with an appropriate amino acid. The formation of the amide bond could be attained either through the use of peptide coupling agents (i.e. DCC or DMTMM) or through the formation of an acyl chloride (Scheme 2.1)..$^{50,51}$

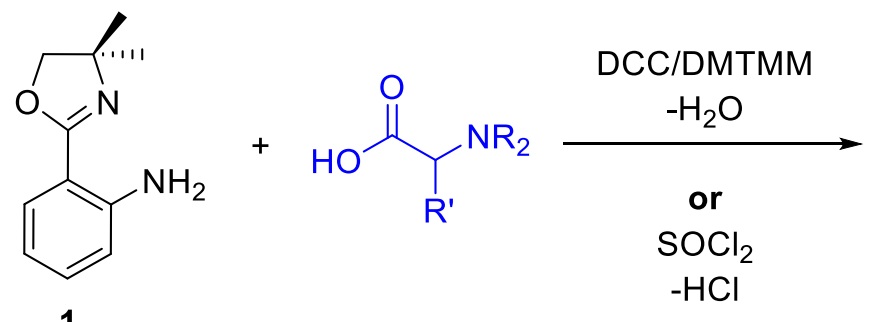

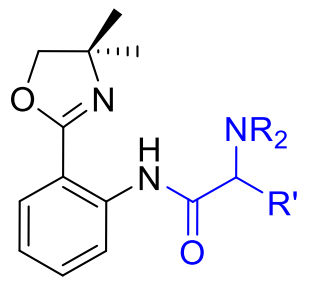

3

Scheme 2.1 Synthesis of NNN type pincer ligand using 1 and amino acids.

A more accessible route to pincer ligand synthesis was needed due to the prominent Zwitterionic effect of amino acids in aqueous solvents, their reactivity in non-polar organic solvents decreases substantially (equation 1) (i.e. Zwitterion - an overall neutrally charged molecule having both positive and negative charges). ${ }^{52,53}$

$$
\mathrm{Me}_{2} \mathrm{NCH}_{2} \mathrm{COOH} \leftrightarrow \mathrm{Me}_{2} \mathrm{NH}^{+} \mathrm{CH}_{2} \mathrm{COO}^{-}
$$

The magnitude of the tautomeric equilibrium for $\mathrm{N}, \mathrm{N}$-dimethylglycine is completely solvent dependent, and in most protic and aprotic polar solvents it exists in the Zwitterion form. ${ }^{52}$

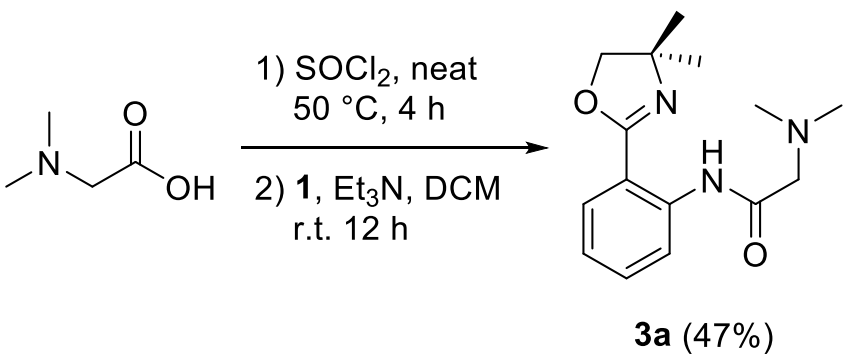

Scheme 2.2 Synthesis of NNN type pincer ligand from $N, N$-dimethylglycine. 
We previously showed that carboxylic group on the $N, N$-dimethylglycine can be transformed into the acyl chloride form using excess thionyl chloride under the neat conditions (Scheme 2.2) ${ }^{54}$ After the reaction of an amino acid and the thionyl chloride at $50{ }^{\circ} \mathrm{C}$, the excess thionyl chloride was removed and the resulted yellow solid compound, in situ generated $\mathrm{N}, \mathrm{N}$-dimethylglycinoyl chloride, was consequently reacted with compound 1 (primary amine) in the presence of $\mathrm{Et}_{3} \mathrm{~N}$ in DCM, which produced the desired pincer ligand, 3a (Scheme 2.2). The structure of this product was analyzed by $\mathrm{IR},{ }^{1} \mathrm{H}$ and ${ }^{13} \mathrm{C}$ NMR spectroscopy, and elemental analysis to successfully support the formula ${ }^{54}$ From the IR spectrum, the presence of a secondary amide $(\mathrm{N}-\mathrm{H})$ and an amide carbonyl $(\mathrm{C}=\mathrm{O})$ stretch/bend were observed and support the presence of the amide bond (Table 2.1).

Table 2.1 IR spectrum analysis for NNN type pincer ligands.

\begin{tabular}{|c|c|c|c|c|c|}
\hline Assignment & $3 \mathbf{a}$ & $3 \mathbf{b}$ & $3 g$ & $3 \mathrm{~h}$ & Literature $\left(\mathrm{cm}^{-1}\right)^{33}$ \\
\hline $\mathrm{C}=\mathrm{O}$ stretch $\mathrm{a}$ & 1677 & 1686 & 1683 & 1683 & 1680 \\
\hline $\mathrm{N}-\mathrm{H}$ bend $^{\mathrm{b}}$ & 1645 & 1641 & 1636 & 1643 & 1640 \\
\hline
\end{tabular}

${ }^{a}$ Amide carbonyl; ${ }^{b}$ Secondary amide;

Thirteen unique chemical shifts were observed in the ${ }^{13} \mathrm{C}$ NMR spectrum, agreeing with the formulation. From the ${ }^{1} \mathrm{H}$ NMR data, two singlet shifts were observed for the methylene groups $\left(\delta_{H}=4.05\right.$ and $\left.3.16 \mathrm{ppm}\right)$ and two for the equivalent methyl groups (2.39 and $1.41 \mathrm{ppm}$ ) integrating for 2 and 6 protons each, respectively. Four protons were also observed in the aromatic region (in the range from 7.07 to $8.84 \mathrm{ppm}$ ) with a distinct proton shift at $12.80 \mathrm{ppm}$ for the proton on the amide $(-\mathrm{NH})$ (see Table 2.3). The synthesis of highly functionalized pincer ligands using this route might be problematic, since the amino acid derivative would have to be exposed to harsh conditions when 
reacted with thionyl chloride, because thionyl chloride is extremely reactive and corrosive. Hence, a new synthetic strategy was devised.

\subsection{MODULAR APPROACH}

The need for the synthesis of easily accessible asymmetric pincer ligands led to the proposed use of 2-chloroacetyl chloride, as a building block to synthesize compound 2 a pincer precursor. 2-Chloroacetyl chloride is often used in organic chemistry to introduce amide bonds (by reacting through the acyl chloride) into a structure, thus providing a functionalizable end group (i.e. a chloromethyl group). ${ }^{55}$

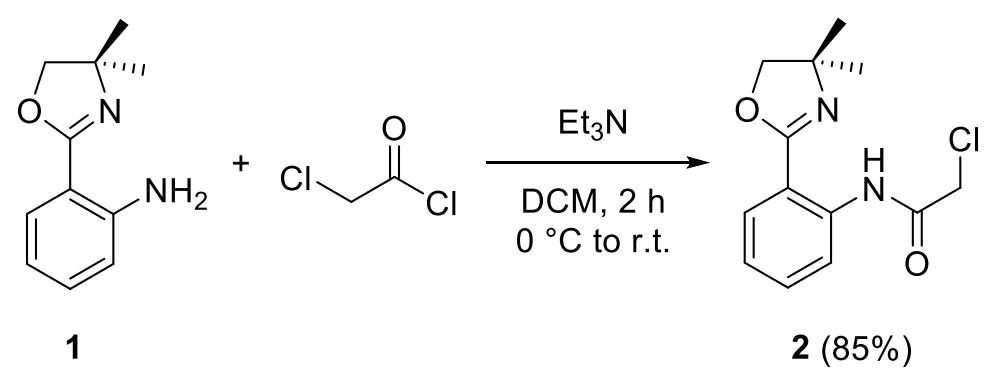

Scheme 2.3 Synthesis of compound 2 - pincer precursor.

Upon the addition of 2-chloroacetyl chloride to 1 in the presence of $\mathrm{Et}_{3} \mathrm{~N}$, the reaction mixture was stirred in DCM at room temperature (RT) for $2 \mathrm{~h}$. The desired product, 2 (Scheme 2.3), was obtained, upon gravity filtration and solvent evaporation, in $85 \%$ as an orange coloured crystalline solid. It was analyzed by X-ray crystallography (Figure 2.1, left), elemental analysis and ${ }^{1} \mathrm{H}$ and ${ }^{13} \mathrm{C}$ NMR spectroscopy. Both ${ }^{1} \mathrm{H}$ and ${ }^{13} \mathrm{C}$ NMR supported the proposed structure of $\mathbf{2}$. Two singlet shifts were observed for the methylene groups (4.21 and $4.07 \mathrm{ppm}$ ) and one for the two equivalent methyl groups (1.41 ppm) integrating for 2 each and 6 protons, respectively. Four protons were also observed in the aromatic region (in the range from 7.13 to $8.74 \mathrm{ppm}$ ) with a distinct 
proton shift at $13.05 \mathrm{ppm}$ for the amide proton $(-\mathrm{NH})$. Twelve unique carbon environments were observed in the ${ }^{13} \mathrm{C}$ NMR and supported the structure of 2.

From the crystallographic study of 2 (Figure 2.1, left), hydrogen bonding was reported for the amide hydrogen between both $\mathrm{N}$ and $\mathrm{Cl}$ atoms on the oxazoline ring $(2.03 \AA)$ and on the chloromethyl group (2.468 $\AA$ ), respectively (Table 2.2). Since crystal structures represent the molecule in the solid state, a DFT calculation was performed on 2 (Figure 2.1, right) to determine the theoretical behaviour of the compound in the gas phase, and to serve as a training exercise to familiarize oneself with the theoretical calculations using molecular modeling software.
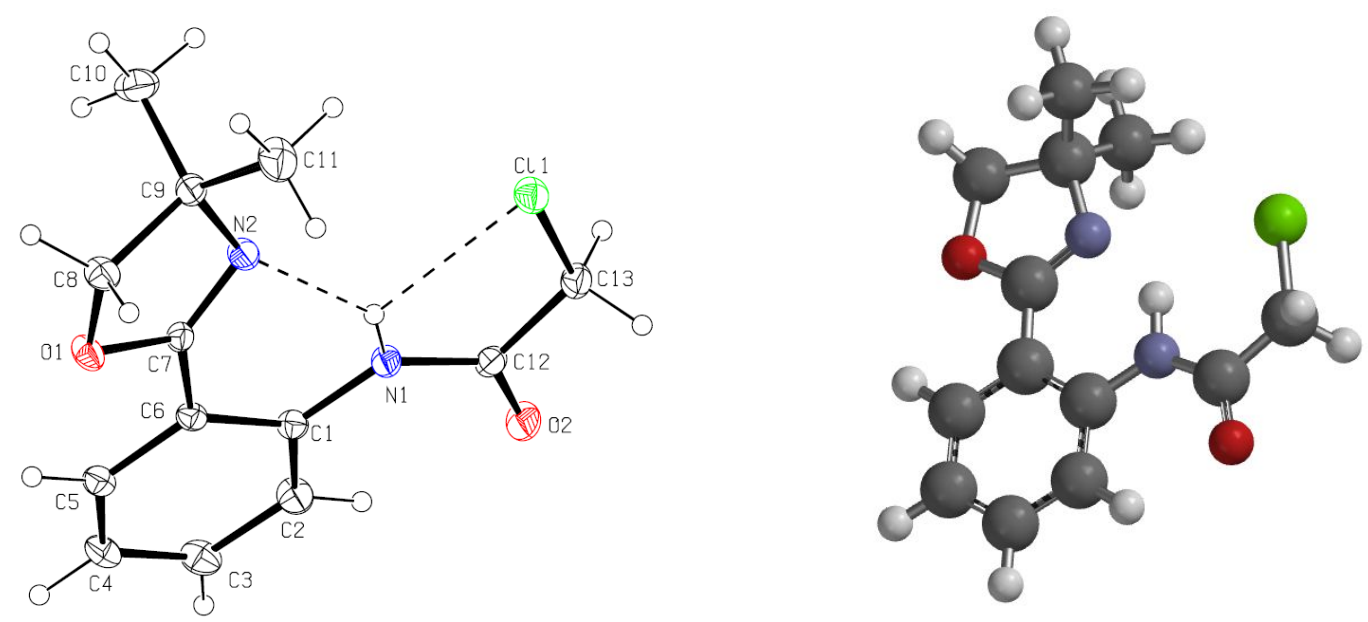

Figure 2.1 X-ray crystal structure of 2 (left; solved by Alan Lough) and calculated (DFT) structure of 2 at the B3LYP: $6-311++G^{* *}$ level of theory using Spartan'10 (right).

Table 2.2 Experimental and calculated hydrogen bond lengths and angles for 2.

\begin{tabular}{ccc|ccc}
\hline $\mathbf{D}-\mathbf{H} \ldots \mathbf{. . A}$ & $\mathbf{N}(\mathbf{1})-\mathbf{H} \ldots \mathbf{N}(\mathbf{2})$ & $\mathbf{N}(\mathbf{1})-\mathbf{H} \ldots \mathbf{C l}(\mathbf{1})$ & $\mathbf{D}-\mathrm{H} \ldots \mathbf{A}$ & $\mathbf{N}(\mathbf{1})-\mathbf{H} \ldots \mathbf{N}(\mathbf{2})$ & $\mathbf{N}(\mathbf{1})-\mathbf{H} \ldots \mathbf{C l}(\mathbf{1})$ \\
\hline$<(\mathrm{DHA})\left[^{\circ}\right]^{\mathrm{a}}$ & 138.4 & 112.5 & $\mathrm{D}(\mathrm{H} \ldots \mathrm{A})[\AA]^{\mathrm{a}}$ & 1.86 & 2.521 \\
$<(\mathrm{DHA})\left[\left[^{\circ}\right]^{\mathrm{b}}\right.$ & 138.9 & 118.9 & $\mathrm{D}(\mathrm{H} \ldots \mathrm{A})[\AA]^{\mathrm{b}}$ & 2.03 & 2.468 \\
\hline
\end{tabular}

${ }^{a}$ calculated value (DFT); ${ }^{b}$ experimental value (crystal structure)

The calculated angles and bond lengths for the three atoms involved in the abovementioned hydrogen bonding hydrogen agreed with the crystal structure values (see Table 2.2). The calculation was done at B3LYP with $6-311++G^{* *}$ basis set, with the 
geometry of the structure being in agreement with the crystal structure (Table 2.2); it should be mentioned that the structure of $\mathbf{2}$ was optimized several times starting from different geometrical orientations and hence Figure 2.1 (right) represents one of the likely gas phase configurations.

\subsubsection{Synthesis of Pincers $\mathbf{3 b - 3 j}$}

As previously stated, compound $\mathbf{2}$ was theorized to be a useful precursor for a modular synthetic approach, wherein this alkyl halide (2) can be reacted with selected secondary amines in the presence of the base to produce the desired pincer products. ${ }^{55}$ The reaction between a secondary amine and an alkyl halide can be classified as a nucleophilic substitution reaction (i.e. $\mathrm{S}_{\mathrm{N}} 2$ reaction). ${ }^{50}$ Therefore, the compounds $\mathbf{3 b} \mathbf{b} \mathbf{3} \mathbf{j}$ were synthesized by reacting 2 with the appropriate secondary amine in the presence of $\mathrm{K}_{2} \mathrm{CO}_{3}$ as the base, according to Scheme 2.4.

Pincer ligands $\mathbf{3 b} \mathbf{b} \mathbf{3} \mathbf{j}$ were thus synthesized in moderate to good yields, ranging from $30 \%$ to $74 \%$ (see Table 2.3). After the purification (see Section 5.2), the compounds were successfully analyzed by ${ }^{1} \mathrm{H}$ and ${ }^{13} \mathrm{C}$ NMR spectroscopy, as well as elemental analysis to support the proposed structures. Compounds $\mathbf{3 b}, \mathbf{3 g}$ and $\mathbf{3 h}$ were also analyzed by IR spectroscopy, confirming the presence of the amide bond through the presence of the typical $\mathrm{C}=\mathrm{O}$ stretch and $\mathrm{N}-\mathrm{H}$ bend absorption frequencies (see Table

2.1). The conversion of 2 into the appropriate pincer ligand product can be easily observed by a distinct proton NMR chemical shift of the amide (13.05 ppm for 2; see Table 2.3) functionality which shifts upfield for compounds $\mathbf{3 a - 3 j}$ (Table 2.3). The shift observed can be explained in terms of the increase in the strength of the hydrogen bonding (or an electronically donating interaction) between the $\mathrm{H}$ (on the amide) and $\mathrm{N}$ 
(of the tertiary amine) in $\mathbf{3 a - 3 j}$ due to the lone pair of electrons on the latter $\mathrm{N}$ atom; in comparison to the hydrogen bonding between the $\mathrm{H}$ (on the amide) and $\mathrm{Cl}$ (on the chloromethyl) as found in the crystal structure of 2 (Figure 2.1). Hence, shielding of the $-\mathrm{NH}$ proton is observed in $\mathbf{3 a - 3}$. Chiral derivatives, $\mathbf{6}$ and $\mathbf{7}$, were also synthesized and are discussed in Section 2.3.

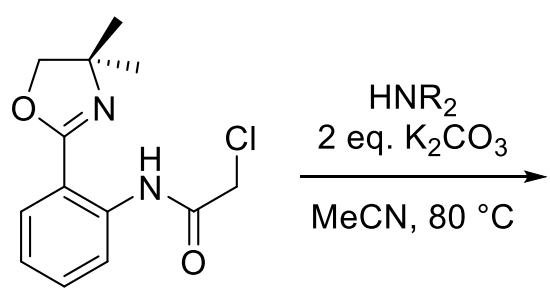

1<smiles>[R2]CC(=O)Nc1ccccc1C1=NC(C)(C)CO1</smiles>

$3 b-j$<smiles>CCN(CC)CC(=O)Nc1ccccc1C1=NC(C)(C)CO1</smiles>

3b $(69 \%)$<smiles>CC1(C)COC(c2ccccc2NC(=O)CN2CCCC2)=N1</smiles>

$3 \mathbf{e}(73 \%)$<smiles>C=CCN(C)CC(=O)Nc1ccccc1C1=NC(C)(C)CO1</smiles>

$3 \mathrm{~h}(41 \%)$<smiles>CN(CCc1ccccn1)CC(=O)Nc1ccccc1C1=NC(C)(C)CO1</smiles>

$3 c(45 \%)$<smiles>C[C@@H]1COC(c2ccccc2NC(=O)CN(Cc2ccccn2)Cc2ccccn2)=N1</smiles><smiles>CC(C)N(C)CC(=O)Nc1ccccc1C1=NC(C)(C)CO1</smiles>

$3 \mathbf{i}(66 \%)$

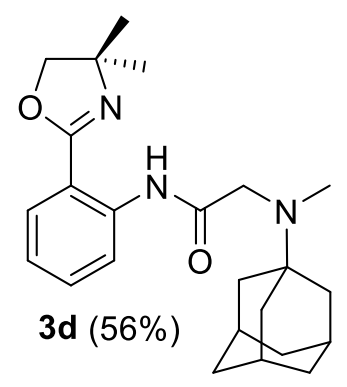<smiles>C[C@@H]1COC(c2ccccc2NC(=O)CN2CCOCCOCCOCCOCC2)=N1</smiles><smiles>C=CCN(CC=C)CC(=O)Nc1ccccc1C1=NC(C)(C)CO1</smiles>

Scheme 2.4 Synthesis of NNN type pincer ligands through a modular approach. 
Table 2.3 Select ${ }^{1} \mathrm{H}$ NMR chemical shifts and yields for $2,3 \mathrm{a}-3 \mathrm{~m} \bullet$ oxide, 5 and $\mathbf{6}$.

\begin{tabular}{|c|c|c|c|c|c|}
\hline & & $2,3 a-3 n$ & 5,6 & & \\
\hline Compound & $\mathbf{L}$ & $\mathbf{R}_{1}$ group & $\mathbf{R}_{\mathbf{2}}$ group & -NH shift (ppm) & $\begin{array}{c}\text { Yield } \\
(\%)\end{array}$ \\
\hline 2 & $\mathrm{Cl}$ & - & - & 13.05 & 85 \\
\hline $3 a$ & $\mathrm{~N}$ & Me & $\mathrm{Me}$ & 12.80 & 47 \\
\hline $3 b$ & $\mathrm{~N}$ & Et & Et & 12.64 & 69 \\
\hline $3 c$ & $\mathrm{~N}$ & $\mathrm{Me}$ & 2-Ethylpyridine & 12.65 & 45 \\
\hline $3 d$ & $\mathrm{~N}$ & Me & Adamantyl & 12.24 & 56 \\
\hline $3 e$ & $\mathrm{~N}$ & Pyrrolidine & - & 12.47 & 73 \\
\hline $3 f$ & $\mathrm{~N}$ & Picolyl & Picolyl & 12.57 & 30 \\
\hline $3 g$ & $\mathrm{~N}$ & 5-Crown & - & 12.52 & 67 \\
\hline $3 h$ & $\mathrm{~N}$ & $\mathrm{Me}$ & Allyl & 12.71 & 41 \\
\hline $3 \mathbf{i}$ & $\mathrm{N}$ & Me & $i \mathrm{Pr}$ & 12.63 & 66 \\
\hline $3 \mathbf{j}$ & $\mathrm{N}$ & Allyl & Allyl & 12.61 & 74 \\
\hline $3 k$ & $\mathrm{~N}$ & $\mathrm{Me}$ & $\mathrm{EtOH}$ & 12.22 & 88 \\
\hline 31 & $\mathrm{C}$ & - & - & 12.96 & 57 \\
\hline $3 \mathrm{~m} \cdot$ oxide & $\mathrm{P}$ & $\mathrm{Ph}$ & $\mathrm{Ph}$ & 12.43 & 55 \\
\hline 6 & $\mathrm{Cl}$ & - & - & 12.98 & 86 \\
\hline 7 & $\mathrm{~N}$ & Et & $\mathrm{Et}$ & 12.54 & 55 \\
\hline
\end{tabular}

Functionalization of $\mathbf{3 b} \mathbf{b} \mathbf{3} \mathbf{j}$ pincer ligands was achieved by using secondary amines: diethylamine (3b), 2-(2-methylaminoethyl)pyridine (3c), $N$-methyl- $N$-adamantylamine (3d), pyrrolidine (3e), 2,2'-dipicolylamine (3f), 1-aza-15-crown-5 (3g), N-allyl- $N$ methylamine (3h), $\mathrm{N}$-isopropyl- $\mathrm{N}$-methylamine (3i), diallylamine (3j). Compounds $3 \mathbf{c}$ and 3f were designed with an extended pincer motif - with the potential for the picolyl functional groups to chelate to a metal centre(s); increasing the coordination number to at least four for $\mathbf{3 c}$ and potentially five for $\mathbf{3 f}$. An extended pincer ligand, $\mathbf{3 f}$, can also be efficiently applied in homo- or heterobimetallic coordinating systems. Copper can be 
one of the potential candidates for a bimetallic study on 3f; Brown et al. recently showed a successful coordination and application of $\mathrm{Cu}$ with an N,N-bis(2-picolyl)benzamide ligand in methanolysis reactions, for example. ${ }^{56}$

\subsubsection{Synthesis of $\mathbf{3 k}$}

Pincer 3k was also synthesized since it contains an extended motif and therefore, having the potential to coordinate to the metal centre through four atoms (three $\mathrm{N}$ atoms and an $\mathrm{O}$ of the hydroxyl group). The synthesis of $\mathbf{3 k}$ followed the same procedure as for the $\mathbf{3 b} \mathbf{b} \mathbf{3} \mathbf{j}$, however prior to that the hydroxyl group on $N$-methylaminoethanol had to be protected due to its reactivity. Several protection reactions were performed on $N$ methylaminoethanol to protect the hydroxyl group (Table 2.4).

Table 2.4 Protection of the hydroxyl group on the $N$-methylaminoethanol.

\begin{tabular}{ccccc}
\hline Trial & Protecting group & Additive & Solvent & Product \\
\hline $\mathbf{1}$ & $\mathrm{Ac}_{2} \mathrm{O}$ & $\mathrm{DMAP}$ & $\mathrm{DCM}$ & $\mathrm{NO}$ \\
$\mathbf{2}$ & $\mathrm{TMSCl}_{\mathbf{H}}^{\mathrm{HMDS}}$ & $\mathrm{Et} \mathrm{t}_{3} \mathrm{~N}$ & $\mathrm{Et} \mathrm{t}_{2} \mathrm{O}$ & $\mathrm{NO}$ \\
$\mathbf{4}$ & $\mathrm{TMSCl}$ & $\mathrm{D}, \mathrm{L}-\mathrm{Aspartic}$ acid & $\mathrm{MeCN}^{-}$ & $\mathrm{NO}$ \\
& & - & $\mathrm{Et}_{2} \mathrm{O}$ & $\mathrm{YES}$ \\
\hline
\end{tabular}

Unsuccessful trials using acetic anhydride $\left(\mathrm{Ac}_{2} \mathrm{O}\right)$ with catalytic amounts of $\mathrm{N}, \mathrm{N}$ dimethylaminopyridine (DMAP), ${ }^{57}$ or hexamethyldisilazane (HMDS) with D,L-aspartic acid as a catalyst ${ }^{58}$ to protect hydroxyl group on the $\mathrm{N}$-methylaminoethanol resulted in unsuccessful outcomes (Table 2.4). The use of trimethylsilyl chloride (TMSCl) in combination with $\mathrm{Et}_{3} \mathrm{~N}$ in $\mathrm{Et}_{2} \mathrm{O}$ also did not produce successful results in protecting the hydroxyl group..$^{59}$ However, it has been recently shown that in the presence of 2 eq. of TMSCl in $\mathrm{Et}_{2} \mathrm{O}$ and in the absence of the base $\left(\mathrm{Et}_{3} \mathrm{~N}\right)$, the $\mathrm{N}$-methyl-2((trimethylsilyl)oxy)ethan-1-eminium chloride (4) was isolated in $81 \%$ yield. This material can be successfully used to synthesize an appropriate pincer, $\mathbf{3 k}$ (Scheme $\mathbf{2 . 5}$ ). ${ }^{60}$ 


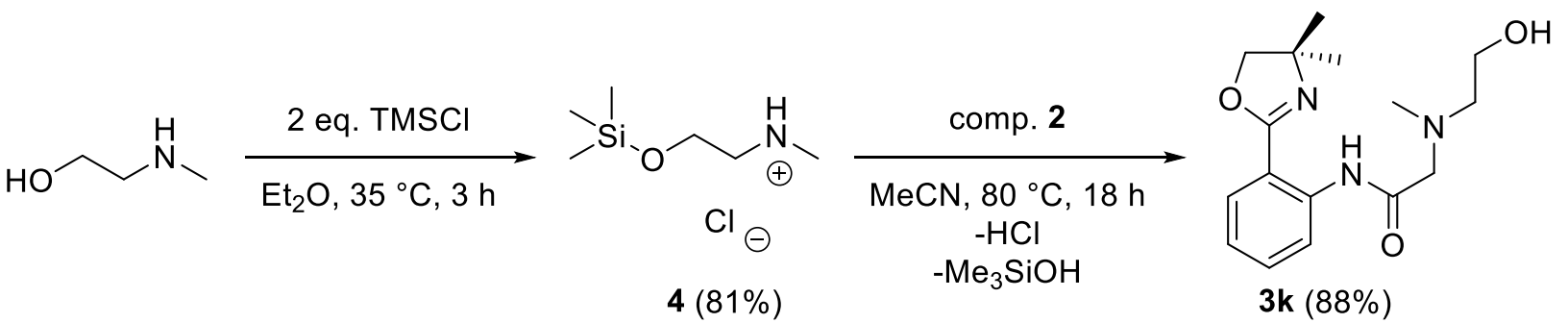

Scheme 2.5 Synthesis of an extended pincer NNNO, 3k, from $N$-methylaminoethanol.

Compound $\mathbf{4}$ was isolated and successfully characterized by elemental analysis and ${ }^{1} \mathrm{H}$ and ${ }^{13} \mathrm{C}$ NMR spectroscopy. From the ${ }^{1} \mathrm{H}$ NMR spectrum, a resonance integrating for 9 protons appears as a singlet at $0.14 \mathrm{ppm}$, which suggested the presence of the $-\mathrm{SiMe}_{3}$ group on the $\mathrm{O}$ atom. The two chemical shifts at 3.08 and $3.93 \mathrm{ppm}$ appeared as triplets and integrated for 2 protons each. The identity of the product, as a chloride salt, was confirmed by the presence of the broad shift at $9.43 \mathrm{ppm}$ integrating for 2 protons; a chemical shift which is indicative of the $-\mathrm{NH}_{2}$ group. ${ }^{61}$

With the in situ formation of $\mathbf{4}$, compound $\mathbf{3 k}$ was synthesized in only $12 \%$ after purification by the column chromatography. However, after the isolation of $\mathbf{4}$ and an optimization study was later performed by Jennifer Huynh ${ }^{60}$ and, of the reaction shown in Scheme 2.5, yields of up to $88 \%$ are achievable (Table 2.3). Compound 3k was successfully characterized by elemental analysis and ${ }^{1} \mathrm{H}$ and ${ }^{13} \mathrm{C}$ NMR spectroscopy. As in pincers $\mathbf{3 a - 3 j}$ an indicative $-\mathrm{NH}$ chemical shift was observed at $12.22 \mathrm{ppm}$ for $\mathbf{3 k}$ an upfield shift compared to the starting material (13.05 ppm; see Table 2.3). The close proximity of the alcohol group on the $\mathrm{N}$ atom to the amide proton could create the shielding effect, explaining the observed phenomena. 


\subsubsection{Synthesis of 3I: a carbene-pincer precursor}

1-Benzylimidazole ${ }^{62}$ was synthesized by reacting imidazole hydrochloride with benzyl bromide in the presence of $\mathrm{K}_{2} \mathrm{CO}_{3}$ in $\mathrm{MeCN}$. Pure compound was isolated in $42 \%$ yield as an off-white coloured waxy solid. ${ }^{1} \mathrm{H}$ NMR analysis of 1 -benzylimidazole agreed with the literature. ${ }^{62}$ The synthesis of NNC type pincer ligand, 3I, from 1-benzylimidazole and 2 in THF:MeCN (15.0:3.0 $\mathrm{mL}$ ratio) resulted in successful isolation of the desired product in $57 \%$ yield as a yellow wax (Scheme 2.6). The low solubility of 1 benzylimidazole in THF was resolved by the addition of a small amount of MeCN. The compound, 3I, was successfully analyzed by elemental analysis, ${ }^{1} \mathrm{H}$ and ${ }^{13} \mathrm{C}$ NMR spectroscopy. The resonance observed at $12.96 \mathrm{ppm}$ is representative of the $-\mathrm{NH}$ on the amide (Table 2.3). The proton appeared to be more deshielded in comparison to NNN pincers (3a-3k), which can be due to the absence of the hydrogen bonding or other interactions between the hydrogen on the amide and the imidazole moiety. Alternatively, 2I was synthesized from $\mathbf{2}$ as described in Scheme 2.6, as the precursor for 3l. However, the yield for the reaction to synthesize 2 I (56\%) did not introduce any benefits into increasing the overall yield for $\mathbf{3 l}$; hence it was not investigated further.

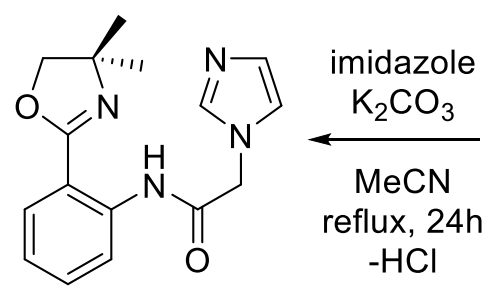

2l (56\%)

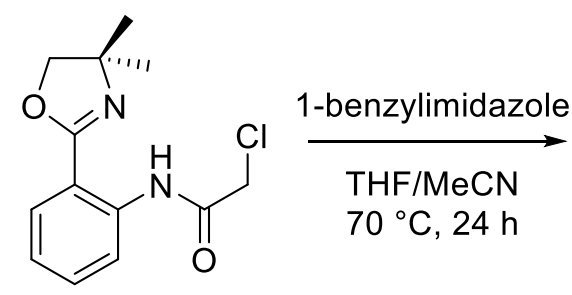

2

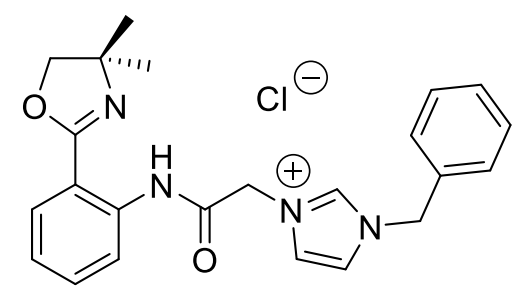

$3 \mathbf{I}(57 \%)$

Scheme 2.6 Synthesis of NNC pincer ligand $\mathbf{3 I}$ and a precursor $\mathbf{2 l}$. 


\subsubsection{Synthesis of $3 m$ and $3 m \cdot$ oxide}

The synthesis of NNP type pincer ligand, $\mathbf{3 m} \bullet$ oxide, was accomplished by reacting $\mathbf{2}$ with equimolar THF solution of potassium diphenylphosphide $\left(\mathrm{KPPh}_{2}\right)$ under nitrogen atmosphere for $24 \mathrm{~h}$ (Scheme 2.7).

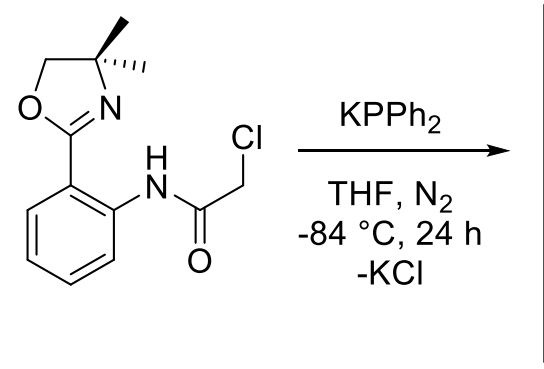

2<smiles>CC1COC(c2ccccc2NC(=O)CP(c2ccccc2)c2ccccc2)=N1</smiles>

$3 m$

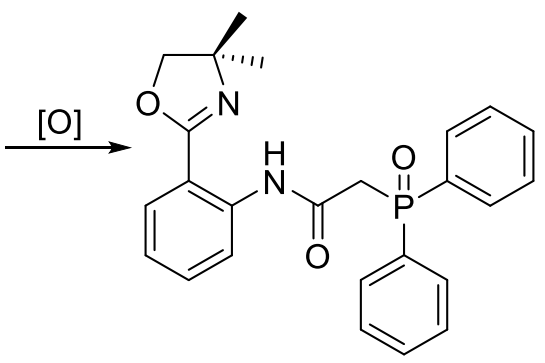

$3 \mathrm{~m}$ ? loxide $(55 \%)$

Scheme 2.7 Synthesis of NNP pincer ligand, 3m, from potassium diphenylphosphide.

The work-up of this reaction involved gravity filtration of the $\mathrm{KCl}$, formed as the by-product. By exposing the sample to air and moisture, $3 \mathrm{~m}$ is readily converted to $3 \mathrm{~m} \bullet$ oxide and was isolated in $55 \%$ yield (Table 2.3). This transition was monitored by ${ }^{31} \mathrm{P}$ NMR, where $3 \mathrm{~m}$ and $3 \mathrm{~m} \cdot$ oxide displaying chemical shifts at $-15.77 \mathrm{ppm}$ and $28.48 \mathrm{ppm}$, respectively. During the first experimental trial of this reaction, diphenylphosphine oxide $\left(\mathrm{O}=\mathrm{PPh}_{2} \mathrm{H} ; \mathrm{Ph}=\right.$ phenyl) and diphenylphosphine $\left(\mathrm{HPPh}_{2}\right)$ were both observed in the reaction mixture $\delta_{\mathrm{p}}=21.54 \mathrm{ppm}$ and $-40.39 \mathrm{ppm}$, respectively (Table 2.5 ). The literature values were in agreement within experimental error, with these observations. ${ }^{63-64}$

Table 2.5 Select literature and experimental ${ }^{31} \mathrm{P}$ NMR chemical shifts for PNN pincer.

\begin{tabular}{ccc}
\hline Compound & Lit. chemical shift (ppm) & Exp. chemical shift (ppm) \\
\hline $\mathrm{KPPh}_{2}$ & $-9.8^{65}$ & - \\
$\mathrm{HPPh}_{2}$ & $-42.1^{64}$ & -40.39 \\
$\mathbf{O =} \mathbf{P P h}_{2} \mathbf{H}$ & $21.9^{63}$ & 21.54 \\
$\mathbf{3 m}$ & - & -15.77 \\
$\mathbf{3 m} \cdot \mathbf{o x i d e}$ & - & 28.48 \\
\hline
\end{tabular}

Compound $3 \mathrm{~m} \cdot$ oxide was analyzed by X-ray crystallography (Figure 2.2) supporting the proposed structure and showcasing that there was no interaction between the 
hydrogen on the amide and the phosphorus in the solid state. Also, a molecule of water was coordinated to the oxygen on the phosphine oxide. $3 m \bullet$ oxide was also characterized by ${ }^{1} \mathrm{H}$ and ${ }^{13} \mathrm{C}$ NMR supporting the structure of the compound (see Table 2.3).

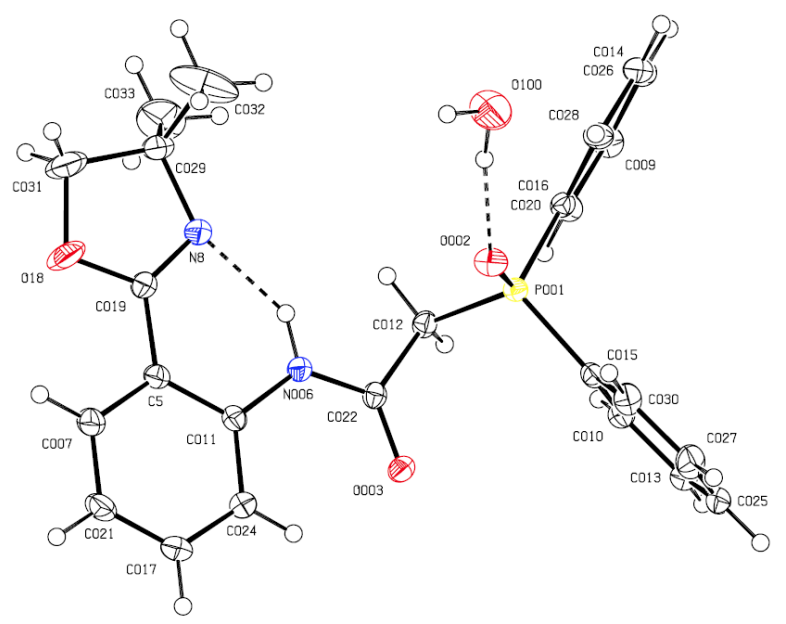

Figure 2.2 X-ray crystallographic structure of $3 m \bullet 0 x i d e$ (Solved by Laura R. Fernández).

\subsubsection{Synthesis of $3 n$}

An NNN pincer derivative from 1 and Boc-L-aspartic acid 4-benzyl ester was synthesized using 1.5 eq. DCC (a peptide coupling agent) in DCM (Scheme 2.8). Upon aqueous work-up the compound was obtained in $>99 \%$ yield as pale yellow wax. Elemental analysis and ${ }^{1} \mathrm{H}$ and ${ }^{13} \mathrm{C}$ NMR spectroscopy supported the compounds' identity. The interest into the development of this particular pincer is its unique applicability. Deprotecting the Boc and the benzyl groups on $\mathbf{3 n}$, deprotects the amine and carboxylic acid functional groups, which can then be covalently bonded to peptides. Combining this pincer ligand with peptides could yield interesting sensor-type molecules. 


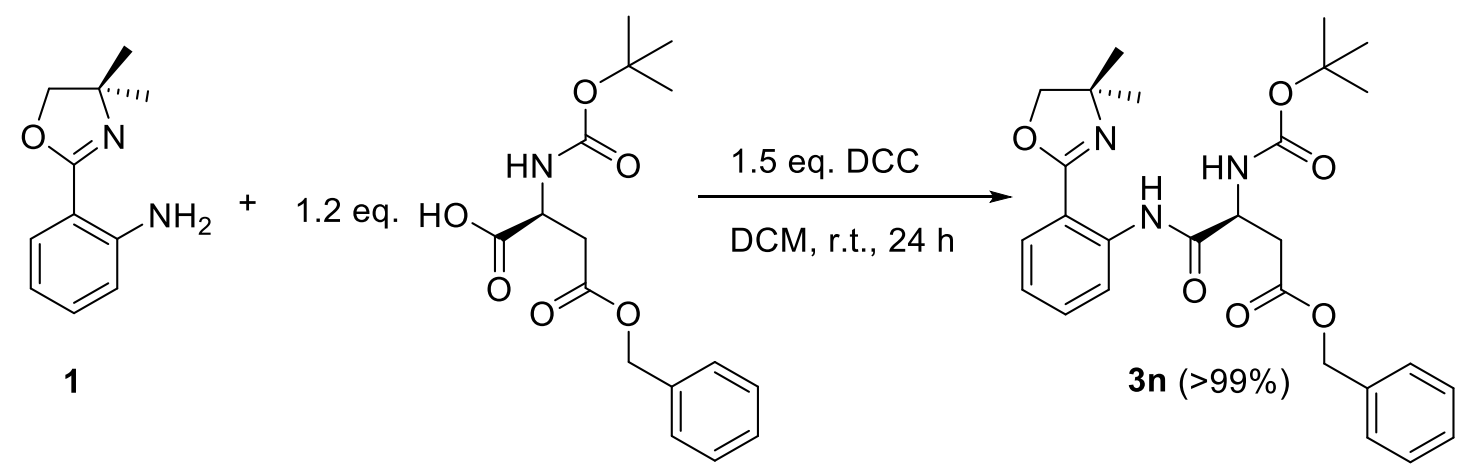

Scheme 2.8 Synthesis of $3 n$ from 1 .

\subsection{CHIRAL DERIVATIVES}

A chiral derivative of $\mathbf{2}$ was synthesized and isolated in $86 \%$ yield following the same procedure: from 2-chloroacetyl chloride and 5 (synthesized as per $\mathbf{1}^{49}$ ) in DCM (see Scheme 2.9). Peachy-coloured crystalline compound was analyzed by elemental analysis, x-ray crystallography and ${ }^{1} \mathrm{H}$ and ${ }^{13} \mathrm{C}$ NMR spectroscopy. Based on the orientation of the molecule (Figure 2.3), just as in the solid state of compound 2, it appeared that hydrogen bonding was observed for the amide hydrogen between both, the $\mathrm{N}$ on the oxazoline and the $\mathrm{Cl}$ on the chloromethyl group. From the crystal structure it was also determined that $\mathbf{6}$ exists as a single $R, S$ stereoisomer.

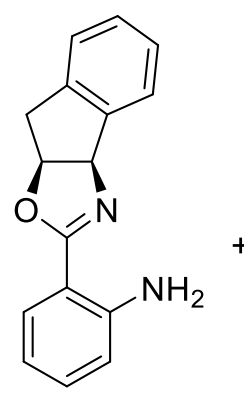

5

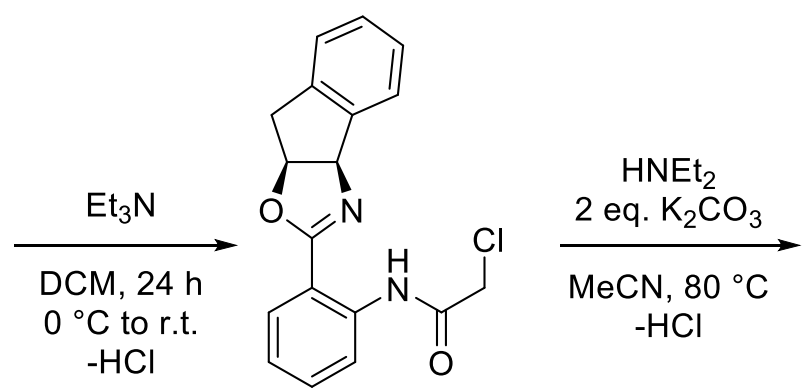

$6(86 \%)$<smiles>CCN(CC)CC(=O)Nc1ccccc1C1=N[C@H]2c3ccccc3C[C@H]2O1</smiles>

$7(55 \%)$

Scheme 2.9 Synthesis of the chiral derivatives, 6 and NNN type pincer ligand, 7.

The reaction of 6 with diethylamine in the presence of $\mathrm{K}_{2} \mathrm{CO}_{3}$ in $\mathrm{MeCN}$ yielded crude 7 in $55 \%$ yield, which was analyzed by ${ }^{1} \mathrm{H}$ NMR. Even after recrystallization, small 
amounts of starting material (6) were still observed; this suggests a slow decomposition of the product. A singlet observed at $12.54 \mathrm{ppm}$ was indicative of the proton on the amide (Table 2.3) and the $-\mathrm{CH}_{2}$ and $-\mathrm{CH}_{3}$ of the ethyl group on the amine were observed in the spectrum at $1.14 \mathrm{ppm}$ and $2.75 \mathrm{ppm}$ as triplet and quartet respectively, having matching $J$ values of $7.2 \mathrm{~Hz}$. These observations concluded that the product present in majority was indeed the desired chiral NNN pincer ligand.

Any attempt at functionalizing 6 with 1-benzylimidazole (as for $\mathbf{3 l}$ ) or $\mathrm{KPPh}_{2}$ (as for $\mathbf{3 m}$ ) to yield chiral NNC or NNP type pincer ended with unsuccessful results.

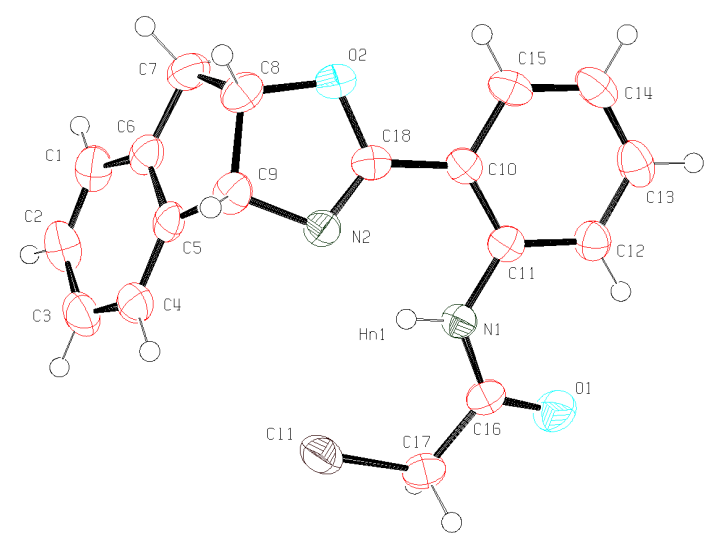

Figure 2.3 X-ray crystal structure of 6 (Solved by Robert A. Gossage). 


\section{CHAPTER 3 - COMPLEXES}

\subsection{PALLADIUM COMPLEXES}

\subsubsection{NNN type pincer complexes}

Complexation of NNN type pincer with Pd metal was accomplished using previously reported method of coordination as described by Decken et al. This uses a methanolic solution of $\mathrm{Li}_{2} \mathrm{PdCl}_{4}$, as Pd source, at RT (Scheme 3.1). ${ }^{41}$

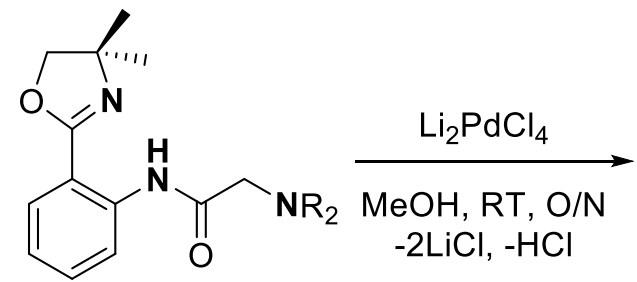

3a-e, 3g-k

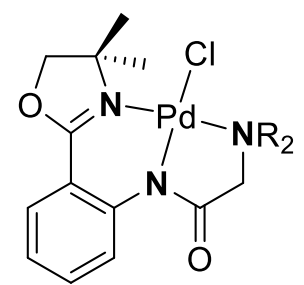

9a-e, 9g-k<smiles>CN1CC(=O)N2c3ccccc3C3=[N+](C)C(Cl)(Cl)[P@](C)(C1)N32</smiles>

$9 a(82 \%)$<smiles></smiles>

$9 d(80 \%)$<smiles>CCN1CC(=O)N2c3ccccc3C3=[N+](C)[P](Cl)(Cl)[C@]1(Cl)N32</smiles>

$9 \mathrm{~b}(52 \%)$

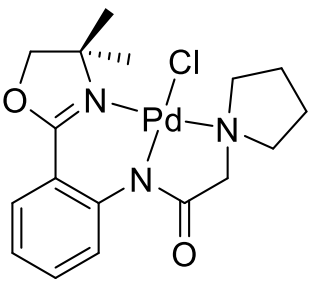

9 e $(62 \%)$

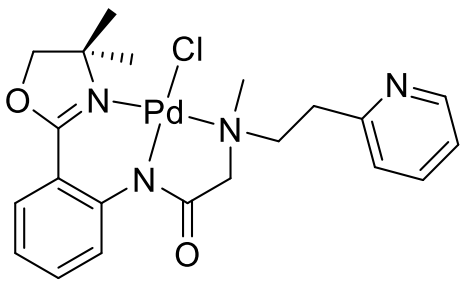

9c $(45 \%)$

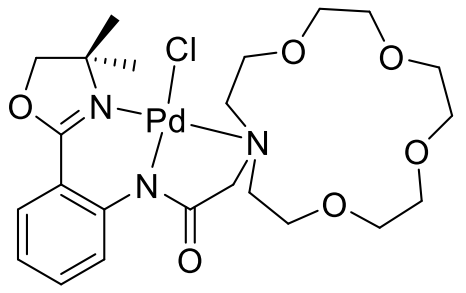

$9 g(93 \%)$<smiles>C=CCN1CC(=O)N2c3ccccc3C3=[N+](C2(Cl)Cl)[P@@]1(Cl)C[C@H]3C</smiles>

9h $(78 \%)$

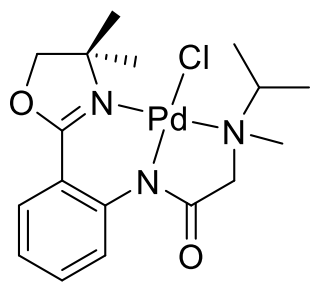

9i $(77 \%)$<smiles>C=CCN1CC(=O)N2c3ccccc3C3=[N+]([C@@]2(C)C1Cl)[P@@]3(Cl)CC=C</smiles>

9j $(42 \%)$

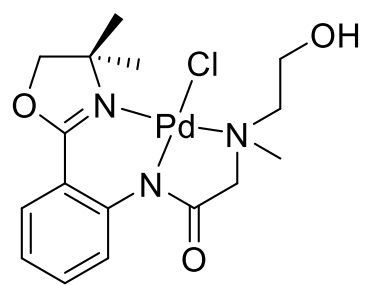

9k $(95 \%)$

Scheme 3.1 Synthesis of Pd-NNN pincer complexes, 9a-e and $\mathbf{9 g - k}$. 
A solution of $\mathrm{Li}_{2} \mathrm{PdCl}_{4}$ was prepared from stoichiometric amounts of $\mathrm{LiCl}$ and $\mathrm{PdCl}_{2}$ refluxed in $\mathrm{MeOH} ;{ }^{41}$ upon the dissolution of the starting materials the reaction was complete and the Pd precursor solution is ready to use. When $\mathrm{Li}_{2} \mathrm{PdCl}_{4}$ was added to a yellow coloured solution of an NNN pincer ligand (i.e. 9a-e or 9g-k) in $\mathrm{MeOH}$, the reaction solution turned bright orange in colour almost instantaneously. All resulting PdNNN complexes, aside from 9c, were purified by redissolving the compound in DCM and filtering the mixture (an orange solution with fine pale coloured precipitates) through a thick layer of Celite. In contrast, 9c was purified using preparative TLC (100\% acetone as eluent). All compounds were isolated as either waxy solids or powders, bright yellow to orange in colour, and isolated in yields ranging from $42 \%$ to $98 \%$.
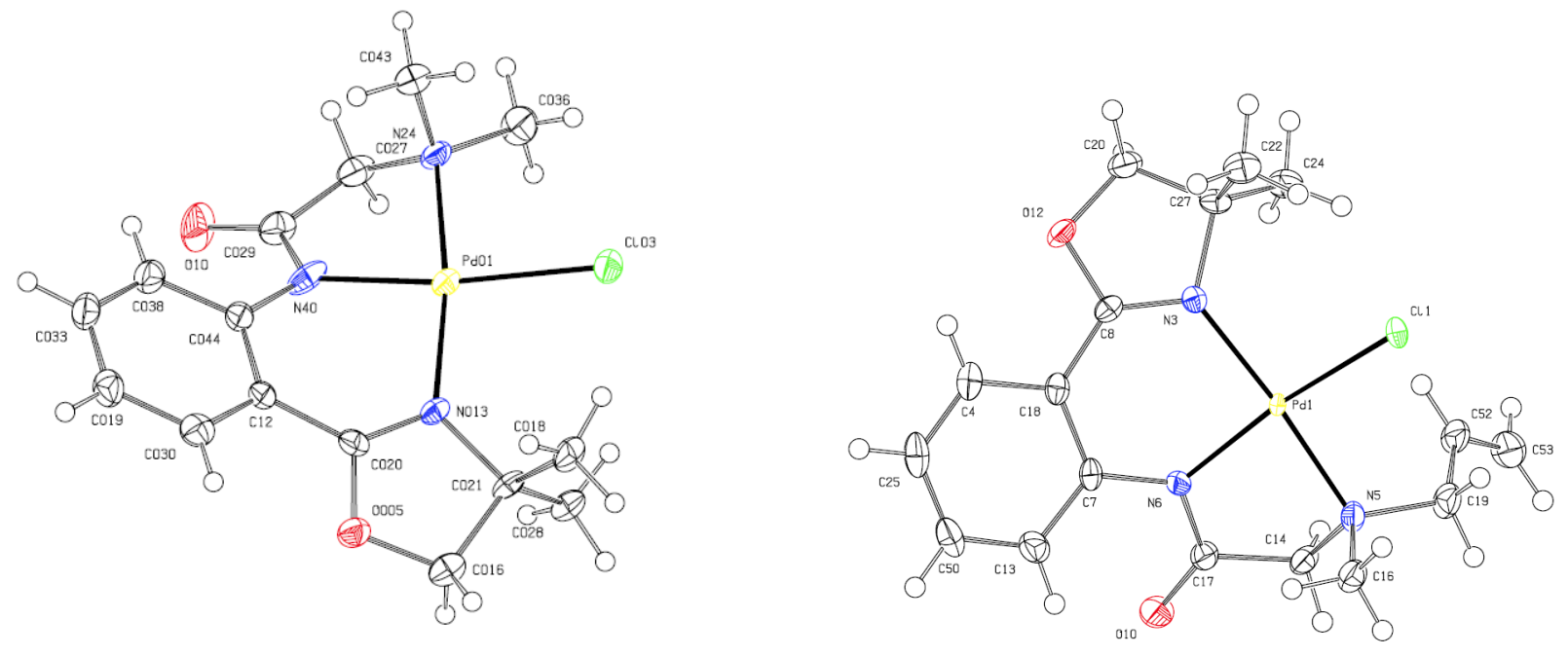

Figure 3.1 Crystal structures of $9 \mathrm{a}$ (left) and $9 \mathrm{~h}$ (right) solved by Laura R. Fernández.

Suitable crystals for the complexes $9 \mathrm{a}$ and $\mathbf{9 h}$ were grown to be analyzed by X-ray crystallography (Figure 3.1, left and right respectively). Both of the complexes showed a distorted square planar orientation of the ligated atoms around the metal centre. The Pd atom has a coordination number of 4 in both cases and an assigned oxidation state of +2 . The NNN pincer ligands indeed proved to behave as monoanionic ligands, being 
deprotonated at the amide position during the reaction, as shown previously for $\mathrm{Pd}$ complex with ligand $\mathbf{P} .{ }^{41}$ Aside from the X-ray crystallography analysis, all Pd-NNN complexes were characterized by elemental analysis and via ${ }^{1} \mathrm{H}$ and ${ }^{13} \mathrm{C}$ NMR spectroscopy. Proton chemical shifts for methyl and methylene functional groups moved downfield due to the electron withdrawing effect of the metal centre, upon complexation. ${ }^{66}$ The chemical shifts of the aromatic protons were not considerably affected by complexation. From ${ }^{13} \mathrm{C}$ NMR, all of the structures for Pd complexes, 9a-e and $\mathbf{9 g}-\mathbf{k}$, support a stoichiometry of $\mathrm{Pd}: \mathrm{NNN}: \mathrm{Cl}=1: 1: 1$. Note that one $\mathrm{H}$ has been lost from the free NNN ligand in all cases (Scheme 3.1).

\subsubsection{NNC type pincer complex}

Over the last decade $\mathrm{N}$-heterocyclic carbenes (NHCs) have shown promising results in catalysis and specifically in cross-coupling reactions. Hence, NHC-containing ligands have been studied extensively for the design and use of carbene containing catalysts. ${ }^{67-}$ ${ }^{69}$ The NHC ligand is considered a strong $\sigma$-donor and weak m-acceptor, which in turn improves the catalytic activity due to the increase in electron density on the metal centre. $^{70}$

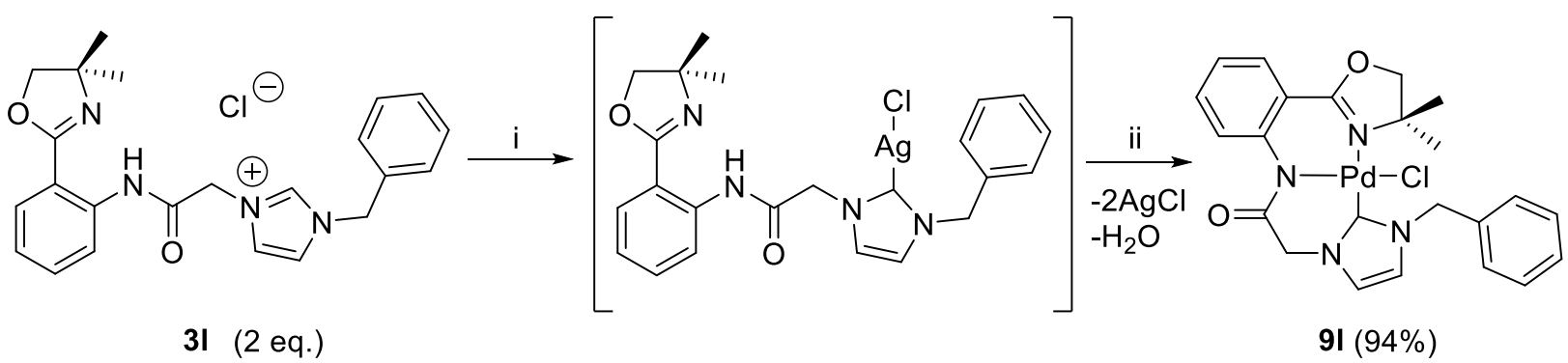

i) $\mathrm{Ag}_{2} \mathrm{O}, \mathrm{DCM}, \mathrm{RT}, 2 \mathrm{~h}$;

ii) $\mathrm{PdCl}_{2}(\mathrm{MeCN})_{2}, \mathrm{DCM}, \mathrm{RT}, \mathrm{O} / \mathrm{N}$

Scheme 3.2 Synthesis of Pd-NNC pincer complex, 91. 
A Pd-NNC complex was synthesized through Lin's method of transmetallation using silver $(\mathrm{I})$ oxide $\left(\mathrm{Ag}_{2} \mathrm{O}\right)$ as the transmetallating agent. ${ }^{69}$ Ligand $\mathbf{3 l}$ was stirred with $\mathrm{Ag}_{2} \mathrm{O}$ in $\mathrm{DCM}$ for $2 \mathrm{~h}$ and then the reaction mixture was filtered through Celite. Bis(acetonitrile)palladium(II) dichloride $\left(\mathrm{PdCl}_{2}(\mathrm{MeCN})_{2}\right)$ was added to the pale yellow filtrate, and the reaction solution turned bright yellow/orange within a few minutes, suggesting complexation (Scheme 3.2). Even though not isolated in this case due to its low stability, the syntheses of silver(I), gold(I) and copper(I) carbene intermediates have been previously reported. ${ }^{71-72}$ The protocols used here directly parallel those studies. ${ }^{69-}$ 72

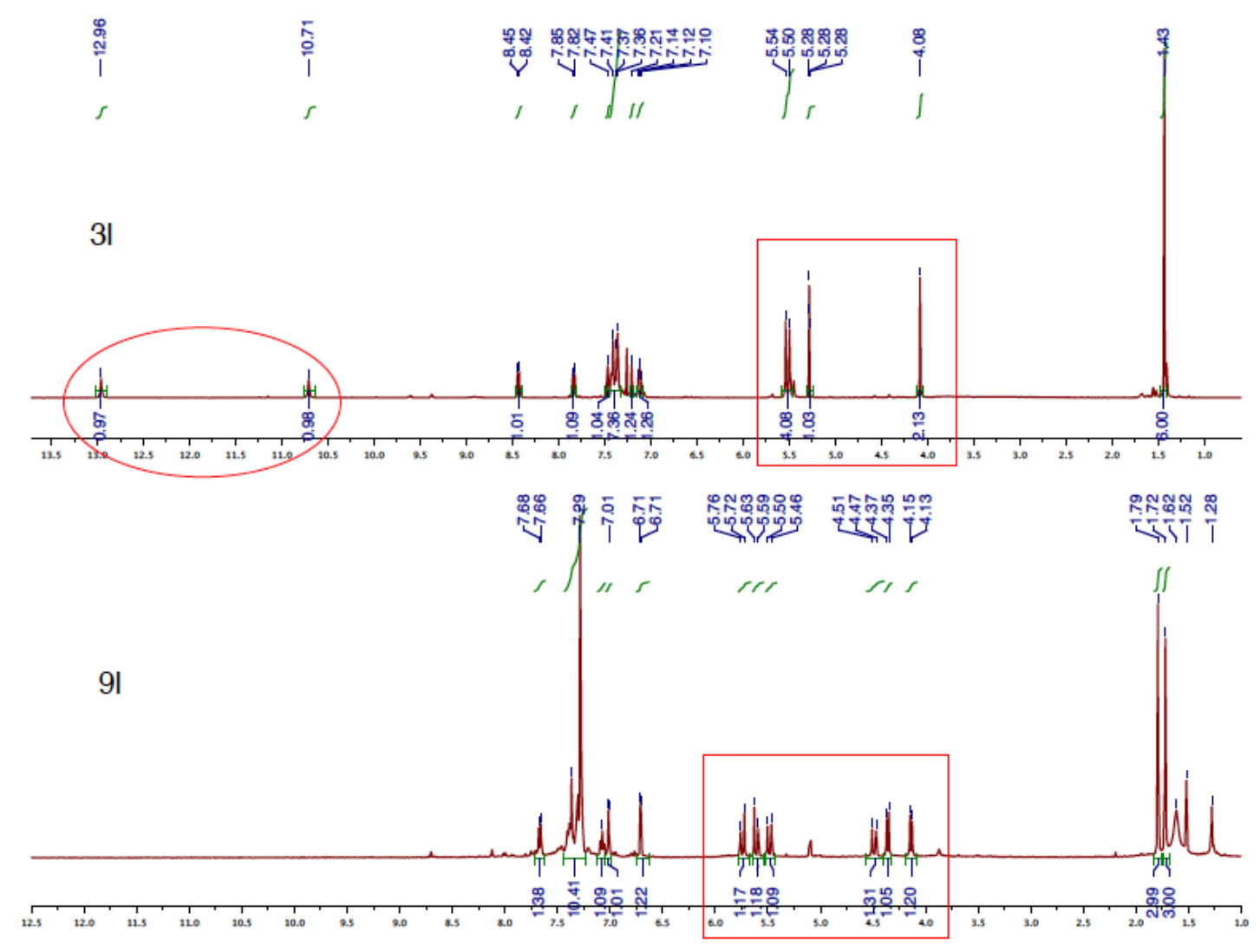

Figure 3.2 The comparison of the ${ }^{1} \mathrm{H}$ NMR spectra for $3 \mathbf{3}$ and 9 I.

The investigation into the coordination of complex 9l using ${ }^{1} \mathrm{H}$ NMR spectroscopy suggets that coordination of Pd to the carbene precursor did take place. This evidence 
includes the observed chemical shifts for the amide proton $(-\mathrm{NHC}=\mathrm{O})$ at $12.96 \mathrm{ppm}$ and the imidazole proton $\left(-\mathrm{NR}_{2} \mathrm{CHNR}_{2}{ }^{-}\right)$at $10.71 \mathrm{ppm}$ that are present for the carbene precursor (circled, Figure 3.2). Both of these resonances are absent for the isolated complex. The second order effect was also observed for all three methylene groups, which appeared as singlets at $4.08 \mathrm{ppm}, 5.50 \mathrm{ppm}$ and $5.54 \mathrm{ppm}$ on the ligand molecule, 3I. This suggests that those protons reside in different environments and are magnetically inequivalent (Figure 3.2).

\subsubsection{NNP type pincer complex}

Asymmetric pincer ligands containing soft donor atom, such as phosphorus, have also been of much interest with respect to catalysis applications for a wide variety of chemical transformations. ${ }^{73}$

A Pd-NNP pincer complex was therefore prepared in two steps. Due to the facile oxidation of $3 \mathrm{~m}$ to $3 \mathrm{~m} \bullet$ oxide, NNP pincer ligand $3 \mathrm{~m}$ was synthesized and used in situ following the procedure outlined in Section 2.2.1. The THF solution with $3 \mathrm{~m}$ was cannula transferred to a $\mathrm{MeCN}$ solution of $\mathrm{PdCl}_{2}(\mathrm{MeCN})_{2}$ and the resulting mixture stirred for $24 \mathrm{~h}$ (Scheme 3.3) at RT. After this time, the solution was gravity filtered and the solvent was then removed in vacuo. The crude sample of $9 \mathrm{~m}$ was retrieved in $96 \%$ yield, and appeared dark orange in colour.

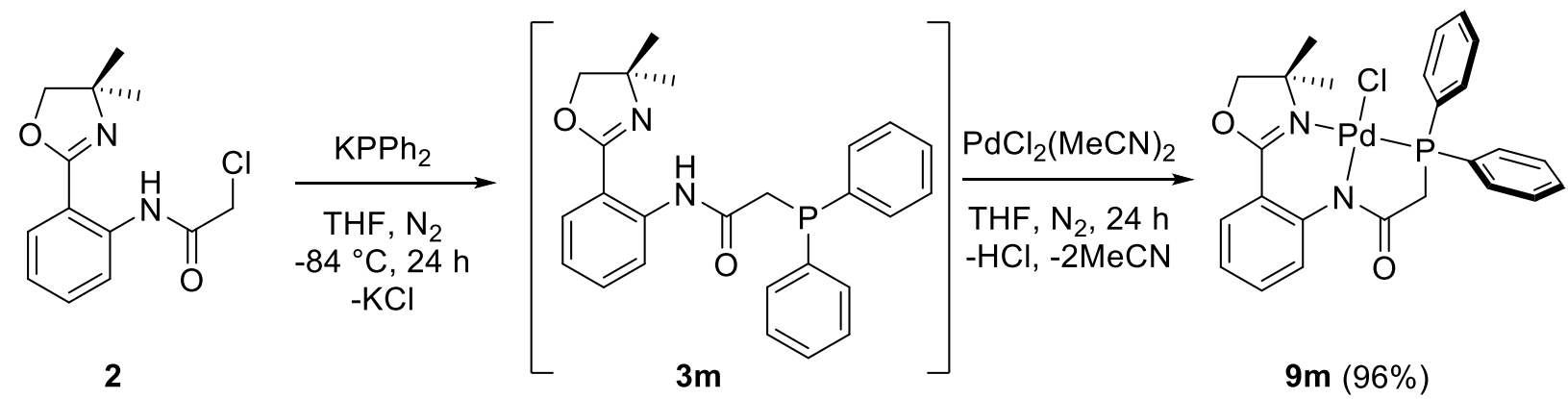

Scheme 3.3 Synthesis of Pd-NNP pincer complex, $9 m$ 
However, preparative TLC was used to further purify the compound for complete characterization (elemental analysis and ${ }^{1} \mathrm{H},{ }^{13} \mathrm{C}$ and ${ }^{31} \mathrm{P}$ NMR spectroscopy).

From the ${ }^{31} \mathrm{P}$ NMR spectrum, single resonance was observed with a chemical shift of $50.45 \mathrm{ppm}$, in contrast to the free ligand that was observed at $-15.77 \mathrm{ppm}$, suggesting only one phosphorus environment present.

3m.oxide
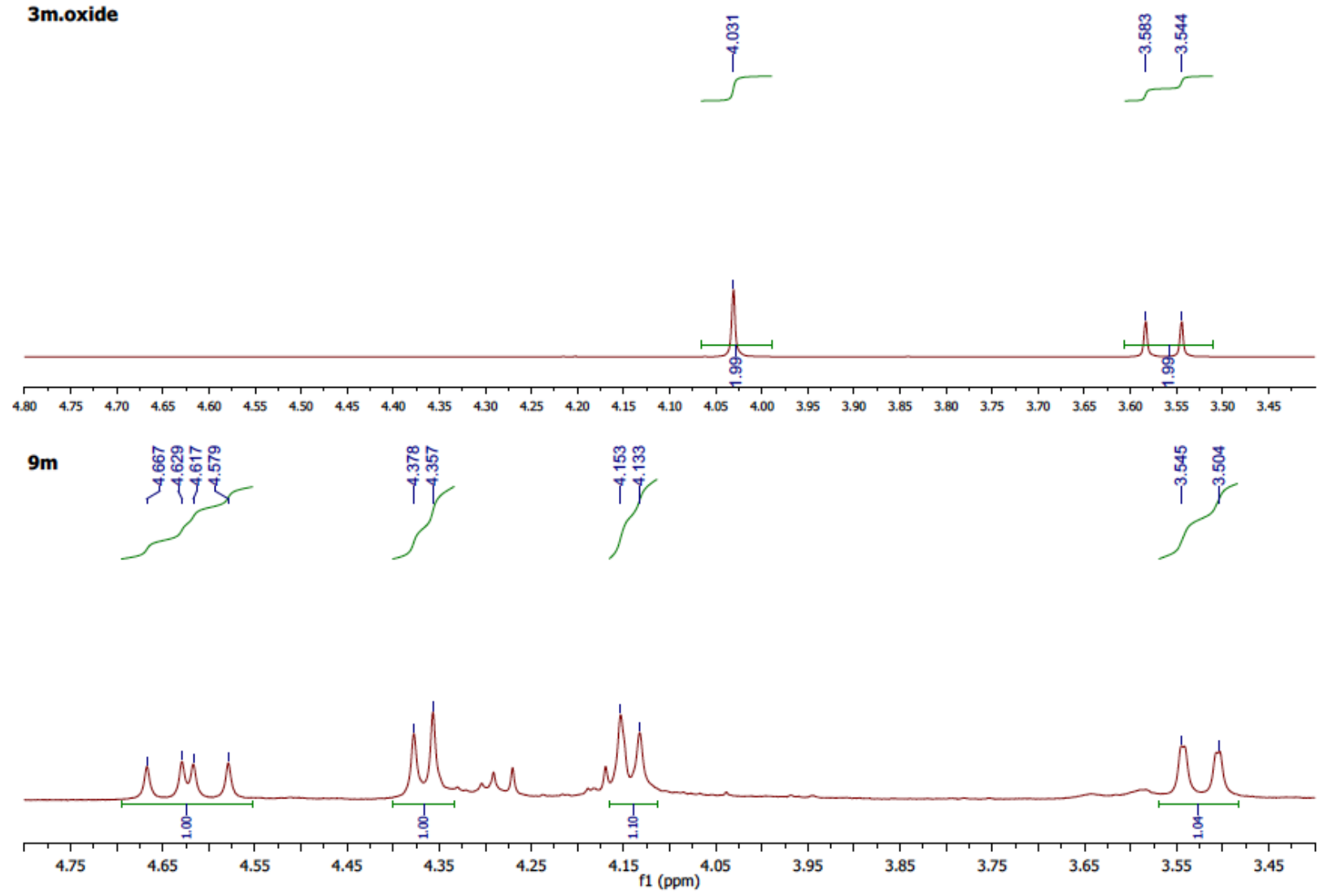

Figure 3.3 Select ${ }^{1} \mathrm{H}$ chemical shifts for $3 \mathrm{~m} \bullet$ oxide and $9 \mathrm{~m}$, depicting splitting effect. From the ${ }^{1} \mathrm{H}$ NMR spectrum, a second order effect for the methylene groups $\left(-\mathrm{CH}_{2^{-}}\right)$can be observed for $9 \mathrm{~m}$, where in comparison to $3 \mathrm{~m} \bullet$ oxide they were observed as singlet and a doublet (coupled to ${ }^{31} \mathrm{P}\left\{{ }^{1} \mathrm{H}\right\}, J=15.6 \mathrm{~Hz}$ ) (see Figure 3.3). 


\subsection{ATTEMPTS AT THE SYNTHESIS OF NICKEL COMPLEXES}

\subsubsection{NNN type pincer complexes}

Both academic and industrial research has witnessed an immense progress in the use of nickel complexes as catalysts in polymerization and cross-coupling type reactions. ${ }^{74-}$ ${ }^{75}$ For this reason, the investigation into employing NNN, NNC and NNP type pincer ligands, presented in this work, was performed in coordination chemistry with $\mathrm{Ni}$.

Gao and co-workers reported Ni-NNN pincer-like complexation using $\mathrm{NiCl}_{2} \bullet 6 \mathrm{H}_{2} \mathrm{O}$ in ethanol (with or without the base) or $\mathrm{NiCl}_{2}(\mathrm{DME})$ and lithium diisopropylamide (LDA) as the base in THF. ${ }^{74}$ However, following these reaction conditions with $\mathbf{3 e}$ pincer ligand did not yield any desired product. In fact, upon reaction work-up, which consisted of gravity filtration and $\mathrm{Et}_{2} \mathrm{O}$ wash, the resulted yellow waxy compound was found to be the free ligand (entries 1-4, Table 3.1). Peters and coworkers reported coordination of their monoanionic $\mathrm{NNN}$ type pincers with $\mathrm{Ni}$ through $\mathrm{NiCl}_{2}(\mathrm{DME})$ precursor in the presence of $\mathrm{Et}_{3} \mathrm{~N}$ in THF. ${ }^{75}$ Entry 5 (Table 3.1) depicts the unsuccessful trial with $3 \mathrm{e}$ pincer ligand.

Table 3.1 Synthesis of Ni-NNN type pincer complex from 3e ligand.

\begin{tabular}{|c|c|c|c|c|c|}
\hline Entry & {$[\mathrm{Ni}]$} & Solvent & Base & Time & Temperature/Atmosphere \\
\hline 1 & $\mathrm{NiCl}_{2} \cdot 6 \mathrm{H}_{2} \mathrm{O}$ & $\mathrm{EtOH}$ & - & $12 \mathrm{~h}$ & RT/air \\
\hline 2 & $\mathrm{NiCl}_{2} \cdot 6 \mathrm{H}_{2} \mathrm{O}$ & $\mathrm{EtOH}$ & ${ }^{t} \mathrm{BuOK}$ & $12 \mathrm{~h}$ & RT/air \\
\hline 2 & $\mathrm{NiCl}_{2} \mathrm{DME}$ & THF & LDA & $\mathrm{O} / \mathrm{N}$ & $\mathrm{RT} / \mathrm{N}_{2}$ \\
\hline 3 & $\mathrm{NiCl}_{2} \mathrm{DME}$ & THF & LDA & $18 \mathrm{~h}$ & $\mathrm{RT} / \mathrm{N}_{2}$ \\
\hline 5 & $\mathrm{NiCl}_{2} \mathrm{DME}$ & THF & $\mathrm{Et}_{3} \mathrm{~N}$ & $19 \mathrm{~h}$ & $60^{\circ} \mathrm{C} / \mathrm{N}_{2}$ \\
\hline
\end{tabular}


The theorized molecular geometry of the diamagnetic Ni-NNN pincer complex was square planar, the colour of which had to be red. However, the reaction solutions for all of the trials (Table 3.1) did not change the colour in the course of the reaction and remained green.

\subsubsection{NNC type pincer complex}

The synthetic route for Ni-NNC pincer complex was employed from the synthesis of 9l, through Lin's method of transmetallation using silver $(\mathrm{I})$ oxide $\left(\mathrm{Ag}_{2} \mathrm{O}\right)$ as the transmetallating agent. ${ }^{69}$ Ligand $3 \mathbf{l}$ was stirred with $\mathrm{Ag}_{2} \mathrm{O}$ in DCM for $2 \mathrm{~h}$ and then the reaction mixture was filtered through Celite. Bis(triphenylphosphine)nickel(II) dichloride $\left(\mathrm{NiCl}_{2}\left(\mathrm{PPh}_{3}\right)_{2}\right)$ was added to the pale yellow filtrate, and the reaction solution turned dark green instantaneously (Scheme 3.4). Unfortunately, this trial was unsuccessful in producing a Ni-NNC complex, once again yielding light yellow wax - characterized as the free ligand.

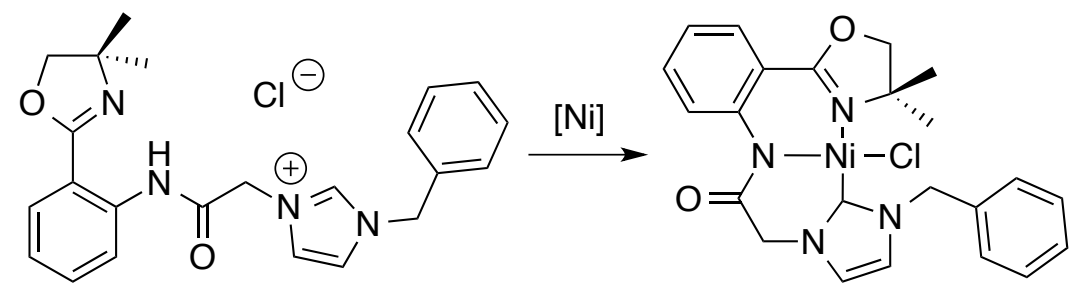

Scheme 3.4 Synthesis of Ni-NNC type pincer complex from 3I ligand.

\subsubsection{NNP type pincer complex}

A trial reaction, investigating the synthesis of Ni-NNP complex from $3 \mathrm{~m}$ and $\mathrm{NiCl}_{2} \mathrm{DME}$ precursor in the presence of $n$-BuLi (to deprotonate the amide hydrogen), was followed from the reaction conditions reported by Liu and co-workers (Scheme 3.4) ${ }^{76}$ First, 3m was treated with $n$-BuLi and then this solution was added to the suspension of 
$\mathrm{NiCl}_{2} \mathrm{DME}$ in THF. The colour of the reaction solution was pale green, and after solvent evaporation, blue waxy compound resulted in having minimal solubility in $\mathrm{CDCl}_{3}$ or benzene- $d_{6}$. Unfortunately, as previously shown with NNN and NNC type ligands, the complexation and characterization with NNP ligand was also unsuccessful. In contrast to $\mathrm{Pd}-\mathrm{Ni}$ chemistry appeared to be more air/water sensitive and if the paramagnetic complexes are formed - the characterization by $\mathrm{x}$-ray crystallography is required.

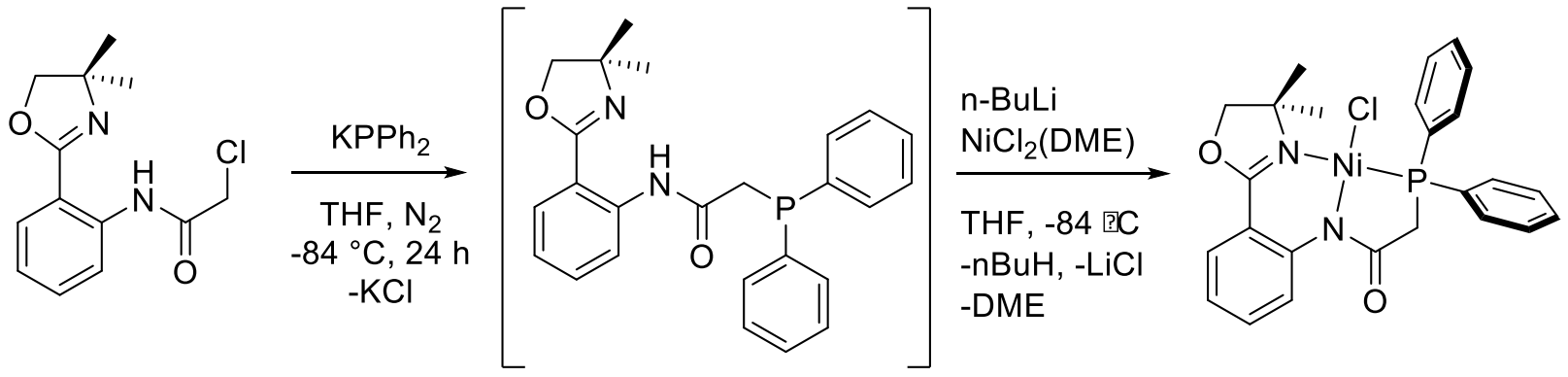

Scheme 3.5 Synthesis of Ni-NNP pincer complex from 3m ligand.

Due to these presumed stability issues and time constraints, further Ni chemistry in this regard was abandoned. 


\section{CHAPTER 4 - CATALYSIS}

\subsection{ALLYLATION OF ALDEHYDES}

Allylic substitution reactions catalyzed by palladium complexes have become an important set of transformations in modern organic chemistry. ${ }^{77-81}$ The first series of reports on allylation of aldehydes and imines catalyzed by bis(allyl)palladium species was published by Yamamoto and coworkers in 1996, where the allyltributyltin was the source of the allyl group. ${ }^{82}$ However, there are two inherent drawbacks with using bis(allyl) complexes. First, the difficulty in controlling the regioselectivity when the two allylic group have different substituents (Scheme 4.1). And secondly, allyl-allyl coupling can occur before the reaction with a desired electrophile.

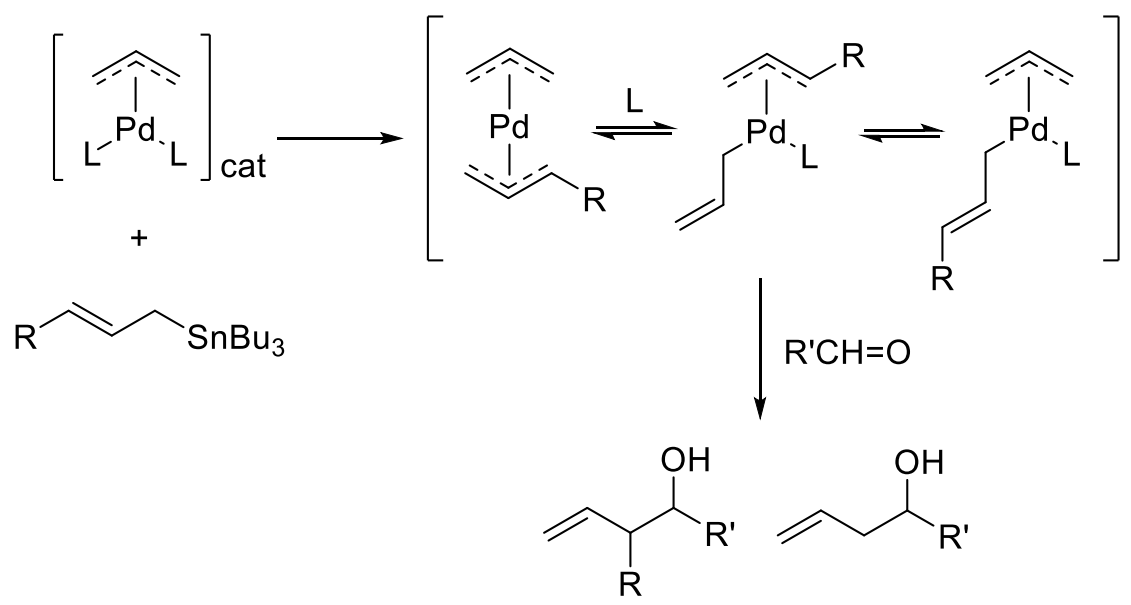

Scheme 4.1 Bis(allyl)palladium in catalysis. ${ }^{78}$

Szabó and co-workers theorized using palladium pincer complexes for the allylation of electrophiles, and the monodentate anionic ligand would undergo transmetallation. The pincer ligand to metal bond (that is trans to the Pd-allyl bond) would enhance the nucleophilicity of the allyl fragment. ${ }^{83}$ So far, the application of the carbon electrophiles in these types of reactions remains unexplored. ${ }^{84}$ 
Palladium pincer complexes have been considered to be attractive complexes in catalytic applications. Some of the features supporting that argument include: 1) their stability, even during a catalytic transformation the pincer ligand remains tightly bound to the metal centre for the entire duration of the reaction; 2) due to the strong coordination of the pincer, there is only one coordination site, trans to the anionic atom, providing restriction with respect to catalytic sites on palladium; 3) Oxidation state of palladium in pincer complexes is +2 under ambient conditions, upon reduction of the metal atom - ligand dissociates from the metal. Hence, the oxidation state of +4 is attainable but only under elevated temperatures (over $120^{\circ} \mathrm{C}$ ). ${ }^{78,85}$

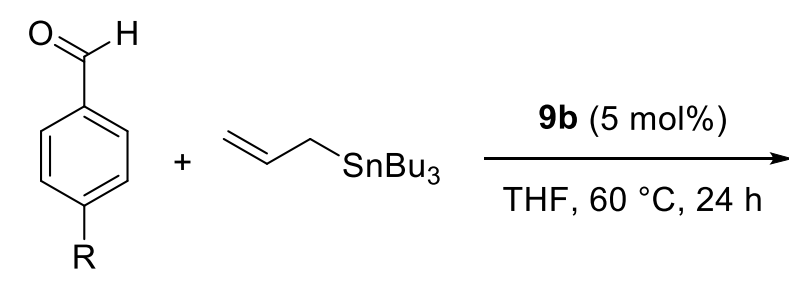

10a: $R=\mathrm{NO}_{2}$
10b: $R=\mathrm{OCH}_{3}$
10c: $R=\mathrm{H}$

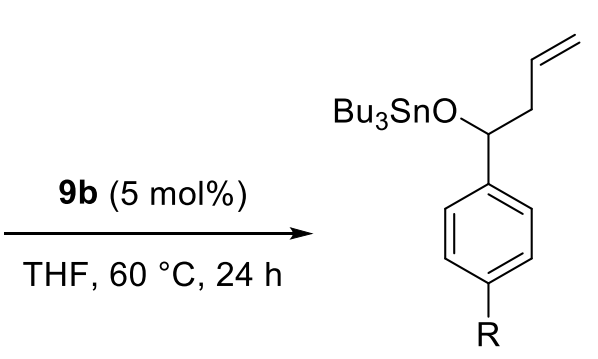

Scheme 4.2 Allylation of para-substituted benzaldehydes catalyzed by $9 \mathrm{~b}$.

A preliminary study into the allylation reaction was studied with three para-substituted benzaldehydes (10a-c) and allyltributyltin (as the allyl group source) catalyzed by previously described Pd-NNN pincer complex, 9b. To each of the aldehydes, a solution of $\mathbf{9 b}$ in THF was added following the addition of 1.2 equiv. of allyltributyltin. The reaction solution was stirred in air at $60{ }^{\circ} \mathrm{C}$. After $24 \mathrm{~h}$ the reaction solution still appeared yellow in colour (suggesting no catalyst decomposition) and the solvent was allowed to evaporate. The resulting yellow waxy compounds were characterized using ${ }^{1} \mathrm{H}$ NMR spectroscopy to determine the \% conversion (see Table 4.1 and Figure A62). 
Both benzaldehyde and $p$-nitrobenzaldehyde showed high conversion to the desired product (entries 1 and 5, Table 4.1) with the aldehyde peak not present. $p$ Methoxybenzaldehyde was converted in $76 \%$ (entry 3, Table 4.1). However, even though an unreacted aldehyde was observed in the spectrum, there was no unreacted allyltributyltin compound present. This could be due to an error in the amounts of the reagents added when the reaction was set-up.

Table 4.1 Pd-NNN pincer complex-catalyzed allylation of select aldehydes.

\begin{tabular}{cccc}
\cline { 2 - 4 } & Entry & $\mathbf{R}$ & Yield (\%) \\
\cline { 2 - 4 } & $\mathrm{NO}_{2}$ & 99 \\
$2^{\mathrm{b}}$ & $\mathrm{NO}_{2}$ & 0 \\
3 & $\mathrm{OCH}_{3}$ & 76 \\
$4^{\mathrm{b}}$ & $\mathrm{OCH}_{3}$ & 0 \\
5 & $\mathrm{H}$ & 99 \\
& $6^{\mathrm{b}}$ & $\mathrm{H}$ & 0 \\
\cline { 2 - 3 } & \\
a not isolated yields (determined from $\left.{ }^{1} \mathrm{H} \mathrm{NMR}\right)$ & b
\end{tabular}

As stated previously, the reaction studied in Scheme $\mathbf{4 . 2}$ has been of a preliminary interest. So far in literature, only Pd pincer complexes with symmetric PCP type ligands have shown progress in these types of catalytic transformations. ${ }^{86}$ Herein we demonstrated asymmetric Pd-NNN type pincer complex as a successful catalyst. Table 4.2 outlines the chemical shifts for the allylation of aldehydes reaction. It should be noted that no acidic work-up or product isolation took place.

Table 4.2 Comparison of ${ }^{1} \mathrm{H}$ NMR chemical shifts for aldehyde allylation reaction.

\begin{tabular}{cc|cc|cc}
\hline $\mathbf{1 0 a}$ & $\mathbf{1 1 a}$ & $\mathbf{1 0 b}$ & $\mathbf{1 1 b}$ & $\mathbf{1 0 c}$ & $\mathbf{1 1 c}$ \\
\hline 10.16 & - & 9.91 & - & 10.02 & - \\
8.39 & 8.22 & 7.86 & 7.28 & 7.87 & \\
8.07 & 7.55 & 7.02 & 6.88 & 7.61 & $7.50-7.25$ \\
\cline { 1 - 1 } AllylSnBu $_{3}$ & & 3.91 & 3.81 & 7.51 & \\
5.95 & \multirow{2}{*}{5.80} & AllylSnBu & & AllylSnBu & \\
4.79 & 5.19 & 5.95 & 5.80 & 5.95 & 5.82 \\
4.65 & 4.88 & 4.79 & 5.13 & 4.79 & 5.14 \\
1.79 & 2.53 & 4.65 & 4.69 & 4.65 & 4.74 \\
& & 1.79 & 2.50 & 1.79 & 2.52 \\
\hline
\end{tabular}




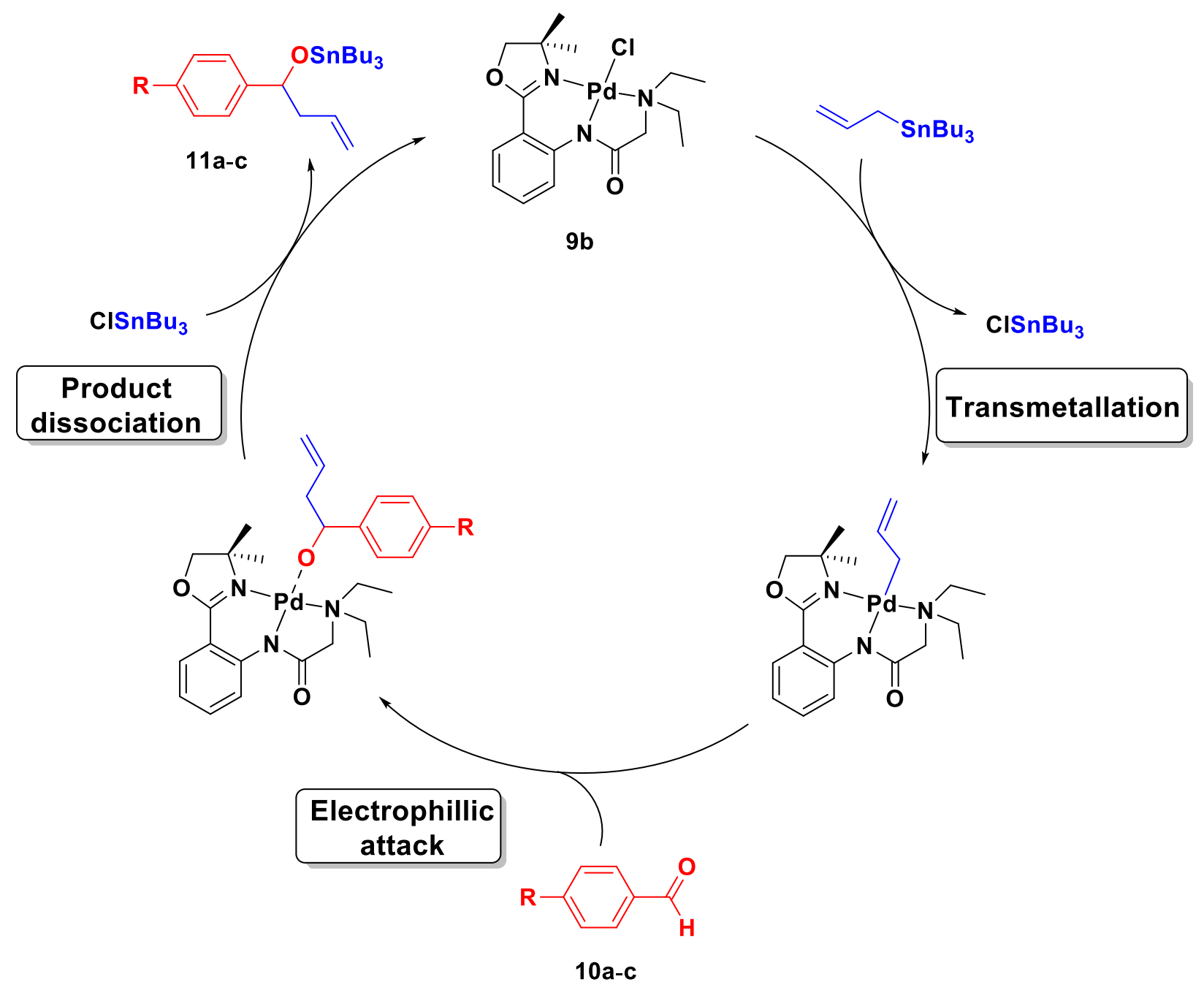

Scheme 4.3 A proposed mechanism for the allylation of aldehydes.

DFT calculations, ${ }^{86}$ show that the mechanism of this catalytic process involves transmetallation step to happen first on a relatively electron poor palladium centre. The electrophilic attack happens at the y-position of the allyl group in the second step. This is driven by electronic (not steric) factors. And as the final step, product dissociation and catalyst regeneration happens. Importantly, no change in oxidation state of palladium takes place during the three steps of the catalytic process (Scheme 4.3). 


\section{CHAPTER 5 - EXPERIMENTAL}

\subsection{GENERAL}

All reactions were carried out under ambient atmosphere conditions unless otherwise stated. All chemicals were purchased commercially. All of the reagents were used without further purification. Solvents used for reactions were supplied by an mBraun Solvent Purification System (SPS) or in commercial bottles (Aldrich), none of which were further purified. Compounds $\mathbf{1}$ and $\mathbf{5}$ were synthesized according to literature ${ }^{49}$. NMR experiments were recorded on a Bruker Avance II 400 using $\mathrm{CDCl}_{3}$ (chloroform$\left.\mathrm{d}_{1}\right)$ at $400 \mathrm{MHz}\left({ }^{1} \mathrm{H}\right), 162 \mathrm{MHz}\left({ }^{31} \mathrm{P}\right)$ and $100 \mathrm{MHz}\left({ }^{13} \mathrm{C}\right)$ at $\mathrm{RT}$. In all spectra, chemical shifts were adjusted to the solvent peak (7.26 ppm for $\mathrm{CHCl}_{3}$ for ${ }^{1} \mathrm{H}$ and $77.16 \mathrm{ppm}$ for $\mathrm{CDCl}_{3}$ for ${ }^{13} \mathrm{C}$ ). Melting points were determined using Fisher Scientific melting point apparatus with the maximum temperature of $300{ }^{\circ} \mathrm{C}$. The values provided for melting point are uncorrected. IR spectra were obtained on Perkin Elmer Spectrum One using $\mathrm{KBr}$ disks for solid compounds and $\mathrm{NaCl}$ disks for liquid/oil compounds. SiliCycle Thin Layer Chromatography (TLC) plates (thickness: $250 \mu \mathrm{m}$ ) were used for TLC characterization; visualization was obtained under UV light irridiation. Some of the products (as specified) were purified by dry-column flash chromatography (DCFC). The general procedure included the sample being adsorbed onto silica $(\sim 3 \mathrm{~g})$ followed by rotary evaporation. Then, a $100 \mathrm{~mL}$ sintered glass funnel was packed with clean silica $(\sim 12 \mathrm{~g})$ and then topped with the compound-adsorbed silica sample. Fractions were collected individually by applying vacuum. Each fraction consisted of total $25 \mathrm{~mL}$ of the solvent mixture, starting from $25 \mathrm{~mL}$ of hexanes and increasing the polarity by adding 1 $\mathrm{mL}$ of EtOAc with each consecutive fraction (e.g. fraction \#2: $24 \mathrm{~mL}$ of hexanes and 1 
$\mathrm{mL}$ of EtOAc). Theoretical calculations were performed on Spartan'10 at B3LYP: 6$311++G^{* *}$ level of theory.

\subsection{LIGANDS}

\section{2-Chloro-N-(2-(4,4-dimethyl-4,5-dihydrooxazol-2-yl)phenyl)acetamide (2)}

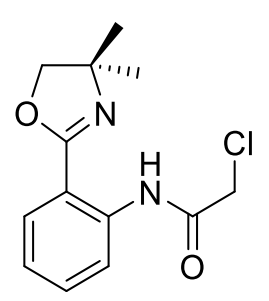

Molecular weight: $266.72 \mathrm{~g} \mathrm{~mol}^{-1}$

The solution of $1(1.70 \mathrm{~g}, 8.90 \mathrm{mmol})$ and triethylamine $(1.86 \mathrm{~mL}, 13.3 \mathrm{mmol})$ in DCM (25 mL) was placed into an ice bath and stirred for $15 \mathrm{~min}$. 2-Chloroacetyl chloride (0.78 $\mathrm{mL}, 9.8 \mathrm{mmol}$ ) was then added dropwise over the period of $5 \mathrm{~min}$ to the stirring solution. Upon the completion of addition, the contents of the reaction vessel were stirred for $2 \mathrm{~h}$ at RT. Over that period of time, the colour of the solution changed from yellow to orange and finally to deep red; a pale pink precipitate was also noted. After $2 \mathrm{~h}$, the dark red solution was gravity filtered and the filtrate was left to evaporate overnight (fumehood). Dark brown crystals formed and were then washed with $\mathrm{Et}_{2} \mathrm{O}(20 \mathrm{~mL})$, resulting in an orange solution and a black-coloured precipitate. The mixture was gravity filtered. Following solvent removal the product was isolated as orange crystalline solid $(2.02 \mathrm{~g}$, 85\% yield; pure): $M p 97-99^{\circ} \mathrm{C} ; \mathrm{R}_{f}=0.62$ (hexanes-EtOAc, 4:1).

IR (KBr): 2953, 1675, 1639, 1609, 1589, 1535, 1450, 1355, 1303, 1057, 1046, 959, 776, $690 \mathrm{~cm}^{-1}$. 
${ }^{1} \mathrm{H}$ NMR $\left(400 \mathrm{MHz}, \mathrm{CDCl}_{3}\right): \delta=13.05(\mathrm{~s}, 1 \mathrm{H}), 8.74(\mathrm{dd}, J=1.2 \mathrm{~Hz}, J=8.8 \mathrm{~Hz}, 1 \mathrm{H})$, 7.85 (ddd, $J=0.4 \mathrm{~Hz}, J=2.0 \mathrm{~Hz}, J=8.0 \mathrm{~Hz}, 1 \mathrm{H}$ ), 7.47 (dddd, $J=0.4 \mathrm{~Hz}, J=2.0 \mathrm{~Hz}, J$ $=7.6 \mathrm{~Hz}, J=8.8 \mathrm{~Hz}, 1 \mathrm{H}), 7.13(\mathrm{ddd}, J=1.2 \mathrm{~Hz}, J=7.6 \mathrm{~Hz}, J=8.0 \mathrm{~Hz}, 1 \mathrm{H}), 4.21(\mathrm{~s}, 2$ H), 4.07 (s, $2 \mathrm{H}), 1.41(\mathrm{~s}, 6 \mathrm{H})$.

${ }^{13} \mathrm{C}$ NMR $\left(100 \mathrm{MHz}, \mathrm{CDCl}_{3}\right): \delta=165.9,161.6,139.2,132.4,129.1,123.3,120.0,114.5$ $78.1,68.2,43.7,28.6$.

Anal. Calcd for $\mathrm{C}_{13} \mathrm{H}_{15} \mathrm{CIN}_{2} \mathrm{O}_{2}$ : C, 58.54; $\mathrm{H}, 5.67 ; \mathrm{N}, 10.50 \%$. Found: $\mathrm{C}, 58.40 ; \mathrm{H}, 5.55$; $\mathrm{N}, 10.44 \%$.

\section{$\mathrm{N}$-(2-(4,4-Dimethyl-4,5-dihydrooxazol-2-yl)phenyl)-2-(dimethylamino)acetamide} (3a)

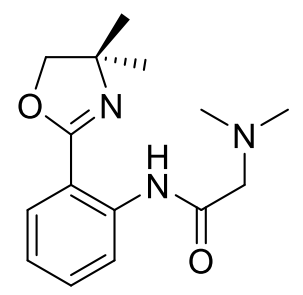

\section{Molecular weight: $275.35 \mathrm{~g} \mathrm{~mol}^{-1}$}

Thionyl chloride $(8.81 \mathrm{~mL}, 121 \mathrm{mmol})$ was added to $\mathrm{N}, \mathrm{N}$-dimethylglycine $(0.50 \mathrm{~g}, 4.85$ $\mathrm{mmol}$ ) in a $50 \mathrm{~mL}$ round-bottom flask. The orange-coloured mixture was heated to $50^{\circ} \mathrm{C}$ and stirred for $4 \mathrm{~h}$ (until the solid disappeared). Excess thionyl chloride was removed in vacuo from the clear, bright yellow solution resulting in bright yellow solid. Then, the solution of $1(0.46 \mathrm{~g}, 2.42 \mathrm{mmol})$ and triethylamine $(0.70 \mathrm{~mL}, 5.02 \mathrm{mmol})$ in DCM $(25.0$ $\mathrm{mL}$ ) was added to the in situ prepared acyl chloride and stirred for $12 \mathrm{~h}$ at RT. The dark orange solution was then extracted with water $(3 \times 50 \mathrm{~mL})$. The combined organic layers were dried over $\mathrm{MgSO}_{4}$ and gravity filtered, resulting in a transparent brownish-orange solution. After evaporation of the solvent, beige solid was formed. The compound was 
purified by DCFC and the product was collected as dark orange wax from fractions 5 to 14 (0.34 g, 47\% yield, pure): $R_{f}=0.58$ (hexanes-EtOAc, 4:1).

IR (KBr): 2969, 2779, 1677, 1645, 1581, 1532, 1447, 1291, 1208, 1053, 1044, 963, 877 $753,689 \mathrm{~cm}^{-1}$.

${ }^{1} \mathrm{H}$ NMR $\left(400 \mathrm{MHz}, \mathrm{CDCl}_{3}\right): \delta=12.80(\mathrm{~s}, 1 \mathrm{H}), 8.84(\mathrm{~d}, J=12.0 \mathrm{~Hz}, 1 \mathrm{H}), 7.83(\mathrm{dd}, J=$ $8.0 \mathrm{~Hz}, J=4.0 \mathrm{~Hz}, 1 \mathrm{H}), 7.44(\mathrm{t}, J=8.0 \mathrm{~Hz}, 1 \mathrm{H}), 7.07(\mathrm{t}, J=8.0 \mathrm{~Hz}, 1 \mathrm{H}), 4.05(\mathrm{~s}, 2 \mathrm{H})$, $3.16(\mathrm{~s}, 2 \mathrm{H}), 2.39$ (s, $6 \mathrm{H}), 1.40(\mathrm{~s}, 6 \mathrm{H})$.

${ }^{13} \mathrm{C} \mathrm{NMR}\left(100 \mathrm{MHz}, \mathrm{CDCl}_{3}\right): \delta=171.0,161.1,139.5,132.2,129.0,122.3,119.8,114.1$, $77.7,68.1,64.5,46.0,28.6$.

Anal. Calcd for $\mathrm{C}_{15} \mathrm{H}_{21} \mathrm{~N}_{3} \mathrm{O}_{2}$ : C, 65.43; $\mathrm{H}, 7.69 ; \mathrm{N}, 15.26 \%$. Found: $\mathrm{C}, 64.88 ; \mathrm{H}, 7.66 ; \mathrm{N}$, $15.00 \%$.

2-(Diethylamino)-N-(2-(4,4-dimethyl-4,5-dihydrooxazol-2-yl)phenyl)acetamide (3b)

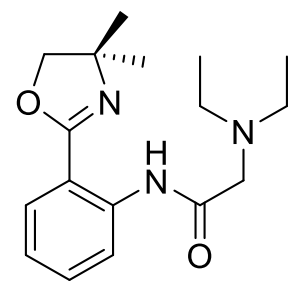

\section{Molecular weight: $303.41 \mathrm{~g} \mathrm{~mol}^{-1}$}

Compound $2(1.27 \mathrm{~g}, 4.78 \mathrm{mmol})$ was added to the stirring solution of potassium carbonate $(1.32 \mathrm{~g}, 9.55 \mathrm{mmol})$ and diethylamine $(1.00 \mathrm{~mL}, 9.55 \mathrm{mmol})$ in $\mathrm{MeCN}(30.0$ $\mathrm{mL})$. An orange-coloured solution was then heated to reflux temperature $\left(\sim 80^{\circ} \mathrm{C}\right)$. The reaction progress was monitored by TLC, and the reflux was stopped after $24 \mathrm{~h}$. The reaction mixture appeared dark brown with light brown precipitate. After it cooled down 
to RT, it was gravity filtered and the solution was left to evaporate. After evaporation the compound appeared brown in colour and waxy in composition. The compound was purified by DCFC and the product was collected as yellow oil from fractions 8 to $18(1.1$ g, $69 \%$ yield, pure): $\mathrm{R}_{f}=0.59$ (hexanes-EtOAc, 4:1).

IR (NaCl): 2971, 1686, 1641, 1581, 1520, 1446, 1283, 1056, 1046, 773, $754 \mathrm{~cm}^{-1}$.

${ }^{1} \mathrm{H}$ NMR $\left(400 \mathrm{MHz}, \mathrm{CDCl}_{3}\right): \delta=12.64(\mathrm{~s}, 1 \mathrm{H}), 8.88(\mathrm{dd}, J=8.8 \mathrm{~Hz}, J=1.2 \mathrm{~Hz}, 1 \mathrm{H})$, 7.85 (ddd, $J=8.0 \mathrm{~Hz}, J=1.6 \mathrm{~Hz}, J=0.4 \mathrm{~Hz}, 1 \mathrm{H}$ ), 7.44 (dddd, $J=8.8 \mathrm{~Hz}, J=7.2 \mathrm{~Hz}, J$ $=1.6 \mathrm{~Hz}, J=0.4 \mathrm{~Hz}, 1 \mathrm{H}), 7.06(\mathrm{ddd}, J=7.6 \mathrm{~Hz}, J=7.2 \mathrm{~Hz}, J=1.2 \mathrm{~Hz}, 1 \mathrm{H}), 4.04(\mathrm{~s}, 2$ H), $3.24(\mathrm{~s}, 2 \mathrm{H}), 2.67(\mathrm{q}, J=7.2 \mathrm{~Hz}, 4 \mathrm{H}), 1.39(\mathrm{~s}, 6 \mathrm{H}), 1.09(\mathrm{t}, J=7.2 \mathrm{~Hz}, 6 \mathrm{H})$.

${ }^{13} \mathrm{C}$ NMR $\left(100 \mathrm{MHz}, \mathrm{CDCl}_{3}\right): \delta=172.8,161.1,139.6,132.2,129.3,122.4,120.1,114.3$ $77.8,68.4,58.2,49.3,28.7,12.1$.

Anal. Calcd for $\mathrm{C}_{17} \mathrm{H}_{25} \mathrm{~N}_{3} \mathrm{O}_{2}$ : C, 67.30; $\mathrm{H}, 8.31 ; \mathrm{N}, 13.85 \%$. Found: $\mathrm{C}, 67.52 ; \mathrm{H}, 8.20 ; \mathrm{N}$, $13.75 \%$.

N-(2-(4,4-Dimethyl-4,5-dihydrooxazol-2-yl)phenyl)-2-(methyl(2-(pyridin-2yl)ethyl) amino)acetamide (3c)

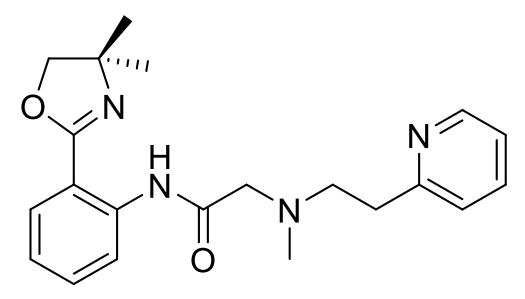

Molecular weight: $366.46 \mathrm{~g} \mathrm{~mol}^{-1}$

The compound was prepared similarly as for $\mathbf{3 b}$ from 2-(2-methylaminoethyl)pyridine $(0.50 \mathrm{~mL}, 3.60 \mathrm{mmol}), 2(0.48 \mathrm{~g}, 1.80 \mathrm{mmol})$ and potassium carbonate $(0.50 \mathrm{~g}, 3.60$ $\mathrm{mmol}$ ) in MeCN (10 mL) for $23 \mathrm{~h}$. The compound was purified by DCFC and the product 
was collected as yellowish powder from fractions 20 to $34\left(0.30 \mathrm{~g}, 45 \%\right.$ yield, pure): $R_{f}=$ 0.12 (hexanes-EtOAc, 3:2).

${ }^{1} \mathrm{H} \mathrm{NMR}\left(400 \mathrm{MHz}, \mathrm{CDCl}_{3}\right): \delta=12.65(\mathrm{~s}, 1 \mathrm{H}), 8.84(\mathrm{dd}, J=8.4 \mathrm{~Hz}, J=1.2 \mathrm{~Hz}, 1 \mathrm{H})$, $8.50(\mathrm{ddd}, J=4.8 \mathrm{~Hz}, J=2.0 \mathrm{~Hz}, J=0.8 \mathrm{~Hz}, 1 \mathrm{H}), 7.84(\mathrm{dd}, J=8.0 \mathrm{~Hz}, J=1.6 \mathrm{~Hz}, 1$ H), $7.54(\mathrm{td}, J=7.6 \mathrm{~Hz}, J=2.0 \mathrm{~Hz}, 1 \mathrm{H}$ ), 7.44 (ddd, $J=8.8 \mathrm{~Hz}, J=7.6 \mathrm{~Hz}, J=1.6 \mathrm{~Hz}, 1$ H), $7.14(\mathrm{dt}, J=8.0 \mathrm{~Hz}, J=0.8 \mathrm{~Hz}, 1 \mathrm{H}), 7.04-7.11(\mathrm{~m}, 2 \mathrm{H}), 4.02(\mathrm{~s}, 2 \mathrm{H}), 3.31(\mathrm{~s}, 2 \mathrm{H})$, 2.95-3.10 (m, $4 \mathrm{H}), 2.50(\mathrm{~s}, 3 \mathrm{H}), 1.38(\mathrm{~s}, 6 \mathrm{H})$.

${ }^{13} \mathrm{C}$ NMR $\left(100 \mathrm{MHz}, \mathrm{CDCl}_{3}\right): \delta=171.2,161.2,160.0,149.4,139.6,136.5,132.3,129.2$ $123.3,122.5,121.4,120.1,114.3,77.8,68.3,62.2,58.1,43.6,35.9,28.8$.

Anal. Calcd for $\mathrm{C}_{21} \mathrm{H}_{26} \mathrm{~N}_{4} \mathrm{O}_{2}$ : C, 68.83; $\mathrm{H}, 7.15 ; \mathrm{N}, 15.29 \%$. Found: $\mathrm{C}, 68.56 ; \mathrm{H}, 7.14 ; \mathrm{N}$, $15.23 \%$.

2-((3S,5S,7S)-Adamantan-1-yl(methyl)amino)-N-(2-(4,4-dimethyl-4,5-dihydrooxazol $-2-\mathrm{yl})$ phenyl) acetamide (3d)

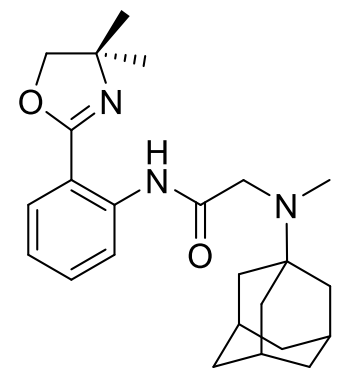

Molecular weight: $395.55 \mathrm{~g} \mathrm{~mol}^{-1}$

The compound was prepared similarly as for $3 \mathrm{~b}$ from $\mathrm{N}$-methyladamantylamine $(0.17 \mathrm{~g}$, $1.00 \mathrm{mmol}), 2(0.24 \mathrm{~g}, 0.90 \mathrm{mmol})$ and potassium carbonate $(0.14 \mathrm{~g}, 1.00 \mathrm{mmol})$ in MeCN (20 mL) for 28 hours. The compound was recrystallized from DCM and hexanes as yellow wax $\left(0.20 \mathrm{~g}, 56 \%\right.$ yield, pure): $\mathrm{R}_{f}=0.66$ (hexanes-EtOAc, $\left.4: 1\right)$. 
${ }^{1} \mathrm{H}$ NMR $\left(400 \mathrm{MHz}, \mathrm{CDCl}_{3}\right): \delta=12.24(\mathrm{~s} \mathrm{br}, 1 \mathrm{H}), 8.86(\mathrm{dd}, J=8.4 \mathrm{~Hz}, J=0.8 \mathrm{~Hz}, 1 \mathrm{H})$, $7.88(\mathrm{dd}, J=7.6 \mathrm{~Hz}, J=1.2 \mathrm{~Hz}, 1 \mathrm{H}), 7.44(\mathrm{ddd}, J=8.8 \mathrm{~Hz}, J=7.6 \mathrm{~Hz}, J=1.6 \mathrm{~Hz}, 1$ H), 7.06 (ddd, $J=8.0 \mathrm{~Hz}, J=7.6 \mathrm{~Hz}, J=0.8 \mathrm{~Hz}, 1 \mathrm{H}$ ), 4.02, (s, $2 \mathrm{H}), 3.31$ (s, $2 \mathrm{H}), 2.07-$ $2.13(\mathrm{~m} \mathrm{br}, 3 \mathrm{H}), 1.76(\mathrm{~d}, J=2.4 \mathrm{~Hz}, 6 \mathrm{H}), 1.63(\mathrm{q}, J=12.4 \mathrm{~Hz}, 6 \mathrm{H}), 1.42(\mathrm{~s}, 6 \mathrm{H})$.

${ }^{13} \mathrm{C}$ NMR $\left(100 \mathrm{MHz}, \mathrm{CDCl}_{3}\right): \delta=173.6,161.2,139.6,132.2,129.6,122.5,120.5,114.6$, $77.8,68.6,56.0,54.4,38.7,36.8,36.2,29.6,28.7$.

Anal. Calcd for $\mathrm{C}_{24} \mathrm{H}_{33} \mathrm{~N}_{3} \mathrm{O}_{2} \cdot 1 / 2 \mathrm{H}_{2} \mathrm{O}: \mathrm{C}, 71.25 ; \mathrm{H}, 8.47 ; \mathrm{N}, 10.39 \%$. Found: $\mathrm{C}, 71.01 ; \mathrm{H}$, $8.49 ; \mathrm{N}, 10.39 \%$.

$N$-(2-(4,4-Dimethyl-4,5-dihydrooxazol-2-yl)phenyl)-2-(pyrrolidin-1-yl)acetamide (3e)

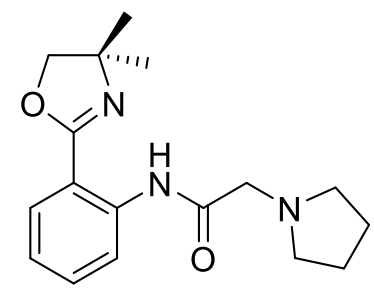

Molecular weight: $301.39 \mathrm{~g} \mathrm{~mol}^{-1}$

The compound was prepared similarly as for $\mathbf{3 b}$ from pyrrolidine $(0.58 \mathrm{~mL}, 6.95 \mathrm{mmol})$, $2(1.20 \mathrm{~g}, 4.50 \mathrm{mmol})$ and potassium carbonate $(1.24 \mathrm{~g}, 9.00 \mathrm{mmol})$ in $\mathrm{MeCN}(30 \mathrm{~mL})$ for $7 \mathrm{~h}$. The compound was recrystallized from DCM and hexane as beige solid $(0.62 \mathrm{~g}$, 73\% yield, pure): $\mathrm{Mp} 106-108{ }^{\circ} \mathrm{C} ; \mathrm{R}_{f}=0.28$ (hexanes-EtOAc, $4: 1$ ).

${ }^{1} \mathrm{H} \operatorname{NMR}\left(400 \mathrm{MHz}, \mathrm{CDCl}_{3}\right): \delta=12.47(\mathrm{~s}, 1 \mathrm{H}), 8.83(\mathrm{dd}, J=8.4 \mathrm{~Hz}, J=0.8 \mathrm{~Hz}, 1 \mathrm{H})$, 7.84 (ddd, $J=8.0 \mathrm{~Hz}, J=2.0 \mathrm{~Hz}, J=0.4 \mathrm{~Hz}, 1 \mathrm{H}$ ), 7.44 (dddd, $J=9.2 \mathrm{~Hz}, J=7.2 \mathrm{~Hz}, J$ $=1.6 \mathrm{~Hz}, J=0.4 \mathrm{~Hz}, 1 \mathrm{H}), 7.07(\mathrm{ddd}, J=8.0 \mathrm{~Hz}, J=7.6 \mathrm{~Hz}, J=1.2 \mathrm{~Hz}, 1 \mathrm{H}), 4.04(\mathrm{~s}, 2$ H), 3.37 (s, 2 H), 2.68-2.76 (m, 4 H), 1.82-1.91 (m, 4 H), 1.39 (s, $6 \mathrm{H})$. 
${ }^{13} \mathrm{C}$ NMR $\left(100 \mathrm{MHz}, \mathrm{CDCl}_{3}\right): \delta=171.3,161.3,139.6,132.3,129.2,122.5,120.3,114.3$, $77.8,68.3,61.6,54.7,28.6,24.5$.

Anal. Calcd for $\mathrm{C}_{17} \mathrm{H}_{23} \mathrm{~N}_{3} \mathrm{O}_{2}$ : C, 67.75; $\mathrm{H}, 7.69 ; \mathrm{N}, 13.94 \%$. Found: $\mathrm{C}, 67.93 ; \mathrm{H}, 7.66 ; \mathrm{N}$, $13.96 \%$.

\section{2-(Bis(pyridin-2-ylmethyl)amino)-N-(2-(4,4-dimethyl-4,5-dihydrooxazol-2-yl)phenyl)} acetamide (3f)

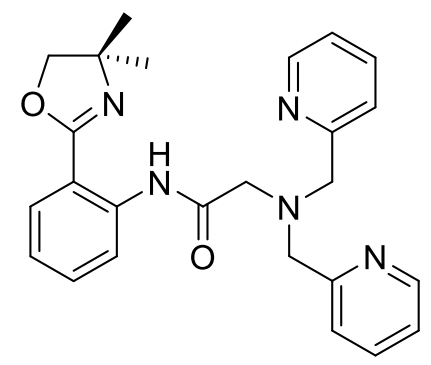

\section{Molecular weight: $429.52 \mathrm{~g} \mathrm{~mol}^{-1}$}

The compound was prepared similarly as for $\mathbf{3 b}$ from $2,2^{\prime}$-dipicolylamine $(0.20 \mathrm{~mL}, 1.12$ $\mathrm{mmol}), 2(0.30 \mathrm{~g}, 1.12 \mathrm{mmol})$ and potassium carbonate $(0.31 \mathrm{~g}, 2.25 \mathrm{mmol})$ in $\mathrm{MeCN}$ $(20 \mathrm{~mL})$ for $24 \mathrm{~h}$. The compound was purified by DCFC from fractions 29 to 38 , then washed with $\mathrm{Et}_{2} \mathrm{O}$ and collected as white solid $\left(0.14 \mathrm{~g}, 30 \%\right.$ yield, pure): $\mathrm{R}_{f}=0.05$ (hexanes-ETOAc, 1:1).

${ }^{1} \mathrm{H}$ NMR $\left(400 \mathrm{MHz}, \mathrm{CDCl}_{3}\right): \delta=12.57(\mathrm{~s}, 1 \mathrm{H}), 8.76(\mathrm{dd}, J=8.4 \mathrm{~Hz}, J=0.8 \mathrm{~Hz}, 1 \mathrm{H})$, 8.55 (dt, $J=6.0 \mathrm{~Hz}, J=1.2 \mathrm{~Hz}, 2 \mathrm{H}$ ), 7.88 (dd, $J=8.0 \mathrm{~Hz}, J=2.0 \mathrm{~Hz}, 1 \mathrm{H}$ ), 7.45 (ddd, $J$ $=8.8 \mathrm{~Hz}, J=7.6 \mathrm{~Hz}, J=2.0 \mathrm{~Hz}, 7.61-7.72(\mathrm{~m}, 4 \mathrm{H}), 7.18(\mathrm{ddd}, J=6.8 \mathrm{~Hz}, J=5.2 \mathrm{~Hz}, J$ $=2.4 \mathrm{~Hz}, 2 \mathrm{H}$ ), 7.10 (ddd, J = 8.0 Hz, J= $7.6 \mathrm{~Hz}, J=1.2 \mathrm{~Hz}, 1 \mathrm{H}), 4.12(\mathrm{~s}, 4 \mathrm{H}), 4.08(\mathrm{~s}$, $2 \mathrm{H}), 3.49$ (s, $2 \mathrm{H}), 1.40$ (s, $6 \mathrm{H})$. 
${ }^{13} \mathrm{C} \mathrm{NMR}\left(100 \mathrm{MHz}, \mathrm{CDCl}_{3}\right): \delta=170.6,161.6,157.9,149.2,139.4,136.4,132.3,129.2$ 123.6, 122.5, 122.2, 120.2, 114.1, 77.7, 68.3, 60.6, 57.9, 28.7 .

Anal. Calcd for $\mathrm{C}_{25} \mathrm{H}_{27} \mathrm{~N}_{5} \mathrm{O}_{2}$ : C, 69.91; $\mathrm{H}, 6.34 ; \mathrm{N}, 16.31 \%$. Found: $\mathrm{C}, 69.88 ; \mathrm{H}, 6.26 ; \mathrm{N}$, $16.13 \%$.

$N$-(2-(4,4-Dimethyl-4,5-dihydrooxazol-2-yl)phenyl)-2-(1,4,7,10-tetraoxa-13-azacyclo pentadecan-13-yl) acetamide (3g)

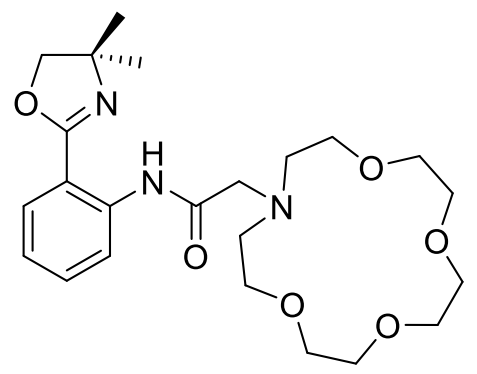

\section{Molecular weight: $449.55 \mathrm{~g} \mathrm{~mol}^{-1}$}

The compound was prepared similarly as for $3 \mathrm{~b}$ from 1-aza-15-crown-5 (0.22 g, 1.00 $\mathrm{mmol}), 2(0.27 \mathrm{~g}, 1.00 \mathrm{mmol})$ and potassium carbonate $(0.28 \mathrm{~g}, 2.00 \mathrm{mmol})$ in $\mathrm{MeCN}$ $(25 \mathrm{~mL})$ for $17 \mathrm{~h}$. The compound was dissolved in $\mathrm{CHCl}_{3}(30 \mathrm{~mL})$ and extracted with $\mathrm{H}_{2} \mathrm{O}(30 \mathrm{~mL})$, and then brine $(10 \mathrm{~mL})$. Organic layer was dried over $\mathrm{MgSO}_{4}$. Collected as yellow wax (0.30 g, $67 \%$ yield, pure): $\mathrm{R}_{f}=0.15$ (hexanes-EtOAc, $\left.1: 1\right)$.

IR (KBr): 3089, 2867, 1683, 1636, 1582, 1520, 1446, 1355, 1284, 1127, 1057, 968, 934 $755 \mathrm{~cm}^{-1}$.

${ }^{1} \mathrm{H}$ NMR $\left(400 \mathrm{MHz}, \mathrm{CDCl}_{3}\right): \delta=12.52(\mathrm{~s} \mathrm{br}, 1 \mathrm{H}), 8.82(\mathrm{~d}, J=8.4 \mathrm{~Hz}), 7.84(\mathrm{~d}, J=8.0$ $\mathrm{Hz}, 1 \mathrm{H}), 7.43(\mathrm{t}, J=8.4 \mathrm{~Hz}, 1 \mathrm{H}), 7.06(\mathrm{t}, J=7.6 \mathrm{~Hz}, 1 \mathrm{H}), 4.03(\mathrm{~s}, 2 \mathrm{H}), 3.72(\mathrm{t}, J=6.0$ $\mathrm{Hz}, 4 \mathrm{H}), 3.60-3.68(\mathrm{~m}, 12 \mathrm{H}), 3.48(\mathrm{~s}, 2 \mathrm{H}), 3.04(\mathrm{t}, \mathrm{J}=6.0 \mathrm{~Hz}, 4 \mathrm{H}), 1.40(\mathrm{~s}, 6 \mathrm{H})$.

${ }^{13} \mathrm{C}$ NMR $\left(100 \mathrm{MHz}, \mathrm{CDCl}_{3}\right): \delta=171.8,161.2,139.5,132.2,129.2,122.4,120.0,114.1$ $77.6,70.9,70.5,70.4,69.4,68.2,60.0,54.5,28.7$. 
Anal. Calcd for $\mathrm{C}_{23} \mathrm{H}_{35} \mathrm{~N}_{3} \mathrm{O}_{6}$ : C, 61.45; $\mathrm{H}, 7.85 ; \mathrm{N}, 9.35 \%$. Found: $\mathrm{C}, 61.38 ; \mathrm{H}, 7.82 ; \mathrm{N}$, $9.52 \%$.

2-(Allyl(methyl)amino)-N-(2-(4,4-dimethyl-4,5-dihydrooxazol-2-yl)phenyl)acetamide (3h)

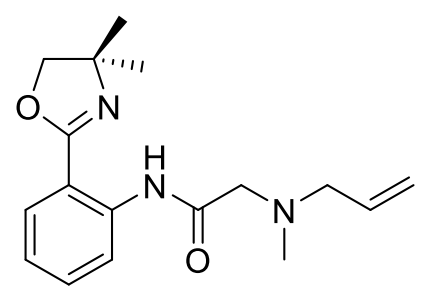

Molecular weight: $301.39 \mathrm{~g} \mathrm{~mol}^{-1}$

The compound was prepared similarly as for $\mathbf{3 b}$ from allylmethylamine $(0.30 \mathrm{~mL}, 3.10$ $\mathrm{mmol}), 2(0.80 \mathrm{~g}, 3.00 \mathrm{mmol})$ and potassium carbonate $(0.71 \mathrm{~g}, 5.10 \mathrm{mmol})$ in $\mathrm{MeCN}$ (30 mL) for $48 \mathrm{~h}$. The compound was purified by DCFC and the product was collected as yellowish oil from fractions 7 to $10\left(0.37 \mathrm{~g}, 41 \%\right.$ yield, pure): $\mathrm{R}_{f}=0.53$ (hexanesEtOAc, 4:1).

IR (KBr): 3083, 2971, 1683, 1643, 1582, 1520, 1447, 1354, 1293, 1209, 1056, 1046 $968,926,773,754,690 \mathrm{~cm}^{-1}$.

${ }^{1} \mathrm{H}$ NMR $\left(400 \mathrm{MHz}, \mathrm{CDCl}_{3}\right): \delta=12.71(\mathrm{~s}, 1 \mathrm{H}), 8.86(\mathrm{dd}, J=8.4 \mathrm{~Hz}, J=0.8 \mathrm{~Hz}, 1 \mathrm{H})$, $7.84(\mathrm{ddd}, J=8.0 \mathrm{~Hz}, J=1.6 \mathrm{~Hz}, J=0.4 \mathrm{~Hz}, 1 \mathrm{H}$ ), 7.43 (dddd, $J=9.2 \mathrm{~Hz}, J=7.6 \mathrm{~Hz}, J$ $=2.0 \mathrm{~Hz}, J=0.4 \mathrm{~Hz}, 1 \mathrm{H}$ ), 7.06 (ddd, $J=7.6 \mathrm{~Hz}, J=7.2 \mathrm{~Hz}, J=1.2 \mathrm{~Hz}, 1 \mathrm{H}$ ), 5.95 (ddt, $J=16.8 \mathrm{~Hz}, J=10.4 \mathrm{~Hz}, J=6.8 \mathrm{~Hz}, 1 \mathrm{H}), 5.23(\mathrm{dq}, J=17.2 \mathrm{~Hz}, J=1.6 \mathrm{~Hz}, 1 \mathrm{H}), 5.16$ (ddt, $J=10.0 \mathrm{~Hz}, J=2.0 \mathrm{~Hz}, J=0.8 \mathrm{~Hz}, 1 \mathrm{H}$ ), $4.03(\mathrm{~s}, 2 \mathrm{H}$ ), $3.20(\mathrm{~s}, 2 \mathrm{H}), 3.16$ (dt, $J=$ $6.8 \mathrm{~Hz}, J=1.6 \mathrm{~Hz}, 2 \mathrm{H}), 2.38(\mathrm{~s}, 3 \mathrm{H}), 1.39(\mathrm{~s}, 6 \mathrm{H})$. 
${ }^{13} \mathrm{C} \mathrm{NMR}\left(100 \mathrm{MHz}, \mathrm{CDCl}_{3}\right): \delta=171.4,161.2,139.6,135.2,132.2,129.2,122.4,120.0$, $118.4,114.2,77.7,68.2,61.4,61.1,43.7,28.6$.

Anal. Calcd for $\mathrm{C}_{17} \mathrm{H}_{23} \mathrm{~N}_{3} \mathrm{O}_{2}$ : C, 67.75; $\mathrm{H}, 7.69 ; \mathrm{N}, 13.94 \%$. Found: $\mathrm{C}, 67.96 ; \mathrm{H}, 7.67 ; \mathrm{N}$, $13.73 \%$.

$N$-(2-(4,4-Dimethyl-4,5-dihydrooxazol-2-yl)phenyl)-2-(isopropyl(methyl)amino)ace tamide (3i)

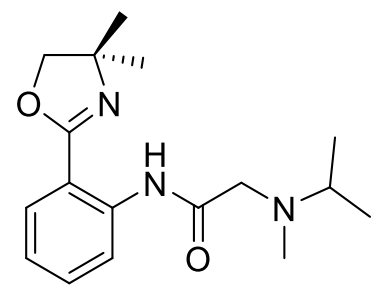

Molecular weight: $303.41 \mathrm{~g} \mathrm{~mol}^{-1}$

The compound was prepared similarly as for $\mathbf{3 b}$ from $\mathrm{N}$-isopropylmethylamine $(1.04 \mathrm{~g}$, $10.0 \mathrm{mmol}), 2(2.67 \mathrm{~g}, 10.0 \mathrm{mmol})$ and potassium carbonate $(2.76 \mathrm{~g}, 20.0 \mathrm{mmol})$ in MeCN $(50 \mathrm{~mL})$ for $24 \mathrm{~h}$. The compound was dissolved in DCM $(30 \mathrm{~mL})$ and extracted with $\mathrm{H}_{2} \mathrm{O}(2 \times 30 \mathrm{~mL})$, and then brine $(30 \mathrm{~mL})$. Organic layer was dried over $\mathrm{MgSO}_{4}$. The product was collected as orange oil $\left(2.00 \mathrm{~g}, 66 \%\right.$ yield, pure): $R_{f}=0.14$ (hexanesETOAc, 4:1).

${ }^{1} \mathrm{H}$ NMR $\left(400 \mathrm{MHz}, \mathrm{CDCl}_{3}\right): \delta=12.63(\mathrm{~s} \mathrm{br}, 1 \mathrm{H}), 8.88(\mathrm{~d}, J=8.4 \mathrm{~Hz}, 1 \mathrm{H}), 7.84(\mathrm{~d}, J=$ $7.6 \mathrm{~Hz}, 1 \mathrm{H}), 7.43(\mathrm{t}, J=8.4 \mathrm{~Hz}, 1 \mathrm{H}), 7.05(\mathrm{t}, J=7.6 \mathrm{~Hz}, 1 \mathrm{H}), 4.02(\mathrm{~s}, 2 \mathrm{H}), 3.17(\mathrm{~s}, 2$ H), 2.93 (sept, $J=6.8 \mathrm{~Hz}, 1 \mathrm{H}), 2.35(\mathrm{~s}, 3 \mathrm{H}), 1.38(\mathrm{~s}, 6 \mathrm{H}), 1.07(\mathrm{~d}, J=6.8 \mathrm{~Hz}, 6 \mathrm{H})$.

${ }^{13} \mathrm{C}$ NMR $\left(100 \mathrm{MHz}, \mathrm{CDCl}_{3}\right): \delta=172.5,161.0,139.5,132.1,129.2,122.3,120.0,114.3$ $77.6,68.2,57.1,54.3,40.2,28.5,18.2$. 
Anal. Calcd for $\mathrm{C}_{17} \mathrm{H}_{25} \mathrm{~N}_{3} \mathrm{O}_{2}$ : C, 67.30; H, 8.31; N, 13.85\%. Found: C, 67.18; H, 8.28; N, $13.96 \%$.

\section{2-(Diallylamino)-N-(2-(4,4-dimethyl-4,5-dihydroox azol-2-yl)phenyl)acetamide (3j)}

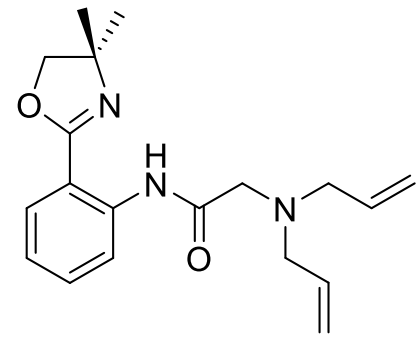

Molecular weight: $327.43 \mathrm{~g} \mathrm{~mol}^{-1}$

The compound was prepared similarly as for $3 \mathbf{b}$ from diallylamine $(0.43 \mathrm{~mL}, 3.50 \mathrm{mmol})$, $2(0.80 \mathrm{~g}, 3.00 \mathrm{mmol})$ and potassium carbonate $(0.83 \mathrm{~g}, 6.00 \mathrm{mmol})$ in $\mathrm{MeCN}(25 \mathrm{~mL})$. The compound was recrystallized from petroleum ether as orange wax $(0.72 \mathrm{~g}, 74 \%$ yield, pure): $\mathrm{R}_{f}=0.67$ (hexanes-EtOAc, 4:1).

${ }^{1} \mathrm{H}$ NMR $\left(400 \mathrm{MHz}, \mathrm{CDCl}_{3}\right): \delta=12.61(\mathrm{~s}, 1 \mathrm{H}), 8.86(\mathrm{~d}, J=8.8 \mathrm{~Hz}, 1 \mathrm{H}), 7.86(\mathrm{dd}, J=$ $1.6 \mathrm{~Hz}, J=8.0 \mathrm{~Hz}, 1 \mathrm{H}), 7.44(\mathrm{dt}, J=1.6 \mathrm{~Hz}, J=8.8 \mathrm{~Hz}, 1 \mathrm{H}), 7.07(\mathrm{t}, J=8.0 \mathrm{~Hz}, 1 \mathrm{H})$, 5.97 (tdd, $J=6.8 \mathrm{~Hz}, J=10.4 \mathrm{~Hz}, J=17.2 \mathrm{~Hz}, 2 \mathrm{H}), 5.21$ (d, $J=17.2 \mathrm{~Hz}, 2 \mathrm{H}), 5.15$ (d, $J=10.4 \mathrm{~Hz}, 2 \mathrm{H}), 4.05(\mathrm{~s}, 2 \mathrm{H}), 3.27(\mathrm{~s}, 2 \mathrm{H}), 3.24(\mathrm{~d}, J=6.8 \mathrm{~Hz}, 4 \mathrm{H}), 1.41(\mathrm{~s}, 6 \mathrm{H})$.

${ }^{13} \mathrm{C}$ NMR $\left(100 \mathrm{MHz}, \mathrm{CDCl}_{3}\right): \delta=171.8,161.2,139.5,134.8,132.2,129.2,122.3,119.9$ $118.6,114.1,77.6,68.3,58.5,57.6,28.6$.

Anal. Calcd for $\mathrm{C}_{19} \mathrm{H}_{25} \mathrm{~N}_{3} \mathrm{O}_{2} \cdot 1 / 4 \mathrm{H}_{2} \mathrm{O}: \mathrm{C}, 68.75 ; \mathrm{H}, 7.74 ; \mathrm{N}, 12.66 \%$. Found: $\mathrm{C}, 68.46 ; \mathrm{H}$, $7.64 ; \mathrm{N}, 12.43 \%$. 
$N$-(2-(4,4-Dimethyl-4,5-dihydrooxazol-2-yl)phenyl)-2-((2-hydroxyethyl)(methyl) amino)acetamide (3k)

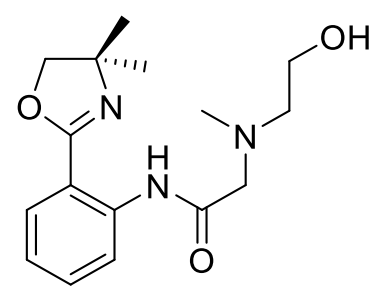

Molecular weight: $305.38 \mathrm{~g} \mathrm{~mol}^{-1}$

In a $50 \mathrm{~mL}$ three neck round bottom flask, $4(0.22,1.20 \mathrm{mmol})$ and $\mathrm{K}_{2} \mathrm{CO}_{3}(0.21 \mathrm{~g}, 1.50$ $\mathrm{mmol})$ were dissolved in $\mathrm{MeCN}(15 \mathrm{~mL})$ under an atmosphere of nitrogen gas. The solution was stirred for $15 \mathrm{~min}$. Then the solution of 2 ( $0.20 \mathrm{~g}, 0.75 \mathrm{mmol})$ in $\mathrm{MeCN}$ (10 $\mathrm{mL}$ ) was transferred to the reaction flask. The mixture was stirred at reflux temperature $\left(80^{\circ} \mathrm{C}\right)$ for $18 \mathrm{~h}$. After the reflux was complete, the solution was filtered and allowed to evaporate. The product was a light yellow wax $(0.20 \mathrm{~g}, 88 \%$ calculated yield, crude).

${ }^{1} \mathrm{H}$ NMR $\left(400 \mathrm{MHz}, \mathrm{CDCl}_{3}\right): \delta=12.22(\mathrm{~s} \mathrm{br}, 1 \mathrm{H}), 8.80(\mathrm{~d}, J=8.0 \mathrm{~Hz}, 1 \mathrm{H}), 7.80(\mathrm{dd}, J=$ $8.0 \mathrm{~Hz}, J=1.6 \mathrm{~Hz}, 1 \mathrm{H}), 7.42(\mathrm{t}, J=8.0 \mathrm{~Hz}, 1 \mathrm{H}), 7.05(\mathrm{t}, J=8.0 \mathrm{~Hz}, 1 \mathrm{H}), 4.03(\mathrm{~s}, 2 \mathrm{H})$, $3.62(\mathrm{t}, J=4.8 \mathrm{~Hz}, 2 \mathrm{H}), 3.24(\mathrm{~s}, 2 \mathrm{H}), 2.66(\mathrm{t}, J=4.8 \mathrm{~Hz}, 2 \mathrm{H}), 2.43(\mathrm{~s}, 3 \mathrm{H}), 1.40(\mathrm{~s}, 6$ H).

${ }^{13} \mathrm{C} \mathrm{NMR}\left(100 \mathrm{MHz}, \mathrm{CDCl}_{3}\right): \delta=170.7,162.2,139.1,132.6,129.6,122.8,120.0,114.3$, $77.9,68.6,62.8,60.8,59.2,44.2,28.5$.

Anal. Calcd for $\mathrm{C}_{16} \mathrm{H}_{23} \mathrm{~N}_{3} \mathrm{O}_{3}: \mathrm{C}, 62.93 ; \mathrm{H}, 7.59 ; \mathrm{N}, 13.76 \%$. Found: $\mathrm{C}, 62.56 ; \mathrm{H}, 7.23 ; \mathrm{N}$, $12.06 \%$. 


\section{Synthesis of 1-benzylimidazole ${ }^{62}$}<smiles>c1ccc(Cn2ccnc2)cc1</smiles>

Molecular weight: $158.20 \mathrm{~g} \mathrm{~mol}^{-1}$

Potassium carbonate $(3.99 \mathrm{~g}, 28.8 \mathrm{mmol})$ and imidazole hydrochloride $(1.00 \mathrm{~g}, 9.60$ $\mathrm{mmol}$ ) were dissolved in $\mathrm{MeCN}(30 \mathrm{~mL})$. Benzyl bromide $(1.25 \mathrm{~mL}, 10.6 \mathrm{mmol})$ was added dropwise to the stirring solution at RT. After 70 hours, the solution was concentrated and redissolved in DCM and extracted with $\mathrm{H}_{2} \mathrm{O}(3 \times 30 \mathrm{~mL})$. Organic layer was dried over $\mathrm{MgSO}_{4}$. The product was collected as off-white wax $(0.63 \mathrm{~g}, 42 \%$ yield, pure).

${ }^{1} \mathrm{H}$ NMR matches reported literature values. ${ }^{62}$

$N$-(2-(4,4-dimethyl-4,5-dihydrooxazol-2-yl)phenyl)-2-(1H-imidazol-1-yl)acetamide (2I)<smiles>C[C@H]1COC(c2ccccc2NC(=O)Cn2ccnc2)=N1</smiles>

Molecular weight: $298.35 \mathrm{~g} \mathrm{~mol}^{-1}$

Imidazole (0.05 g, $0.750 \mathrm{mmol}), 2(0.22 \mathrm{~g}, 0.82 \mathrm{mmol})$ and $\mathrm{K}_{2} \mathrm{CO}_{3}(0.31 \mathrm{~g}, 2.25 \mathrm{mmol})$ were dissolved in $\mathrm{MeCN}(15.0 \mathrm{~mL})$. The bright yellow reaction mixture was refluxed for $24 \mathrm{~h}$. It was then cooled to RT, the reaction mixture was gravity filtered, and the filtrate was concentrated and then washed with $\mathrm{Et}_{2} \mathrm{O}(3 \times 5.0 \mathrm{~mL})$. The compound was recrystallized from DCM and hexanes as white solid ( $0.12 \mathrm{~g}, 56 \%$ yield; pure): $R_{f}=0.18$ (hexanes-EtOAc, 4:1). 
${ }^{1} \mathrm{H}$ NMR $\left(400 \mathrm{MHz}, \mathrm{CDCl}_{3}\right): \delta=12.40(\mathrm{~s}, 1 \mathrm{H}), 8.71(\mathrm{~d}, J=8.4 \mathrm{~Hz}, 1 \mathrm{H}), 7.84(\mathrm{~d}, J=7.6$ $\mathrm{Hz}, 1 \mathrm{H}), 7.62(\mathrm{~s}, 1 \mathrm{H}), 7.46(\mathrm{t}, J=7.6 \mathrm{~Hz}, 1 \mathrm{H}), 7.16(\mathrm{~s}, 1 \mathrm{H}), 7.12(\mathrm{t}, J=7.6 \mathrm{~Hz}, 1 \mathrm{H})$, 7.04 (s, $1 \mathrm{H}), 4.80$ (s, $2 \mathrm{H}), 3.98(\mathrm{~s}, 2 \mathrm{H}), 1.30(\mathrm{~s}, 6 \mathrm{H})$.

${ }^{13} \mathrm{C}$ NMR $\left(100 \mathrm{MHz}, \mathrm{CDCl}_{3}\right): \delta=165.7,161.7,138.8,138.3,132.5,130.4,129.2,123.3$, $120.1,120.0,113.9,77.9,68.2,51.4,28.2$.

Anal. Calcd for $\mathrm{C}_{16} \mathrm{H}_{18} \mathrm{~N}_{4} \mathrm{O}_{2}: \mathrm{C}, 64.41 ; \mathrm{H}, 6.08 ; \mathrm{N}, 18.78 \%$. Found: $\mathrm{C}, 64,53 ; \mathrm{H}, 6.17 ; \mathrm{N}$, $16.32 \%$.

1-Benzyl-3-(2-((2-(4,4-dimethyl-4,5-dihydrooxazol-2-yl)phenyl)amino)-2-oxoethyl)$1 \mathrm{H}$-imidazol-3-ium chloride (3I)

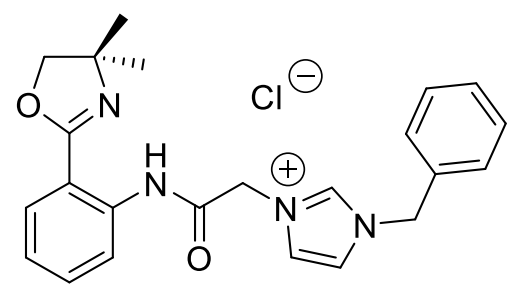

\section{Molecular weight: $424.93 \mathrm{~g} \mathrm{~mol}^{-1}$}

A solution of $2(0.40 \mathrm{~g}, 1.50 \mathrm{mmol})$ and 1-benzylimidazole $(0.19 \mathrm{~g}, 1.20 \mathrm{mmol})$ in THF/MeCN (15/3 mL) was refluxed for $24 \mathrm{~h}$. The solution was concentrated and then washed with $\mathrm{Et}_{2} \mathrm{O}$ (10 $\mathrm{mL}$ total). The compound was collected as yellow wax $(0.29 \mathrm{~g}$, $57 \%$ yield, pure): $R_{f}=0.61$ (hexanes-EtOAc, $4: 1$ ).

${ }^{1} \mathrm{H}$ NMR $\left(400 \mathrm{MHz}, \mathrm{CDCl}_{3}\right): \delta=12.96(\mathrm{~s} \mathrm{br}, 1 \mathrm{H}), 10.71(\mathrm{~s} \mathrm{br}, 1 \mathrm{H}), 8.44(\mathrm{~d}, J=8.4 \mathrm{~Hz}, 1$ H), $7.84(\mathrm{~d}, J=7.6 \mathrm{~Hz}, 1 \mathrm{H}), 7.47(\mathrm{~s} \mathrm{br}, 1 \mathrm{H}), 7.33-7.45(\mathrm{~m}, 6 \mathrm{H}), 7.21(\mathrm{~s} \mathrm{br}, 1 \mathrm{H}), 7.12(\mathrm{t}$, $J=7.6 \mathrm{~Hz}, 1 \mathrm{H}), 5.54(\mathrm{~s}, 2 \mathrm{H}), 5.50(\mathrm{~s}, 2 \mathrm{H}), 4.08(\mathrm{~s}, 2 \mathrm{H}), 1.43(\mathrm{~s}, 6 \mathrm{H})$.

${ }^{13} \mathrm{C}$ NMR $\left(100 \mathrm{MHz}, \mathrm{CDCl}_{3}\right): \delta=162.6,162.0,139.1,138.5,132.6,132.5,129.6,129.5$, $129.2,129.0,123.6,123.5,120.8,119.9,114.0,78.1,68.2,53.7,52.3,28.6$. 
Anal. Calcd for $\mathrm{C}_{23} \mathrm{H}_{25} \mathrm{CIN}_{4} \mathrm{O}_{2} \cdot 1 / 2 \mathrm{H}_{2} \mathrm{O}$ : C, 59.93; $\mathrm{H}, 6.34 ; \mathrm{N}, 12.15 \%$. Found: $\mathrm{C}, 59.86 ; \mathrm{H}$, $6.27 ; \mathrm{N}, 11.03 \%$.

$N$-(2-(4,4-Dimethyl-4,5-dihydrooxazol-2-yl)phenyl-2-(diphenylphosphoryl)acetami de $(3 \mathrm{~m} \cdot$ oxide)

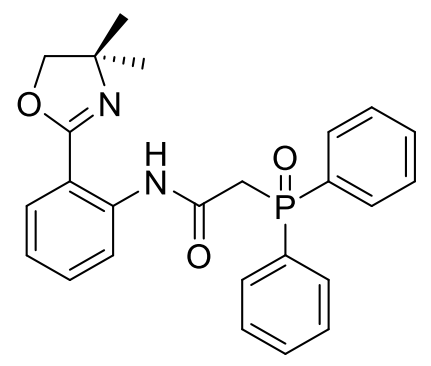

Molecular weight: $432.46 \mathrm{~g} \mathrm{~mol}^{-1}$

Compound $2(0.80 \mathrm{~g}, 3.00 \mathrm{mmol})$ was dissolved in dry THF $(15.0 \mathrm{~mL})$ and was placed into an ice bath at $-84{ }^{\circ} \mathrm{C}$ (the mixture of EtOAc/liquid $\mathrm{N}_{2}$ ). A $0.5 \mathrm{M}$ solution of $\mathrm{KPPh}_{2}$ in THF $(6.00 \mathrm{~mL}, 3.00 \mathrm{mmol})$ was added dropwise to the stirring solution. After the solution was stirred for $24 \mathrm{~h}$ under $\mathrm{N}_{2}$ at RT it was cannula transferred and the precipitate was discarded. The compound was recrystallized in air from $D C M / E t_{2} \mathrm{O}$ as yellow waxy solid (0.69 g, 55\% yield, pure): $R_{f}=0.63$ (hexanes-EtOAc, $4: 1$ ).

${ }^{1} \mathrm{H}$ NMR $\left(400 \mathrm{MHz}, \mathrm{CDCl}_{3}\right): \delta=12.43(\mathrm{~s}, 1 \mathrm{H}), 8.45(\mathrm{~d}, J=8.4 \mathrm{~Hz}, 1 \mathrm{H}), 7.82-7.90(\mathrm{~m}, 4$ H), $7.76(\mathrm{dd}, J=7.6 \mathrm{~Hz}, J=1.6 \mathrm{~Hz}, 1 \mathrm{H}), 7.40-7.53(\mathrm{~m}, 6 \mathrm{H}), 7.34$ (ddd, $J=8.8 \mathrm{~Hz}, J=$ $8.0 \mathrm{~Hz}, J=1.6 \mathrm{~Hz}, 1 \mathrm{H}), 7.03(\mathrm{td}, J=8.0 \mathrm{~Hz}, J=1.2 \mathrm{~Hz}, 1 \mathrm{H}), 4.03(\mathrm{~s}, 2 \mathrm{H}), 3.56(\mathrm{~d}, J=$ $15.6 \mathrm{~Hz}, 2 \mathrm{H}), 1.38(\mathrm{~s}, 6 \mathrm{H})$.

${ }^{13} \mathrm{C}$ NMR $\left(100 \mathrm{MHz}, \mathrm{CDCl}_{3}\right): \delta=162.7\left(\mathrm{~d}, J\left({ }^{13} \mathrm{C}-{ }^{31} \mathrm{P}\right)=5.0 \mathrm{~Hz}\right), 161.8,139.3,132.4$, 132.3, $132.2\left(\mathrm{~d}, J\left({ }^{13} \mathrm{C}-{ }^{31} \mathrm{P}\right)=3.0 \mathrm{~Hz}\right), 131.5,131.4,131.3,128.9,128.7,128.6,122.8$, $119.8,113.7,77.9,68.0,43.06\left(\mathrm{~d}, J\left({ }^{13} \mathrm{C}-{ }^{31} \mathrm{P}\right)=61.0 \mathrm{~Hz}\right), 28.7$.

${ }^{31} \mathrm{P}\left\{{ }^{1} \mathrm{H}\right\} \mathrm{NMR}\left(162 \mathrm{MHz}, \mathrm{CDCl}_{3}\right): \delta=28.49$. 
Anal. Calcd for $\mathrm{C}_{25} \mathrm{H}_{25} \mathrm{~N}_{2} \mathrm{O}_{3} \mathrm{P} \cdot 1 / 2\left(\mathrm{H}_{2} \mathrm{O}\right) \cdot \frac{1}{2} \mathrm{CH}_{2} \mathrm{Cl}_{2}$ : C, 63.29; $\mathrm{H}, 5.62 ; \mathrm{N}, 5.79 \%$. Found: $\mathrm{C}$, 64.70; H, 5.92; N, 5.75\%.

\section{Synthesis of Boc-Bn-pincer (3n)}

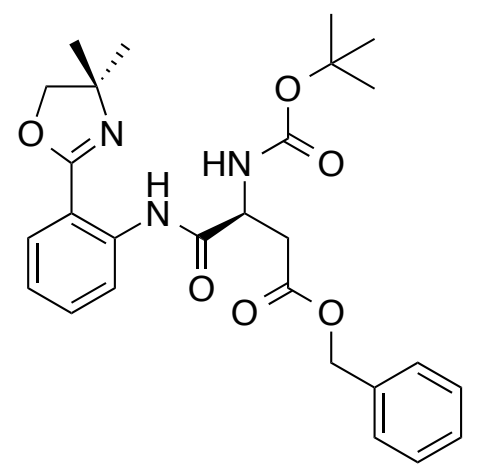

Molecular weight: $495.58 \mathrm{~g} \mathrm{~mol}^{-1}$

Boc-L-aspartic acid 4-benzyl ester $(2.00 \mathrm{~g}, 6.30 \mathrm{mmol})$ and 1 (ox- $\mathrm{NH}_{2}, 1.00 \mathrm{~g}, 5.25$ $\mathrm{mmol})$ were dissolved in DCM $(25.0 \mathrm{~mL})$ and the solution was stirred in an ice bath for 5 min. Then DCC (1.62 g, $7.88 \mathrm{mmol})$ was added to the stirring solution. After the reaction was stirred for $24 \mathrm{~h}$ at $\mathrm{RT}$, the white precipitate was filtered off (gravity filtration) and solvent was removed in vacuo. Recrystallization with DCM/hexanes (1:1) afforded compound as yellow wax $(2.60 \mathrm{~g},>99 \%$ yield; pure).

${ }^{1} \mathrm{H}$ NMR $\left(400 \mathrm{MHz}, \mathrm{CDCl}_{3}\right): \delta=12.69(\mathrm{~s}, 1 \mathrm{H}), 8.65(\mathrm{~d}, J=8.4 \mathrm{~Hz}, 1 \mathrm{H}), 7.83(\mathrm{~d}, J=7.6$ $\mathrm{Hz}, 1 \mathrm{H}$ ), 7.45 (ddd, $J=8.8 \mathrm{~Hz}, J=7.2 \mathrm{~Hz}, J=1.6 \mathrm{~Hz}, 1 \mathrm{H}), 7.35-7.31(\mathrm{~m}, 1 \mathrm{H}), 7.28-$ $7.25(\mathrm{~m}, 4 \mathrm{H}), 7.10(\mathrm{td}, J=8.0 \mathrm{~Hz}, J=1.2 \mathrm{~Hz}, 1 \mathrm{H}), 5.71(\mathrm{~d}, J=9.2 \mathrm{~Hz}, 1 \mathrm{H}), 5.20-5.03$ (m, $2 \mathrm{H}), 4.90-4.70(\mathrm{~m}, 1 \mathrm{H}), 4.06-4.00$ (m, $2 \mathrm{H}), 3.30-2.80$ (m, $2 \mathrm{H}), 1.49-1.36$ (m, 18 $H)$. 
${ }^{13} \mathrm{C} \mathrm{NMR}\left(100 \mathrm{MHz}, \mathrm{CDCl}_{3}\right): \delta=171.3,169.8,161.8,155.6,139.4,132.4,129.1,128.6$, $128.3,122.9,120.3,114.2,80.6,78.0,68.1,66.8,52.5,37.0,34.8,31.7,28.7,28.5$, $25.4,22.8,14.3$.

Anal. Calcd for $\mathrm{C}_{27} \mathrm{H}_{33} \mathrm{~N}_{3} \mathrm{O}_{6}$ : C, 65.44; $\mathrm{H}, 6.71 ; \mathrm{N}, 8.48 \%$. Found: $\mathrm{C}, 65.53 ; \mathrm{H}, 6.91 ; \mathrm{N}$, $8.23 \%$.

Synthesis of N-methyl-2-((trimethylsilyl)oxy)ethan-1-aminium chloride (4)

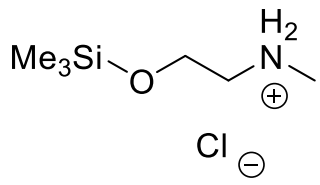

Molecular weight: $183.75 \mathrm{~g} \mathrm{~mol}^{-1}$

Dry $\mathrm{Et}_{2} \mathrm{O}(30.0 \mathrm{~mL})$ was obtained in a round bottom flask attached to a reflux condenser. 2-Methylaminoethanol $(1.07 \mathrm{~mL}, 13.3 \mathrm{mmol})$ was added to the flask and the mixture was let to stir for 5 min under an atmosphere of $\mathrm{N}_{2}$. TMSCl (3.34 mL, 26.7 mmol) was then added dropwise to the reaction flask. The reaction was then refluxed for $3 \mathrm{~h}$. After reflux, the solvent was evaporated in vacuo giving a white fluffy solid (1.98 g, $81 \%$ yield, pure).

${ }^{1} \mathrm{H} \mathrm{NMR}\left(400 \mathrm{MHz}, \mathrm{CDCl}_{3}\right) \delta=9.43(\mathrm{bs}, 2 \mathrm{H}), 3.93(\mathrm{t}, J=5.2 \mathrm{~Hz}, 2 \mathrm{H}), 3.08(\mathrm{t}, J=5.2$ $\mathrm{Hz}, 2 \mathrm{H}), 2.74(\mathrm{t}, J=5.2 \mathrm{~Hz}, 3 \mathrm{H}), 0.14(\mathrm{~s}, 9 \mathrm{H})$.

${ }^{13} \mathrm{C}$ NMR $\left(100 \mathrm{MHz}, \mathrm{CDCl}_{3}\right) \delta=57.7,50.6,33.3,-0.5$.

Anal. Calcd for $\mathrm{C}_{6} \mathrm{H}_{18} \mathrm{CINOSi} \cdot \mathrm{H}_{2} \mathrm{O}: \mathrm{C}, 35.72 ; \mathrm{H}, 9.99 ; \mathrm{N}, 6.94 \%$. Found: $\mathrm{C}, 35.56 ; \mathrm{H}$, $9.67 ; \mathrm{N}, 9.02 \%$. 

amide (6)

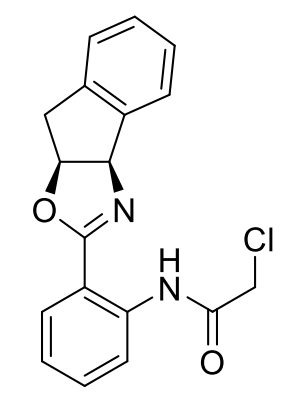

Molecular weight: $326.78 \mathrm{~g} \mathrm{~mol}^{-1}$

The solution of $5(0.50 \mathrm{~g}, 2.00 \mathrm{mmol})$ and triethylamine $(0.42 \mathrm{~mL}, 3.00 \mathrm{mmol})$ in DCM $(25 \mathrm{~mL})$ was placed into an ice bath and stirred for $30 \mathrm{~min}$. 2-Chloroacetyl chloride $(0.17$ $\mathrm{mL}, 2.20 \mathrm{mmol}$ ) was then added dropwise for $5 \mathrm{~min}$ to the stirring solution. Upon the completion of addition, the contents of the reaction vessel were stirred for $24 \mathrm{~h}$ at RT. The colour of the solution changed from yellow to dark brown with white precipitate over the course of the reaction. The solution was gravity filtered. Hexanes $(10 \mathrm{~mL})$ and then $\mathrm{Et}_{2} \mathrm{O}(5 \mathrm{~mL})$ were used to crash the product out of DCM solution. The product was isolated as peachy crystalline solid after filtration $\left(0.56 \mathrm{~g}, 86 \%\right.$ yield; pure): $\mathrm{R}_{f}=0.63$ (hexanes-EtOAc, 4:1).

${ }^{1} \mathrm{H}$ NMR $\left(400 \mathrm{MHz}, \mathrm{CDCl}_{3}\right): \delta=12.98(\mathrm{~s}, 1 \mathrm{H}), 8.72(\mathrm{dd}, J=8.4 \mathrm{~Hz}, J=0.8 \mathrm{~Hz}, 1 \mathrm{H})$, $7.89(\mathrm{dd}, J=8.0 \mathrm{~Hz}, J=1.6 \mathrm{~Hz}, 1 \mathrm{H}), 7.51-7.57(\mathrm{~m}, 1 \mathrm{H}), 7.47$ (ddd, $J=8.8 \mathrm{~Hz}, J=7.6$ $\mathrm{Hz}, J=2.0 \mathrm{~Hz}, 1 \mathrm{H}), 7.25-7.35(\mathrm{~m}, 2 \mathrm{H}), 7.13(\mathrm{td}, J=7.6 \mathrm{~Hz}, J=0.8 \mathrm{~Hz}, 1 \mathrm{H}), 5.86(\mathrm{~d}, J$ $=8.0,1 \mathrm{H}$ ), 5.47 (ddd, $J=8.4 \mathrm{~Hz}, J=7.2 \mathrm{~Hz}, J=2.0 \mathrm{~Hz}, 1 \mathrm{H}$ ), 4.25 (q, J = $14.8 \mathrm{~Hz}, 2$ H), 3.50-3.60 (m, $1 \mathrm{H}), 3.35-3.45(\mathrm{~m}, 1 \mathrm{H}), 1.41(\mathrm{t}, J=7.6 \mathrm{~Hz}, 1 \mathrm{H})$.

${ }^{13} \mathrm{C} \mathrm{NMR}\left(100 \mathrm{MHz}, \mathrm{CDCl}_{3}\right): \delta=165.8,163.8,141.4,139.7,139.0,132.8,129.5,129.0$, $127.8,125.8,125.6,123.4,120.3,114.2,82.4,76.5,43.7,39.8$. 
Anal. Calcd for $\mathrm{C}_{18} \mathrm{H}_{15} \mathrm{CIN}_{2} \mathrm{O}_{2}: \mathrm{C}, 66.16 ; \mathrm{H}, 4.63 ; \mathrm{N}, 8.57 \%$. Found: $\mathrm{C}, 65.88 ; \mathrm{H}, 4.60 ; \mathrm{N}$, $8.50 \%$.

\section{Synthesis of $N$-methyl-2-((trimethylsilyl)oxy)ethan-1-aminium chloride (7)}

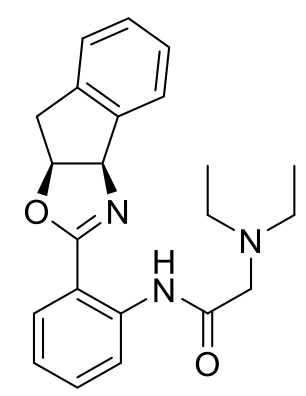

Molecular weight: $363.46 \mathrm{~g} \mathrm{~mol}^{-1}$

Compound $6(0.20 \mathrm{~g}, 0.61 \mathrm{mmol})$ was added to the stirring solution of $\mathrm{K}_{2} \mathrm{CO}_{3}(0.17 \mathrm{~g}$, $1.22 \mathrm{mmol})$ and diethylamine $(0.063 \mathrm{~mL}, 0.610 \mathrm{mmol})$ in $\mathrm{MeCN}(15.0 \mathrm{~mL})$. An orangecoloured solution was then heated to reflux temperature $\left(\sim 80^{\circ} \mathrm{C}\right)$. The reaction progress was monitored by TLC, and the reflux was stopped after $48 \mathrm{~h}$. The reaction mixture appeared dark brown with light brown precipitate. After it cooled down to RT, it was gravity filtered and the solution was left to evaporate. After evaporation the compound appeared brown in colour and waxy in composition. The compound was purified by recrystallization with EtOAc $\left(0.12 \mathrm{~g}, 55 \%\right.$ yield, crude): $\mathrm{R}_{f}=0.42$ (hexanes-EtOAc, 4:1).

${ }^{1} \mathrm{H}$ NMR $\left(400 \mathrm{MHz}, \mathrm{CDCl}_{3}\right): \delta=12.54(\mathrm{~s}, 1 \mathrm{H}), 8.81(\mathrm{~d}, J=8.4 \mathrm{~Hz}, 1 \mathrm{H}), 7.85(\mathrm{dd}, J=$ 7.6 Hz, J = 1.2 Hz, $1 \mathrm{H}), 7.51-7.38(\mathrm{~m}, 2 \mathrm{H}), 7.30-7.22(\mathrm{~m}, 3 \mathrm{H}),(\mathrm{t}, J=7.6 \mathrm{~Hz}, 1 \mathrm{H}), 5.80$ $(\mathrm{d}, J=8.0 \mathrm{~Hz}, 1 \mathrm{H}), 5.41(\mathrm{td}, J=6.8 \mathrm{~Hz}, J=1.6 \mathrm{~Hz}, 1 \mathrm{H}), 3.56-3.47(\mathrm{~m}, 1 \mathrm{H}), 3.42-3.34$ (m, $1 \mathrm{H}), 3.27(\mathrm{~s}, 2 \mathrm{H}), 2.75(\mathrm{q}, J=7.2 \mathrm{~Hz}, 4 \mathrm{H}), 1.14(\mathrm{t}, J=7.2 \mathrm{~Hz}, 6 \mathrm{H})$. 


\subsection{PALLADIUM COMPLEXES}

\section{Synthesis of 9a}

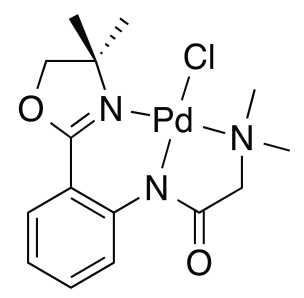

Molecular weight: $416.21 \mathrm{~g} \mathrm{~mol}^{-1}$

The solution of $3 \mathrm{a}(0.10 \mathrm{~g}, 0.36 \mathrm{mmol})$ in $\mathrm{MeOH}(5.0 \mathrm{~mL})$ was cooled in the ice bath for $5 \mathrm{~min}$. Then the $0.1135 \mathrm{M}$ solution of $\mathrm{Li}_{2} \mathrm{PdCl}_{4}(3.20 \mathrm{~mL}, 0.36 \mathrm{mmol})$ was added dropwise. The orange solution was stirred at RT for $24 \mathrm{~h}$. The solvent was removed in vacuo and the orange compound was redissolved in $\mathrm{DCM}(5.0 \mathrm{~mL})$ and filtered through Celite. The compound was isolated as orange solid $(0.12 \mathrm{~g}, 82 \%$ yield; pure).

IR (KBr): 2956, 2911, 1646, 1611, 1488, 1362, 1273, 1167, 1086, 966, 865, $756 \mathrm{~cm}^{-1}$.

${ }^{1} \mathrm{H} \mathrm{NMR}\left(400 \mathrm{MHz}, \mathrm{CDCl}_{3}\right): \delta=8.34(\mathrm{dd}, J=8.4 \mathrm{~Hz}, J=0.8 \mathrm{~Hz}, 1 \mathrm{H}), 7.70(\mathrm{dd}, J=8.0$ $\mathrm{Hz}, J=1.6 \mathrm{~Hz}, 1 \mathrm{H}$ ), 7.40 (ddd, $J=8.8 \mathrm{~Hz}, J=7.2 \mathrm{~Hz}, J=1.6 \mathrm{~Hz}, 1 \mathrm{H}$ ), 6.99 (ddd, $J=$ $8.0 \mathrm{~Hz}, J=7.2 \mathrm{~Hz}, J=0.8 \mathrm{~Hz}, 1 \mathrm{H}), 4.21(\mathrm{~s}, 2 \mathrm{H}), 3.68(\mathrm{~s}, 2 \mathrm{H}), 2.70(\mathrm{~s}, 6 \mathrm{H}), 1.72(\mathrm{~s}, 6$ H).

${ }^{13} \mathrm{C} \mathrm{NMR}\left(100 \mathrm{MHz}, \mathrm{CDCl}_{3}\right): \delta=175.1,162.6,144.8,133.2,129.8,123.4,122.0,116.5$, $81.5,71.2,70.7,52.2,27.9$.

Anal. Calcd for $\mathrm{C}_{15} \mathrm{H}_{20} \mathrm{ClN}_{3} \mathrm{O}_{2} \mathrm{Pd}$ : $\mathrm{C}, 43.29 ; \mathrm{H}, 4.84 ; \mathrm{N}, 10.10 \%$. Found: $\mathrm{C}, 43.24 ; \mathrm{H}$, $4.92 ; \mathrm{N}, 9.99 \%$. 


\section{Synthesis of $9 b$}

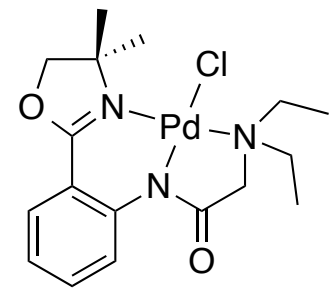

Molecular weight: $444.27 \mathrm{~g} \mathrm{~mol}^{-1}$

The compound was prepared and purified similarly as for $9 \mathrm{a}$ from $3 \mathrm{~b}(0.24 \mathrm{~g}, 0.79$ $\mathrm{mmol}$ ) and $7.9 \times 10^{-2} \mathrm{M} \mathrm{Li}_{2} \mathrm{PdCl}_{4}(10.0 \mathrm{~mL}, 0.79 \mathrm{mmol})$. The compound was isolated as orange solid ( $0.18 \mathrm{~g}, 52 \%$ yield; pure).

${ }^{1} \mathrm{H}$ NMR $\left(400 \mathrm{MHz}, \mathrm{CDCl}_{3}\right): \delta=8.30(\mathrm{~d}, J=8.4 \mathrm{~Hz}, 1 \mathrm{H}), 7.65(\mathrm{~d}, J=7.6 \mathrm{~Hz}, 1 \mathrm{H}), 7.37$ $(\mathrm{t}, J=7.6 \mathrm{~Hz}, 1 \mathrm{H}), 6.96(\mathrm{t}, J=7.6 \mathrm{~Hz}, 1 \mathrm{H}), 4.21(\mathrm{~s}, 2 \mathrm{H}), 3.61(\mathrm{~s}, 2 \mathrm{H}), 3.23(\mathrm{dq}, J=$ $13.6 \mathrm{~Hz}, J=6.8 \mathrm{~Hz}, 2 \mathrm{H}), 2.43(\mathrm{dq}, J=13.6 \mathrm{~Hz}, J=6.8 \mathrm{~Hz}, 2 \mathrm{H}), 1.73(\mathrm{~s}, 6 \mathrm{H}), 1.65(\mathrm{t}, J$ $=6.8 \mathrm{~Hz}, 6 \mathrm{H})$.

${ }^{13} \mathrm{C}$ NMR $\left(100 \mathrm{MHz}, \mathrm{CDCl}_{3}\right): \delta=177.3,162.4,144.7,132.9,129.4,123.2,121.6,116.4$, $81.6,70.6,63.6,56.6,27.9,12.4$.

Anal. Calcd for $\mathrm{C}_{17} \mathrm{H}_{24} \mathrm{CIN}_{3} \mathrm{O}_{2} \mathrm{Pd} \cdot 1 / 2\left(\mathrm{H}_{2} \mathrm{O}\right)$ : C, 43.33; $\mathrm{H}, 5.77 ; \mathrm{N}, 8.92 \%$. Found: $\mathrm{C}, 43.57$; $H, 5.47 ; \mathrm{N}, 8.52 \%$. 


\section{Synthesis of $9 \mathrm{c}$}

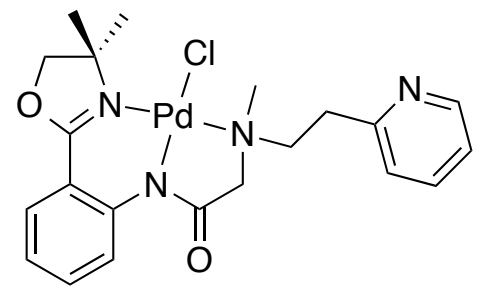

Molecular weight: $507.33 \mathrm{~g} \mathrm{~mol}^{-1}$

The compound was prepared and purified similarly as for 9a from $3 \mathrm{c}(0.34 \mathrm{~g}, 0.92$ $\mathrm{mmol}$ ) and $9.3 \times 10^{-2} \mathrm{M} \mathrm{Li}_{2} \mathrm{PdCl}_{4}(10.0 \mathrm{~mL}, 0.92 \mathrm{mmol})$. The compound was purified using preparative TLC (\% Acetone as eluent, $\left.R_{f}=0.62\right)$ and isolated as orange solid ( $0.21 \mathrm{~g}, 45 \%$ yield; pure).

${ }^{1} \mathrm{H}$ NMR $\left(400 \mathrm{MHz}, \mathrm{CDCl}_{3}\right): \delta=9.12(\mathrm{~d}, J=5.6 \mathrm{~Hz}, 1 \mathrm{H}), 8.49(\mathrm{~d}, J=8.6 \mathrm{~Hz}, 1 \mathrm{H})$, 7.79-7.66 (m, 3 H), 7.48-7.32 (m, 2 H), 7.05-6.96 (m, 1 H), 5.22-5.09 (m, 1 H), 4.91-4.80 (m, $1 \mathrm{H}), 4.79-4.69(\mathrm{~m}, 1 \mathrm{H}), 4.35-4.20(\mathrm{~m}, 2 \mathrm{H}), 3.82-3.73(\mathrm{~m}, 1 \mathrm{H})$, 3.56-3.42 $(\mathrm{m}, 1 \mathrm{H})$, 3.16-3.06 (m, $1 \mathrm{H}), 2.98(\mathrm{~s}, 3 \mathrm{H}), 1.83(\mathrm{~s}, 3 \mathrm{H}), 1.76(\mathrm{~s}, 3 \mathrm{H})$.

${ }^{13} \mathrm{C} \mathrm{NMR}\left(100 \mathrm{MHz}, \mathrm{CDCl}_{3}\right): \delta=175.4,162.6,159.8,153.1,144.7,138.9,133.2,129.5$, $127.3,123.7,121.9,116.4,81.6,70.7,68.4,62.3,52.6,51.3,39.0,28.1,27.9$.

Anal. Calcd for $\mathrm{C}_{21} \mathrm{H}_{25} \mathrm{ClN}_{4} \mathrm{O}_{2} \mathrm{Pd} \cdot 2\left(\mathrm{CH}_{2} \mathrm{Cl}_{2}\right)$ : C, 40.79; $\mathrm{H}, 4.32 ; \mathrm{N}, 8.27 \%$. Found: $\mathrm{C}$ 41.34, H 4.53, N 8.69\%. 


\section{Synthesis of $9 d$}

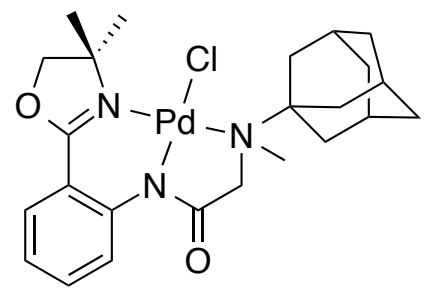

Molecular weight: $536.41 \mathrm{~g} \mathrm{~mol}^{-1}$

The compound was prepared and purified similarly as for 9a from $\mathbf{3 d}(0.03 \mathrm{~g}, 0.08$ $\mathrm{mmol})$ and $7.9 \times 10^{-2} \mathrm{M} \mathrm{Li}_{2} \mathrm{PdCl}_{4}(0.96 \mathrm{~mL}, 0.08 \mathrm{mmol})$. The compound was isolated as orange solid ( $0.04 \mathrm{~g}, 80 \%$ yield; pure).

${ }^{1} \mathrm{H}$ NMR $\left(400 \mathrm{MHz}, \mathrm{CDCl}_{3}\right): \delta=8.07(\mathrm{~d}, J=8.4 \mathrm{~Hz}, 1 \mathrm{H}), 7.69(\mathrm{~d}, J=8.0 \mathrm{~Hz}, 1 \mathrm{H}), 7.41$ (t, J = 7.2 Hz, $1 \mathrm{H}), 7.01(\mathrm{t}, J=7.6 \mathrm{~Hz}, 1 \mathrm{H}), 4.35-4.12(\mathrm{~m}, 2 \mathrm{H}), 3.91-3.84(\mathrm{~m}, 2 \mathrm{H}), 2.85$ (s, $3 \mathrm{H}), 2.23-2.08(\mathrm{~m}, 7 \mathrm{H}), 1.88(\mathrm{~s}, 3 \mathrm{H}), 1.70-1.56(\mathrm{~m}, 15 \mathrm{H})$.

${ }^{13} \mathrm{C} \mathrm{NMR}\left(100 \mathrm{MHz}, \mathrm{CDCl}_{3}\right): \delta=177.0,162.7,144.7,133.2,129.4,123.0,121.7,117.4$, 82.0, 70.9, 67.1, 64.2, 47.7, 39.0, 36.1, 30.2, 28.7, 27.7.

Anal. Calcd for $\mathrm{C}_{24} \mathrm{H}_{32} \mathrm{ClN}_{3} \mathrm{O}_{2} \mathrm{Pd} \cdot 1 / 2\left(\mathrm{CH}_{2} \mathrm{Cl}_{2}\right): \mathrm{C}, 46.14 ; \mathrm{H}, 5.31 ; \mathrm{N}, 6.33 \%$. Found: $\mathrm{C}$, 46.30; H, 5.48; N, 6.15\%. 


\section{Synthesis of $9 e$}

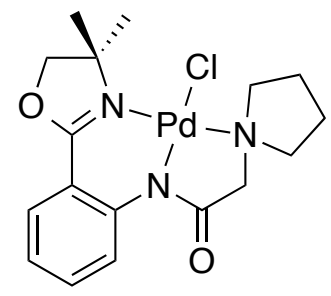

Molecular weight: $442.25 \mathrm{~g} \mathrm{~mol}^{-1}$

The compound was prepared and purified similarly as for $9 \mathrm{a}$ from $3 \mathbf{e}(0.20 \mathrm{~g}, 0.66$ $\mathrm{mmol}$ ) and $0.1135 \mathrm{M} \mathrm{Li}_{2} \mathrm{PdCl}_{4}(5.85 \mathrm{~mL}, 0.66 \mathrm{mmol})$. The compound was isolated as orange solid ( $0.18 \mathrm{~g}, 62 \%$ yield; pure).

${ }^{1} \mathrm{H} \mathrm{NMR}\left(400 \mathrm{MHz}, \mathrm{CDCl}_{3}\right): \delta=8.27(\mathrm{~d}, J=8.4 \mathrm{~Hz}, 1 \mathrm{H}), 7.70(J=8.0 \mathrm{~Hz}, J=1.6 \mathrm{~Hz}, 1$ H), 7.40 (ddd, $J=8.8 \mathrm{~Hz}, J=7.2 \mathrm{~Hz}, J=1.6 \mathrm{~Hz}, 1 \mathrm{H}$ ), 6.99 (dd, $J=7.6 \mathrm{~Hz}, J=7.6 \mathrm{~Hz}$, $1 \mathrm{H}), 4.20$ (s, $2 \mathrm{H}), 3.83-3.71(\mathrm{~m}, 4 \mathrm{H}), 2.75-2.64(\mathrm{~m}, 2 \mathrm{H})$, 2.12-2.01 (m, $2 \mathrm{H}), 1.91-1.81$ (m, $2 \mathrm{H}), 1.72(\mathrm{~s}, 6 \mathrm{H})$.

${ }^{13} \mathrm{C} \mathrm{NMR}\left(100 \mathrm{MHz}, \mathrm{CDCl}_{3}\right): \delta=175.2,162.4,144.6,132.9,129.6,123.3,121.7,116.6$, $81.4,70.6,68.0,60.1,27.8,22.2$.

Anal. Calcd for $\mathrm{C}_{17} \mathrm{H}_{22} \mathrm{CIN}_{3} \mathrm{O}_{2} \mathrm{Pd}$ : C, 45.25; $\mathrm{H}, 5.14 ; \mathrm{N}, 9.31 \%$. Found: $\mathrm{C}, 45.45 ; \mathrm{H}, 4.97$; N, $8.95 \%$. 


\section{Synthesis of $9 \mathrm{~g}$}

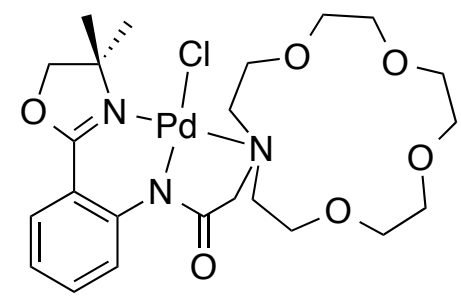

\section{Molecular weight: $590.41 \mathrm{~g} \mathrm{~mol}^{-1}$}

The compound was prepared and purified similarly as for 9a from $\mathbf{3 g}(0.10 \mathrm{~g}, 0.20$ $\mathrm{mmol}$ ) and $0.1135 \mathrm{M} \mathrm{Li}_{2} \mathrm{PdCl}_{4}(1.75 \mathrm{~mL}, 0.20 \mathrm{mmol})$. The compound was isolated as orange solid $(0.11 \mathrm{~g}, 93 \%$ yield; pure).

IR (KBr): 2871, 1636, 1617, 1364, 1272, 1125, 1085, 755, $732 \mathrm{~cm}^{-1}$.

${ }^{1} \mathrm{H}$ NMR $\left(400 \mathrm{MHz}, \mathrm{CDCl}_{3}\right): \delta=8.28(\mathrm{dd}, J=8.4 \mathrm{~Hz}, J=0.8 \mathrm{~Hz}, 1 \mathrm{H}), 7.65(\mathrm{dd}, J=8.0$ $\mathrm{Hz}, J=1.6 \mathrm{~Hz}, 1 \mathrm{H}), 7.37$ (ddd, $J=8.8 \mathrm{~Hz}, J=7.2 \mathrm{~Hz}, J=1.6 \mathrm{~Hz}, 1 \mathrm{H}$ ), 6.96 (ddd, $J=$ $8.4 \mathrm{~Hz}, J=7.2 \mathrm{~Hz}, J=1.2 \mathrm{~Hz}, 1 \mathrm{H}), 4.65(\mathrm{~s}, 2 \mathrm{H}), 4.35-4.25(\mathrm{~m}, 2 \mathrm{H}), 4.20(\mathrm{~s}, 2 \mathrm{H})$, 4.12-4.02 (m, $2 \mathrm{H}), 3.75-3.55(\mathrm{~m}, 12 \mathrm{H}), 3.42-3.35(\mathrm{~m}, 4 \mathrm{H}), 1.72(\mathrm{~s}, 6 \mathrm{H})$.

${ }^{13} \mathrm{C}$ NMR $\left(100 \mathrm{MHz}, \mathrm{CDCl}_{3}\right): \delta=177.2,162.6,145.0,133.0,129.4,123.7,121.6,116.5$, $81.7,71.0,70.8,70.6,70.5,68.8,60.1,28.0$.

Anal. Calcd for $\mathrm{C}_{23} \mathrm{H}_{34} \mathrm{CIN}_{3} \mathrm{O}_{6} \mathrm{Pd} \cdot 1 / 2\left(\mathrm{CH}_{3} \mathrm{OH}\right): \mathrm{C}, 46.54 ; \mathrm{H}, 5.98 ; \mathrm{N}, 6.93 \%$. Found: $\mathrm{C}$, 47.63; H, 6.38; N, 6.91\%. 


\section{Synthesis of $9 \mathrm{~h}$}

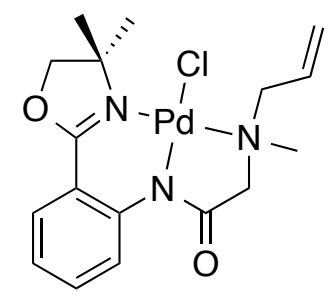

\section{Molecular weight: $442.25 \mathrm{~g} \mathrm{~mol}^{-1}$}

The compound was prepared and purified similarly as for $9 \mathrm{a}$ from $3 \mathrm{~h}(0.16 \mathrm{~g}, 0.51$ $\mathrm{mmol}$ ) and $0.1135 \mathrm{M} \mathrm{Li}_{2} \mathrm{PdCl}_{4}(4.53 \mathrm{~mL}, 0.51 \mathrm{mmol})$. The compound was isolated as orange solid ( $0.18 \mathrm{~g}, 78 \%$ yield; pure).

IR (KBr): 2954, 2918, 1636, 1618, 1486, 1356, 1324, 1271, 1085, $753 \mathrm{~cm}^{-1}$.

${ }^{1} \mathrm{H} \mathrm{NMR}\left(400 \mathrm{MHz}, \mathrm{CDCl}_{3}\right): \delta=8.31(\mathrm{dd}, J=8.4 \mathrm{~Hz}, J=0.8 \mathrm{~Hz}, 1 \mathrm{H}), 7.67(\mathrm{dd}, J=8.0$ $\mathrm{Hz}, J=1.6 \mathrm{~Hz}, 1 \mathrm{H}), 7.38(\mathrm{ddd}, J=8.8 \mathrm{~Hz}, J=7.2 \mathrm{~Hz}, J=1.6 \mathrm{~Hz}, 1 \mathrm{H}$ ), 6.97 (ddd, $J=$ $8.4 \mathrm{~Hz}, J=7.2 \mathrm{~Hz}, J=1.2 \mathrm{~Hz}, 1 \mathrm{H}$ ), 6.64 (dddd, $J=17.2 \mathrm{~Hz}, J=10.0 \mathrm{~Hz}, J=8.4 \mathrm{~Hz}, J$ $=5.2 \mathrm{~Hz}, 1 \mathrm{H}), 5.48(\mathrm{~d}, J=10.0 \mathrm{~Hz}, 1 \mathrm{H}), 5.37(\mathrm{dd}, J=17.2 \mathrm{~Hz}, J=0.8 \mathrm{~Hz}, 1 \mathrm{H}), 4.27-$ $4.15(\mathrm{~m}, 2 \mathrm{H}), 3.99(\mathrm{~d}, J=16.0 \mathrm{~Hz}, 1 \mathrm{H}), 3.89(\mathrm{dd}, J=12.8 \mathrm{~Hz}, J=5.2 \mathrm{~Hz}, 1 \mathrm{H}), 3.31(\mathrm{~d}$, $J=16.0 \mathrm{~Hz}, 1 \mathrm{H}), 2.78(\mathrm{~s}, 3 \mathrm{H}), 2.74(\mathrm{dd}, J=12.8 \mathrm{~Hz}, J=8.4 \mathrm{~Hz}, 1 \mathrm{H}), 1.77(\mathrm{~s}, 3 \mathrm{H})$, $1.68(\mathrm{~s}, 3 \mathrm{H})$.

${ }^{13} \mathrm{C}$ NMR $\left(100 \mathrm{MHz}, \mathrm{CDCl}_{3}\right): \delta=175.9,162.6,144.8,133.1,131.5,129.6,123.4,123.3$, $121.9,116.4,81.6,70.7,66.9,65.5,50.8,28.1,27.8$.

Anal. Calcd for $\mathrm{C}_{17} \mathrm{H}_{22} \mathrm{ClN}_{3} \mathrm{O}_{2} \mathrm{Pd}$ : C, 46.17; $\mathrm{H}, 5.01 ; \mathrm{N}, 9.50 \%$. Found: $\mathrm{C}, 46.30 ; \mathrm{H}, 5.31$; N, $9.32 \%$. 


\section{Synthesis of $9 i$}

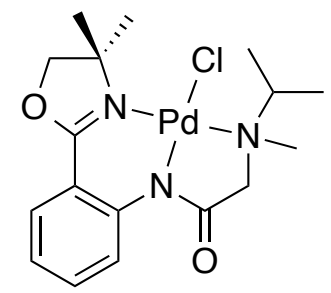

Molecular weight: $444.27 \mathrm{~g} \mathrm{~mol}^{-1}$

The compound was prepared and purified similarly as for $9 \mathbf{a}$ from $3 \mathbf{i}(0.06 \mathrm{~g}, 0.20 \mathrm{mmol})$ and $7.9 \times 10^{-2} \mathrm{M} \mathrm{Li}_{2} \mathrm{PdCl}_{4}(2.53 \mathrm{~mL}, 0.20 \mathrm{mmol})$. The compound was isolated as orange solid $(0.07 \mathrm{~g}, 77 \%$ yield; pure).

${ }^{1} \mathrm{H}$ NMR $\left(400 \mathrm{MHz}, \mathrm{CDCl}_{3}\right): \delta=8.34(\mathrm{dd}, J=8.8 \mathrm{~Hz}, J=0.8 \mathrm{~Hz}, 1 \mathrm{H}), 7.69(\mathrm{~J}=8.0 \mathrm{~Hz}$, $J=1.6 \mathrm{~Hz}, 1 \mathrm{H}$ ), 7.41 (ddd, $J=8.8 \mathrm{~Hz}, J=7.2 \mathrm{~Hz}, J=1.6 \mathrm{~Hz}, 1 \mathrm{H}$ ), 7.00 (ddd, $J=8.0$ $\mathrm{Hz}, J=7.2 \mathrm{~Hz}, J=0.8 \mathrm{~Hz}, 1 \mathrm{H}), 4.28-4.20(\mathrm{~m}, 2 \mathrm{H}), 3.90-3.83(\mathrm{~m}, 1 \mathrm{H}), 3.60$ (sept, $J=$ $6.8 \mathrm{~Hz}, 1 \mathrm{H}), 3.45-3.39(\mathrm{~m}, 1 \mathrm{H}), 2.84(\mathrm{~s}, 3 \mathrm{H}), 1.79(\mathrm{~s}, 3 \mathrm{H}), 1.74(\mathrm{~s}, 3 \mathrm{H}), 1.71(\mathrm{~d}, J=$ $6.8 \mathrm{~Hz}, 3 \mathrm{H}), 1.26(\mathrm{~d}, J=6.8 \mathrm{~Hz}, 3 \mathrm{H})$.

${ }^{13} \mathrm{C}$ NMR $\left(100 \mathrm{MHz}, \mathrm{CDCl}_{3}\right): \delta=176.8,162.4,144.6,132.9,129.4,123.3,121.7,116.5$, $81.5,70.5,62.3,59.5,47.6,27.9,27.7,20.5,15.7$.

Anal. Calcd for $\mathrm{C}_{17} \mathrm{H}_{24} \mathrm{CIN}_{3} \mathrm{O}_{2} \mathrm{Pd}$ : C, 45.96; $\mathrm{H}, 5.45 ; \mathrm{N}, 9.46 \%$. Found: $\mathrm{C}, 46.56 ; \mathrm{H}, 5.52$; N, $9.26 \%$. 


\section{Synthesis of 9j}

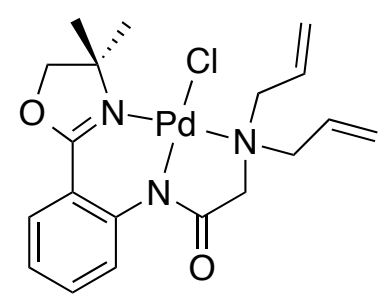

Molecular weight: $468.29 \mathrm{~g} \mathrm{~mol}^{-1}$

The compound was prepared and purified similarly as for $9 \mathbf{a}$ from $\mathbf{3 j}(0.21 \mathrm{~g}, 0.63 \mathrm{mmol})$ and $6.3 \times 10^{-2} \mathrm{M} \mathrm{Li}_{2} \mathrm{PdCl}_{4}(10.0 \mathrm{~mL}, 0.63 \mathrm{mmol})$. The compound was isolated as orange solid ( $0.12 \mathrm{~g}, 42 \%$ yield; pure).

${ }^{1} \mathrm{H} \mathrm{NMR}\left(400 \mathrm{MHz}, \mathrm{CDCl}_{3}\right): \delta=8.24(\mathrm{dd}, J=8.8 \mathrm{~Hz}, J=0.8 \mathrm{~Hz}, 1 \mathrm{H}), 7.66(\mathrm{dd}, J=8.0$ $\mathrm{Hz}, J=1.6 \mathrm{~Hz}, 1 \mathrm{H}), 7.38(\mathrm{ddd}, J=8.8 \mathrm{~Hz}, J=7.2 \mathrm{~Hz}, J=1.6 \mathrm{~Hz}, 1 \mathrm{H}), 6.97$ (ddd, $J=$ $8.0 \mathrm{~Hz}, J=7.2 \mathrm{~Hz}, J=0.8 \mathrm{~Hz}, 1 \mathrm{H}$ ), 6.73 (dddd, $J=17.2 \mathrm{~Hz}, J=10.4 \mathrm{~Hz}, J=8.8 \mathrm{~Hz}, J$ $=5.6 \mathrm{~Hz}, 2 \mathrm{H}), 5.47(\mathrm{~d}, J=10.0 \mathrm{~Hz}, 2 \mathrm{H}), 5.39(\mathrm{~d}, J=17.2 \mathrm{~Hz}, 2 \mathrm{H}), 4.23(\mathrm{~s}, 2 \mathrm{H}), 3.95$ (dd, $J=12.8 \mathrm{~Hz}, J=5.6 \mathrm{~Hz}, 2 \mathrm{H}), 3.66(\mathrm{~s}, 2 \mathrm{H}), 2.89(\mathrm{dd}, J=12.8 \mathrm{~Hz}, J=8.8 \mathrm{~Hz}, 2 \mathrm{H})$, $1.75(\mathrm{~s}, 6 \mathrm{H})$.

${ }^{13} \mathrm{C} \mathrm{NMR}\left(100 \mathrm{MHz}, \mathrm{CDCl}_{3}\right): \delta=176.8,162.7,144.7,133.1,131.6,129.4,123.3,123.1$, $121.7,116.4,81.7,70.7,64.9,63.4,28.0$.

Anal. Calcd for $\mathrm{C}_{19} \mathrm{H}_{24} \mathrm{ClN}_{3} \mathrm{O}_{2} \mathrm{Pd}$ : C, 48.73; $\mathrm{H}, 5.17 ; \mathrm{N}, 8.97 \%$. Found: $\mathrm{C}, 48.33 ; \mathrm{H}, 5.19$; N, $8.80 \%$. 


\section{Synthesis of $9 k$}

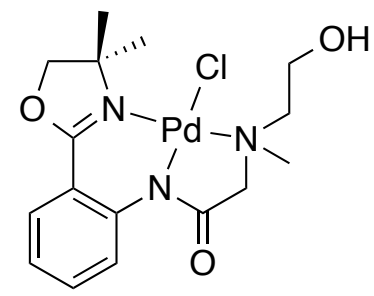

\section{Molecular weight: $446.24 \mathrm{~g} \mathrm{~mol}^{-1}$}

The compound was prepared and purified similarly as for 9a from 3k $(0.063 g, 0.206$ $\mathrm{mmol}$ ) and $7.9 \times 10^{-2} \mathrm{M} \mathrm{Li}_{2} \mathrm{PdCl}_{4}(2.60 \mathrm{~mL}, 0.205 \mathrm{mmol})$. The compound was isolated as orange solid ( $0.09 \mathrm{~g}, 95 \%$ yield; pure).

${ }^{1} \mathrm{H}$ NMR $\left(400 \mathrm{MHz}, \mathrm{CDCl}_{3}\right): \delta=8.29(\mathrm{dd}, J=8.8 \mathrm{~Hz}, J=0.8 \mathrm{~Hz}, 1 \mathrm{H}), 7.69(\mathrm{dd}, J=8.0$ $\mathrm{Hz}, J=1.6 \mathrm{~Hz}, 1 \mathrm{H}$ ), 7.40 (ddd, $J=8.8 \mathrm{~Hz}, J=7.2 \mathrm{~Hz}, J=1.6 \mathrm{~Hz}, 1 \mathrm{H}$ ), 7.00 (ddd, $J=$ $8.0 \mathrm{~Hz}, J=7.2 \mathrm{~Hz}, J=0.8 \mathrm{~Hz}, 1 \mathrm{H}), 4.50-4.38(\mathrm{~m}, 1 \mathrm{H}), 4.30-4.12(\mathrm{~m}, 3 \mathrm{H}), 3.90-3.70$ (m, $2 \mathrm{H}), 3.52(\mathrm{t}, J=6.8 \mathrm{~Hz}, 1 \mathrm{H})$, 2.92-2.82 (m, $1 \mathrm{H}), 2.76(\mathrm{~s}, 3 \mathrm{H})$, 2.75-2.70 (m, $1 \mathrm{H})$, $1.73(\mathrm{~s}, 3 \mathrm{H}), 1.67$ (s, $3 \mathrm{H})$.

${ }^{13} \mathrm{C} \mathrm{NMR}\left(100 \mathrm{MHz}, \mathrm{CDCl}_{3}\right): \delta=174.8,162.6,144.4,133.1,129.6,123.4,122.0,116.4$ $81.5,70.5,70.2,65.1,60.2,50.9,27.9,27.6$.

Anal. Calcd for $\mathrm{C}_{16} \mathrm{H}_{22} \mathrm{CIN}_{3} \mathrm{O}_{3} \mathrm{Pd} \cdot 1 / 2 \mathrm{CH}_{2} \mathrm{Cl}_{2}$ ): $\mathrm{C}, 40.55 ; \mathrm{H}, 4.74 ; \mathrm{N}, 8.60 \%$. Found: $\mathrm{C}$, 41.04; H, 4.40; N, 8.14\%.

\section{Synthesis of $\mathrm{PdCl}_{2}(\mathrm{MeCN})_{2}$}

$\mathrm{PdCl}_{2}(0.51 \mathrm{~g}, 2.88 \mathrm{mmol})$ was dissolved in $\mathrm{MeCN}(60.0 \mathrm{~mL})$ and refluxed for $1.5 \mathrm{~h}$ until the solution got saturated. The reaction mixture was hot gravity filtered and the bright orange filtrate was put on ice. Orange crystals crashed out of the solution and were vacuum filtered $\left(0.65 \mathrm{~g}, 89 \%\right.$ yield; pure). ${ }^{1} \mathrm{H}-\mathrm{NMR}$ spectrum matches the literature. ${ }^{69}$ 


\section{Synthesis of 91}

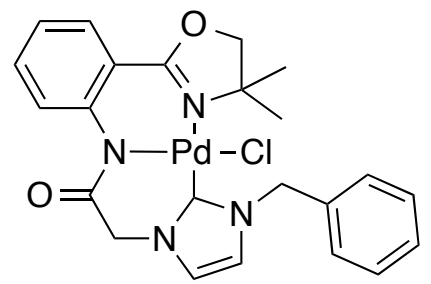

Molecular weight: $530.34 \mathrm{~g} \mathrm{~mol}^{-1}$

$\mathrm{Ag}_{2} \mathrm{O}(0.028 \mathrm{~g}, 0.12 \mathrm{mmol})$ and $3 \mathrm{I}(0.100 \mathrm{~g}, 0.24 \mathrm{mmol})$ were dissolved in DCM (10.0 $\mathrm{mL}$ ) and stirred at RT under $\mathrm{N}_{2}$ atmosphere for $2 \mathrm{~h}$. The reaction mixture was filtered through Celite. Then $\mathrm{PdCl}_{2}(\mathrm{MeCN})_{2}(0.062 \mathrm{~g}, 0.24 \mathrm{mmol})$ was added and the solution turned bright yellow milky colour after 2 min. The reaction was stirred at RT for $24 \mathrm{~h}$ under $\mathrm{N}_{2}$. The opaque solution was gravity filtered and the solvent was removed in vacuo. Recrystallized from DCM/hexanes (1:1) mixture as yellow wax $(0.12 \mathrm{~g}, 94 \%$ yield; pure).

${ }^{1} \mathrm{H}$ NMR $\left(400 \mathrm{MHz}, \mathrm{CDCl}_{3}\right): \delta=7.67(\mathrm{~d}, J=7.6 \mathrm{~Hz}, 1 \mathrm{H}), 7.45-7.24(\mathrm{~m}, 7 \mathrm{H}), 7.10-7.04$ $(\mathrm{m}, 1 \mathrm{H}), 7.01(\mathrm{~d}, J=1.8 \mathrm{~Hz}, 1 \mathrm{H}), 6.71(\mathrm{~d}, J=1.8 \mathrm{~Hz}, 1 \mathrm{H}), 5.78-5.70(\mathrm{~m}, 1 \mathrm{H}), 5.64-$ $5.57(\mathrm{~m}, 1 \mathrm{H})$, 5.52-5.44 (m, $1 \mathrm{H})$, 4.52-4.45 (m, $1 \mathrm{H}), 4.39-4.33(\mathrm{~m}, 1 \mathrm{H})$, 4.16-4.10 $(\mathrm{m}$, $1 \mathrm{H}), 1.79(\mathrm{~s}, 3 \mathrm{H}), 1.72(\mathrm{~s}, 3 \mathrm{H})$.

${ }^{13} \mathrm{C} \mathrm{NMR}\left(100 \mathrm{MHz}, \mathrm{CDCl}_{3}\right): \delta=171.2,163.3,136.1,132.1,129.2,128.8,128.2,127.8$, $126.8,122.8,121.6,121.2,120.6,81.8,70.0,60.4,57.5,53.9,29.7,28.6,27.1,24.4$, $21.0,14.2$. 


\section{Synthesis of $9 m$}

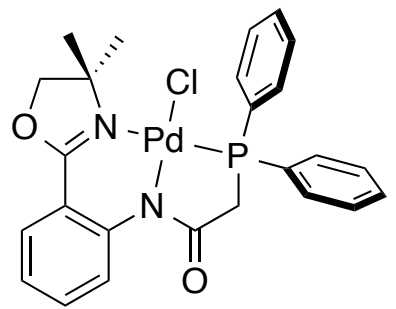

Molecular weight: $557.32 \mathrm{~g} \mathrm{~mol}^{-1}$

Compound $2(0.20 \mathrm{~g}, 0.75 \mathrm{mmol})$ was dissolved in dry THF $(10.0 \mathrm{~mL})$ and was placed into an ice bath at $-84{ }^{\circ} \mathrm{C}$ (the mixture of EtOAc/liquid $\mathrm{N}_{2}$ ). A $0.5 \mathrm{M}$ solution of $\mathrm{KPPh}_{2}$ in THF (1.50 mL, $0.75 \mathrm{mmol}$ ) was added dropwise to the stirring solution. The solution was stirred under $\mathrm{N}_{2}$ at $\mathrm{RT}$ for $24 \mathrm{~h}$, and then it was cannula transferred into the flask containing the solution of $\mathrm{PdCl}_{2}(\mathrm{MeCN})_{2}(0.195 \mathrm{~g}, 0.75 \mathrm{mmol})$ in MeCN:THF mixture (10:5 mL). Dark orange solution was stirred under $\mathrm{N}_{2}$ at RT for $24 \mathrm{~h}$. After $24 \mathrm{~h}$ the reaction mixture turned black, and was gravity filtered, giving bright orange filtrate with black precipitate. After the solvent was removed in vacuo the compound was retrieved as orange solid $(0.12 \mathrm{~g}, 96 \%$ yield, crude). The pure compound was isolated by preparative TLC $\left(R_{f}=0.18\right.$; EtOAc-hexanes, $\left.4: 1\right)$ as orange waxy solid.

${ }^{1} \mathrm{H}$ NMR $\left(400 \mathrm{MHz}, \mathrm{CDCl}_{3}\right): \delta=7.94-7.80(\mathrm{~m}, 4 \mathrm{H}), 7.71-7.62(\mathrm{~m}, 2 \mathrm{H}), 7.61-7.46(\mathrm{~m}, 5$ H), 7.28-7.19 (m, $1 \mathrm{H}), 7.01(\mathrm{t}, J=8.0 \mathrm{~Hz}, 1 \mathrm{H}), 6.81(\mathrm{~d}, J=8.4 \mathrm{~Hz}, 1 \mathrm{H}), 4.62(\mathrm{dd}, J=$ $20.0 \mathrm{~Hz}, J=15.2 \mathrm{~Hz}, 1 \mathrm{H}), 4.39-4.34(\mathrm{~m}, 1 \mathrm{H}), 4.14-4.12(\mathrm{~m}, 1 \mathrm{H}), 3.52(\mathrm{~d}, J=16.4 \mathrm{~Hz}$, $1 \mathrm{H}), 1.78(\mathrm{~s}, 3 \mathrm{H}), 1.66(\mathrm{~s}, 3 \mathrm{H})$.

${ }^{13} \mathrm{C}$ NMR $\left(100 \mathrm{MHz}, \mathrm{CDCl}_{3}\right): \delta=165.1,163.3,145.6,133.5,132.6,131.4,129.4,129.2$ 128.2, 126.2, 122.9, 120.5, 82.2, 69.9, 53.4, 44.8, 44.2, 29.7, 28.0, 27.0.

${ }^{31} \mathrm{P}$ NMR $\left(162 \mathrm{MHz}, \mathrm{CDCl}_{3}\right): \delta=50.45$. 
Anal. Calcd for $\mathrm{C}_{25} \mathrm{H}_{24} \mathrm{CIN}_{2} \mathrm{O}_{2} \mathrm{PPd} \cdot 1\left(\mathrm{CH}_{2} \mathrm{Cl}_{2}\right) \cdot 1\left(\mathrm{H}_{2} \mathrm{O}\right)$ : C, 47.30; $\mathrm{H}, 4.27 ; \mathrm{N}, 4.24 \%$. Found: C, 47.60; H, 4.21; N, 4.23\%. 


\subsection{CATALYSIS}

\section{Allylatoin of aldehydes}
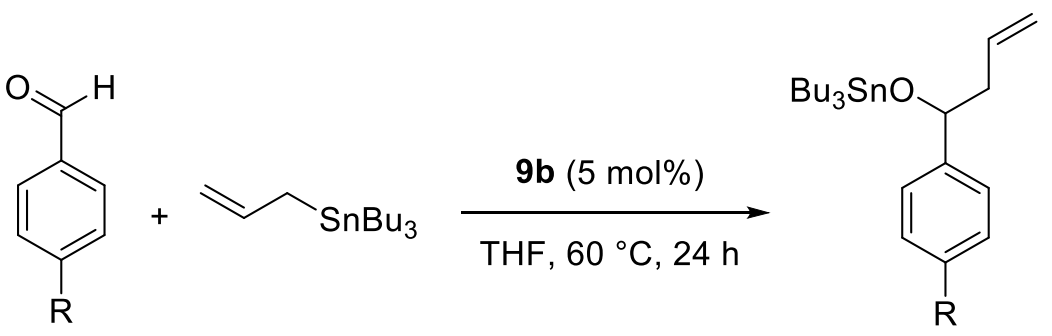

10a: $\mathrm{R}=\mathrm{NO}_{2}$

11a: $\mathrm{R}=\mathrm{NO}_{2}$

10b: $\mathrm{R}=\mathrm{OCH}_{3}$

11b: $\mathrm{R}=\mathrm{OCH}_{3}$

10c: $R=H$

11c: $R=H$

Each respective aldehyde $(0.15 \mathrm{mmol})$ and $9.0 \times 10^{-3} \mathrm{M}$ THF solution of $4 \mathrm{~b}(0.007 \mathrm{mmol}$;

$5 \mathrm{~mol} \%)$ were dissolved in $1.0 \mathrm{~mL}$ of THF. Allyltributyltin $(56 \mu \mathrm{L}, 0.18 \mathrm{mmol})$ was added to the stirring solution at RT. The reaction was stirred at $60^{\circ} \mathrm{C}$ for $24 \mathrm{~h}$. The solvent was removed in vacuo and the residual material was analyzed by ${ }^{1} \mathrm{H}$ NMR spectroscopy. 


\section{CHAPTER 6 - CONCLUSION AND FUTURE WORK}

A modular approach towards synthesis of novel asymmetric achiral and chiral pincer ligands of NNN, NNC and NNP types was developed. Fifteen novel pincer ligands have been synthesized following the method developed; showcasing the ease and the accessibility towards the presence of different functional groups. The investigation towards the complexation of these pincer ligands was performed with $\mathrm{Pd}$ and $\mathrm{Ni}$ metal centres. However, only Pd complexes were successfully synthesized from $42-98 \%$ yield and characterized by elemental analysis, and NMR spectroscopy. A catalytic study was performed using $9 \mathrm{~b}(5 \mathrm{~mol} \%)$ in allylation of benzaldehyde, $p$-nitrobenzaldehyde, and $p$ methoxybenzaldehyde. The preliminary results showed successful conversion of up to $99 \%$.

As part of the future work, both chiral and achiral pincer complexes can be screened for catalytic activity with the above described (allylation of aldehydes) and other types of reactions. Chiral derivatives of these ligands are of immense interest due to their ability to catalyze reactions with stereospecific products. 


\section{CHAPTER 7 - APPENDIX}

7.1 NMR SPECTRA

Figure A1. ${ }^{1} \mathrm{H}-\mathrm{NMR}$ Spectrum of 2 in $\mathrm{CDCl}_{3}$

Figure A2. ${ }^{13} \mathrm{C}-\mathrm{NMR}$ Spectrum of 2 in $\mathrm{CDCl}_{3}$

Figure A3. ${ }^{1} \mathrm{H}-\mathrm{NMR}$ Spectrum of $3 \mathrm{a}$ in $\mathrm{CDCl}_{3}$

Figure A4. ${ }^{13} \mathrm{C}-\mathrm{NMR}$ Spectrum of $\mathbf{3 a}$ in $\mathrm{CDCl}_{3}$

Figure A5. ${ }^{1} \mathrm{H}-\mathrm{NMR}$ Spectrum of $\mathbf{3 b}$ in $\mathrm{CDCl}_{3}$

Figure A6. ${ }^{13} \mathrm{C}-\mathrm{NMR}$ Spectrum of $\mathbf{3} \mathbf{b}$ in $\mathrm{CDCl}_{3}$

Figure A7. ${ }^{1} \mathrm{H}-\mathrm{NMR}$ Spectrum of $3 \mathrm{c}$ in $\mathrm{CDCl}_{3}$

Figure A8. ${ }^{13} \mathrm{C}-\mathrm{NMR}$ Spectrum of $3 \mathbf{c}$ in $\mathrm{CDCl}_{3}$

Figure A9. ${ }^{1} \mathrm{H}-\mathrm{NMR}$ Spectrum of $\mathbf{3 d}$ in $\mathrm{CDCl}_{3}$

Figure A10. ${ }^{13} \mathrm{C}-\mathrm{NMR}$ Spectrum of $\mathbf{3 d}$ in $\mathrm{CDCl}_{3}$

Figure A11. ${ }^{1} \mathrm{H}-\mathrm{NMR}$ Spectrum of $\mathbf{3 e}$ in $\mathrm{CDCl}_{3}$

Figure A12. ${ }^{13} \mathrm{C}-\mathrm{NMR}$ Spectrum of $\mathbf{3 e}$ in $\mathrm{CDCl}_{3}$

Figure A13. ${ }^{1} \mathrm{H}-\mathrm{NMR}$ Spectrum of $\mathbf{3} \mathbf{f}$ in $\mathrm{CDCl}_{3}$

Figure A14. ${ }^{13} \mathrm{C}-\mathrm{NMR}$ Spectrum of $\mathbf{3} \mathbf{f}$ in $\mathrm{CDCl}_{3}$

Figure A15. ${ }^{1} \mathrm{H}-\mathrm{NMR}$ Spectrum of $\mathbf{3 g}$ in $\mathrm{CDCl}_{3}$

Figure A16. ${ }^{13} \mathrm{C}-\mathrm{NMR}$ Spectrum of $\mathbf{3 g}$ in $\mathrm{CDCl}_{3}$

Figure A17. ${ }^{1} \mathrm{H}-\mathrm{NMR}$ Spectrum of $\mathbf{3 h}$ in $\mathrm{CDCl}_{3}$

Figure A18. ${ }^{13} \mathrm{C}-\mathrm{NMR}$ Spectrum of $\mathbf{3 h}$ in $\mathrm{CDCl}_{3}$

Figure A19. ${ }^{1} \mathrm{H}-\mathrm{NMR}$ Spectrum of $\mathbf{3 i}$ in $\mathrm{CDCl}_{3}$

Figure A20. ${ }^{13} \mathrm{C}-\mathrm{NMR}$ Spectrum of $\mathbf{3 i}$ in $\mathrm{CDCl}_{3}$

Figure A21. ${ }^{1} \mathrm{H}-\mathrm{NMR}$ Spectrum of $\mathbf{3 j}$ in $\mathrm{CDCl}_{3}$ 
Figure A22. ${ }^{13} \mathrm{C}-\mathrm{NMR}$ Spectrum of $\mathbf{3} \mathbf{j}$ in $\mathrm{CDCl}_{3}$

Figure A23. ${ }^{1} \mathrm{H}-\mathrm{NMR}$ Spectrum of $\mathbf{3 k}$ in $\mathrm{CDCl}_{3}$

Figure A24. ${ }^{13} \mathrm{C}-\mathrm{NMR}$ Spectrum of $\mathbf{3 k}$ in $\mathrm{CDCl}_{3}$

Figure A25. ${ }^{1} \mathrm{H}-\mathrm{NMR}$ Spectrum of $3 \mathbf{l}$ in $\mathrm{CDCl}_{3}$

Figure A26. ${ }^{13} \mathrm{C}-\mathrm{NMR}$ Spectrum of $3 \mathrm{I}$ in $\mathrm{CDCl}_{3}$

Figure A27. ${ }^{1} \mathrm{H}-\mathrm{NMR}$ Spectrum of $3 \mathrm{~m} \cdot$ oxide in $\mathrm{CDCl}_{3}$

Figure A28. ${ }^{13} \mathrm{C}-\mathrm{NMR}$ Spectrum of $\mathbf{3 m} \cdot \mathbf{o x i d e}$ in $\mathrm{CDCl}_{3}$

Figure A29. ${ }^{31} \mathrm{P}$-NMR Spectrum of $3 \mathrm{~m} \bullet$ oxide in $\mathrm{CDCl}_{3}$

Figure A30. ${ }^{1} \mathrm{H}-\mathrm{NMR}$ Spectrum of $\mathbf{3 n}$ in $\mathrm{CDCl}_{3}$

Figure A31. ${ }^{13} \mathrm{C}-\mathrm{NMR}$ Spectrum of $\mathbf{3 n}$ in $\mathrm{CDCl}_{3}$

Figure A32. ${ }^{1} \mathrm{H}-\mathrm{NMR}$ Spectrum of 4 in $\mathrm{CDCl}_{3}$

Figure A33. ${ }^{13} \mathrm{C}-\mathrm{NMR}$ Spectrum of $\mathbf{4}$ in $\mathrm{CDCl}_{3}$

Figure A34. ${ }^{1} \mathrm{H}-\mathrm{NMR}$ Spectrum of 6 in $\mathrm{CDCl}_{3}$

Figure A35. ${ }^{13} \mathrm{C}-\mathrm{NMR}$ Spectrum of 6 in $\mathrm{CDCl}_{3}$

Figure A36. ${ }^{1} \mathrm{H}-\mathrm{NMR}$ Spectrum of 7 in $\mathrm{CDCl}_{3}$

Figure A37. ${ }^{1} \mathrm{H}-\mathrm{NMR}$ Spectrum of $9 \mathrm{a}$ in $\mathrm{CDCl}_{3}$

Figure A38. ${ }^{13} \mathrm{C}-\mathrm{NMR}$ Spectrum of $9 \mathrm{a}$ in $\mathrm{CDCl}_{3}$

Figure A39. ${ }^{1} \mathrm{H}-\mathrm{NMR}$ Spectrum of $\mathbf{9 b}$ in $\mathrm{CDCl}_{3}$

Figure A40. ${ }^{13} \mathrm{C}-\mathrm{NMR}$ Spectrum of $\mathbf{9 b}$ in $\mathrm{CDCl}_{3}$

Figure A41. ${ }^{1} \mathrm{H}-\mathrm{NMR}$ Spectrum of $9 \mathrm{c}$ in $\mathrm{CDCl}_{3}$

Figure A42. ${ }^{13} \mathrm{C}-\mathrm{NMR}$ Spectrum of $9 \mathrm{c}$ in $\mathrm{CDCl}_{3}$

Figure A43. ${ }^{1} \mathrm{H}-\mathrm{NMR}$ Spectrum of $\mathbf{9 d}$ in $\mathrm{CDCl}_{3}$

Figure A44. ${ }^{13} \mathrm{C}-\mathrm{NMR}$ Spectrum of $9 \mathrm{~d}$ in $\mathrm{CDCl}_{3}$ 
Figure A45. ${ }^{1} \mathrm{H}-\mathrm{NMR}$ Spectrum of $9 \mathrm{e}$ in $\mathrm{CDCl}_{3}$

Figure A46. ${ }^{13} \mathrm{C}-\mathrm{NMR}$ Spectrum of $9 \mathrm{e}$ in $\mathrm{CDCl}_{3}$

Figure A47. ${ }^{1} \mathrm{H}-\mathrm{NMR}$ Spectrum of $\mathbf{9 g}$ in $\mathrm{CDCl}_{3}$

Figure A48. ${ }^{13} \mathrm{C}-\mathrm{NMR}$ Spectrum of $\mathbf{9 g}$ in $\mathrm{CDCl}_{3}$

Figure A49. ${ }^{1} \mathrm{H}-\mathrm{NMR}$ Spectrum of $9 \mathrm{~h}$ in $\mathrm{CDCl}_{3}$

Figure A50. ${ }^{13} \mathrm{C}-\mathrm{NMR}$ Spectrum of $\mathbf{9 h}$ in $\mathrm{CDCl}_{3}$

Figure A51. ${ }^{1} \mathrm{H}-\mathrm{NMR}$ Spectrum of $\mathbf{9 i}$ in $\mathrm{CDCl}_{3}$

Figure A52. ${ }^{13} \mathrm{C}-\mathrm{NMR}$ Spectrum of $9 \mathrm{i}$ in $\mathrm{CDCl}_{3}$

Figure A53. ${ }^{1} \mathrm{H}-\mathrm{NMR}$ Spectrum of $9 \mathrm{j}$ in $\mathrm{CDCl}_{3}$

Figure A54. ${ }^{13} \mathrm{C}-\mathrm{NMR}$ Spectrum of $9 \mathrm{j}$ in $\mathrm{CDCl}_{3}$

Figure A55. ${ }^{1} \mathrm{H}-\mathrm{NMR}$ Spectrum of $\mathbf{9 k}$ in $\mathrm{CDCl}_{3}$

Figure A56. ${ }^{13} \mathrm{C}-\mathrm{NMR}$ Spectrum of $\mathbf{9 k}$ in $\mathrm{CDCl}_{3}$

Figure A57. ${ }^{1} \mathrm{H}-\mathrm{NMR}$ Spectrum of $9 \mathrm{I}$ in $\mathrm{CDCl}_{3}$

Figure A58. ${ }^{13} \mathrm{C}-\mathrm{NMR}$ Spectrum of $9 \mathrm{I}$ in $\mathrm{CDCl}_{3}$

Figure A59. ${ }^{1} \mathrm{H}-\mathrm{NMR}$ Spectrum of $9 \mathrm{~m}$ in $\mathrm{CDCl}_{3}$

Figure A60. ${ }^{13} \mathrm{C}-\mathrm{NMR}$ Spectrum of $9 \mathrm{~m}$ in $\mathrm{CDCl}_{3}$

Figure A61. ${ }^{31} \mathrm{P}-\mathrm{NMR}$ Spectrum of $9 \mathrm{~m}$ in $\mathrm{CDCl}_{3}$

Figure A62. ${ }^{1} \mathrm{H}-\mathrm{NMR}$ Spectra of the 11a-c conversion after $24 \mathrm{~h}$ in $\mathrm{CDCl}_{3}$ 


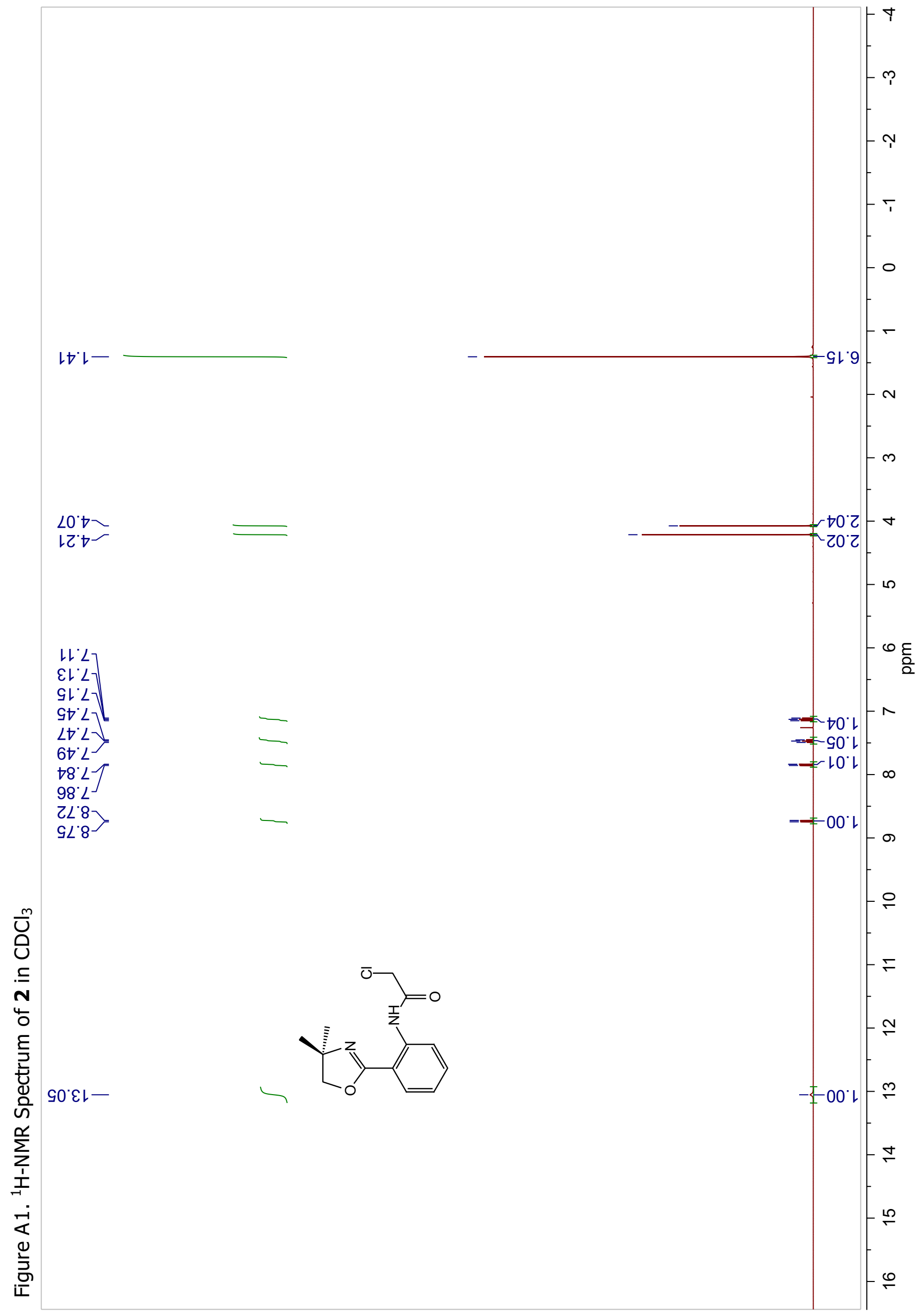



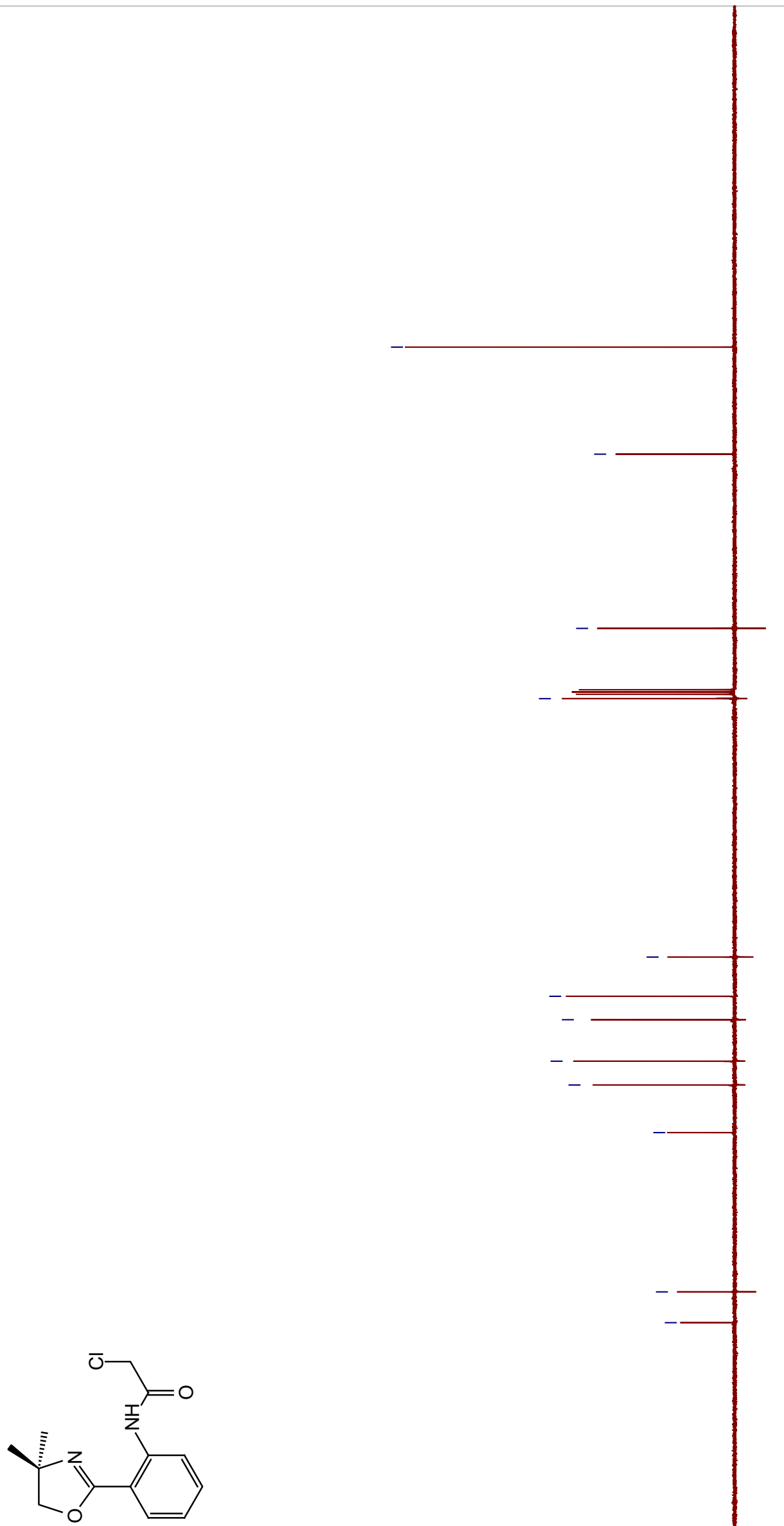


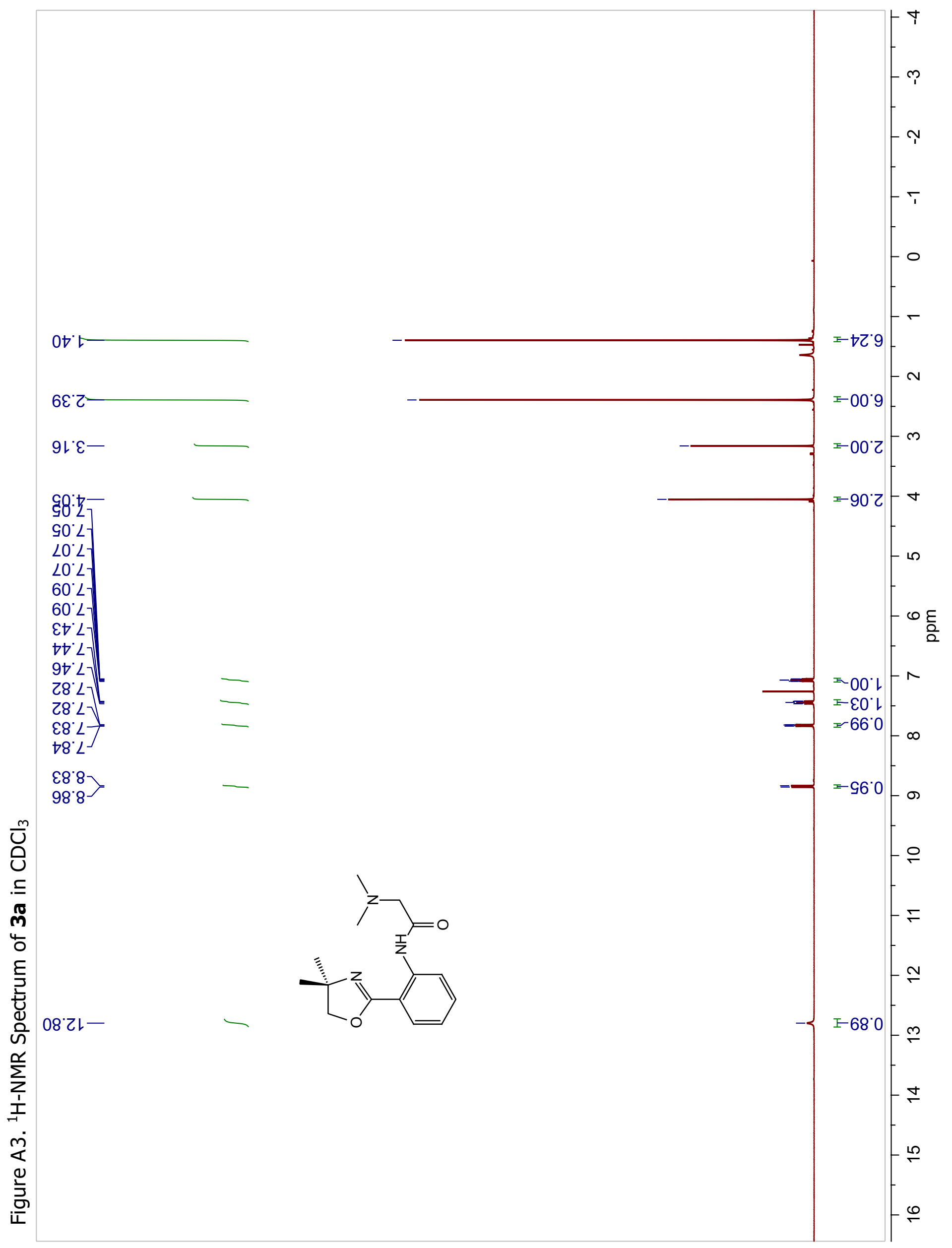




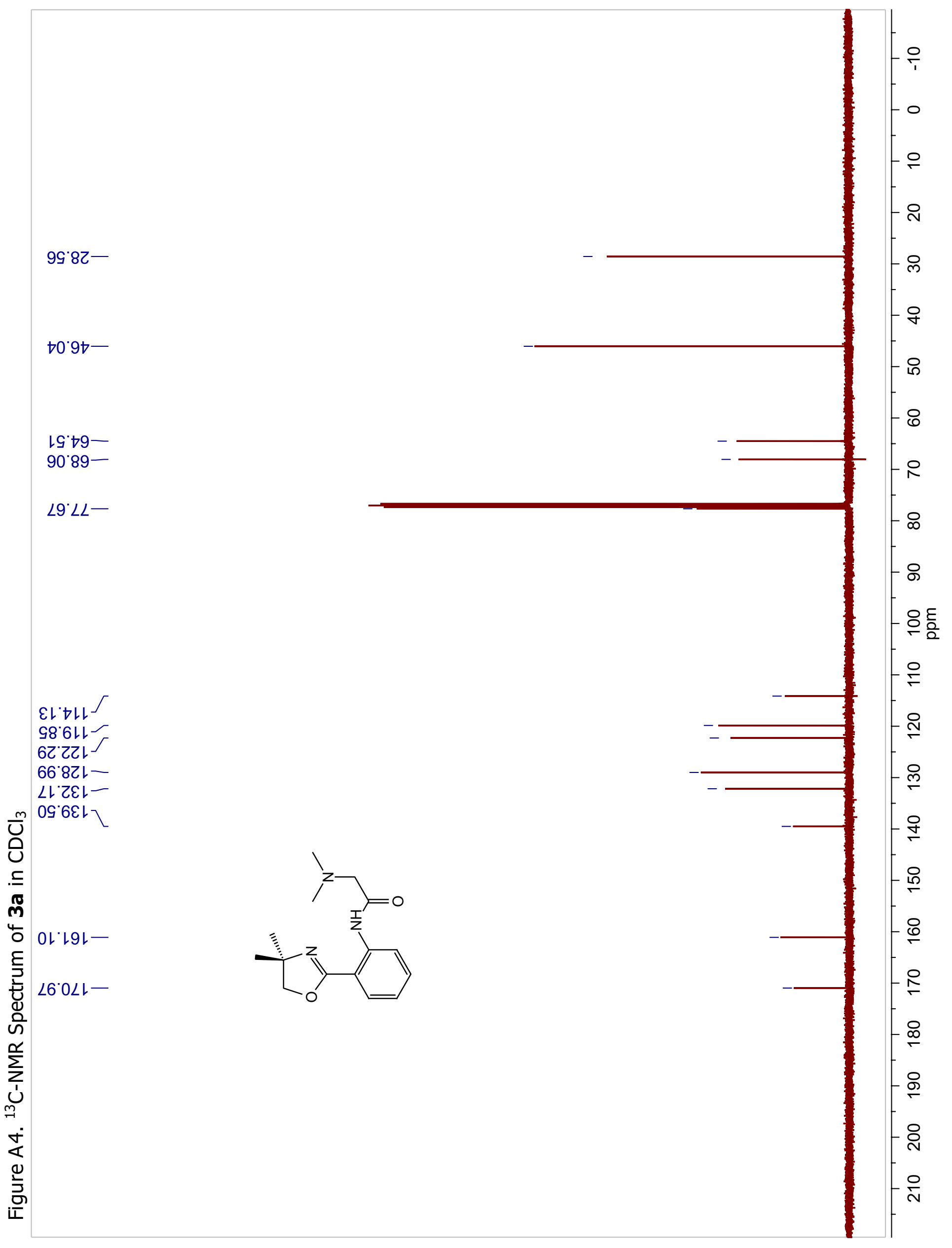




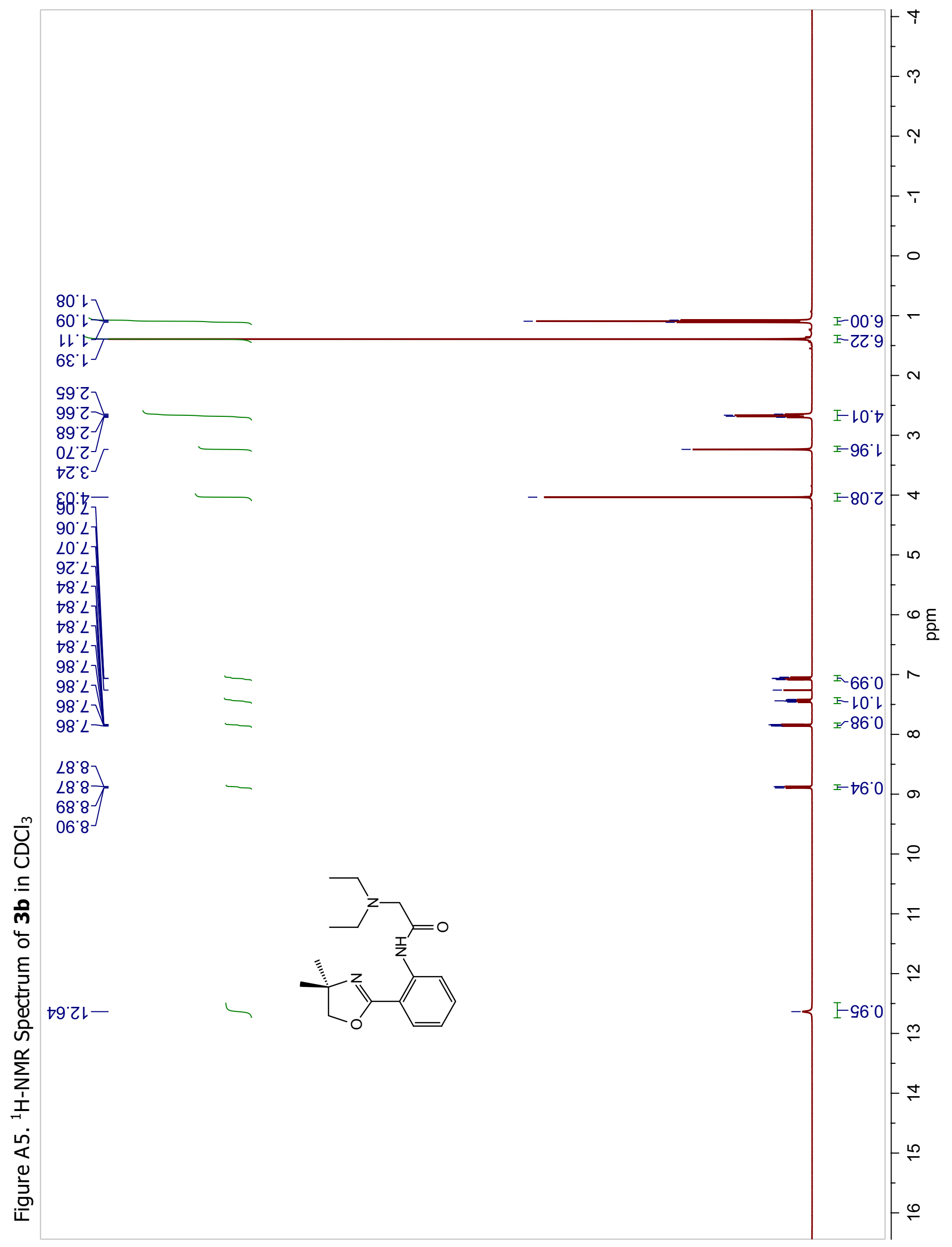




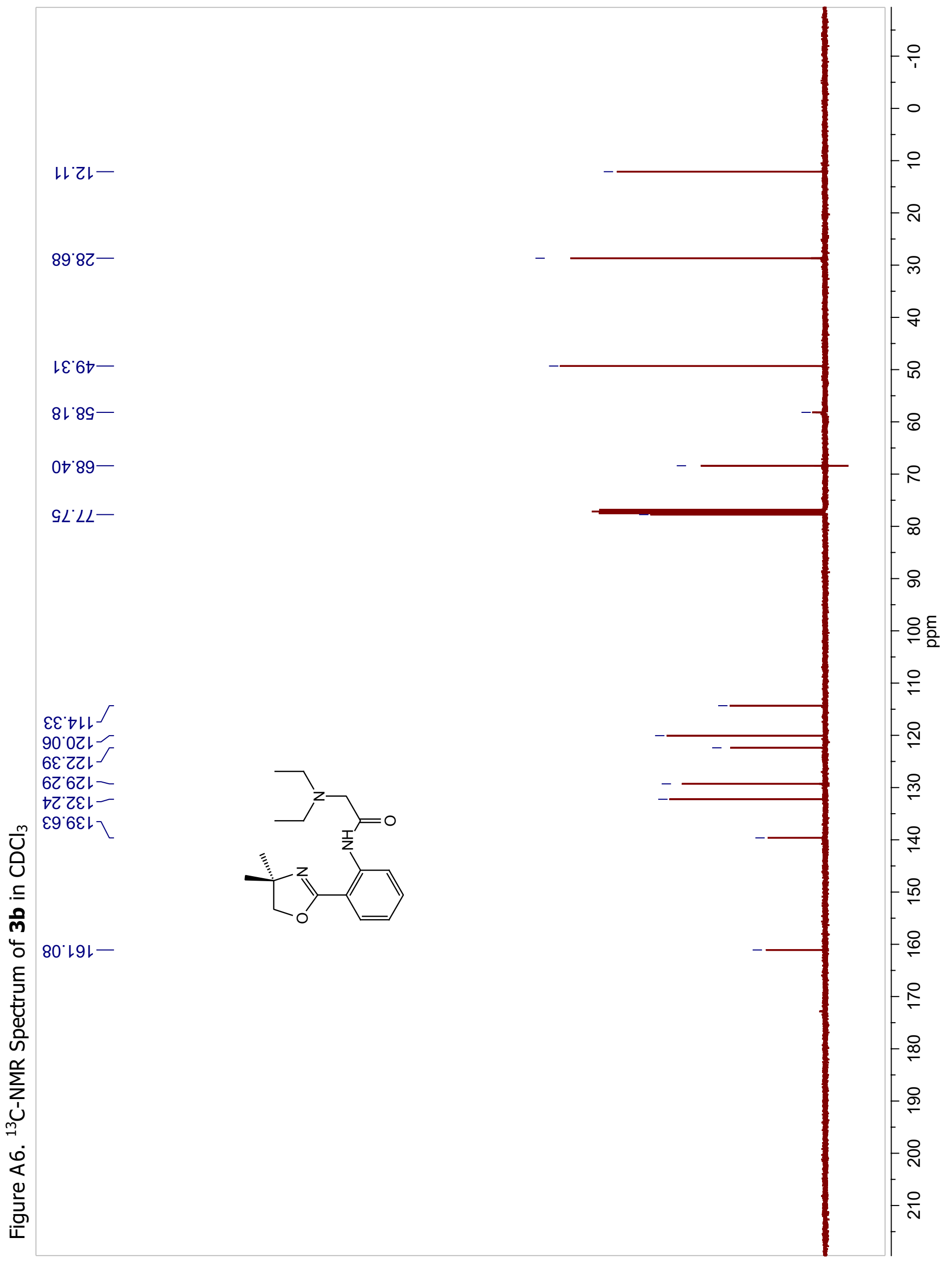




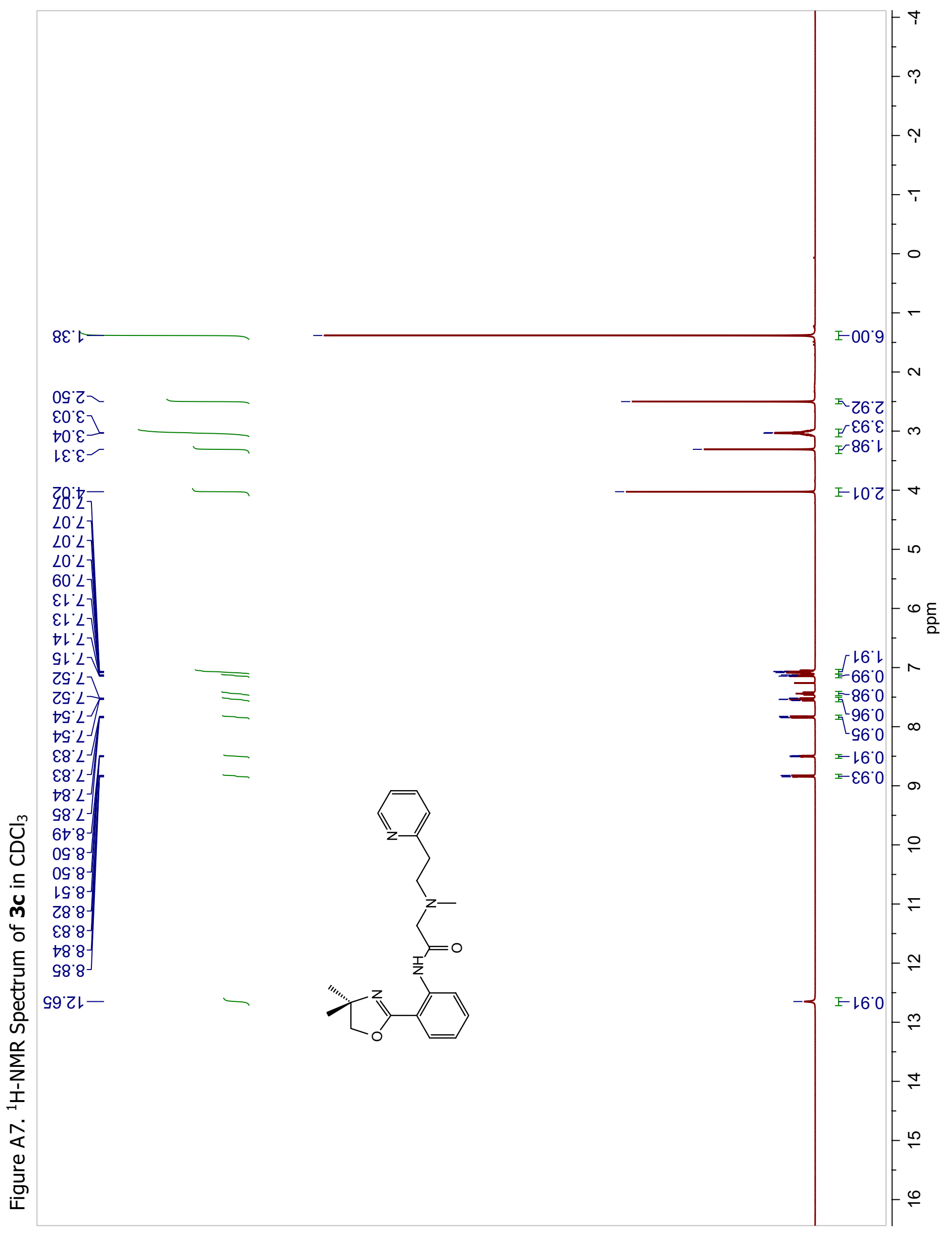




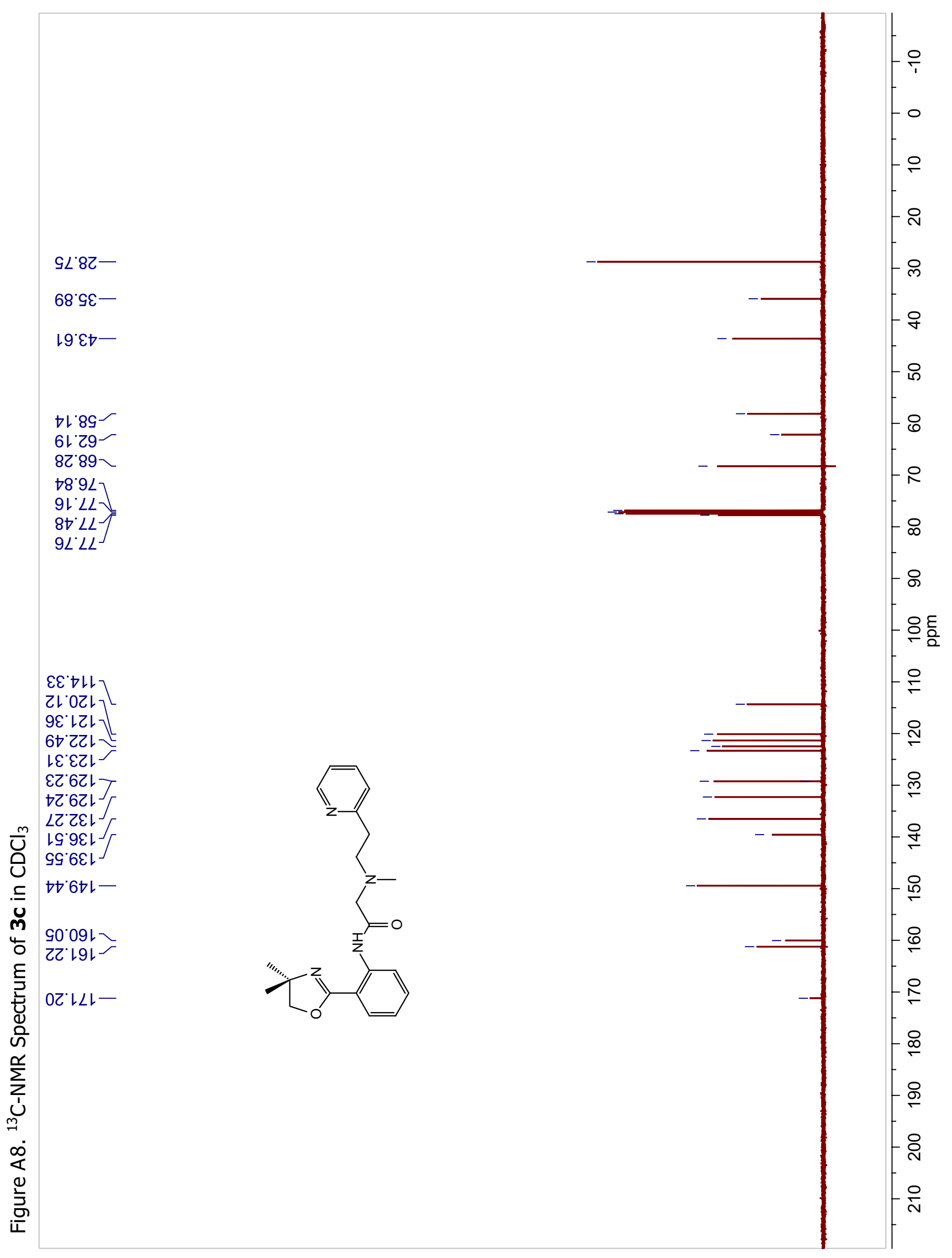




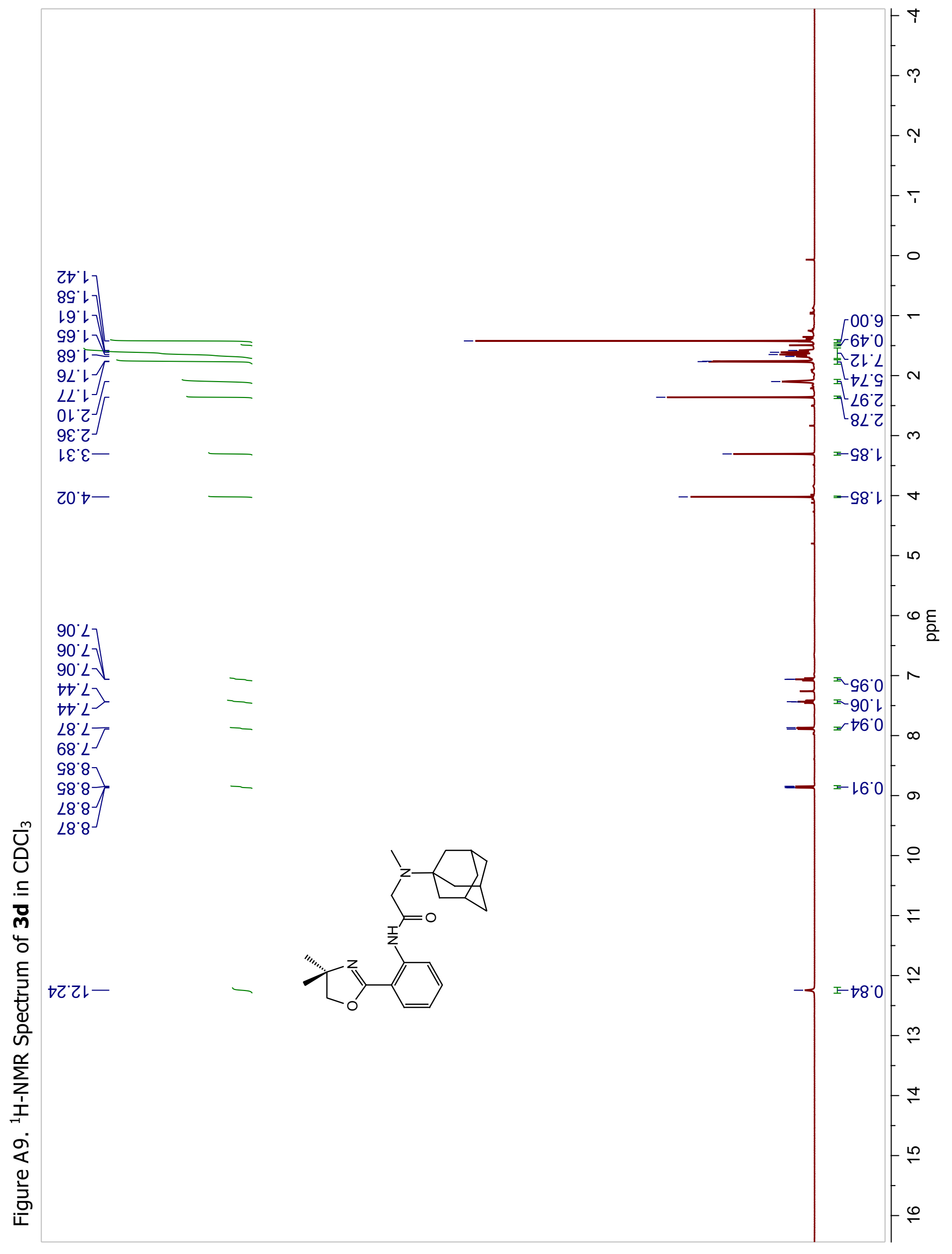


$0<8 乙$

$79^{\circ} 62=$

$\varepsilon 乙 ' 9 \varepsilon$

†8 $9 \varepsilon$

$69^{\circ} 8 \varepsilon^{-}$

$\nabla \varepsilon^{\circ} \nabla G-$

$10.99-$

99.89-

98.9L

$9 L^{\circ} L L$

$8 D^{\circ} L L$

$G L L L$

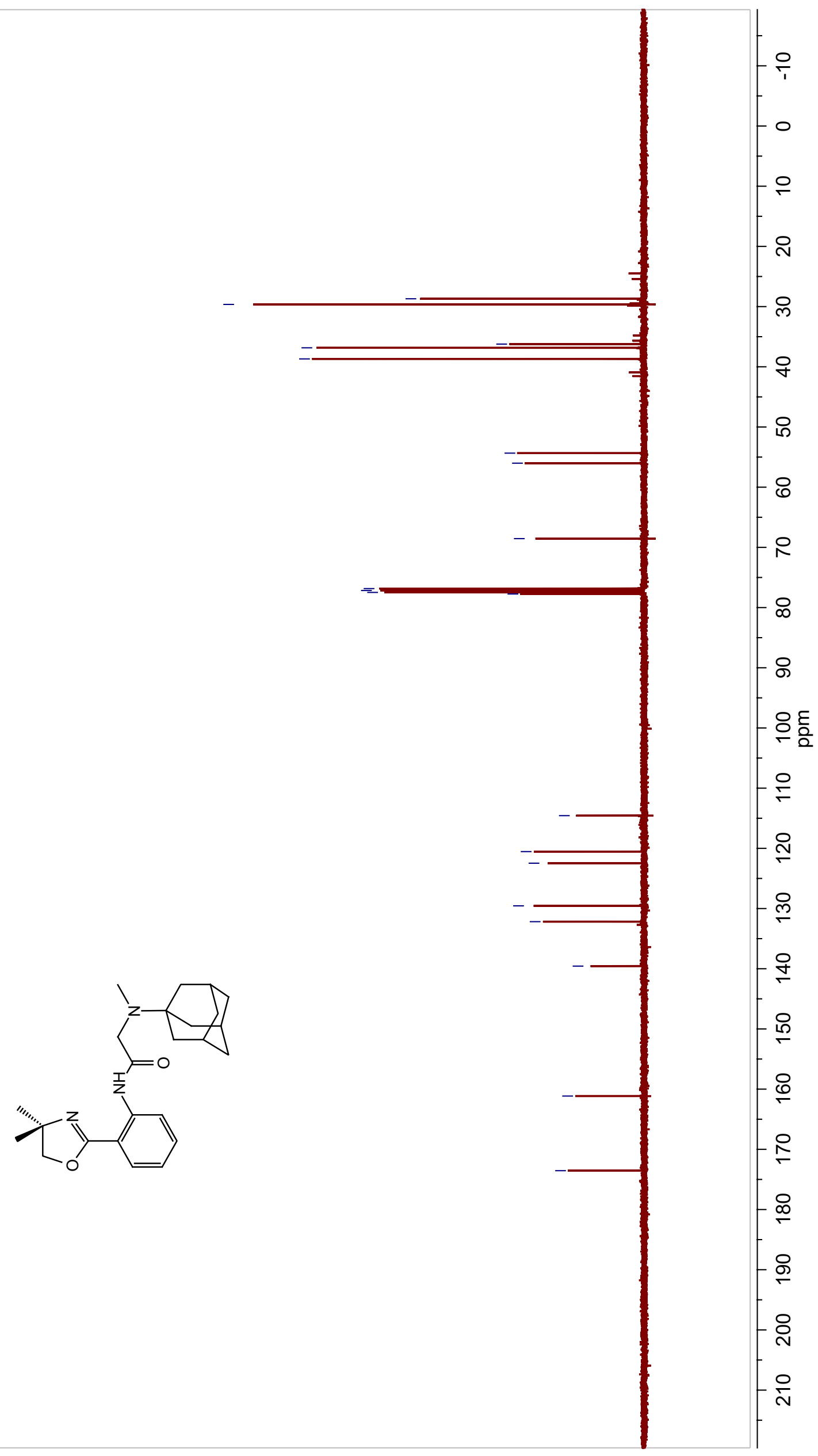




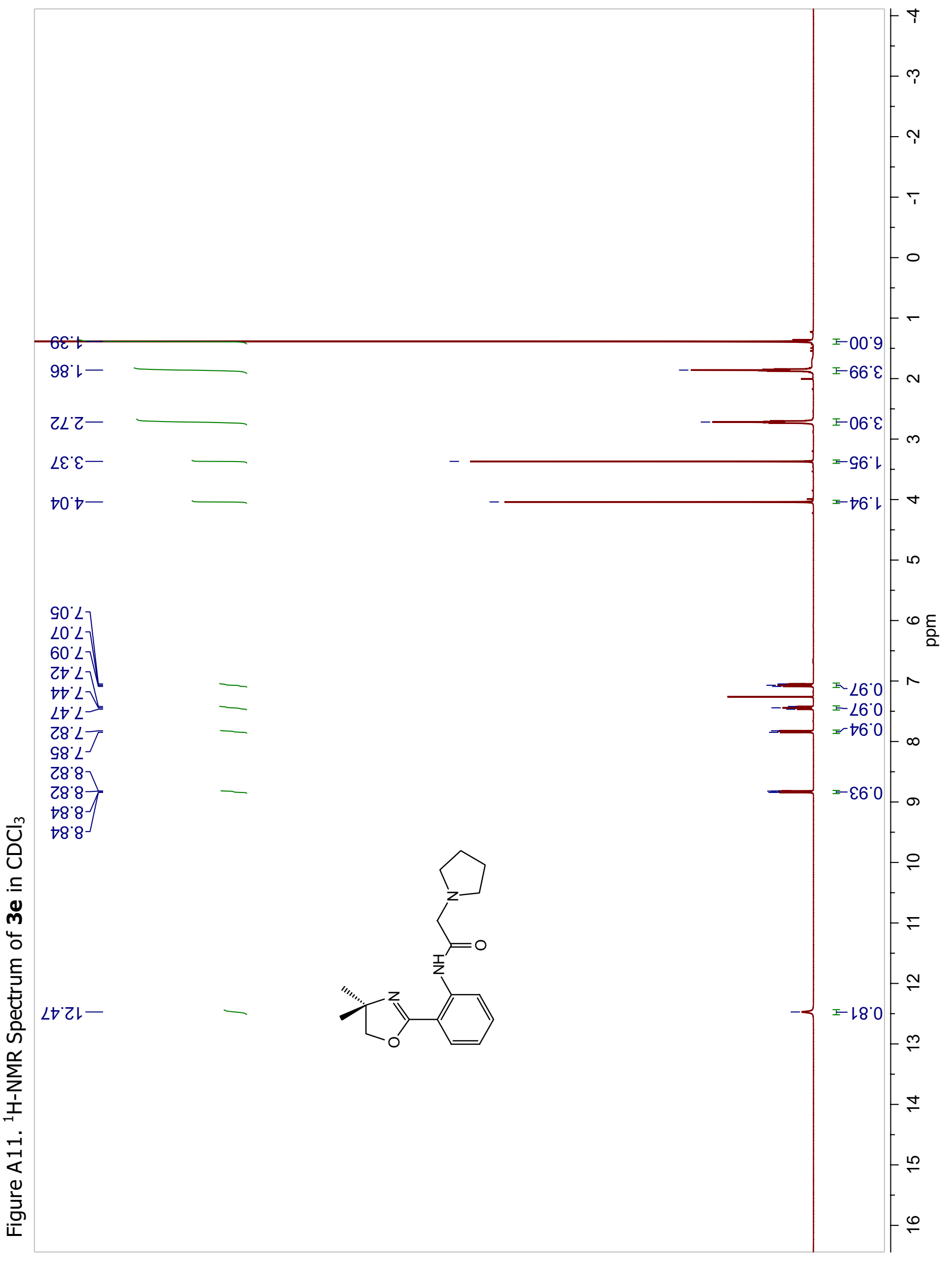




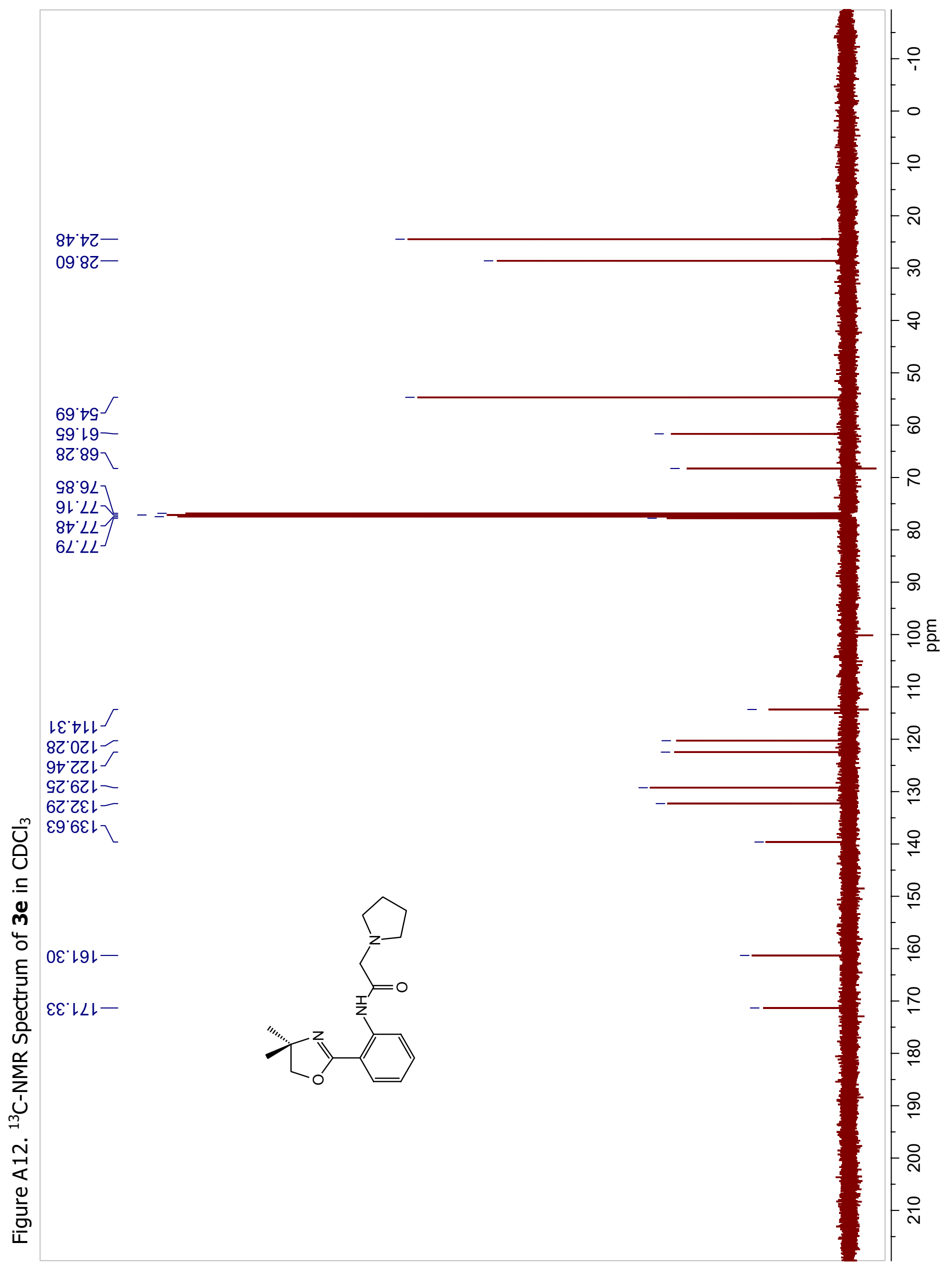




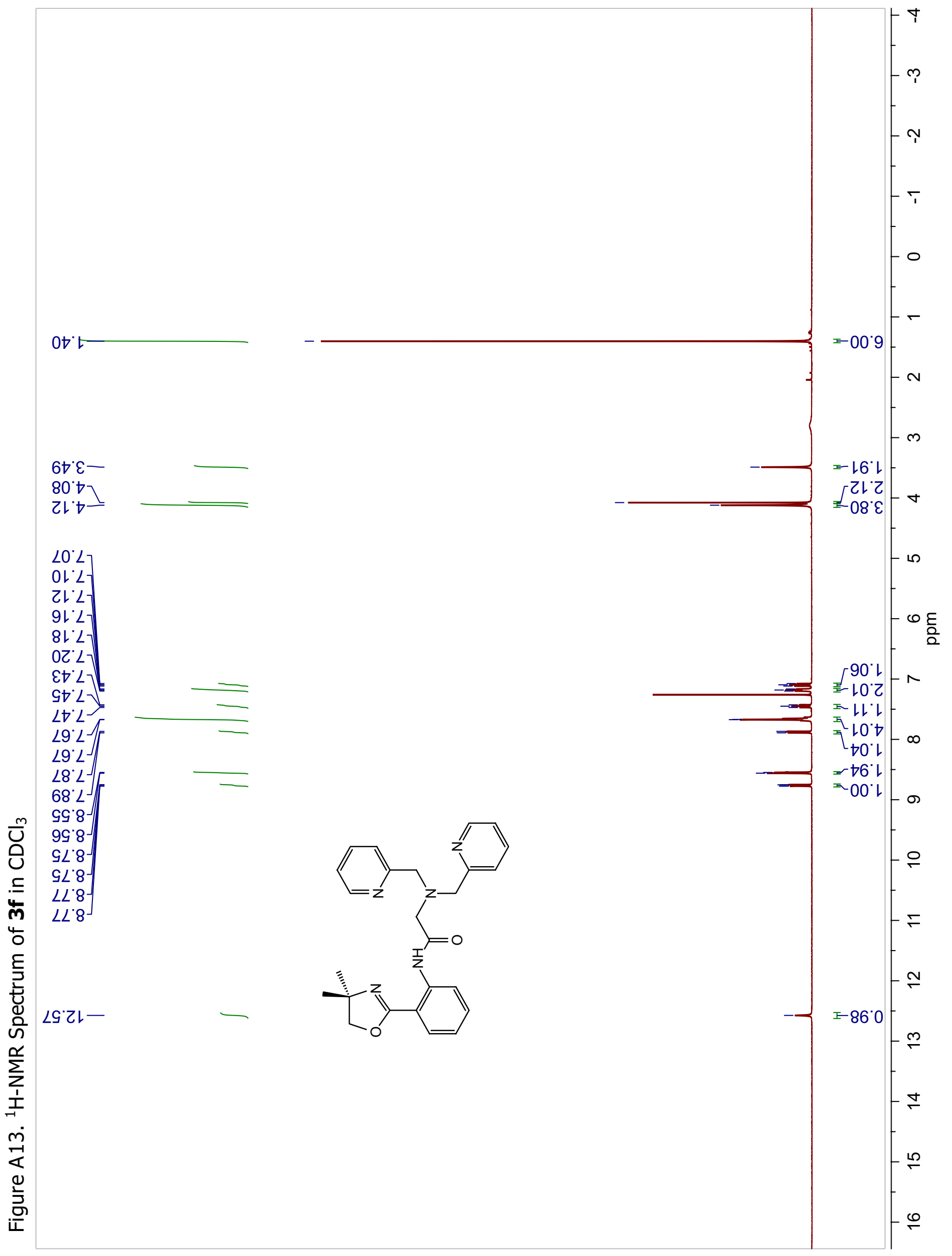




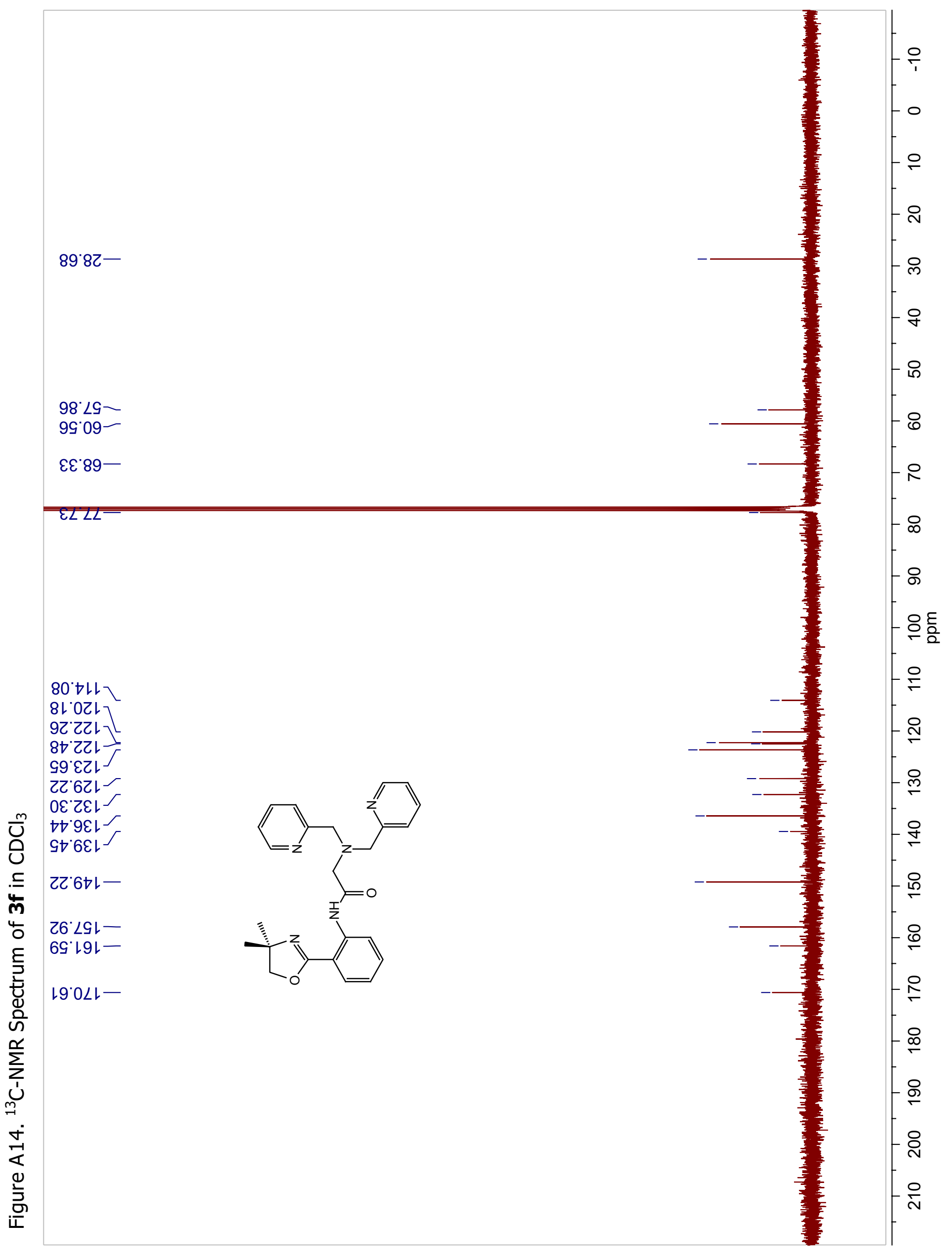




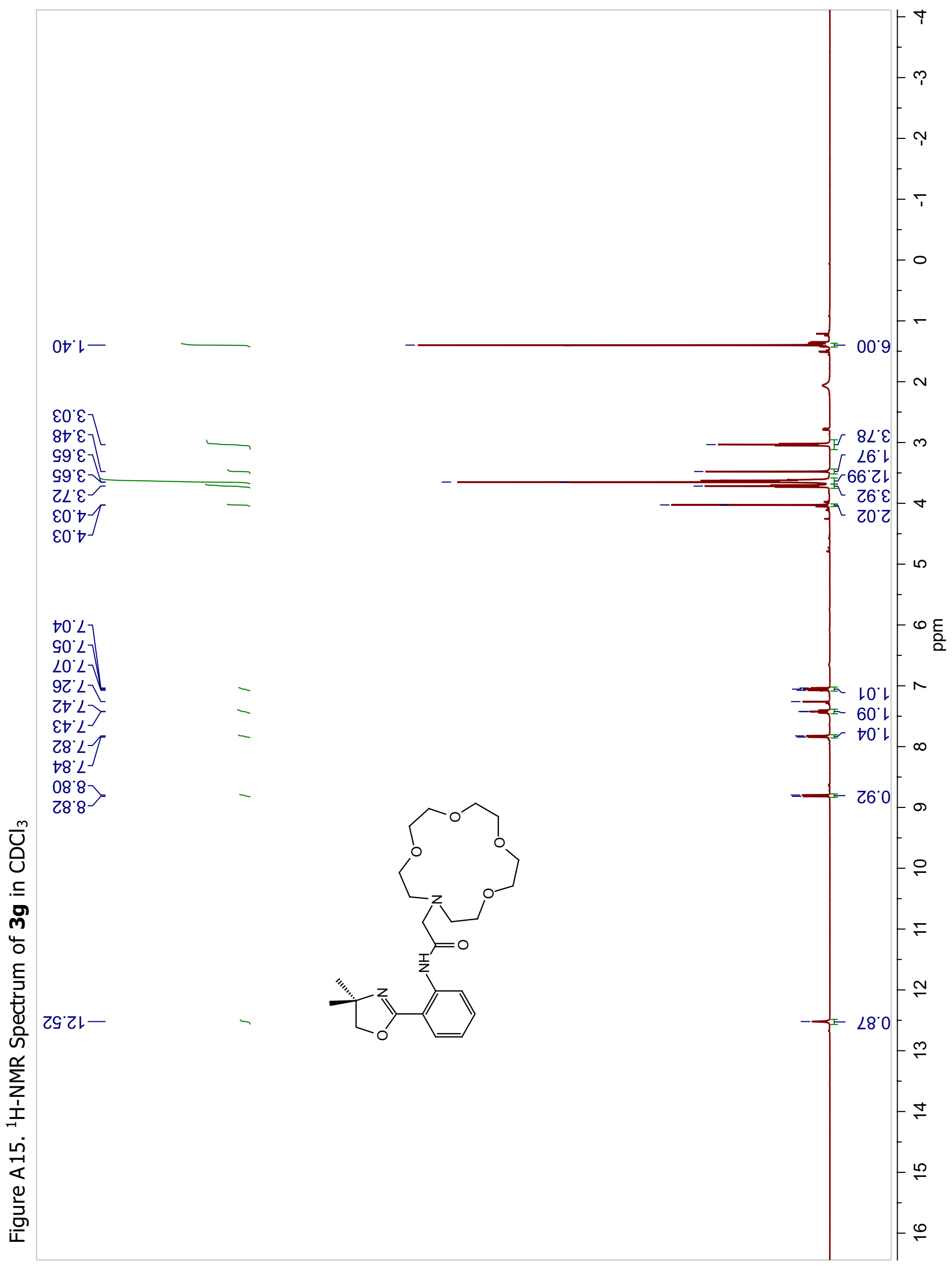




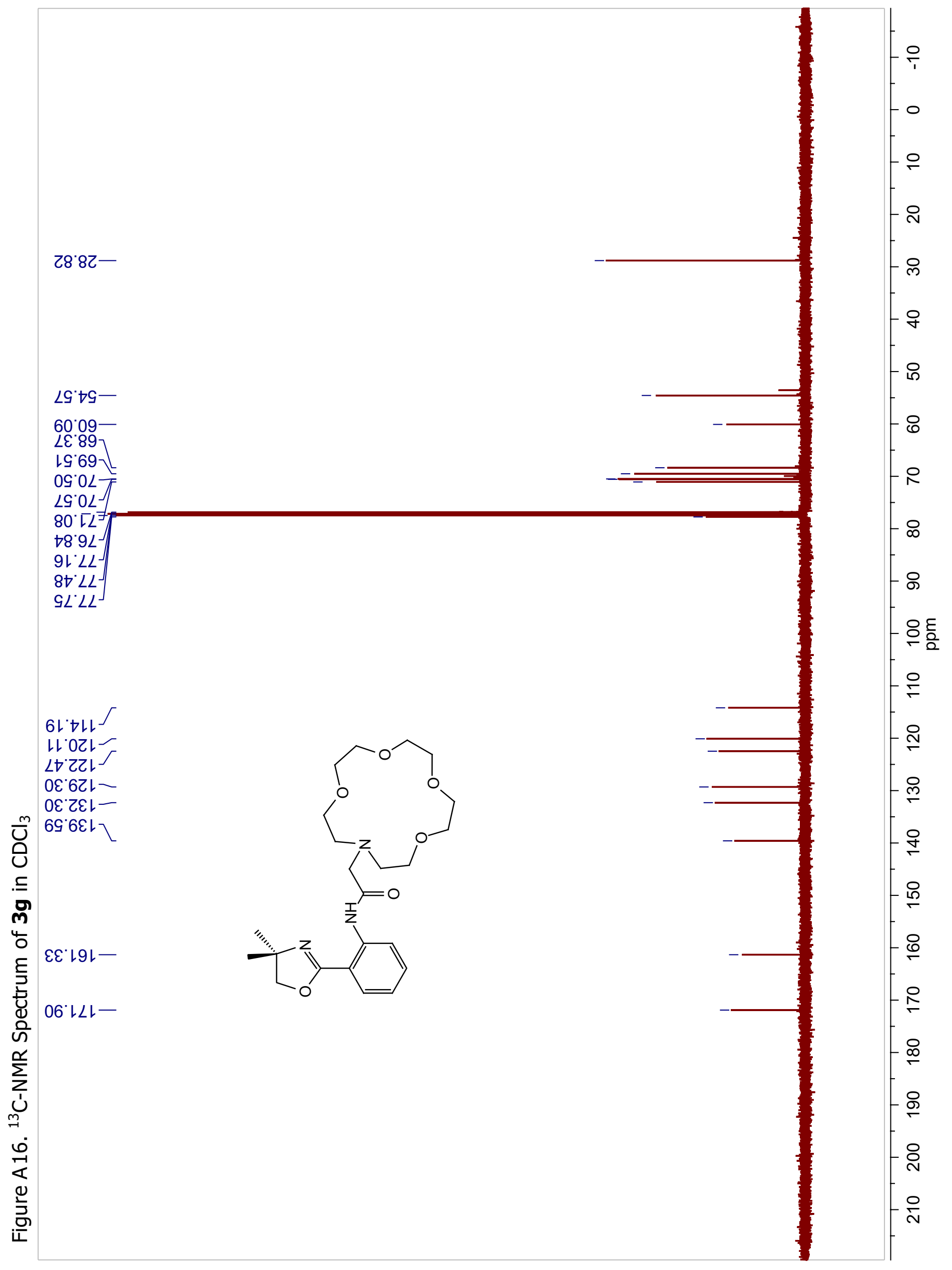




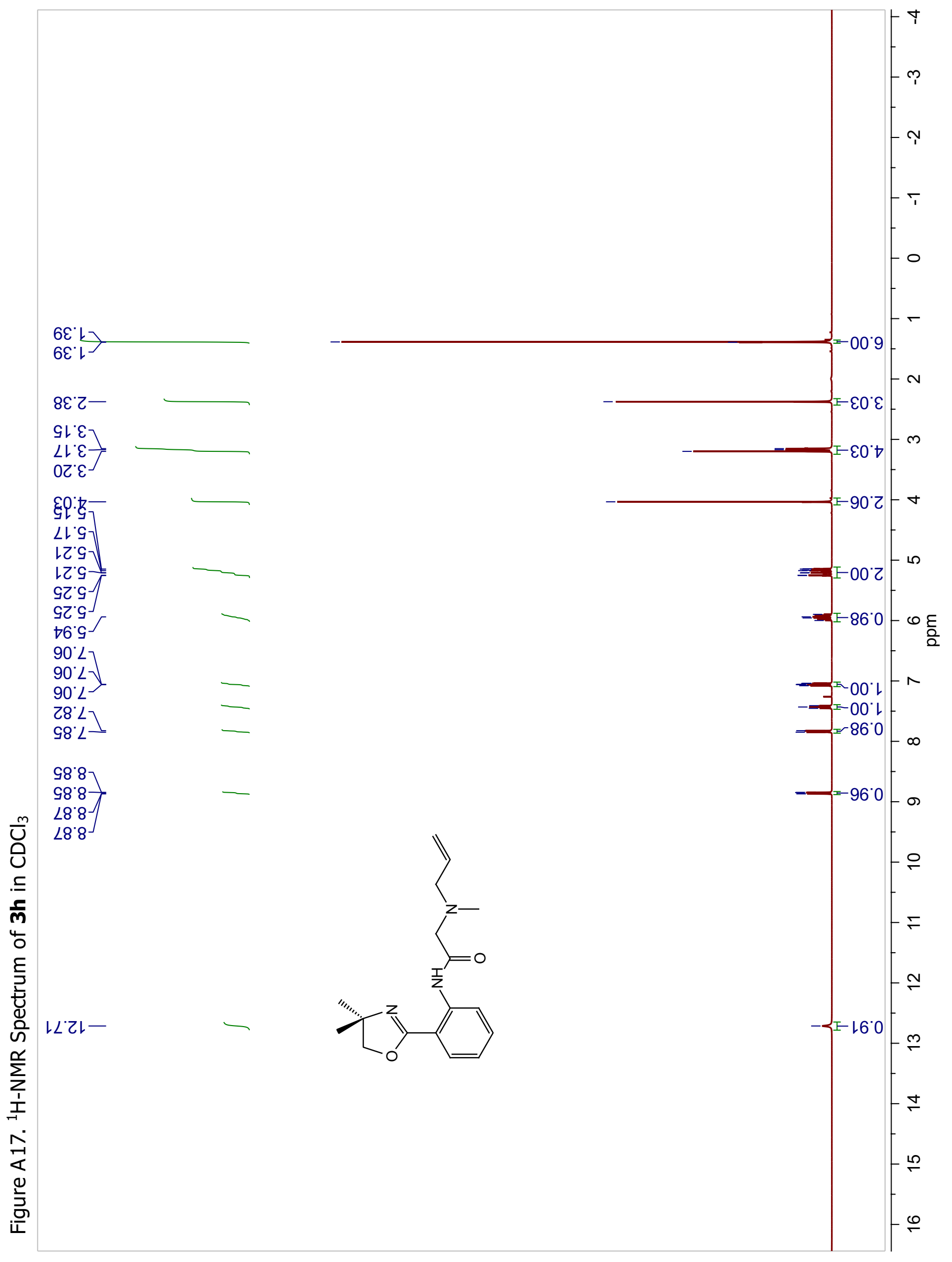




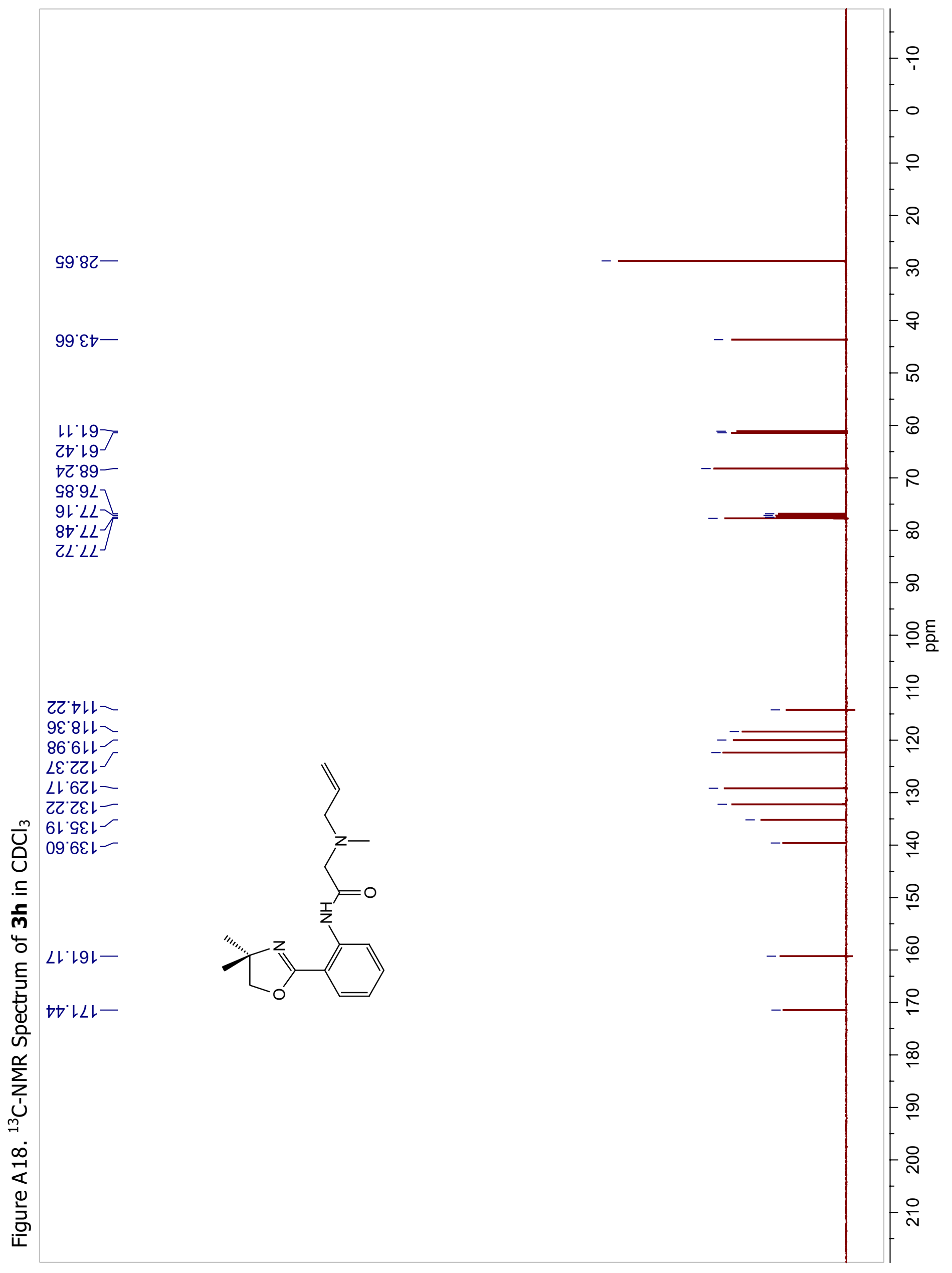




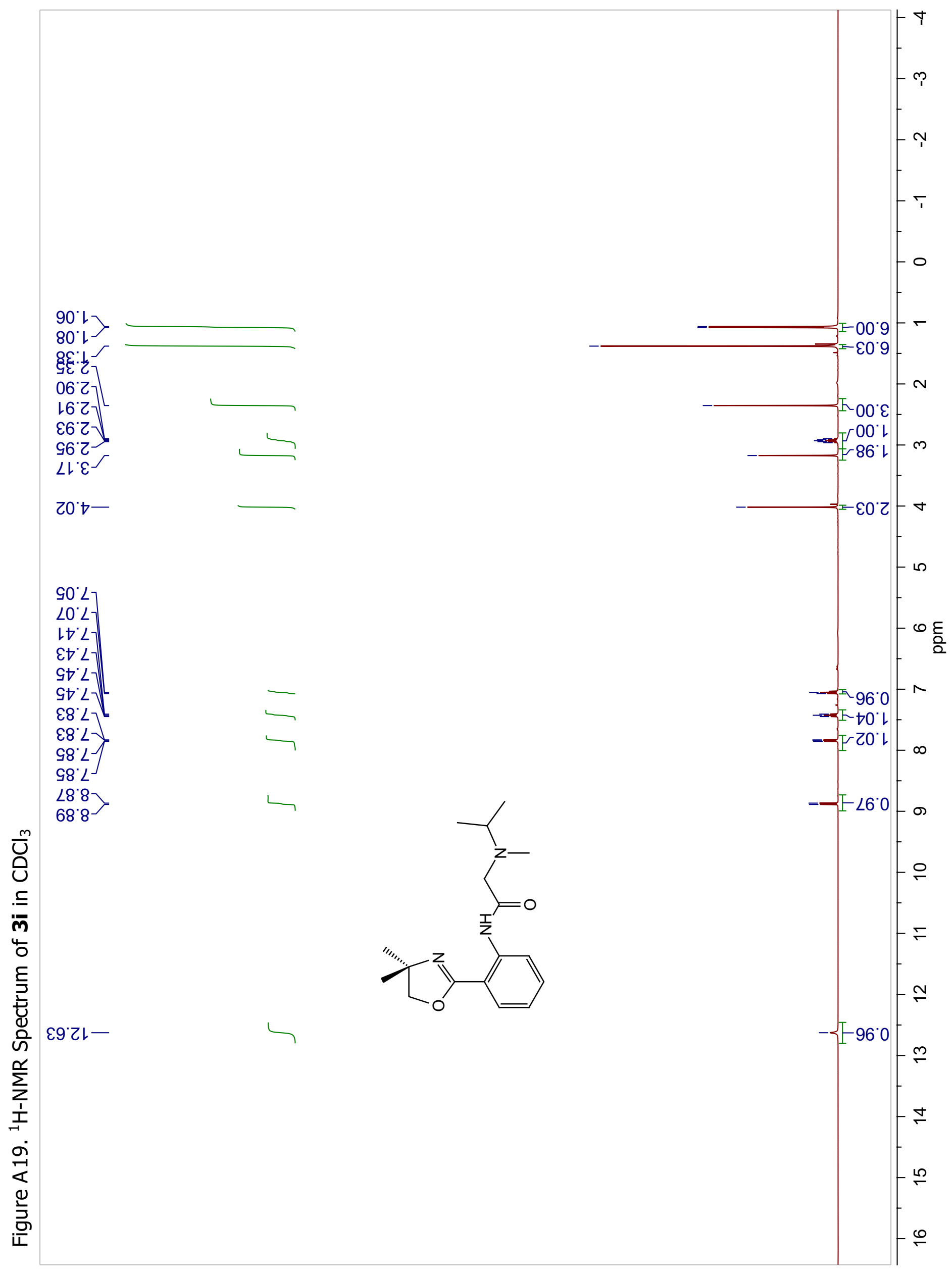


SL8L-

२९ $82-$

Gレ'0t-

$82^{\circ}+9-$

$\angle 0^{\circ} \angle 9-$

ع乙'89-

$\angle L ' 9 L$

$60^{\circ} \angle L$

$10^{\circ} L L-1$
$6 S^{\circ} \angle L$

8Z゙เレ

66.6⿰丿⿱丄𠃍卜

8Z ZZL

6เ6ZL -

OL'ZعL-

$\frac{m}{\cup}$ LG $6 \varepsilon L$
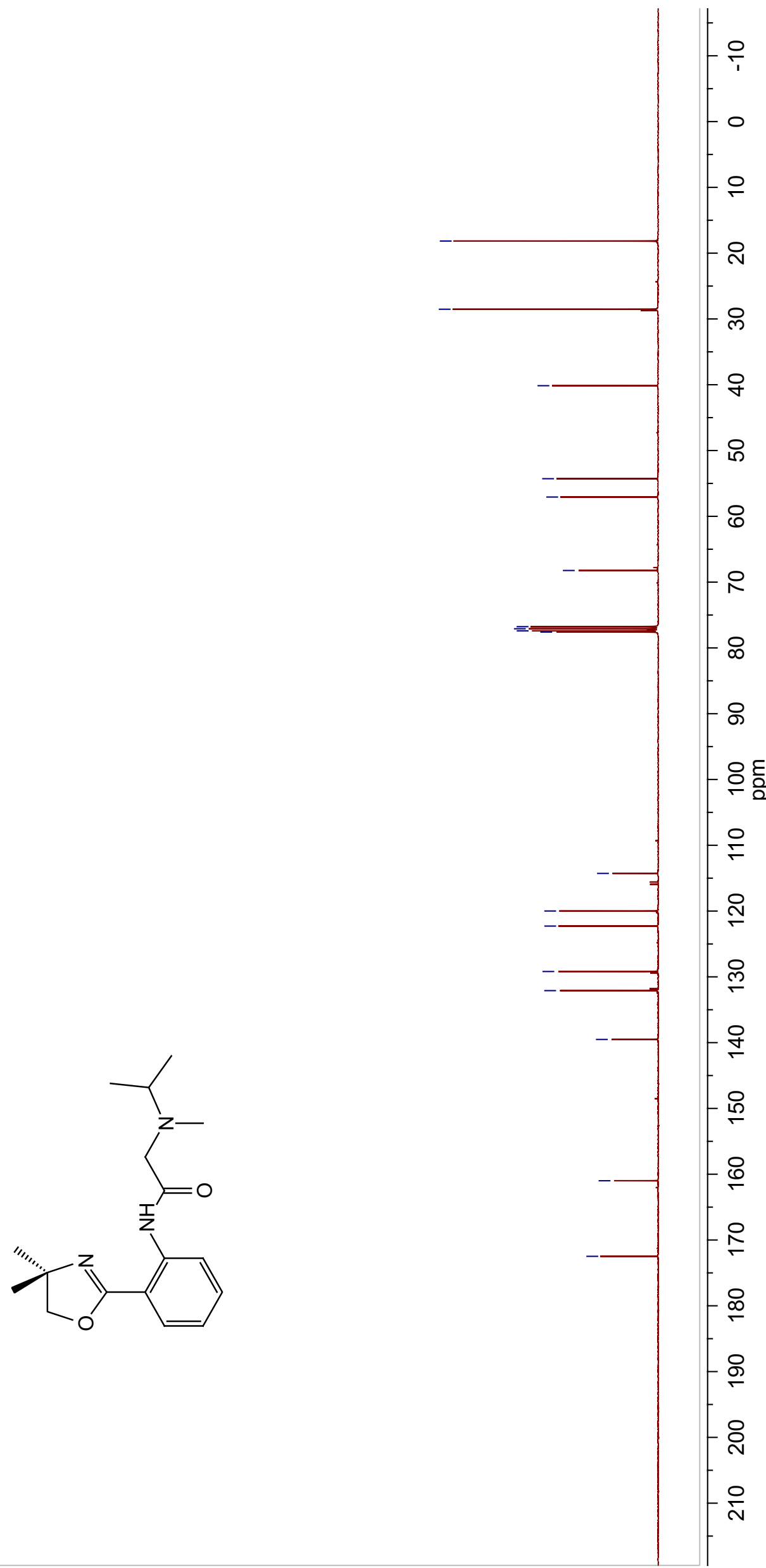


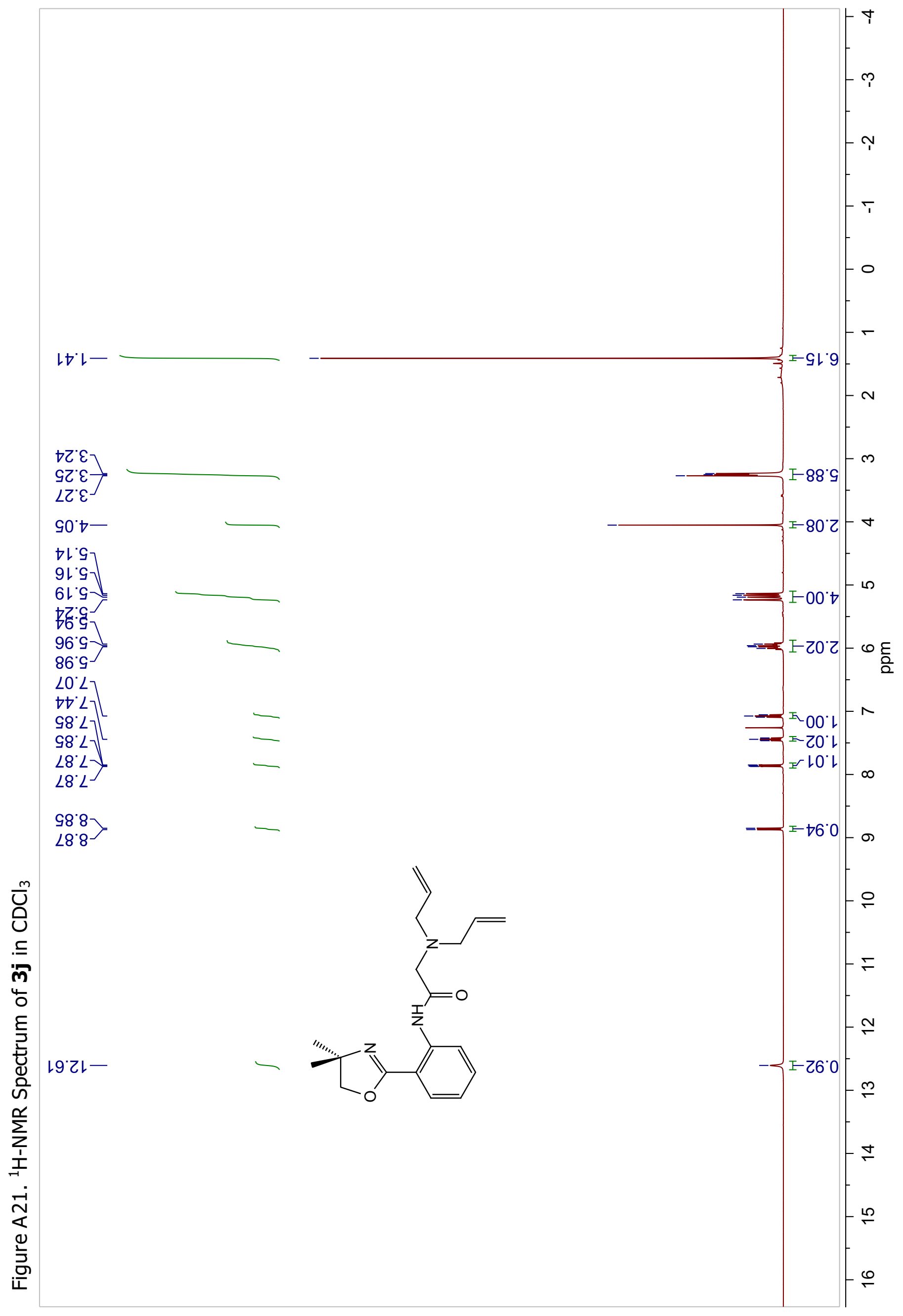



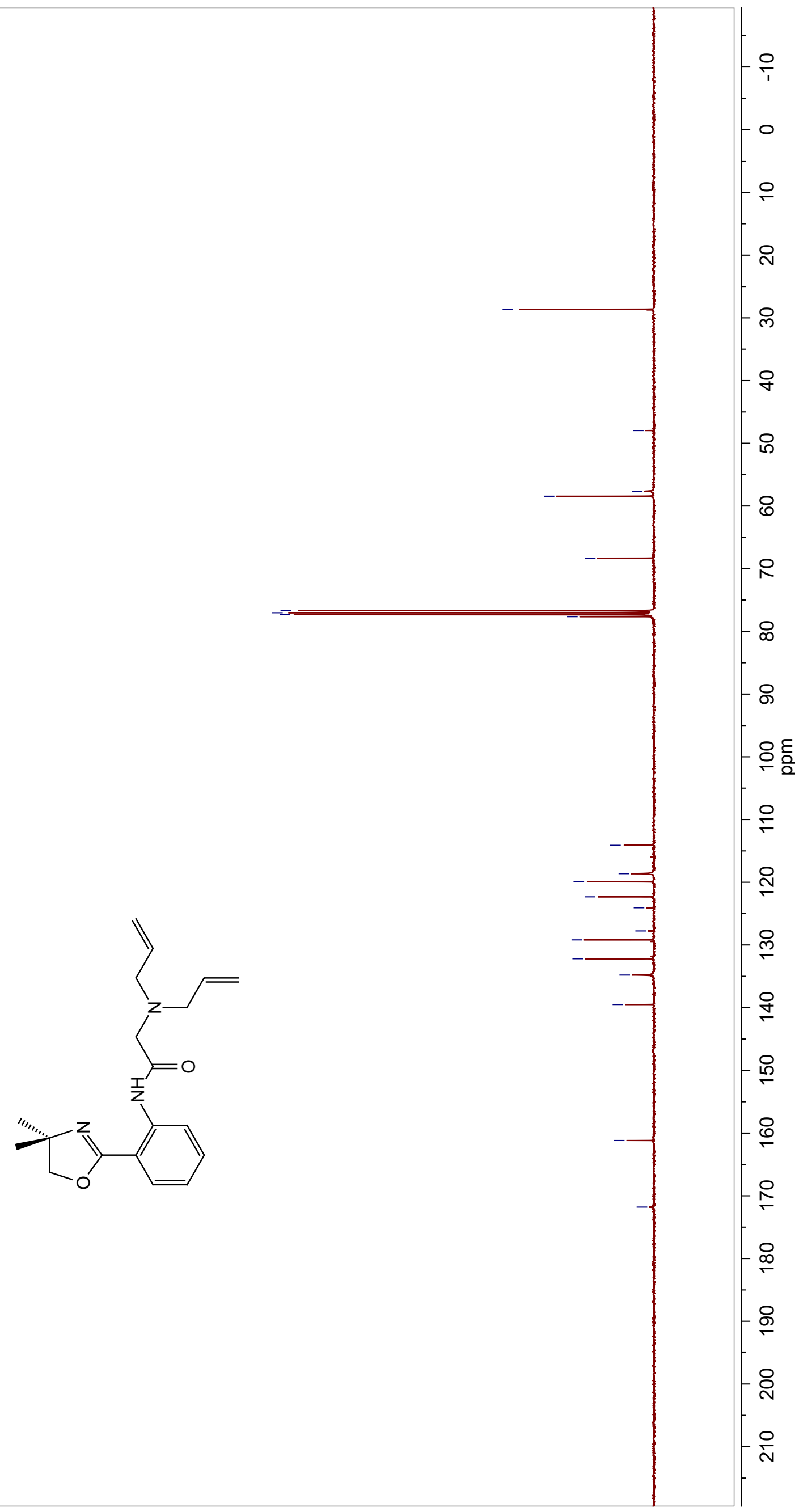

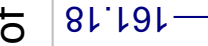

है

08ㄴレー

$\sum_{j}^{\alpha}$

ัำ

0

흔 


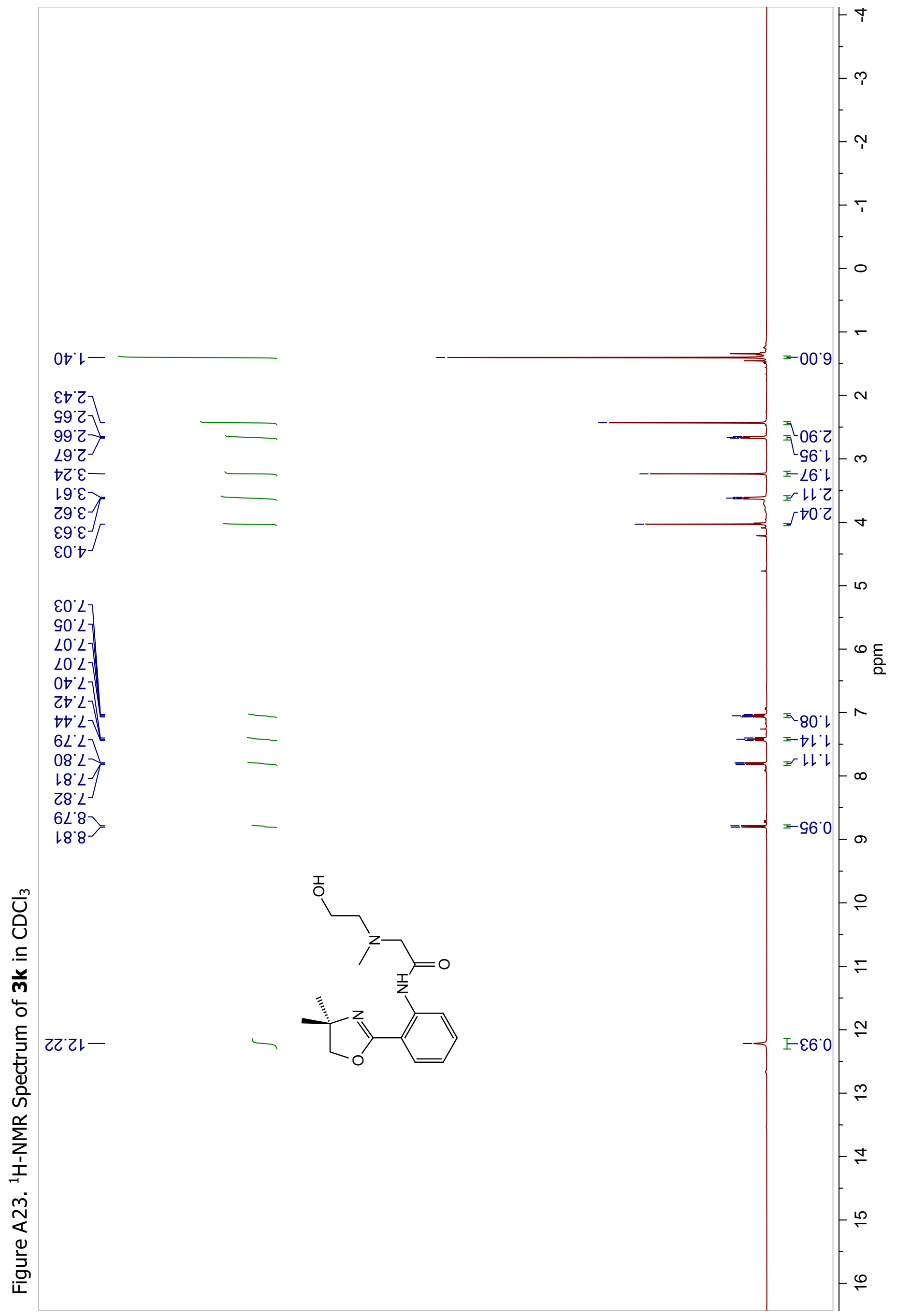




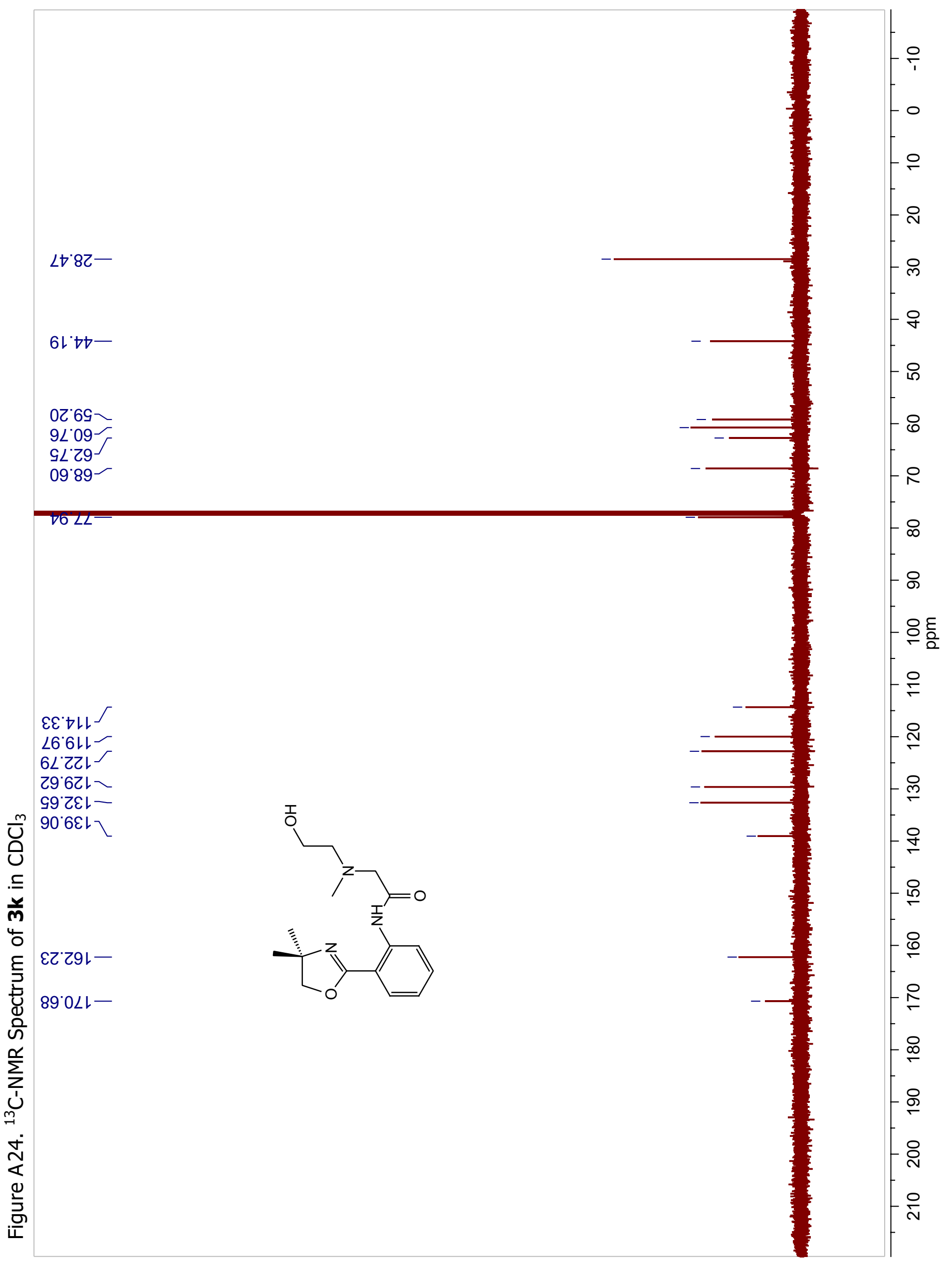




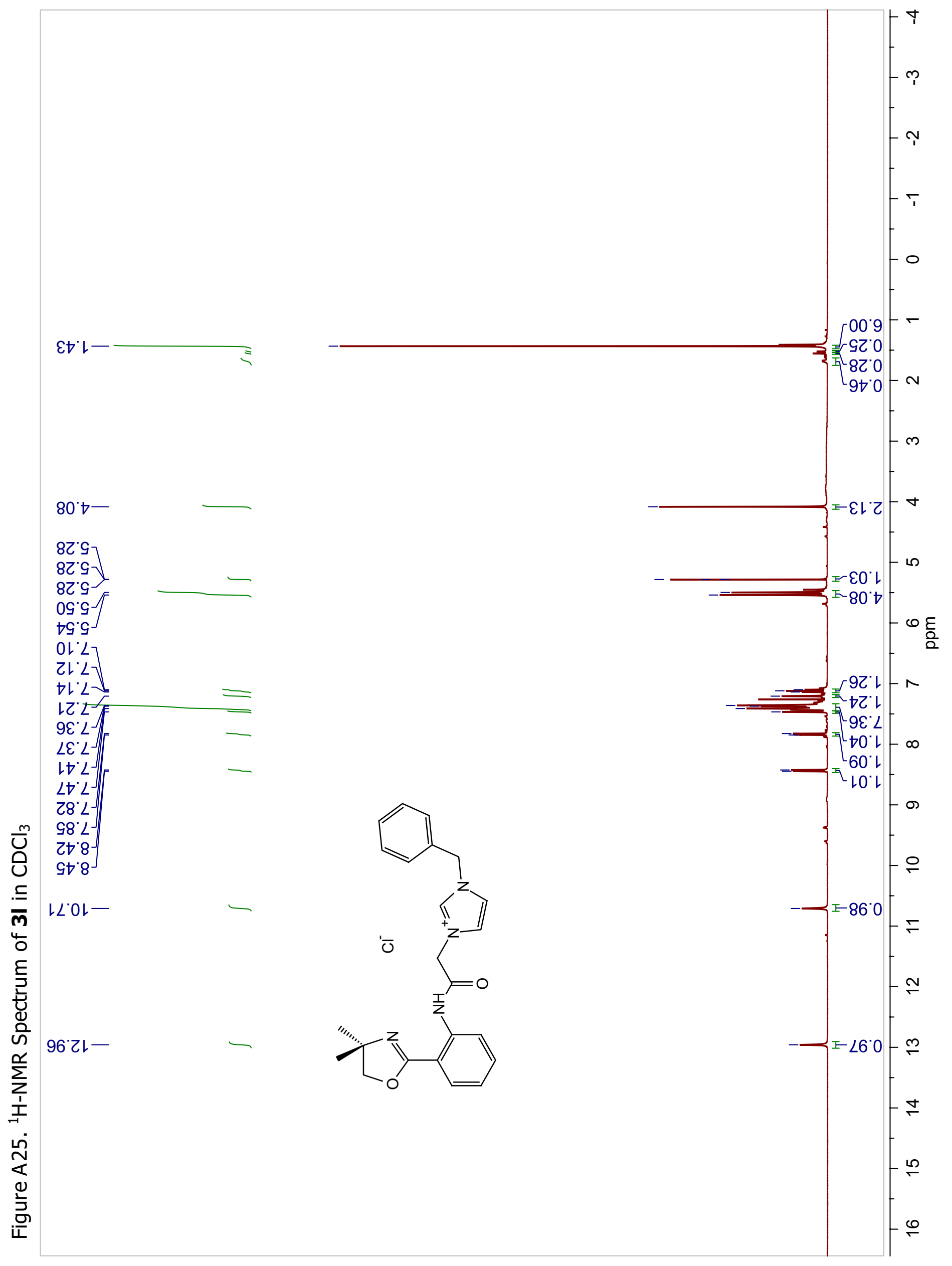




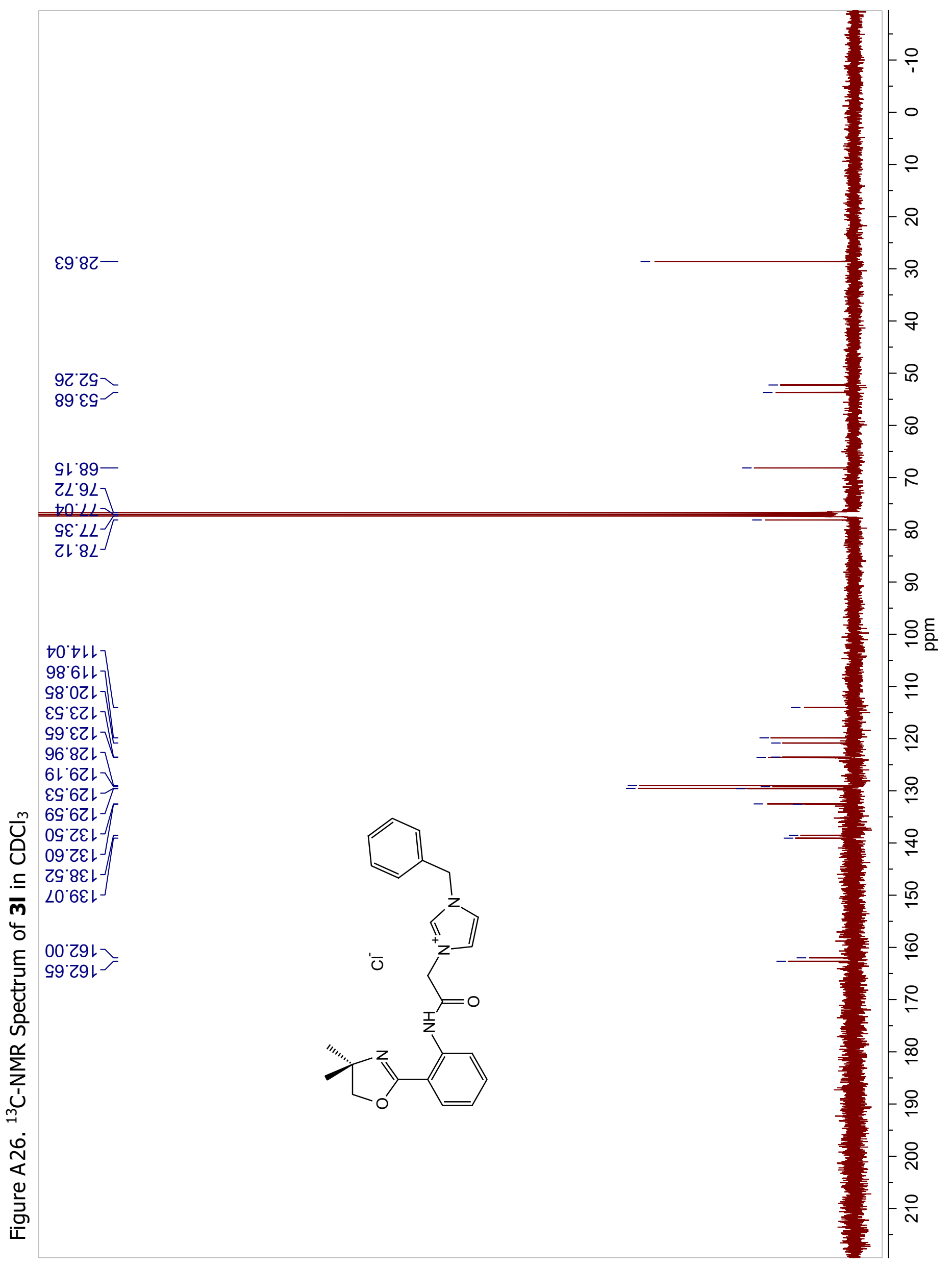




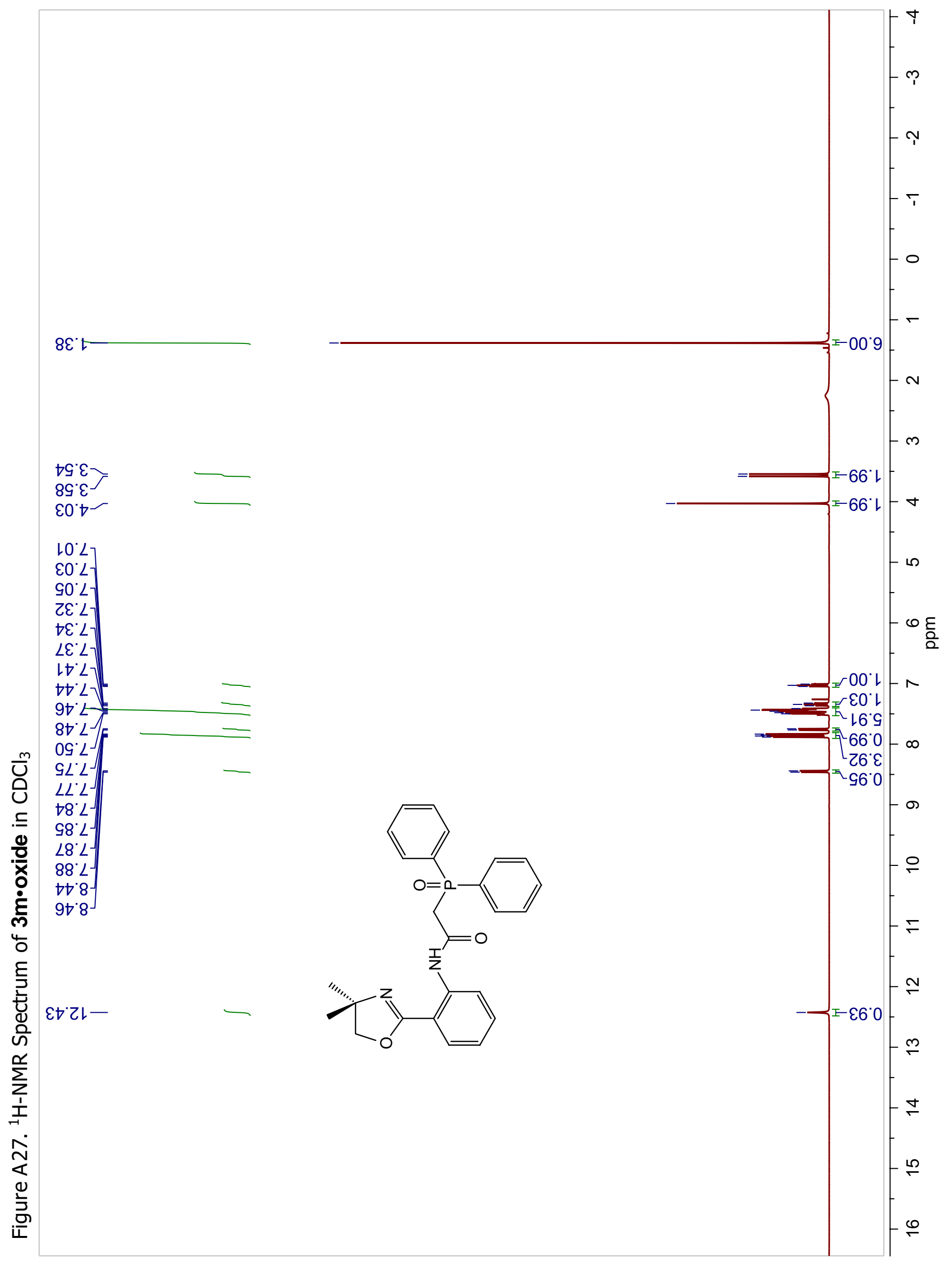




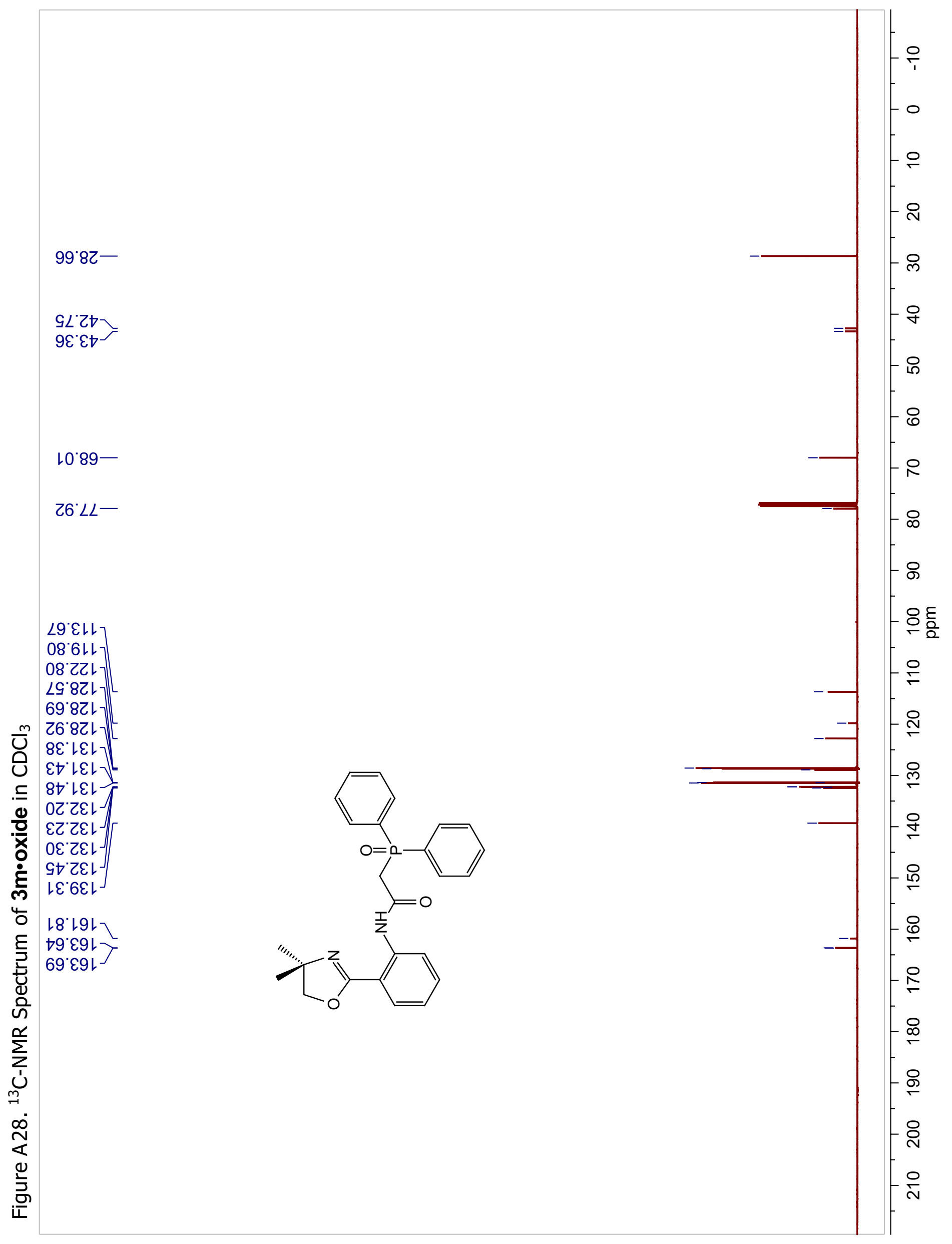




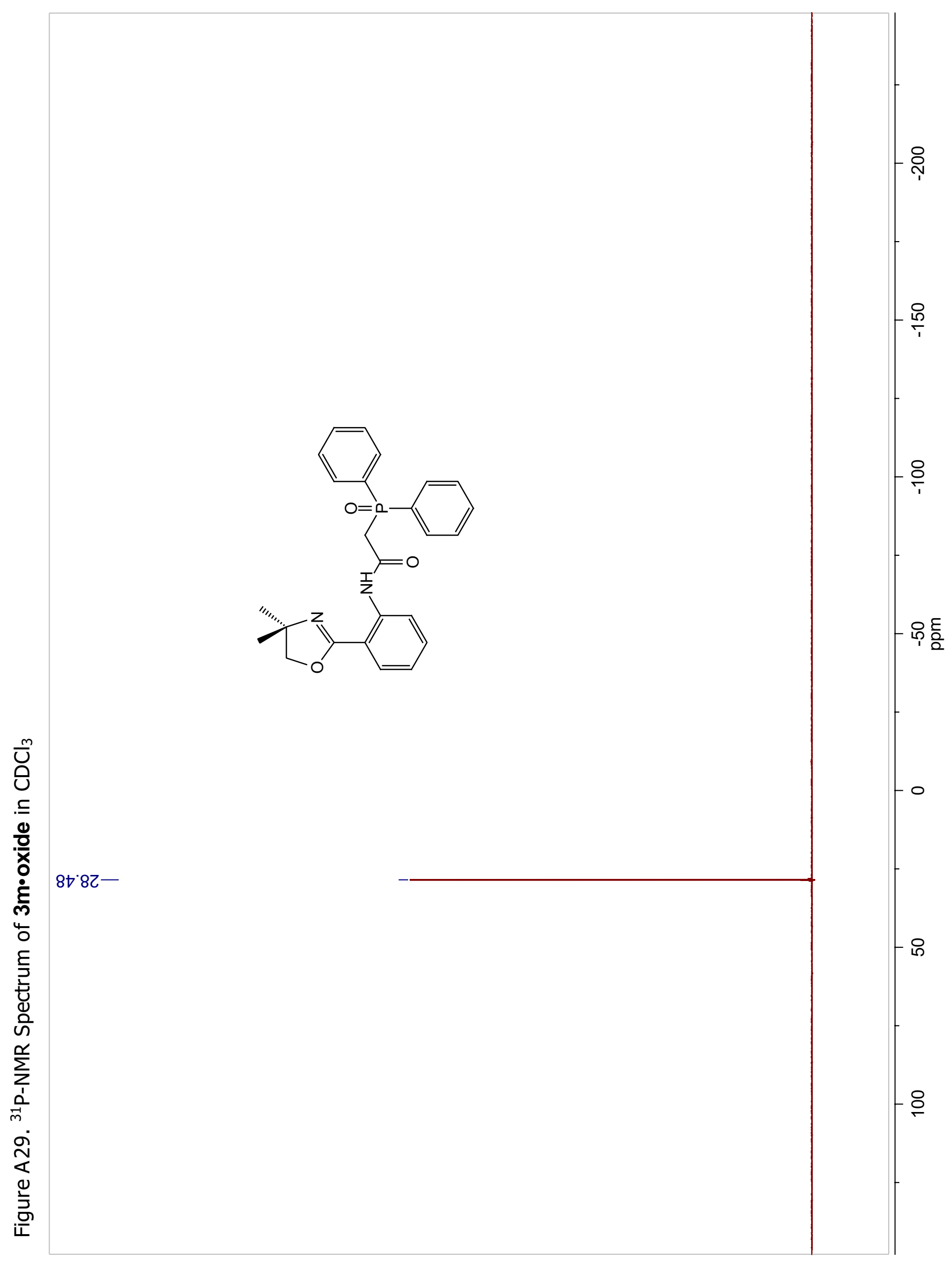




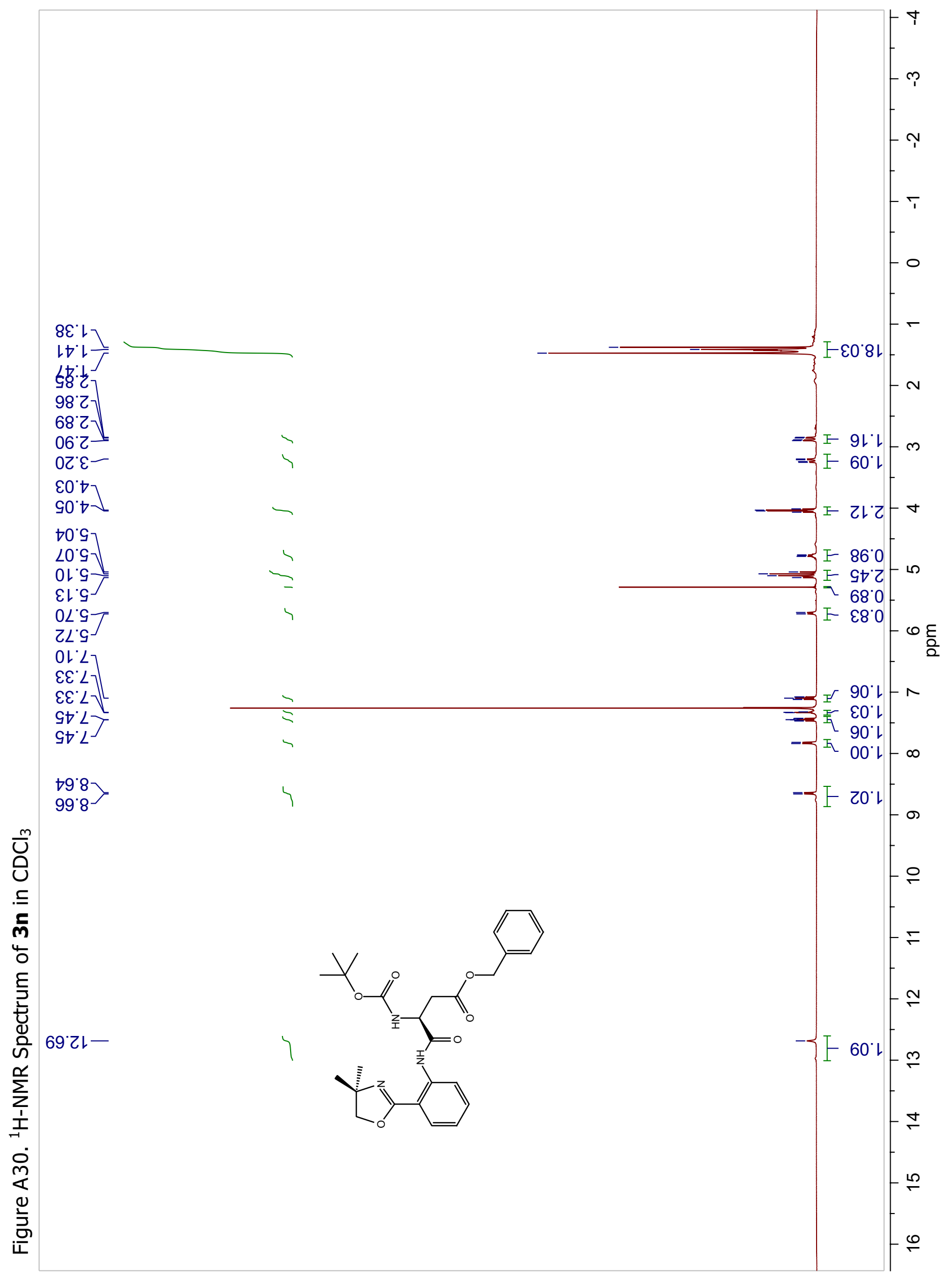




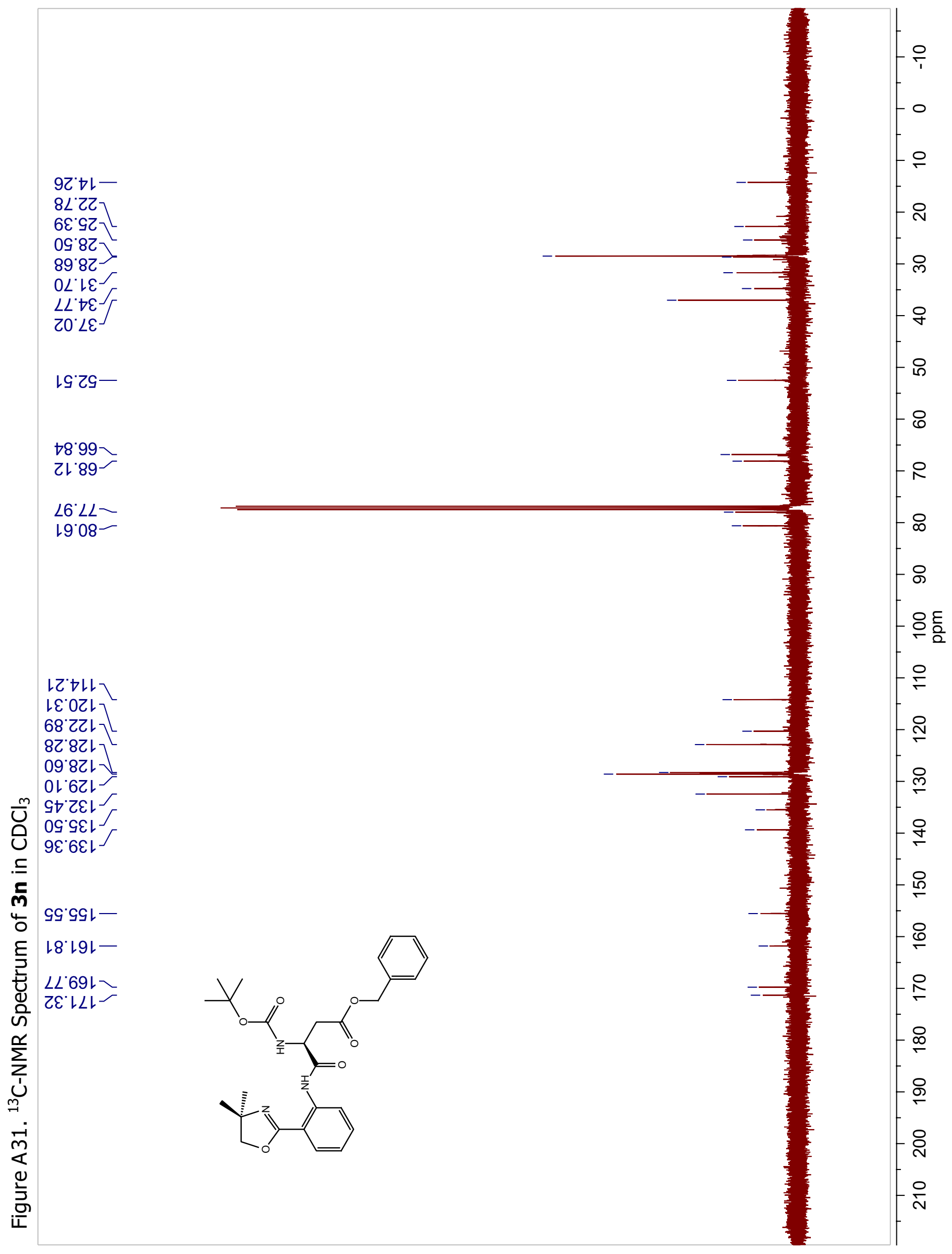




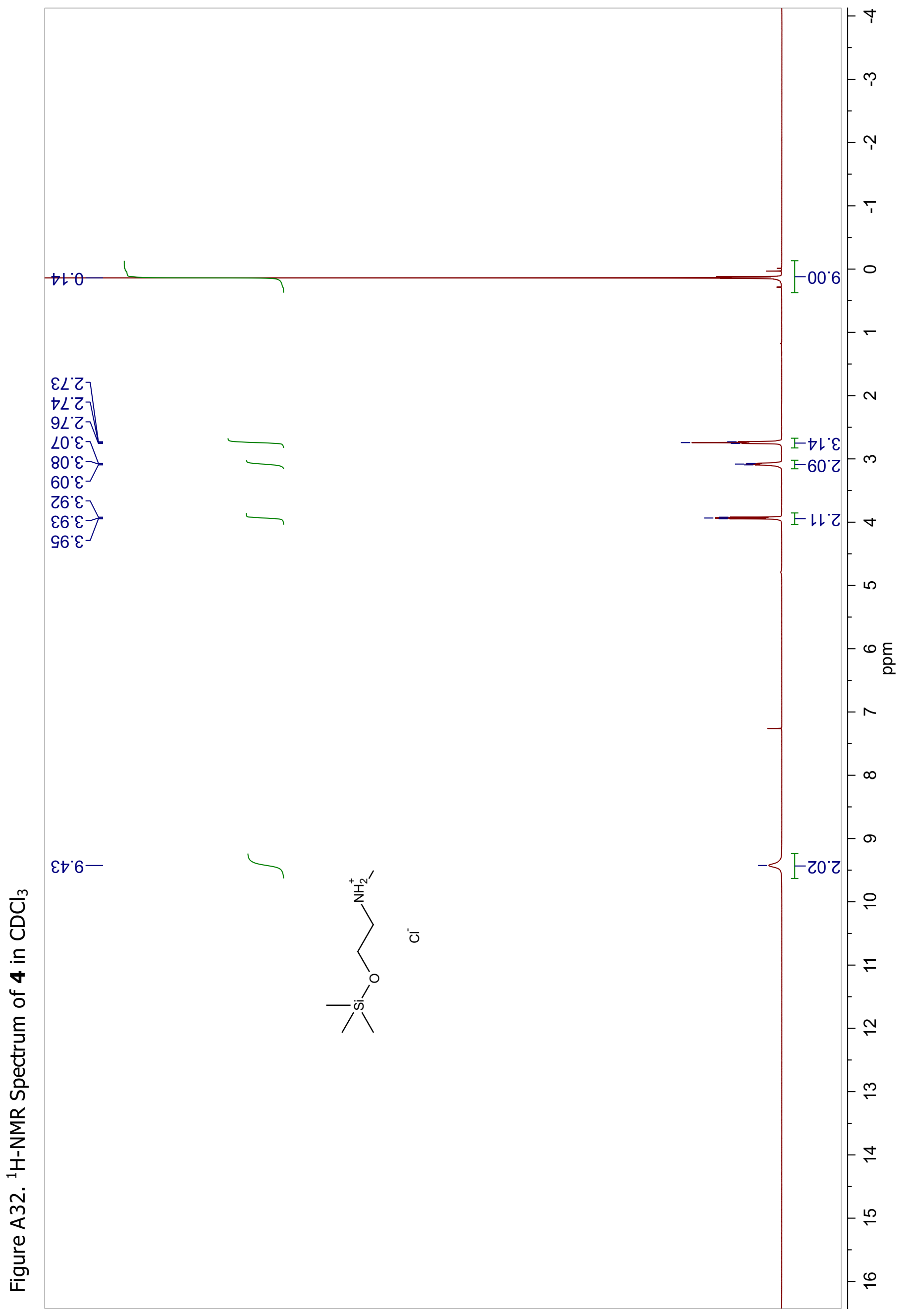




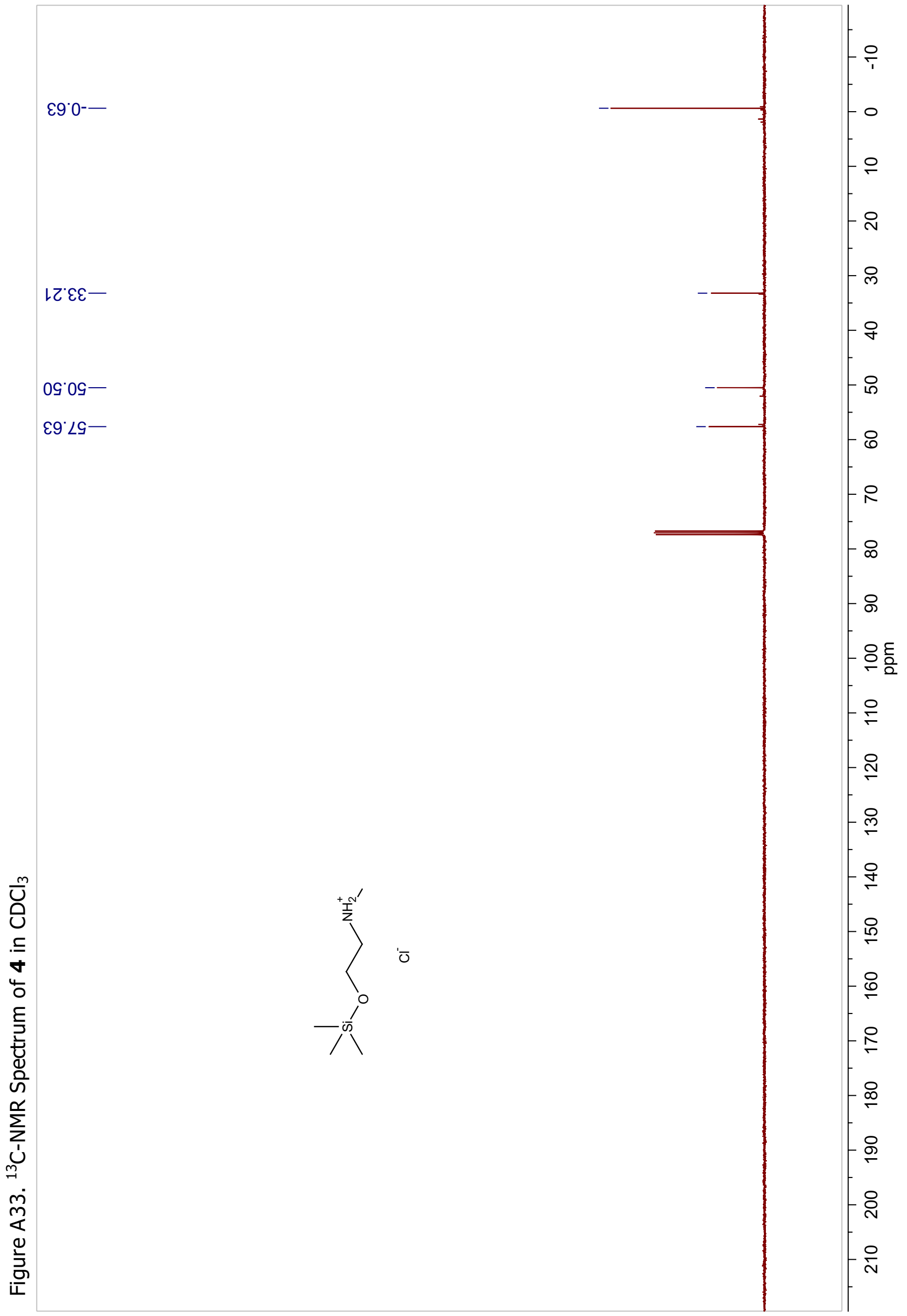




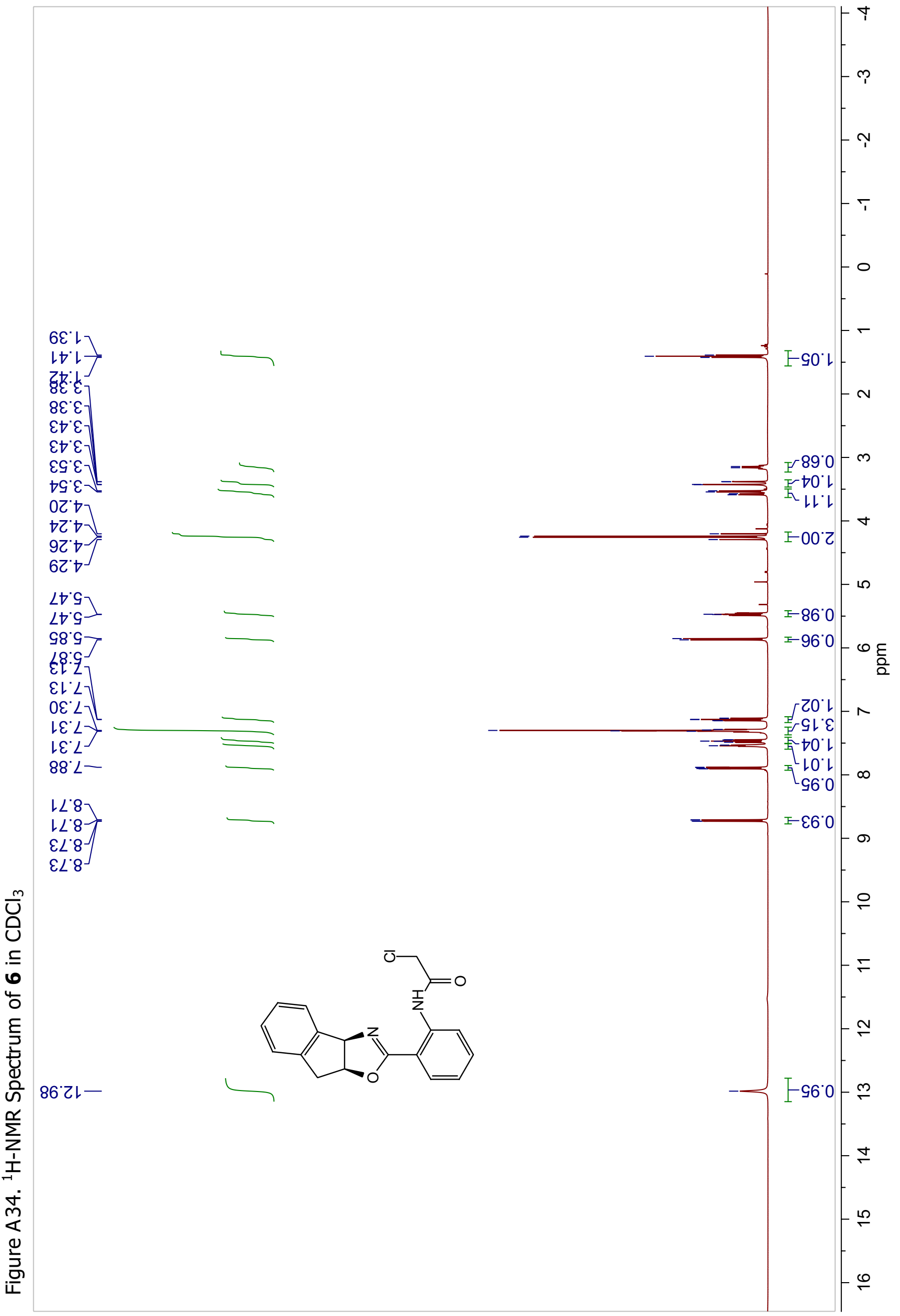




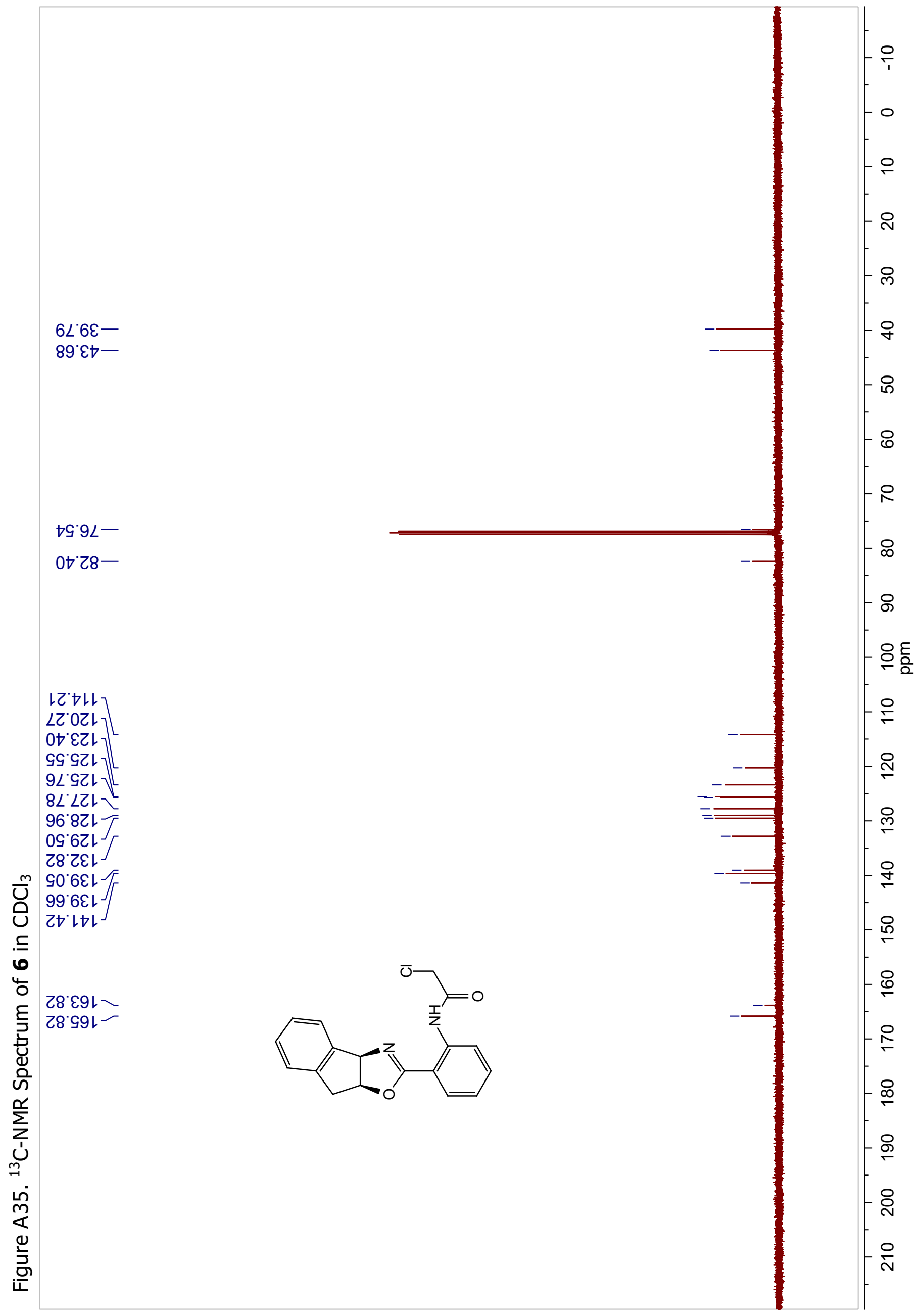




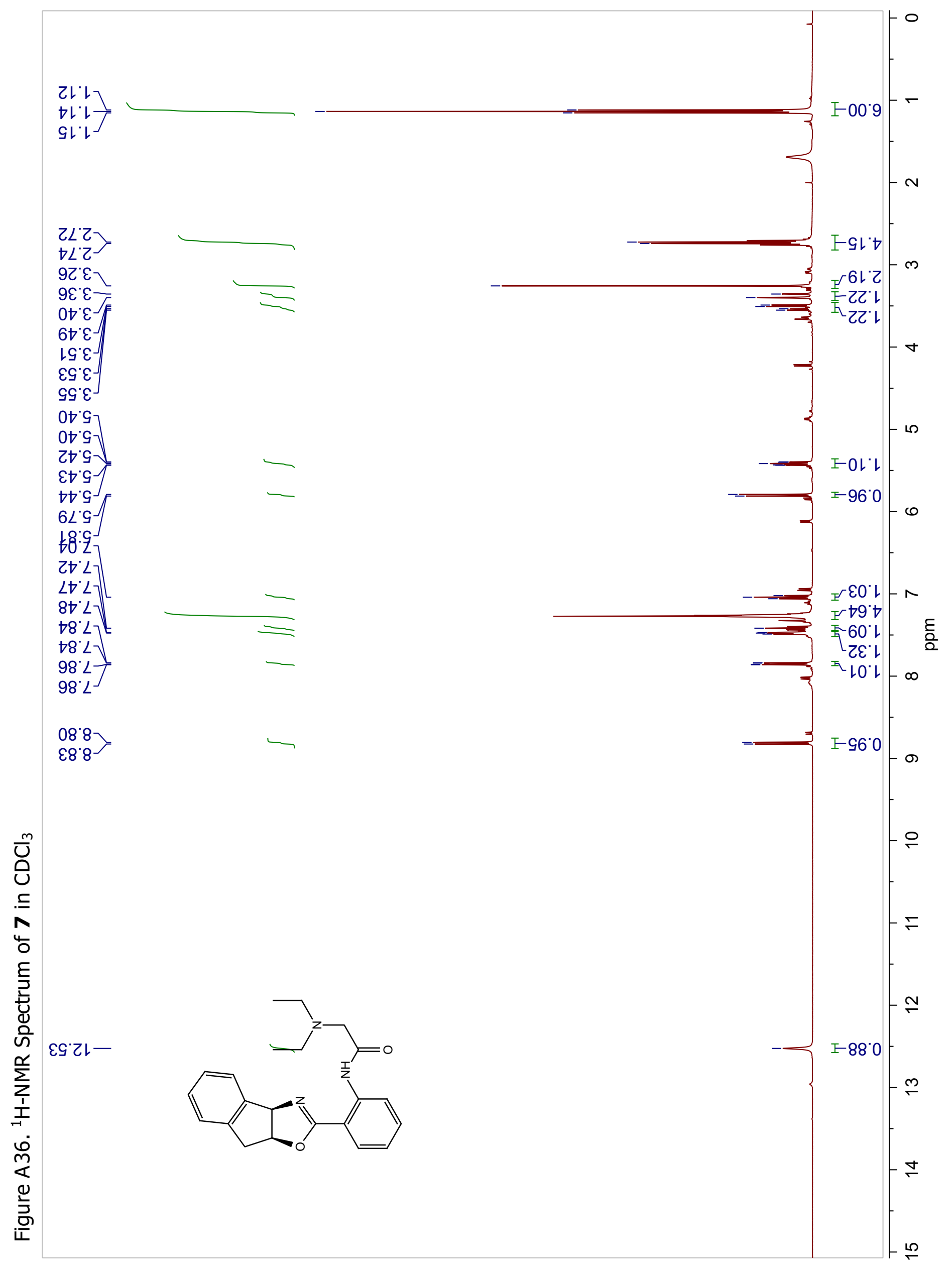




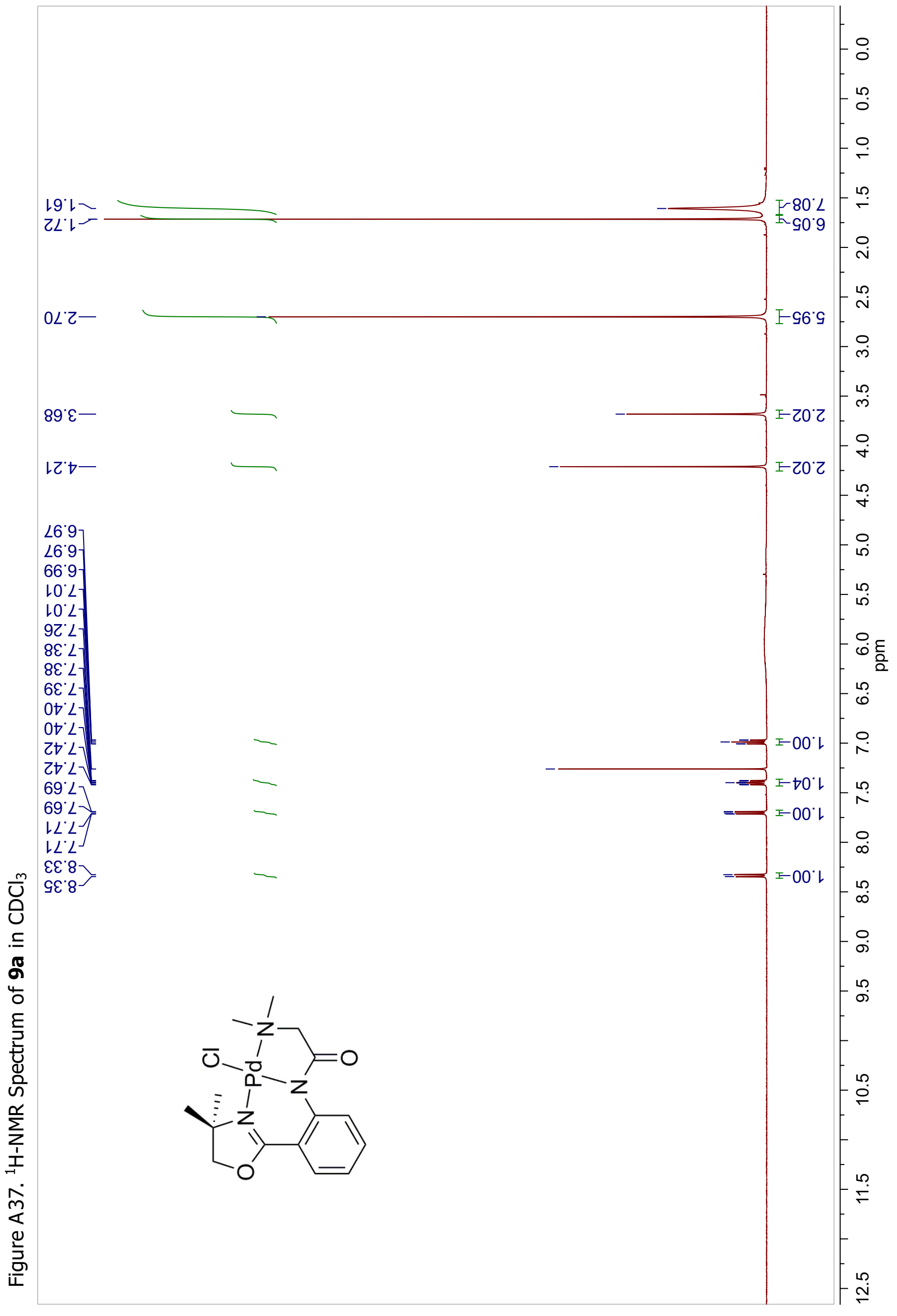


$06: 2 Z-$

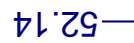

S90L】
ZZ'Lレ

$67 \cdot 18$

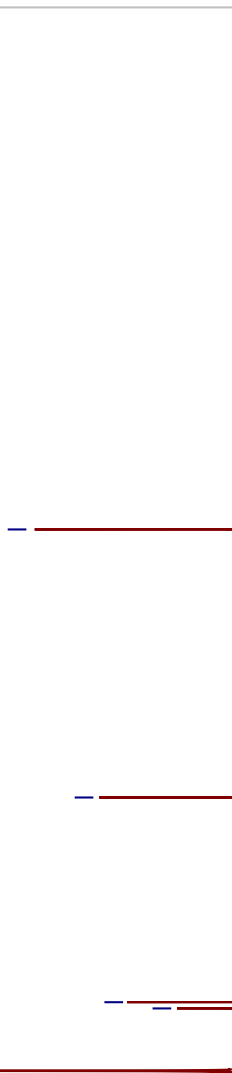

$-\frac{0}{1}$

-

으

요

요

우

우

8

옹

$\infty$

우

Lt9ル1

†6レZレ

0†とてレ

SL'6ZL

9l'EEL

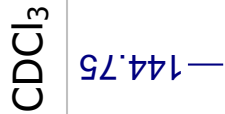

.

ธั

पั 69'291-

壱

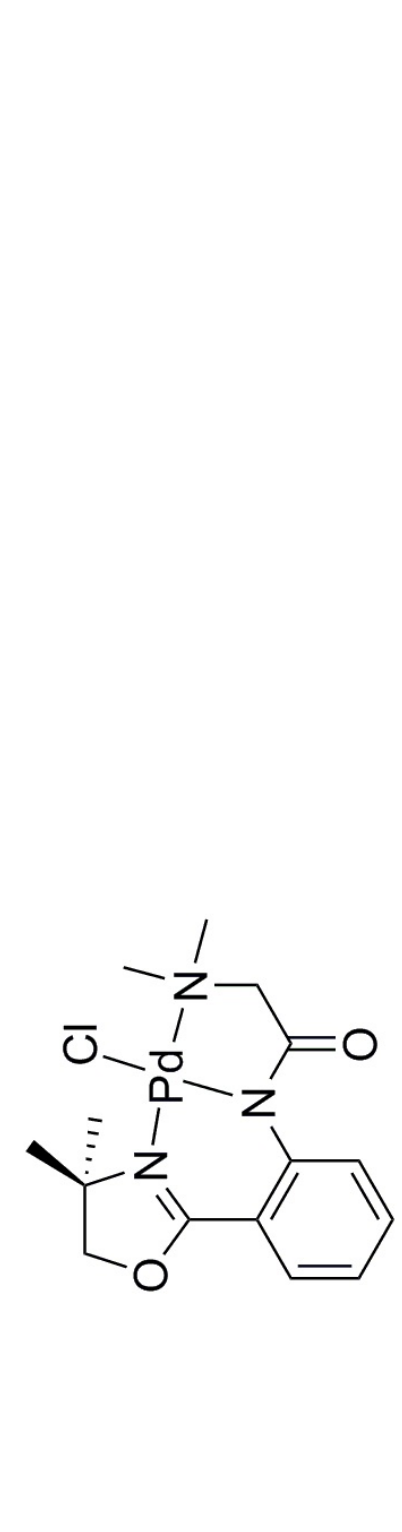

웅틍

읃

$\sum_{j}^{\infty}$

نे

$\stackrel{\infty}{m}$

임

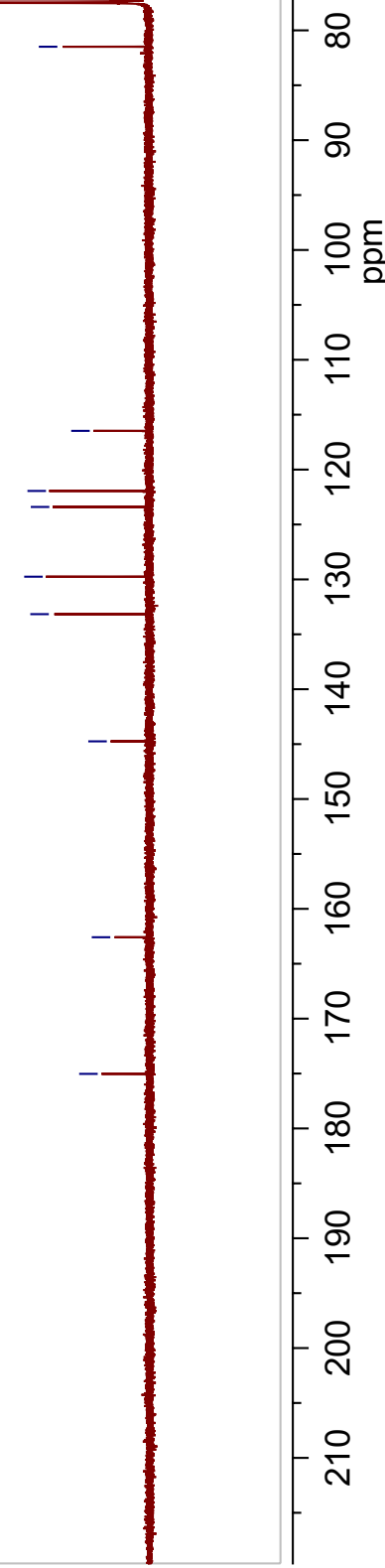




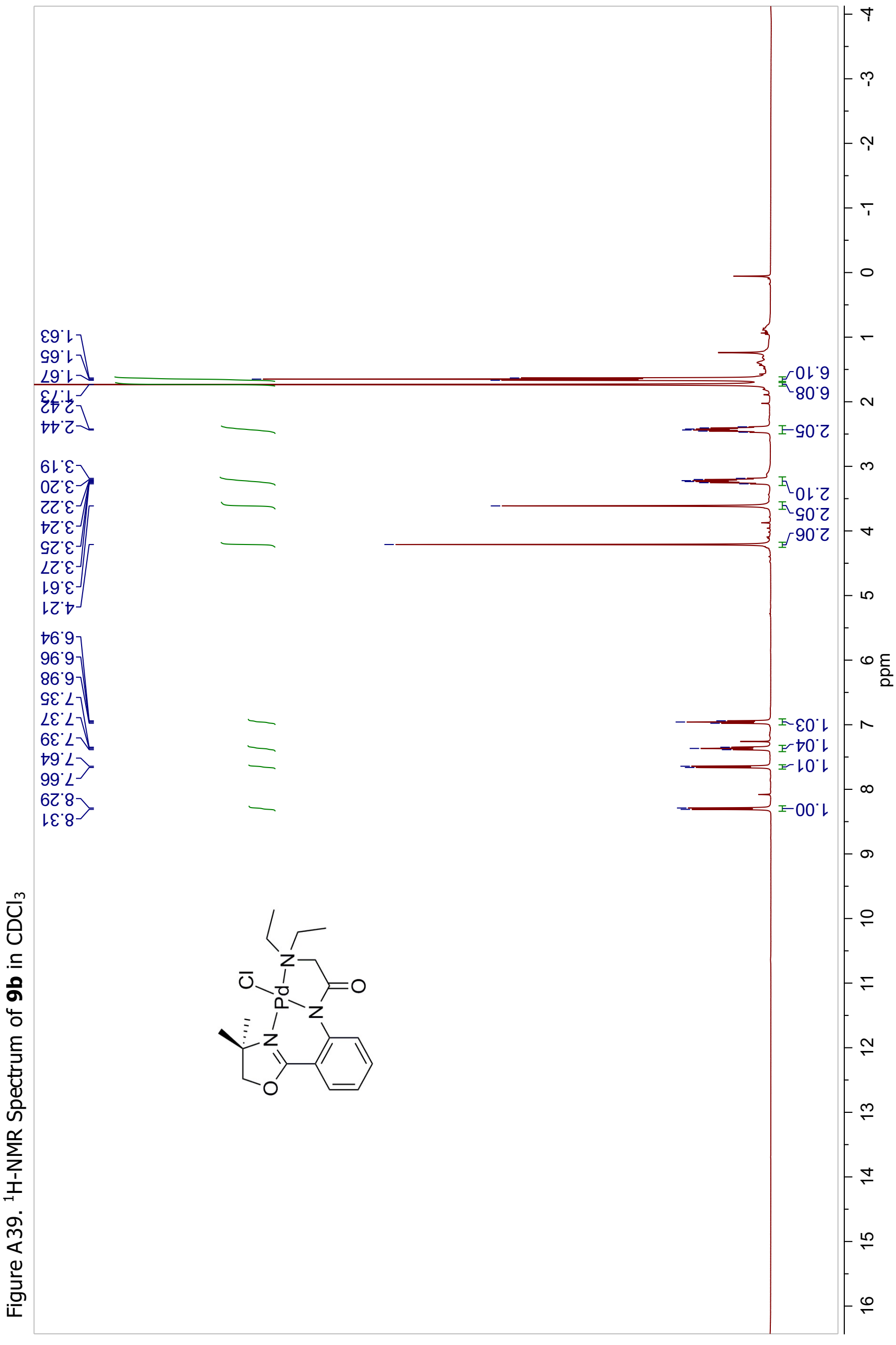


Sカてレー

$\angle 8 \angle Z-$

s9.99
$69^{\circ} \varepsilon 9-$
$29 \cdot 0<$

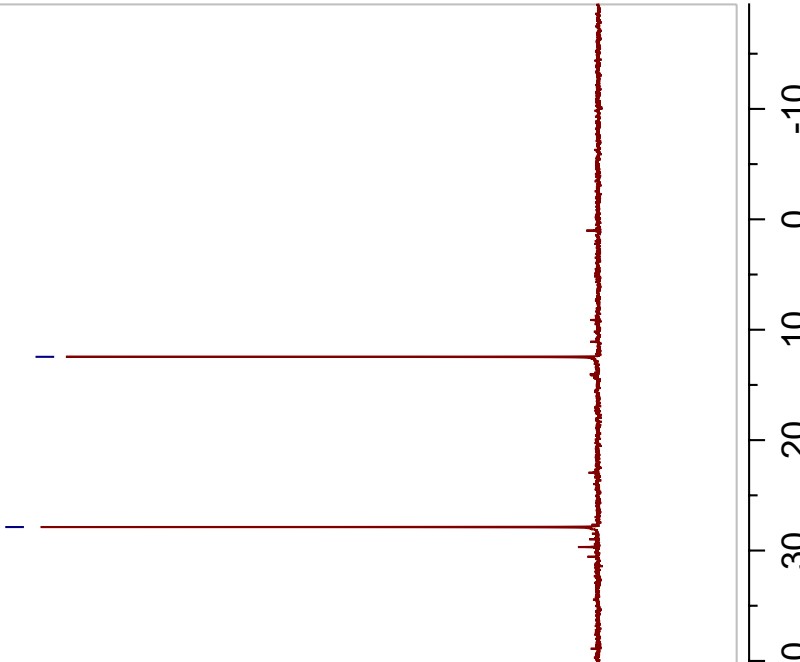

운

o

으

우

요

우

요

8

옹

SG'เ8-

カ7・9レー

เ9.ルL

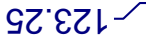

$99^{\prime} 6$ 6 ○

06'Zعᄂ

บับ

89・カーー

.

ด

ডั0 str29l-

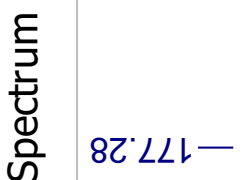

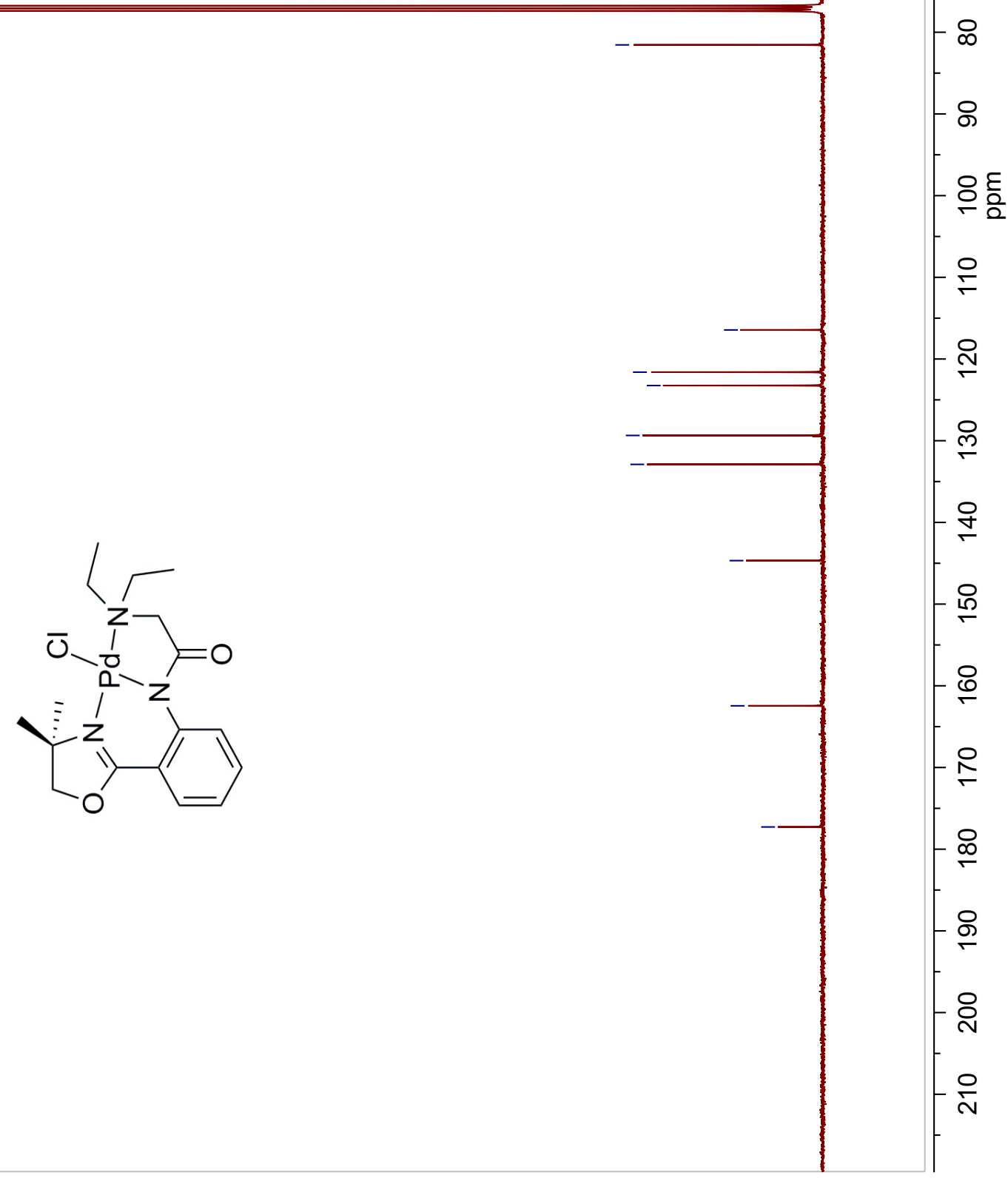

$\sum_{\substack{j \\ j}}^{\infty}$

广ั่

(1)

高 
Gนレ

89'

9L'

छह है:

$\left.90^{\circ} \varepsilon\right]$

$\left.9 L^{\circ} \varepsilon\right]$

$Z \nabla^{\circ} \varepsilon$

GS' $\mathcal{L}$

$\varepsilon L^{\prime} \varepsilon-$

乙8. $\varepsilon^{-}$

$02+5$

sE'

$69 \circ$

$6 L^{\circ} \nabla$

08.

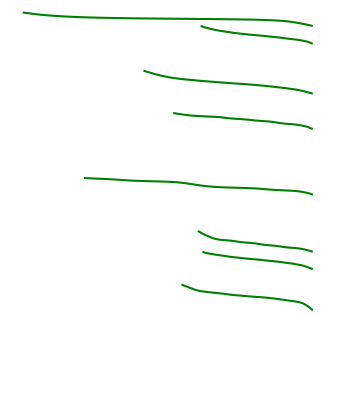

96.9

$90<\sqrt{2}$

$Z \varepsilon^{\circ} L \backslash$

$87^{\circ} \mathrm{LC}$

69. 25

$87^{\circ} 8$

$19^{\circ}$

$L^{\circ} 6$
$\varepsilon L^{\circ}$

仓ับ

ֻั

ด

4

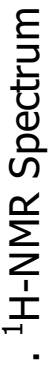
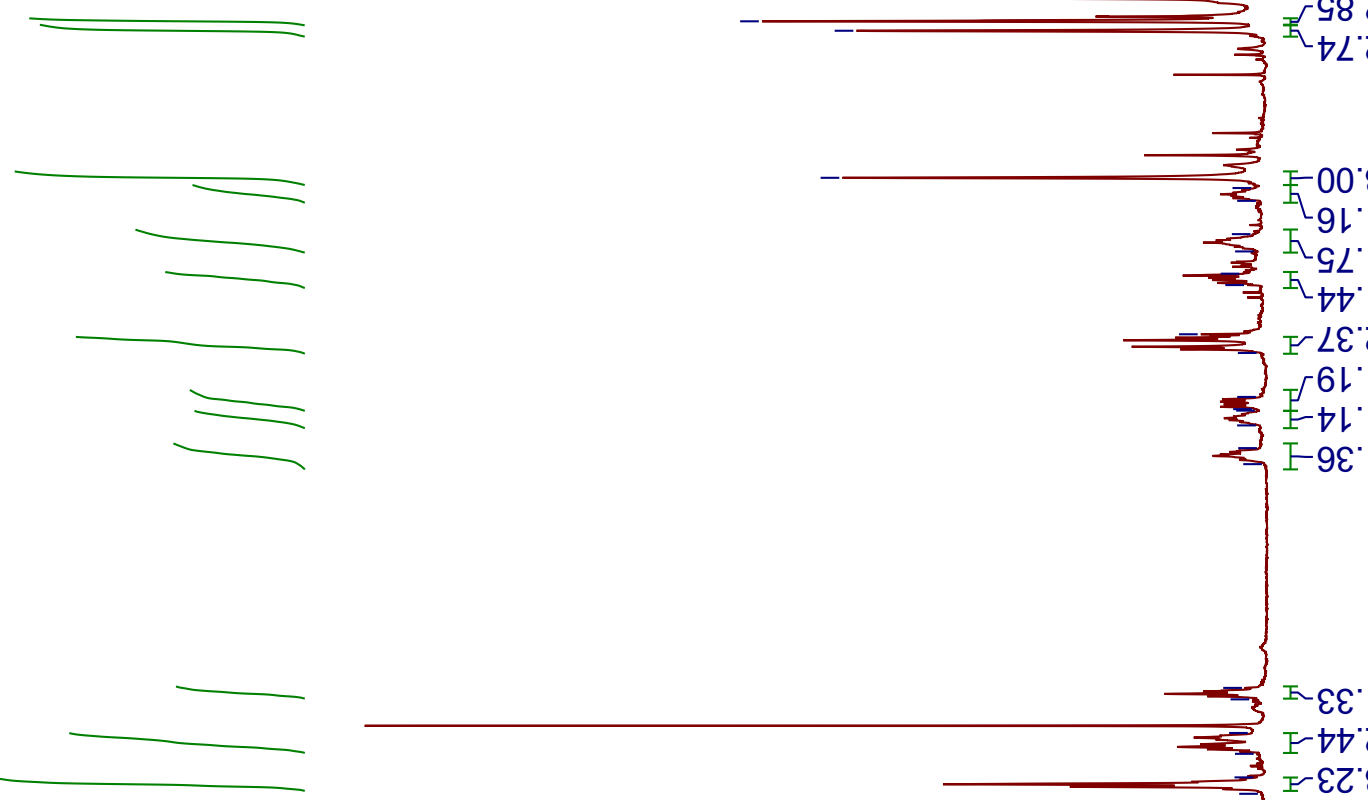

98

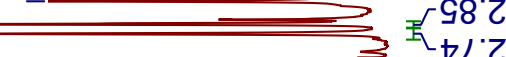

$-N$

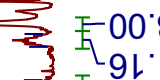

m

-

瓦詁

$\checkmark$

$F \angle \varepsilon^{\prime} Z$

$-r^{6 L}$

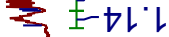

เ

$\leftrightharpoons F-9 \varepsilon^{\circ} L$

을

安

2

$F$

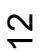<smiles>[2H]P1CC(=O)C[Z]1(C)C</smiles>

음

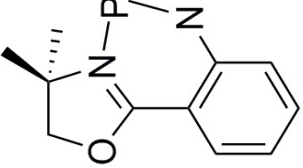

$\stackrel{m}{\sim}$

$\underset{\nabla}{ }$

$\stackrel{20}{\square}$

흔 


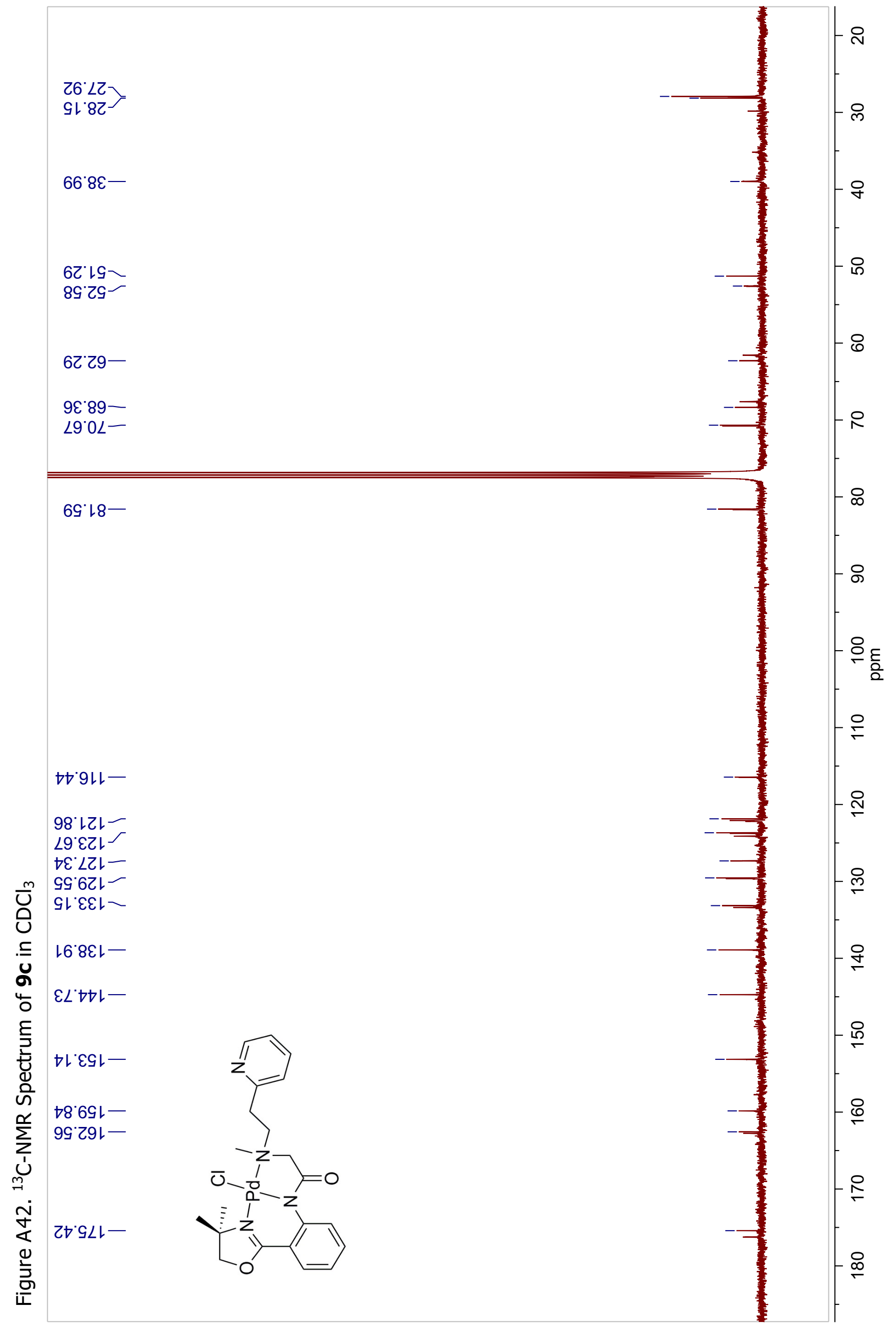




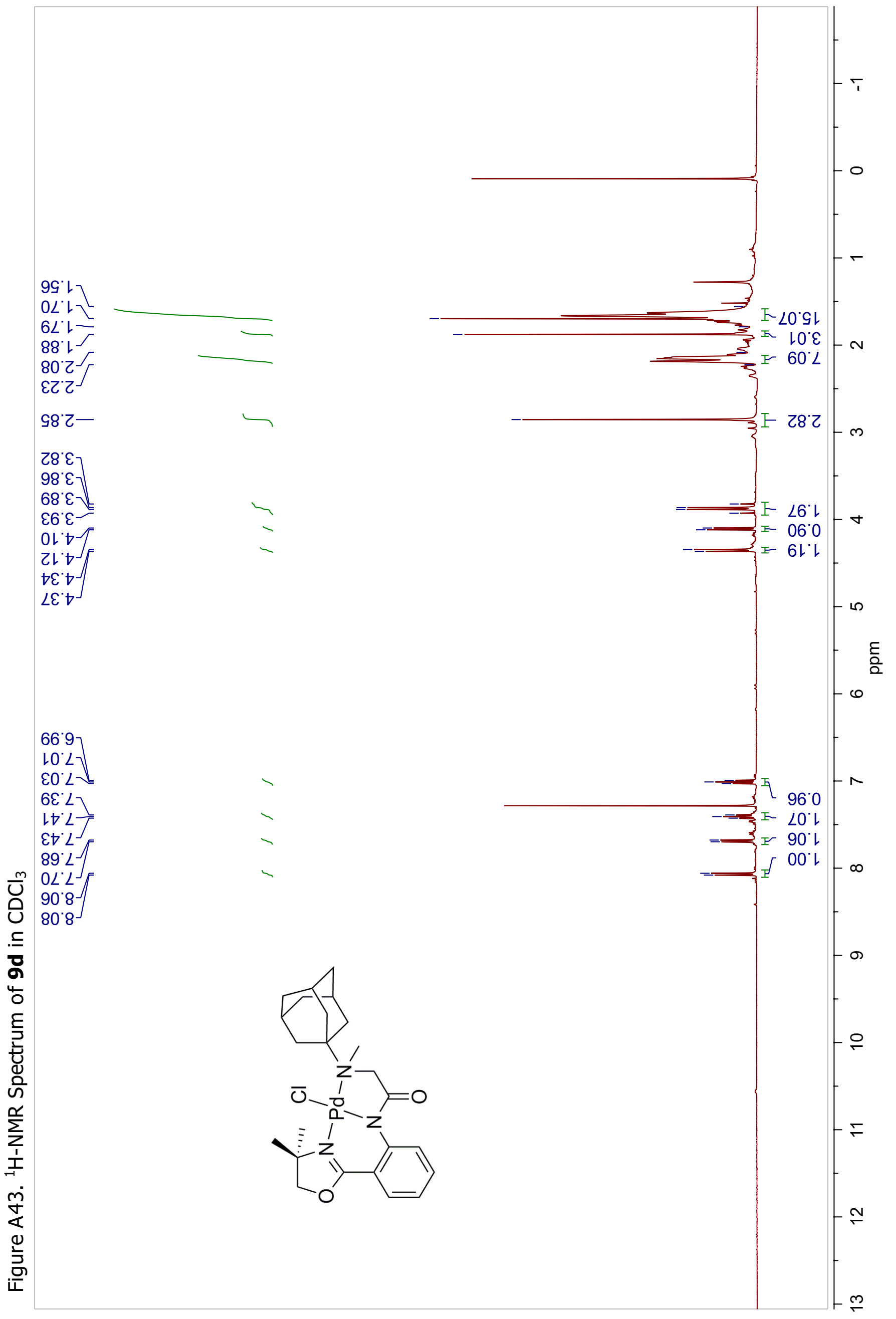


S9.2Z

89.82 厅

$\varepsilon Z^{\circ} 0 \varepsilon^{-}$

$90.9 \varepsilon^{-}$

$86^{\circ} 8 \varepsilon^{-}$

$L \angle \angle D C$

レでゥ9-

90.29

$16.02-$

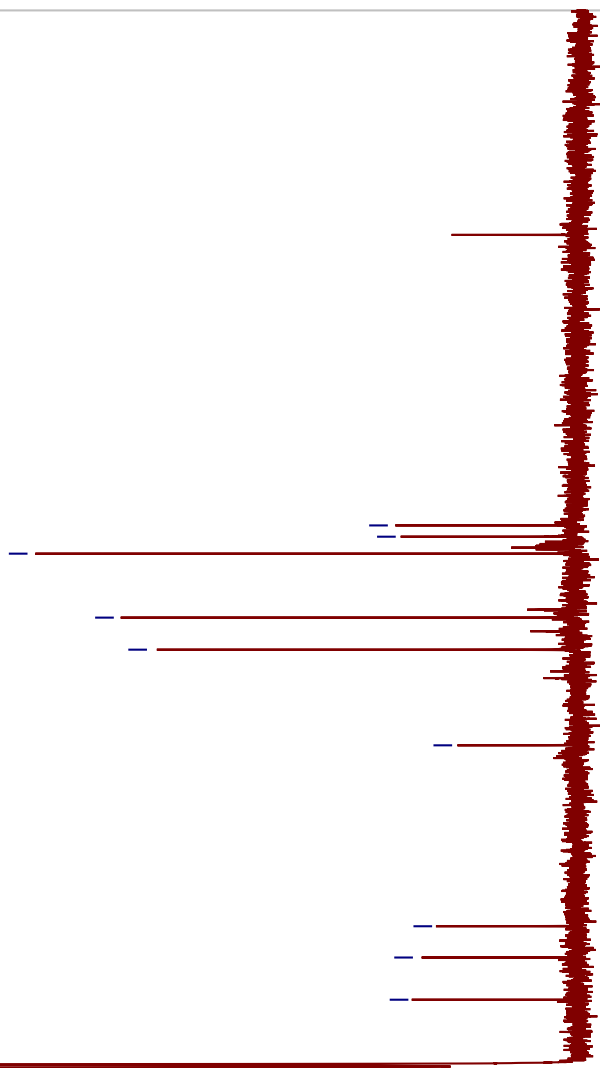

$20 \cdot 28$

七七゙டルー

ZLレZト

66 ZZレ

†七 6Zレ -

8เ'EEL -
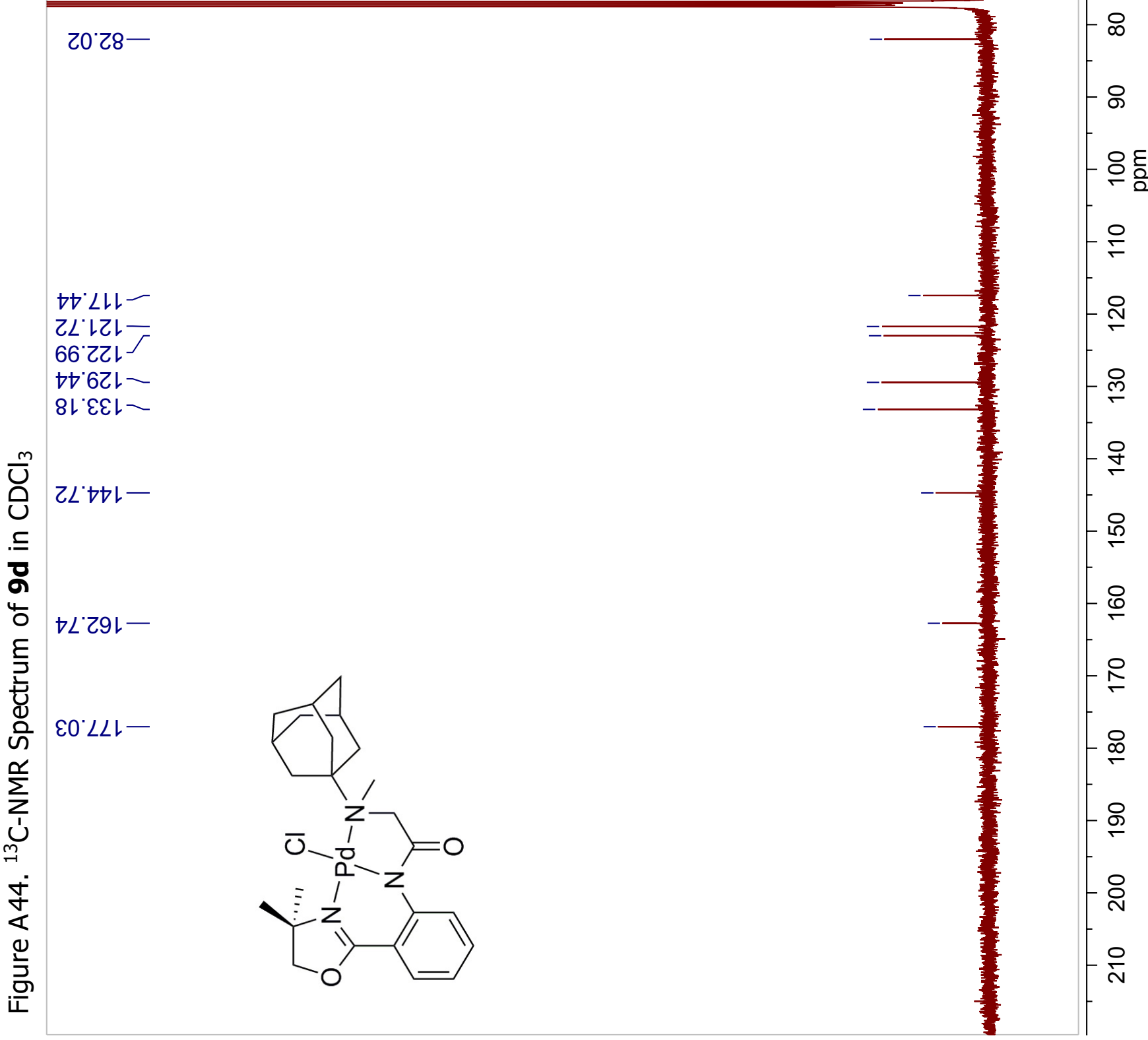


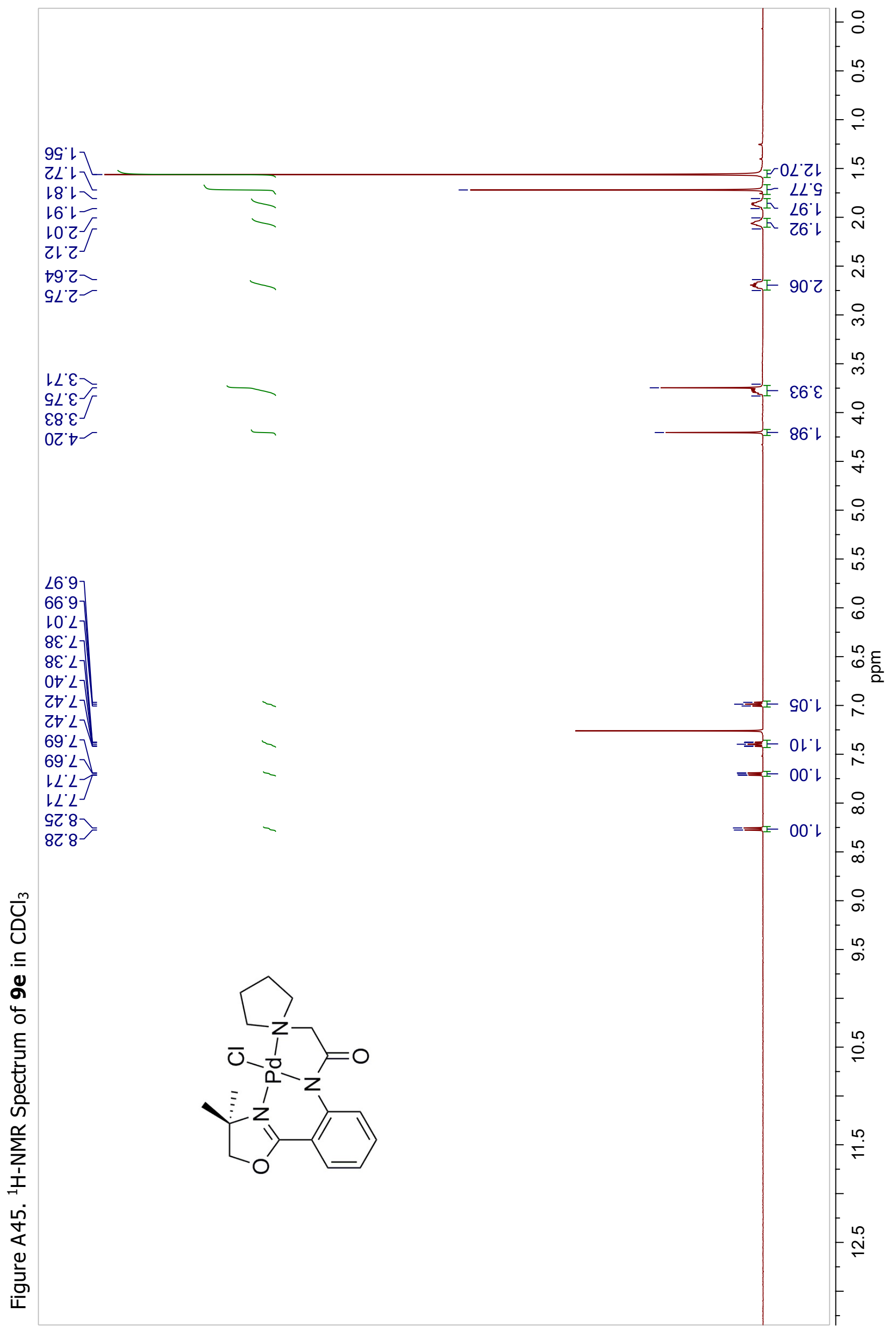




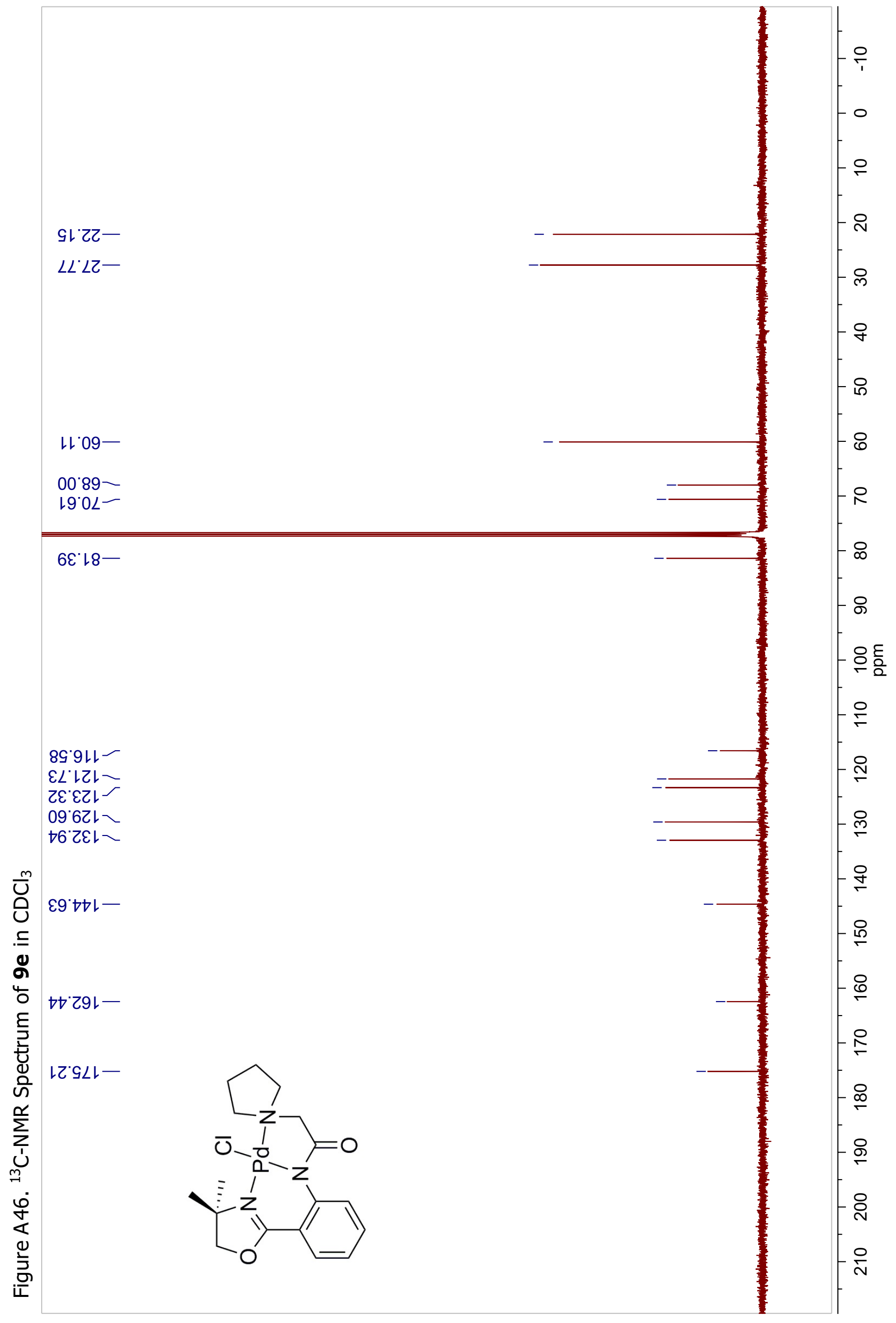




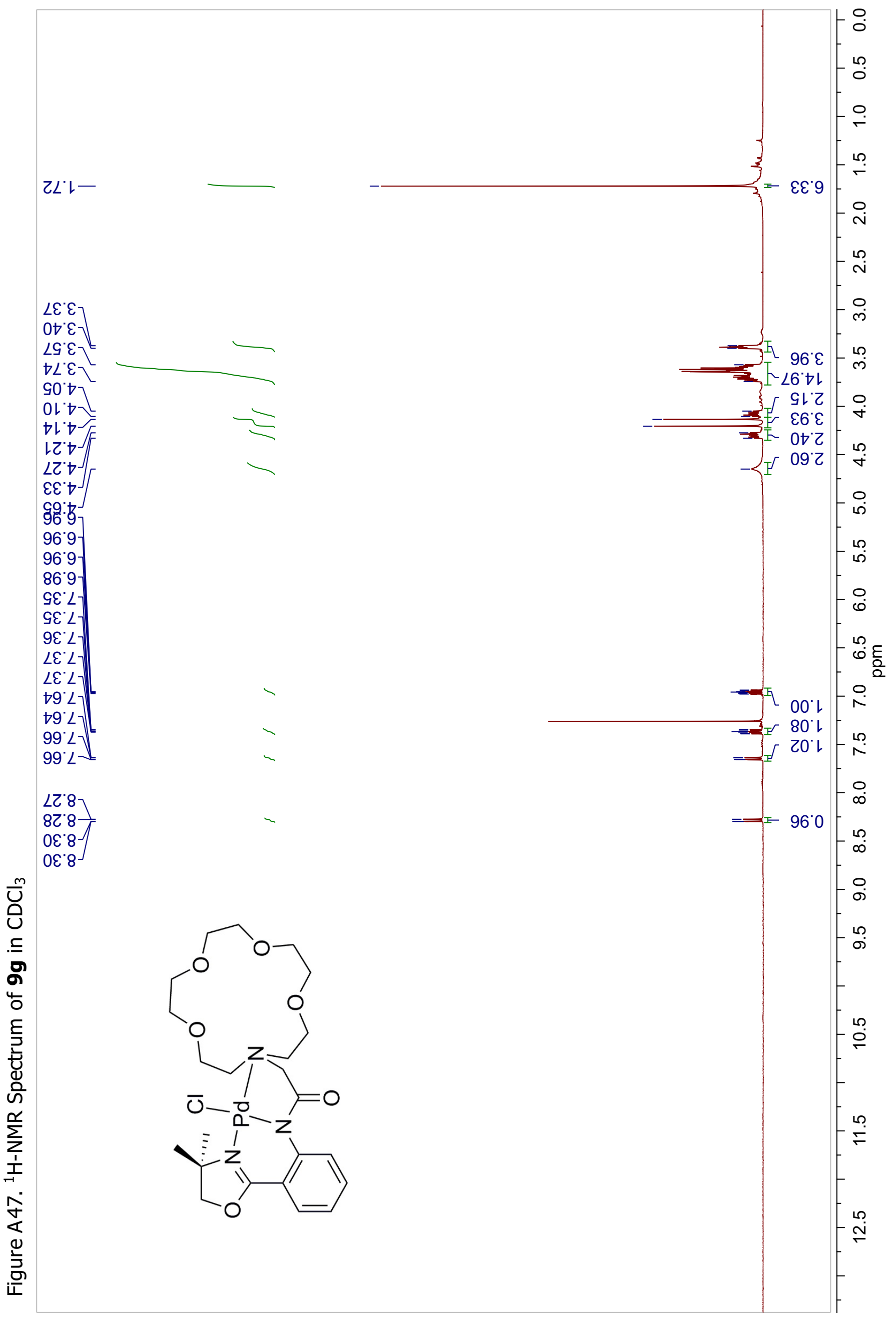




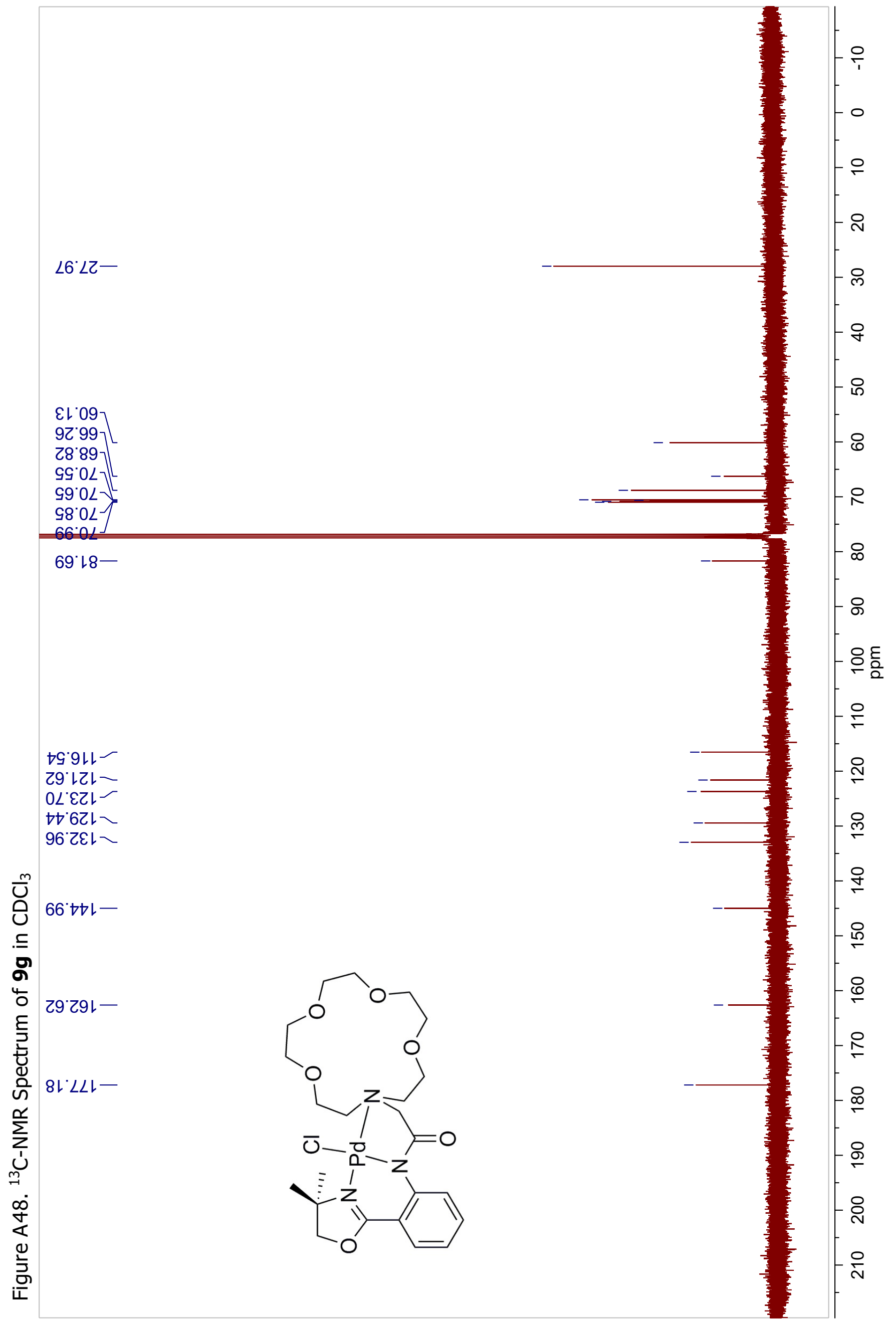




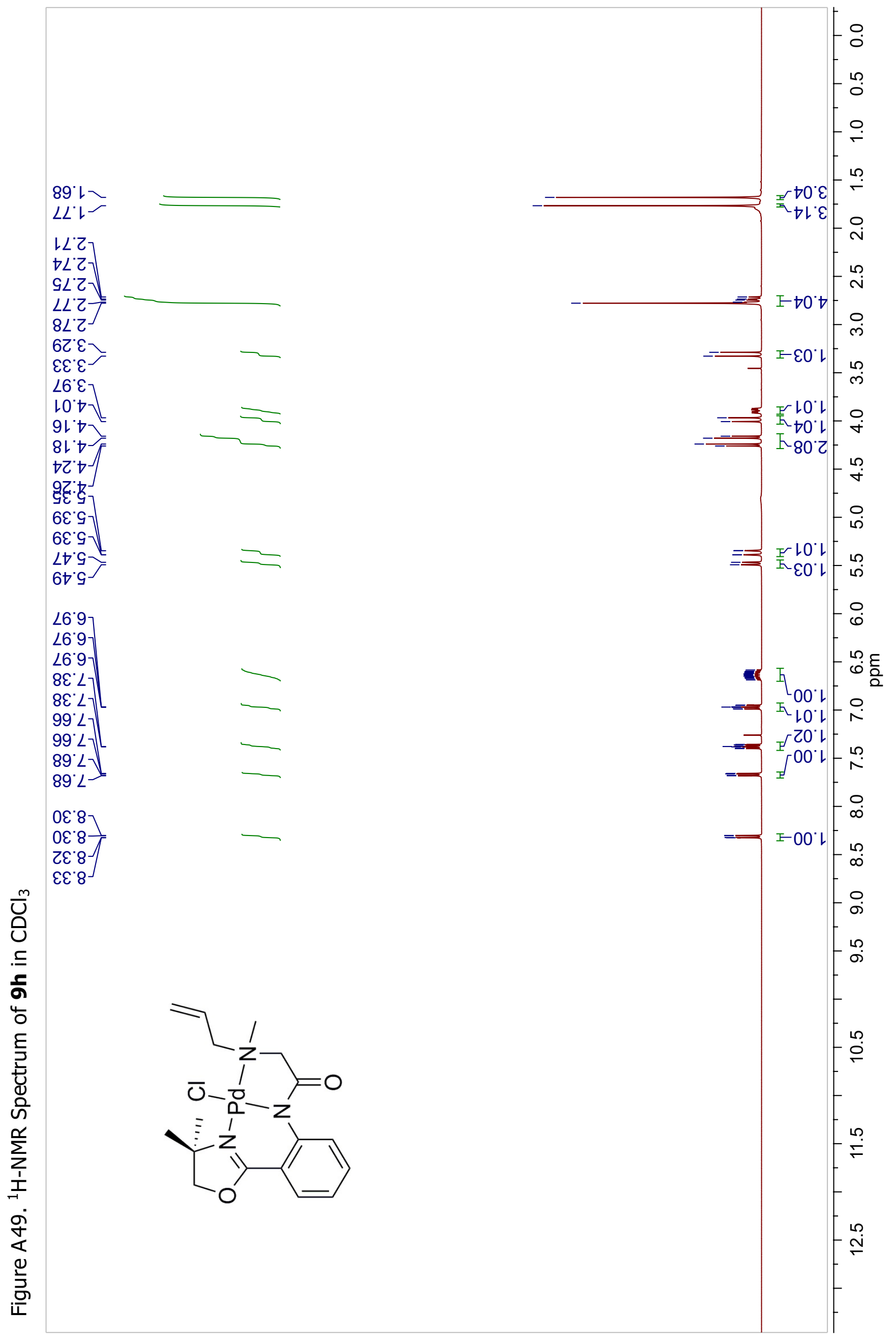




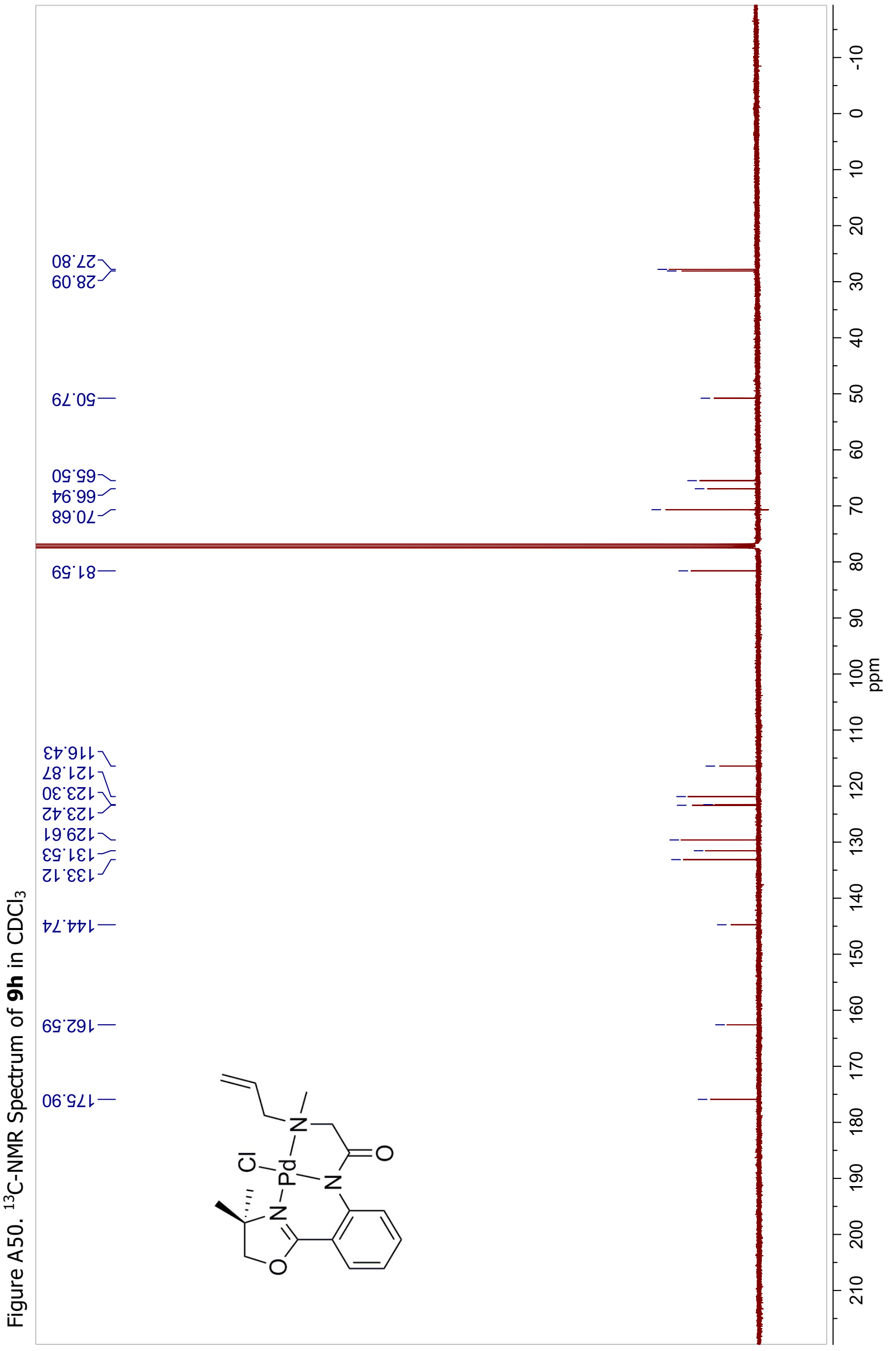




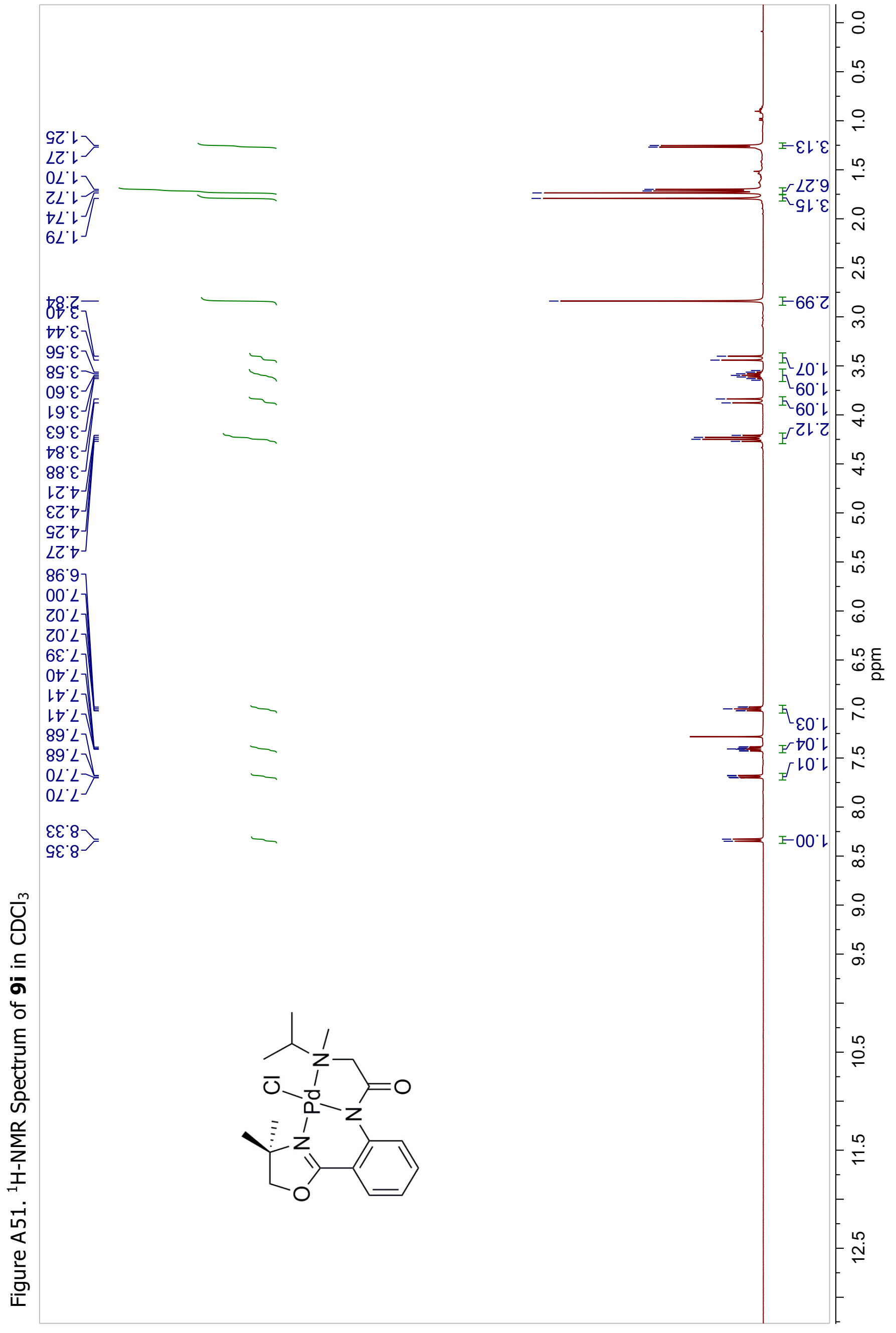


89.91-

$\angle D^{\circ} 0 Z$ -

$0 L \angle Z$

$06: 2 Z$

$19^{\circ} \angle t^{\top}$

St'EG-

$87^{\circ} 69$ ר

乙ย' 29

E. $0 L-$

29.18-

679ルレ

69レてレ

てと'ยてレ

6ย'6ZL

06'ZEL

บับ $\varepsilon 9^{\circ} t t レ-$

ᄃ

ส

吹レて9レー

壱

$\sum_{\substack{1 \\ \text { ju }}}^{\infty}$

กิ่
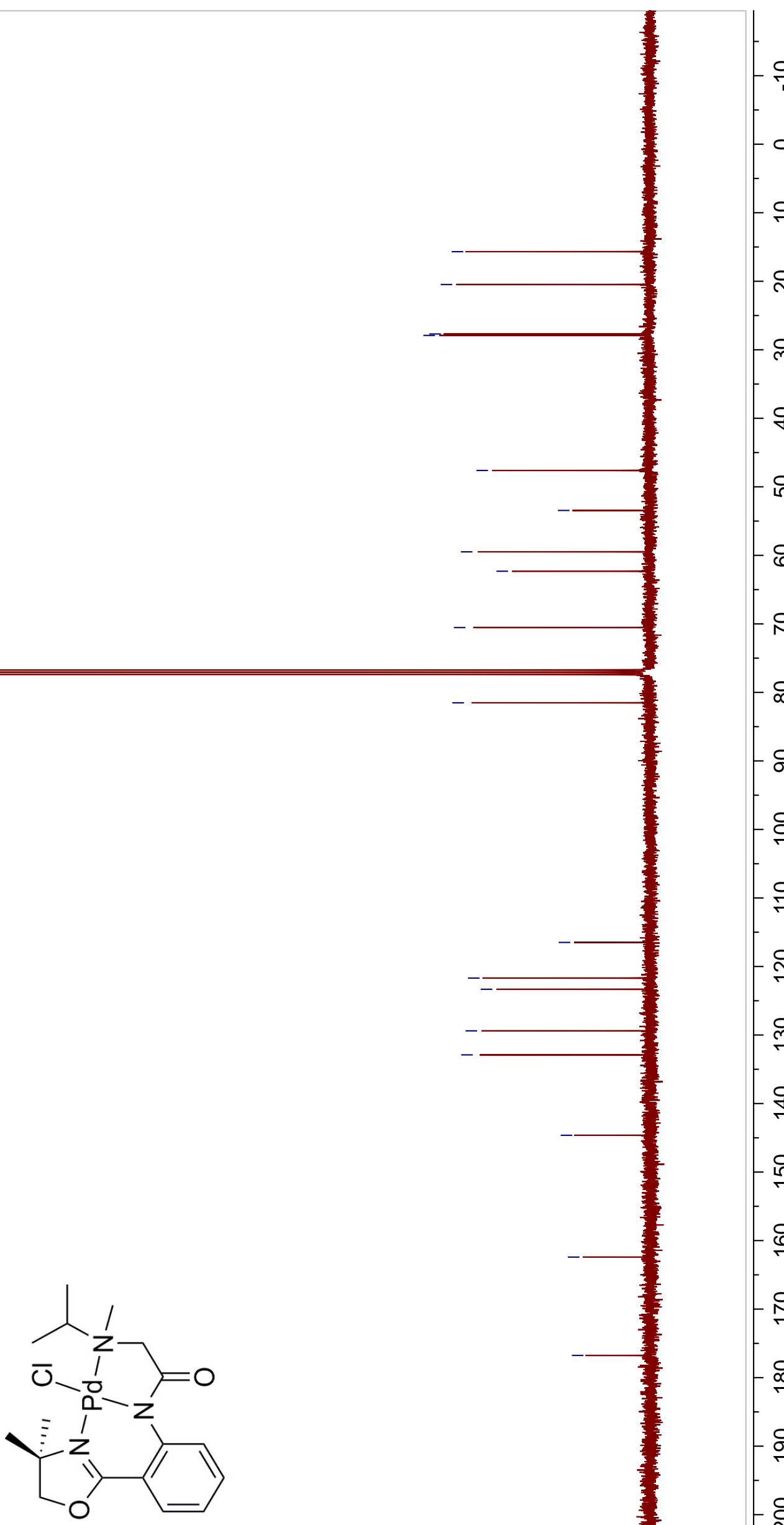

$-\frac{0}{1}$

○

으

인

ㅇ

우

요

8

옹

$\infty$

8

으응

을

$\stackrel{ }{ }$

오

움

옴

움

욷

$\infty$

음

-

\&

은

익 


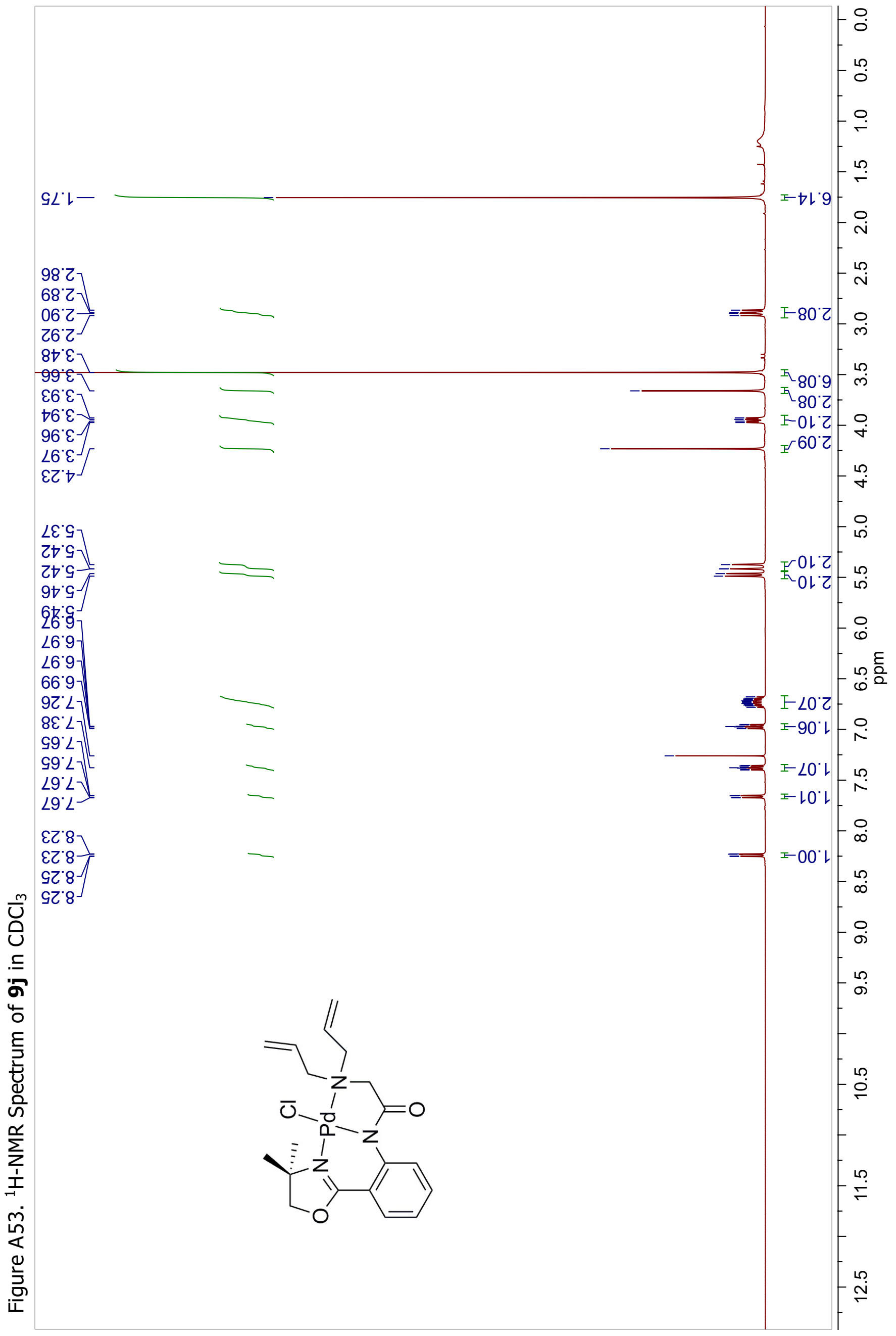




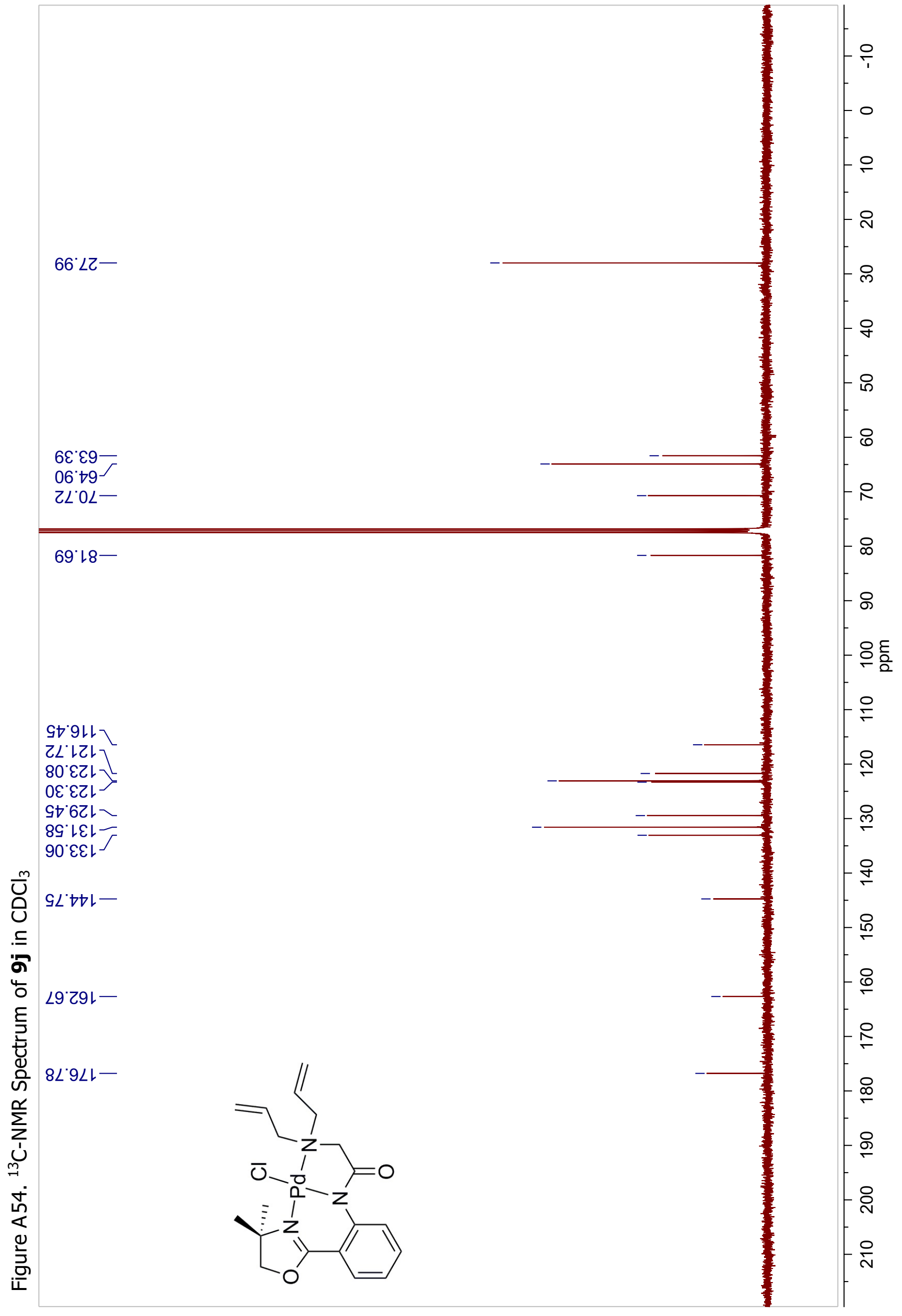




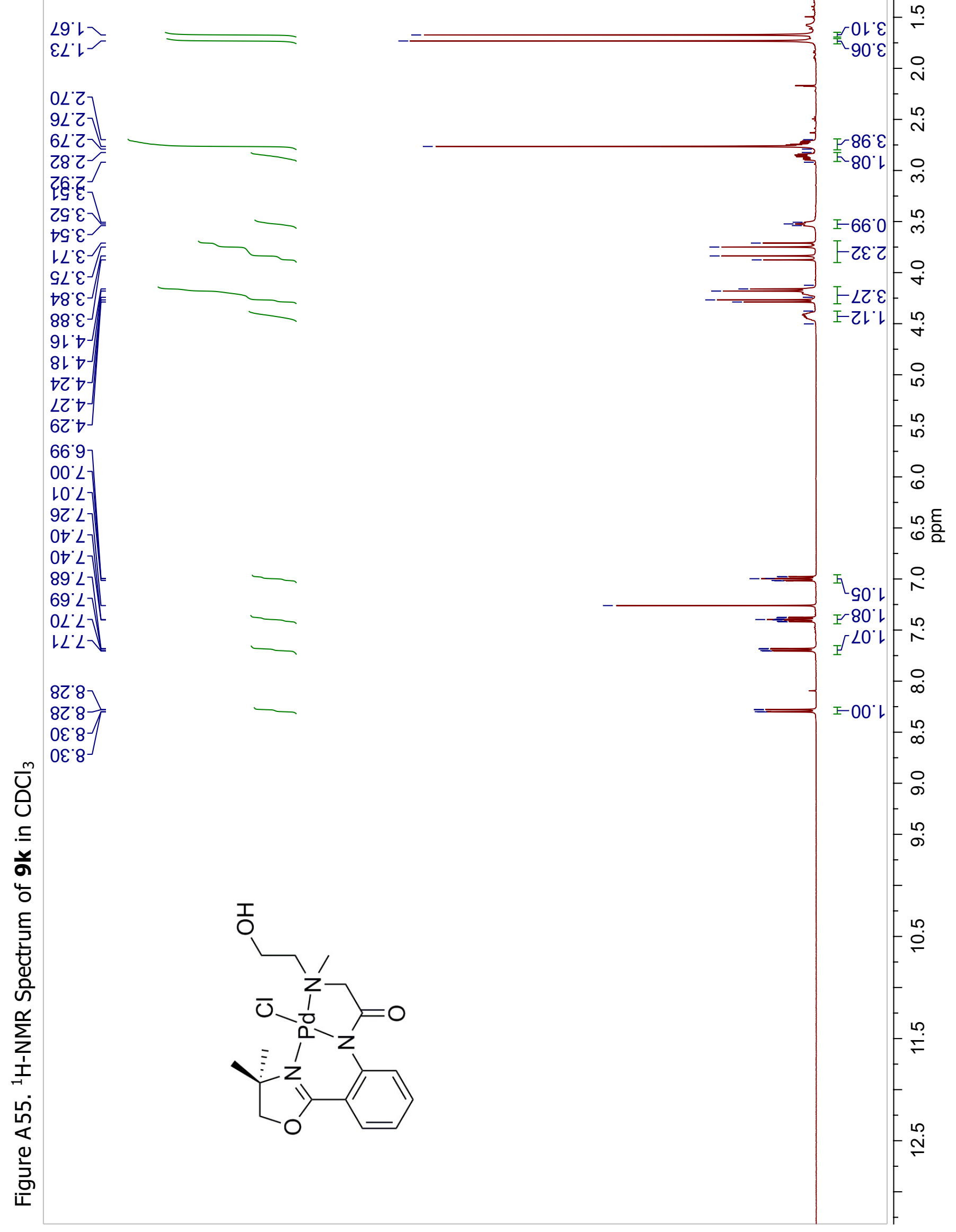


$79^{\circ} L Z \succ$

$88^{\circ} \angle Z^{J}$

98.09-

乙乙.09-

हl's9

$020<7$

$6+02$

$97 \div 8-$

เカ9レー

96.レて二

99.6ZL -

$\angle 0^{\circ} \varepsilon \varepsilon L$

ডับ $9 \varepsilon^{\circ}$ เレー

न

顿 s9'291-
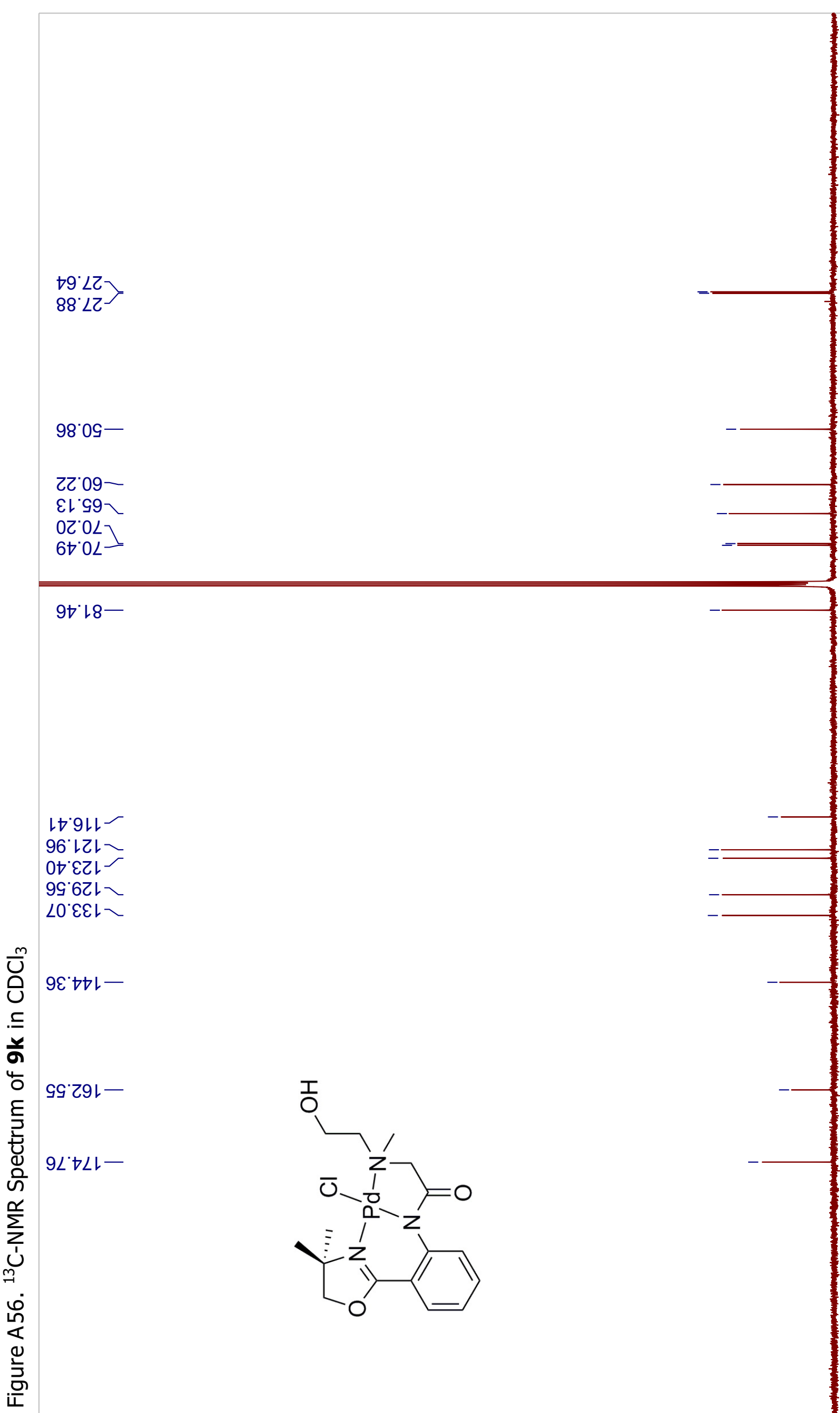

$-\frac{0}{1}$

-

으

ำ

요

우

우

8

ㅇ

$\infty$

8

으응ㅇ 을

읃

온

오

$\stackrel{ }{ }$

$\stackrel{\circ}{\circ}$

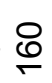

옹

$\stackrel{\infty}{\circ}$

옴

\&

은 
2LL二

$\varepsilon L^{\circ}$

sLt

sE'

$\angle E^{\circ} \nabla$

$\angle \forall \nabla^{-}$

$9 t^{\circ} 9$

$0 S^{\circ} 9$

69 ' 9

E9 9

ZL' $\mathrm{S}$

$9 L 9$

L' 9

L'9 ᄀ

$10 \angle 7$

20.2

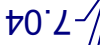

OL' $L$

$\Delta Z L^{\circ}$

St L

$99^{\circ} \mathrm{L}$

$89^{\circ} \mathrm{L}$

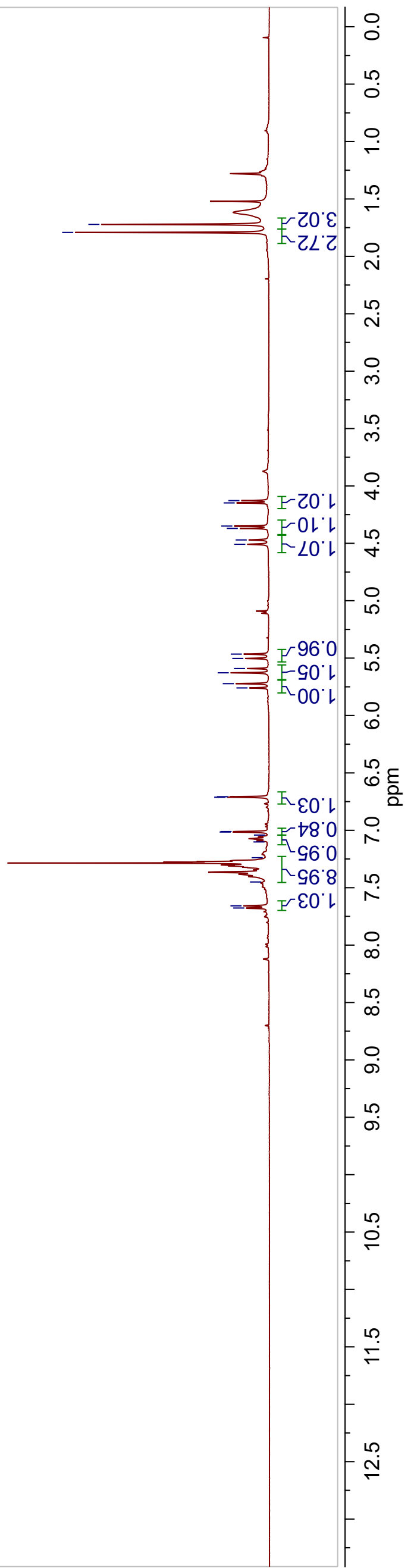




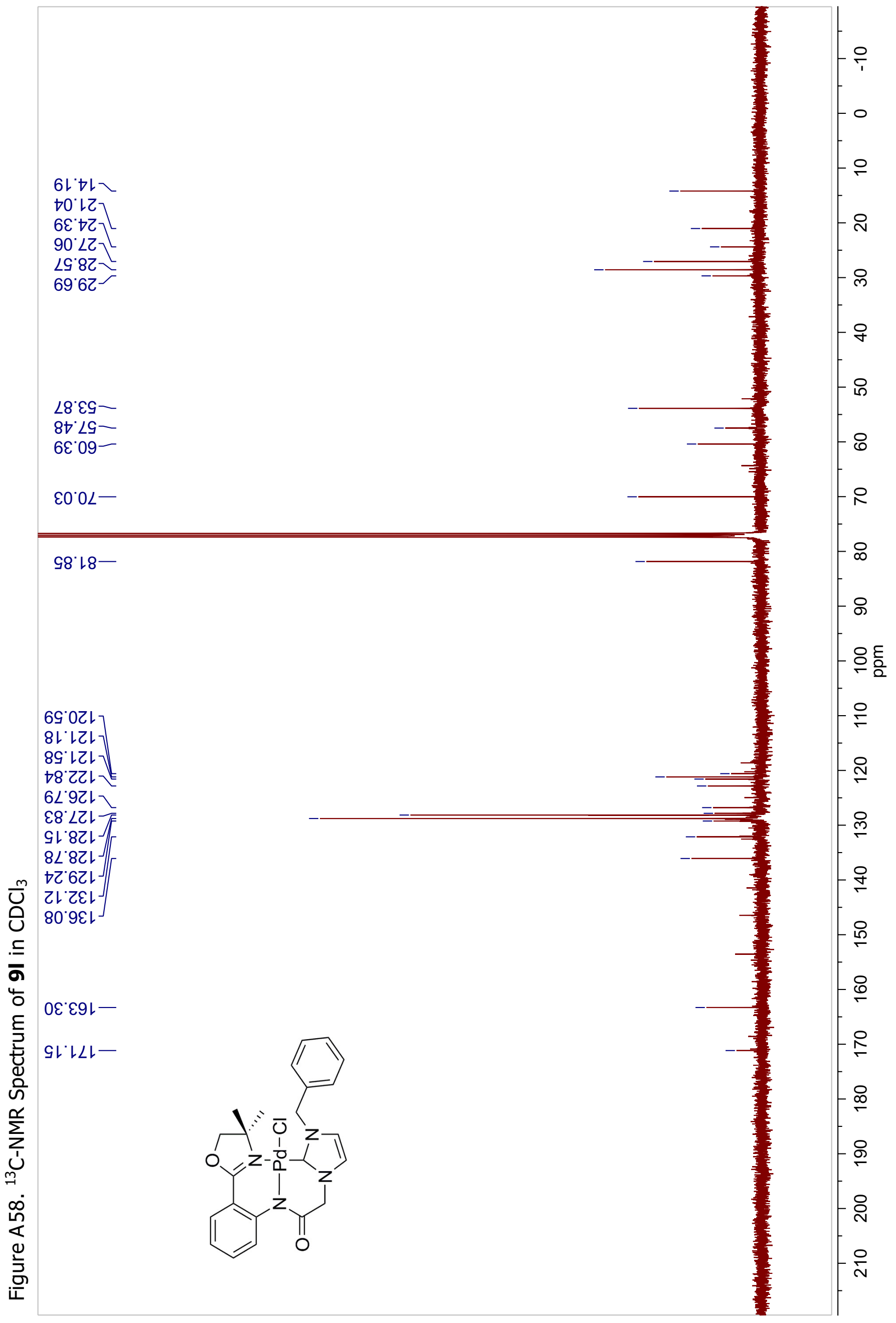


$99^{\circ}$ -

$8 L^{\circ} L$

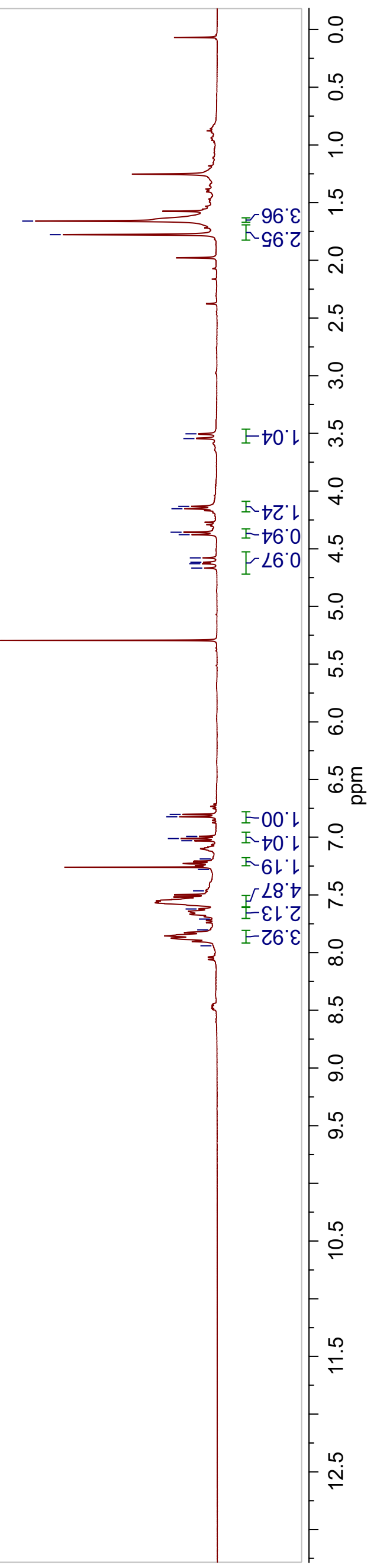

$09^{\circ} \varepsilon>$

$\nabla \mathcal{G}^{\circ} \mathcal{E}^{-}$

$\varepsilon L \cdot \nabla]$

$9 \varepsilon \cdot \nabla>$

89' $\nabla-\bar{F}$

$\varepsilon 9^{\circ} \nabla$

$\angle 9^{\circ} \nabla^{\circ}$

$08^{\circ} 9$

ट०' 9

$66^{\circ} 9$

$\left.66^{\circ} 9\right]$

$10^{\circ} \mathrm{L}$

$80{ }^{\circ}$

$6 L^{\circ} \mathrm{L}$

$8 \mathrm{C}^{\circ} \mathrm{L}$

9t' $L$

$29^{\circ} L$

$L L L$

$08: 2$

76.2
อ

ติ

4

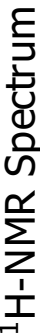

ํํㅇ

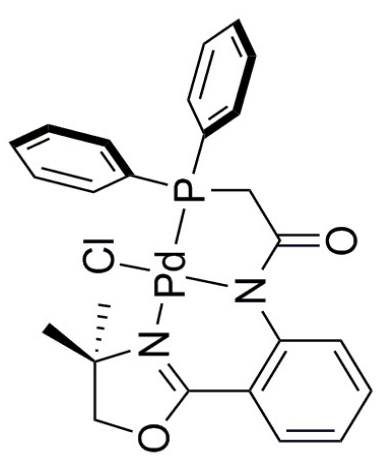




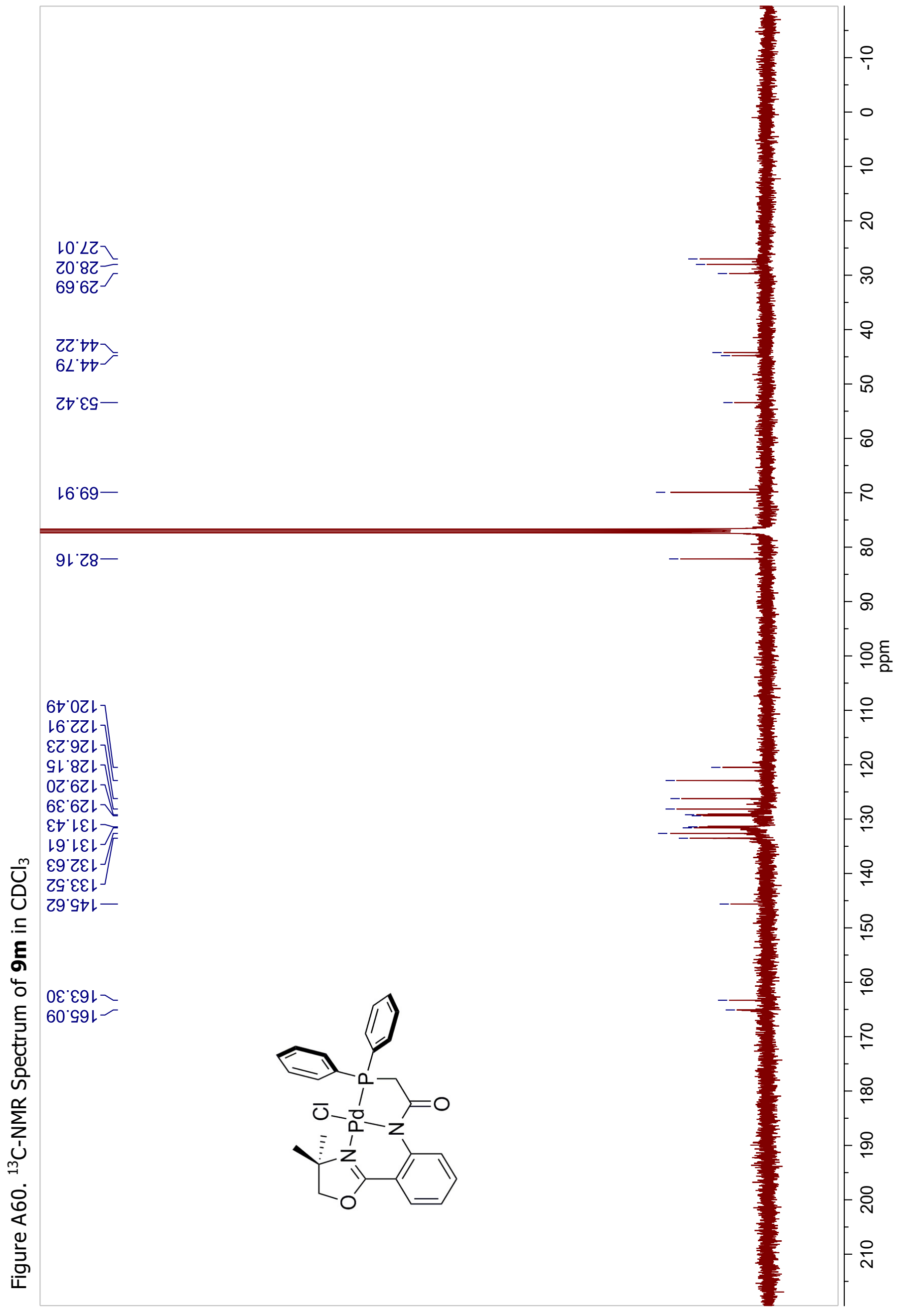



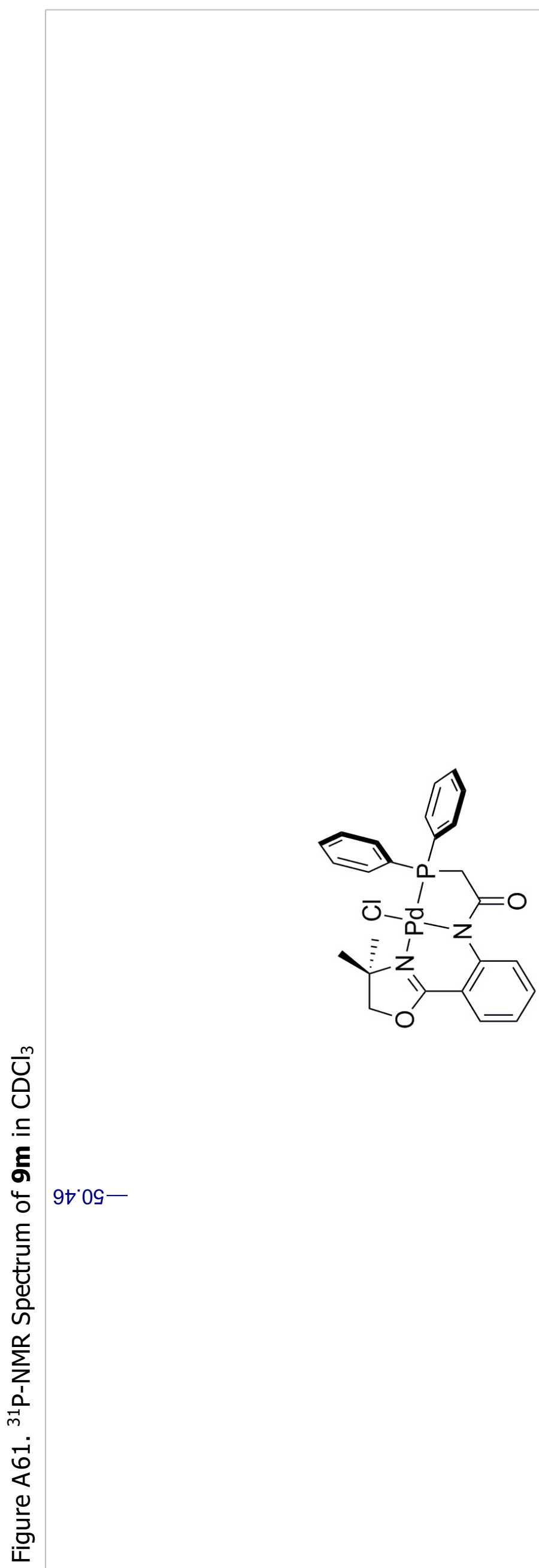


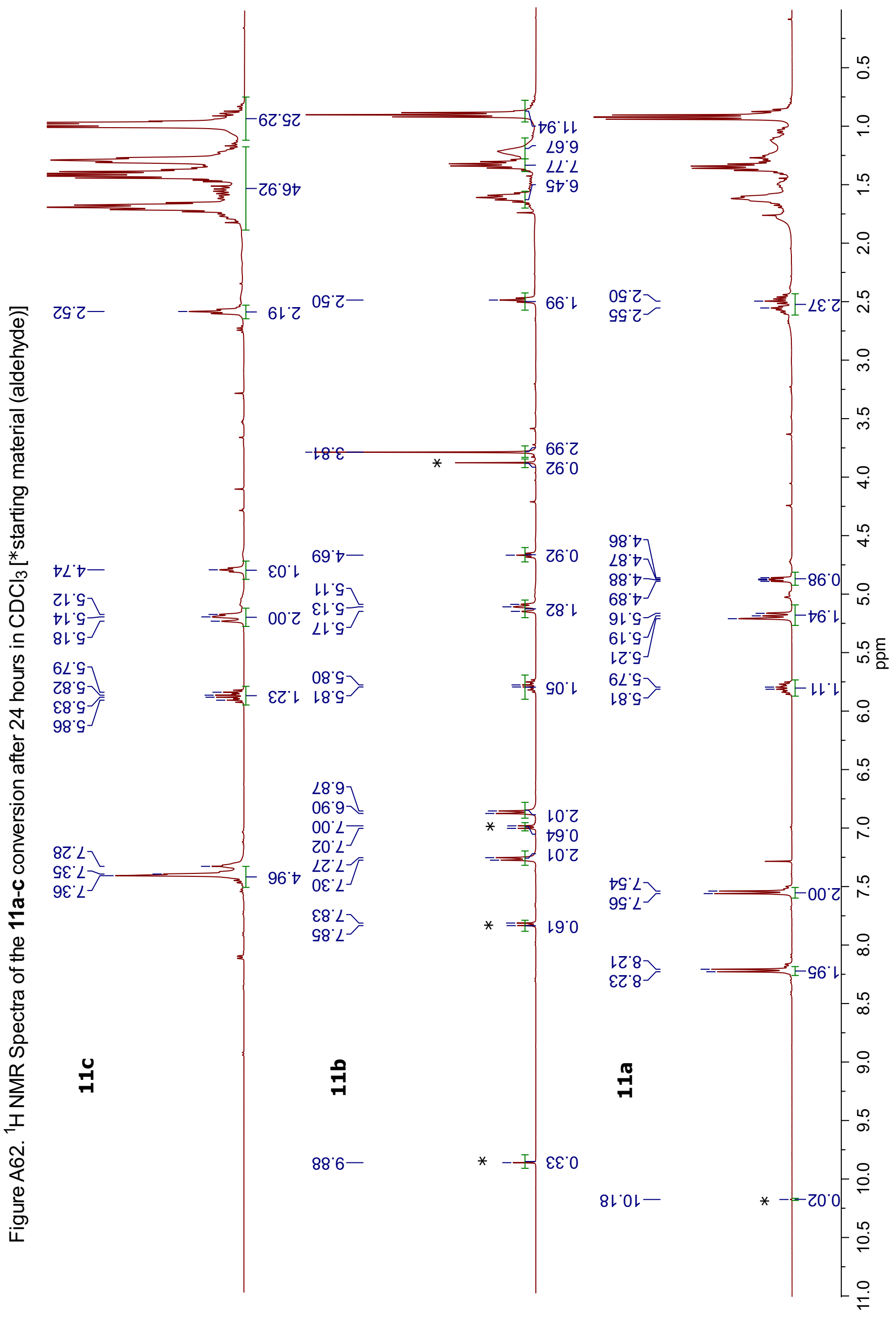




\subsection{X-RAY CRYSTALLOGRAPHY DATA}

Table A1. Crystal data and structure refinement for 2.

Table A2. Bond lengths $[\AA]$ and angles $\left[{ }^{\circ}\right]$ for 2.

Table A3. Torsion angles $\left[^{\circ}\right]$ for 2

Table A4. Hydrogen bonds for $2\left[\AA\right.$ and $\left.{ }^{\circ}\right]$.

Table A5. Bond lengths $[\AA]$ for $3 \mathrm{~m} \bullet$ oxide

Table A6. Angles $\left[{ }^{\circ}\right]$ for $\mathbf{3 m} \cdot$ oxide

Table A7. Torsion angles $\left[{ }^{\circ}\right]$ for $3 \mathrm{~m} \bullet$ oxide

Table A8. Bond lengths $[\AA]$ for 6

Table A9. Angles $\left[{ }^{\circ}\right]$ for 6

Table A10. Torsion angles [ $\left.{ }^{\circ}\right]$ for 6

Table A11. Bond lengths $[\AA]$ for $9 a$

Table A12. Angles $\left[^{\circ}\right]$ for $9 a$

Table A13. Torsion angles $\left[{ }^{\circ}\right]$ for $9 a$

Crystallographic data for $9 \mathrm{~h}$ is pending. 
Table A1. Crystal data and structure refinement for 2.

Empirical formula

Formula weight

Temperature

Wavelength

Crystal system

Space group

Unit cell dimensions

Volume

Z

Density (calculated)

Absorption coefficient

$\mathrm{F}(000)$

Crystal size

Theta range for data collection

Index ranges

Reflections collected

Independent reflections

Completeness to theta $=25.24^{\circ}$

Absorption correction

Max. and min. transmission

Refinement method

Data / restraints / parameters

Goodness-of-fit on F2

Final $R$ indices [l>2sigma(I)]

$\mathrm{R}$ indices (all data)

Largest diff. peak and hole
$\mathrm{C} 13 \mathrm{H} 15 \mathrm{Cl}$ N2 O2

266.72

150(1) K

$0.71073 \AA$

Triclinic

$\mathrm{P}-1$

$a=8.3982(12) \AA \quad a=80.500(3)^{\circ}$.

$b=8.9541(12) \AA \quad b=72.754(3)^{\circ}$.

$c=9.4632(13) \AA \quad g=71.727(3)^{\circ}$.

643.31(15) $\AA^{3}$

2

$1.377 \mathrm{Mg} / \mathrm{m}^{3}$

$0.293 \mathrm{~mm}^{-1}$

280

$0.28 \times 0.21 \times 0.15 \mathrm{~mm}^{3}$

2.26 to $26.03^{\circ}$.

$-10<=\mathrm{h}<=10,-11<=\mathrm{k}<=10,-11<=\mathrm{k}<=5$

4099

$2464[R($ int $)=0.0190]$

$97.6 \%$

Semi-empirical from equivalents

0.9574 and 0.9226

Full-matrix least-squares on $\mathrm{F}^{2}$

2464 / 0 / 169

1.035

$\mathrm{R} 1=0.0368, \mathrm{wR} 2=0.0895$

$\mathrm{R} 1=0.0456, \mathrm{wR} 2=0.0955$

0.261 and -0.288 e. $\AA^{-}-3$ 
Table A2. Bond lengths $[\AA]$ and angles $\left[^{\circ}\right]$ for 2.

\begin{tabular}{ll}
\hline $\mathrm{Cl}(1)-\mathrm{C}(13)$ & $1.7828(17)$ \\
$\mathrm{O}(1)-\mathrm{C}(7)$ & $1.3667(19)$ \\
$\mathrm{O}(1)-\mathrm{C}(8)$ & $1.4539(19)$ \\
$\mathrm{O}(2)-\mathrm{C}(12)$ & $1.218(2)$ \\
$\mathrm{N}(1)-\mathrm{C}(12)$ & $1.357(2)$ \\
$\mathrm{N}(1)-\mathrm{C}(1)$ & $1.407(2)$ \\
$\mathrm{N}(1)-\mathrm{H}(1 \mathrm{~N})$ & $0.853(19)$ \\
$\mathrm{N}(2)-\mathrm{C}(7)$ & $1.268(2)$ \\
$\mathrm{N}(2)-\mathrm{C}(9)$ & $1.489(2)$ \\
$\mathrm{C}(1)-\mathrm{C}(2)$ & $1.397(2)$ \\
$\mathrm{C}(1)-\mathrm{C}(6)$ & $1.415(2)$ \\
$\mathrm{C}(2)-\mathrm{C}(3)$ & $1.385(3)$ \\
$\mathrm{C}(2)-\mathrm{H}(2 \mathrm{~A})$ & 0.9500 \\
$\mathrm{C}(3)-\mathrm{C}(4)$ & $1.383(3)$ \\
$\mathrm{C}(3)-\mathrm{H}(3 A)$ & 0.9500 \\
$\mathrm{C}(4)-\mathrm{C}(5)$ & $1.380(2)$ \\
$\mathrm{C}(4)-\mathrm{H}(4 \mathrm{~A})$ & 0.9500 \\
$\mathrm{C}(5)-\mathrm{C}(6)$ & $1.393(2)$ \\
$\mathrm{C}(5)-\mathrm{H}(5 \mathrm{~A})$ & 0.9500 \\
$\mathrm{C}(6)-\mathrm{C}(7)$ & $1.472(2)$ \\
$\mathrm{C}(8)-\mathrm{C}(9)$ & $1.541(2)$ \\
$\mathrm{C}(8)-\mathrm{H}(8 \mathrm{~A})$ & 0.9900 \\
$\mathrm{C}(8)-\mathrm{H}(8 \mathrm{~B})$ & 0.9900 \\
$\mathrm{C}(9)-\mathrm{C}(11)$ & $1.516(3)$ \\
$\mathrm{C}(9)-\mathrm{C}(10)$ & $1.518(3)$ \\
$\mathrm{C}(10)-\mathrm{H}(10 \mathrm{~A})$ & 0.9800 \\
$\mathrm{C}(10)-\mathrm{H}(10 \mathrm{~B})$ & 0.9800 \\
$\mathrm{C}(10)-\mathrm{H}(10 \mathrm{C})$ & 0.9800 \\
$\mathrm{C}(11)-\mathrm{H}(11 \mathrm{~A})$ & 0.9800 \\
$\mathrm{C}(11)-\mathrm{H}(11 \mathrm{~B})$ & 0.9800 \\
$\mathrm{C}(11)-\mathrm{H}(11 \mathrm{C})$ & 0.9800 \\
$\mathrm{C}(12)-\mathrm{C}(13)$ & $1.510(2)$ \\
$\mathrm{C}(13)-\mathrm{H}(13 \mathrm{~B})$ & 0.9900 \\
$\mathrm{C}(13)-\mathrm{H}(13 \mathrm{~A})$ & 0.9900 \\
\end{tabular}




$\begin{array}{ll}\mathrm{C}(7)-\mathrm{O}(1)-\mathrm{C}(8) & 104.67(12) \\ \mathrm{C}(12)-\mathrm{N}(1)-\mathrm{C}(1) & 127.77(14) \\ \mathrm{C}(12)-\mathrm{N}(1)-\mathrm{H}(1 \mathrm{~N}) & 116.4(13) \\ \mathrm{C}(1)-\mathrm{N}(1)-\mathrm{H}(1 \mathrm{~N}) & 115.7(13) \\ \mathrm{C}(7)-\mathrm{N}(2)-\mathrm{C}(9) & 107.79(13) \\ \mathrm{C}(2)-\mathrm{C}(1)-\mathrm{N}(1) & 122.62(15) \\ \mathrm{C}(2)-\mathrm{C}(1)-\mathrm{C}(6) & 118.52(16) \\ \mathrm{N}(1)-\mathrm{C}(1)-\mathrm{C}(6) & 118.86(14) \\ \mathrm{C}(3)-\mathrm{C}(2)-\mathrm{C}(1) & 120.66(16) \\ \mathrm{C}(3)-\mathrm{C}(2)-\mathrm{H}(2 \mathrm{~A}) & 119.7 \\ \mathrm{C}(1)-\mathrm{C}(2)-\mathrm{H}(2 \mathrm{~A}) & 119.7 \\ \mathrm{C}(4)-\mathrm{C}(3)-\mathrm{C}(2) & 120.81(16) \\ \mathrm{C}(4)-\mathrm{C}(3)-\mathrm{H}(3 \mathrm{~A}) & 119.6 \\ \mathrm{C}(2)-\mathrm{C}(3)-\mathrm{H}(3 \mathrm{~A}) & 119.6 \\ \mathrm{C}(5)-\mathrm{C}(4)-\mathrm{C}(3) & 119.30(17) \\ \mathrm{C}(5)-\mathrm{C}(4)-\mathrm{H}(4 \mathrm{~A}) & 120.4 \\ \mathrm{C}(3)-\mathrm{C}(4)-\mathrm{H}(4 \mathrm{~A}) & 120.4 \\ \mathrm{C}(4)-\mathrm{C}(5)-\mathrm{C}(6) & 121.21(16) \\ \mathrm{C}(4)-\mathrm{C}(5)-\mathrm{H}(5 \mathrm{~A}) & 119.4 \\ \mathrm{C}(6)-\mathrm{C}(5)-\mathrm{H}(5 \mathrm{~A}) & 119.4 \\ \mathrm{C}(5)-\mathrm{C}(6)-\mathrm{C}(1) & 119.49(15) \\ \mathrm{C}(5)-\mathrm{C}(6)-\mathrm{C}(7) & 118.88(14) \\ \mathrm{C}(1)-\mathrm{C}(6)-\mathrm{C}(7) & 121.55(15) \\ \mathrm{N}(2)-\mathrm{C}(7)-\mathrm{O}(1) & 117.67(14) \\ \mathrm{N}(2)-\mathrm{C}(7)-\mathrm{C}(6) & 126.94(14) \\ \mathrm{O}(1)-\mathrm{C}(7)-\mathrm{C}(6) & 115.31(14) \\ \mathrm{O}(1)-\mathrm{C}(8)-\mathrm{C}(9) & 104.49(13) \\ \mathrm{O}(1)-\mathrm{C}(8)-\mathrm{H}(8 \mathrm{~A}) & 110.9 \\ \mathrm{C}(9)-\mathrm{C}(8)-\mathrm{H}(8 \mathrm{~A}) & 110.9 \\ \mathrm{O}(1)-\mathrm{C}(8)-\mathrm{H}(8 \mathrm{~B}) & 110.9 \\ \mathrm{C}(9)-\mathrm{C}(8)-\mathrm{H}(8 \mathrm{~B}) & 110.9 \\ \mathrm{H}(8 \mathrm{~A})-\mathrm{C}(8)-\mathrm{H}(8 \mathrm{~B}) & 108.9 \\ \mathrm{~N}(2)-\mathrm{C}(9)-\mathrm{C}(11) & 111.07(14) \\ \mathrm{N}(2)-\mathrm{C}(9)-\mathrm{C}(10) & 108.01(14) \\ \mathrm{C}(11)-\mathrm{C}(9)-\mathrm{C}(10) & 111.29(16) \\ \mathrm{N}(2)-\mathrm{C}(9)-\mathrm{C}(8) & 101.67(13) \\ & \end{array}$




\begin{tabular}{ll}
$\mathrm{C}(11)-\mathrm{C}(9)-\mathrm{C}(8)$ & $112.84(16)$ \\
$\mathrm{C}(10)-\mathrm{C}(9)-\mathrm{C}(8)$ & $111.49(15)$ \\
$\mathrm{C}(9)-\mathrm{C}(10)-\mathrm{H}(10 \mathrm{~A})$ & 109.5 \\
$\mathrm{C}(9)-\mathrm{C}(10)-\mathrm{H}(10 \mathrm{~B})$ & 109.5 \\
$\mathrm{H}(10 \mathrm{~A})-\mathrm{C}(10)-\mathrm{H}(10 \mathrm{~B})$ & 109.5 \\
$\mathrm{C}(9)-\mathrm{C}(10)-\mathrm{H}(10 \mathrm{C})$ & 109.5 \\
$\mathrm{H}(10 \mathrm{~A})-\mathrm{C}(10)-\mathrm{H}(10 \mathrm{C})$ & 109.5 \\
$\mathrm{H}(10 \mathrm{~B})-\mathrm{C}(10)-\mathrm{H}(10 \mathrm{C})$ & 109.5 \\
$\mathrm{C}(9)-\mathrm{C}(11)-\mathrm{H}(11 \mathrm{~A})$ & 109.5 \\
$\mathrm{C}(9)-\mathrm{C}(11)-\mathrm{H}(11 \mathrm{~B})$ & 109.5 \\
$\mathrm{H}(11 \mathrm{~A})-\mathrm{C}(11)-\mathrm{H}(11 \mathrm{~B})$ & 109.5 \\
$\mathrm{C}(9)-\mathrm{C}(11)-\mathrm{H}(11 \mathrm{C})$ & 109.5 \\
$\mathrm{H}(11 \mathrm{~A})-\mathrm{C}(11)-\mathrm{H}(11 \mathrm{C})$ & 109.5 \\
$\mathrm{H}(11 \mathrm{~B})-\mathrm{C}(11)-\mathrm{H}(11 \mathrm{C})$ & 109.5 \\
$\mathrm{O}(2)-\mathrm{C}(12)-\mathrm{N}(1)$ & $125.94(17)$ \\
$\mathrm{O}(2)-\mathrm{C}(12)-\mathrm{C}(13)$ & $116.52(15)$ \\
$\mathrm{N}(1)-\mathrm{C}(12)-\mathrm{C}(13)$ & $117.54(14)$ \\
$\mathrm{C}(12)-\mathrm{C}(13)-\mathrm{Cl}(1)$ & $117.10(12)$ \\
$\mathrm{C}(12)-\mathrm{C}(13)-\mathrm{H}(13 \mathrm{~B})$ & 108.0 \\
$\mathrm{Cl}(1)-\mathrm{C}(13)-\mathrm{H}(13 \mathrm{~B})$ & 108.0 \\
$\mathrm{C}(12)-\mathrm{C}(13)-\mathrm{H}(13 \mathrm{~A})$ & 108.0 \\
$\mathrm{Cl}(1)-\mathrm{C}(13)-\mathrm{H}(13 \mathrm{~A})$ & 108.0 \\
$\mathrm{H}(13 \mathrm{~B})-\mathrm{C}(13)-\mathrm{H}(13 \mathrm{~A})$ & 107.3 \\
\hline
\end{tabular}

Table A3. Torsion angles $\left[^{\circ}\right]$ for 2

\begin{tabular}{lc}
\hline$C(12)-N(1)-C(1)-C(2)$ & $-3.5(3)$ \\
$C(12)-N(1)-C(1)-C(6)$ & $176.50(16)$ \\
$N(1)-C(1)-C(2)-C(3)$ & $179.30(17)$ \\
$C(6)-C(1)-C(2)-C(3)$ & $-0.7(3)$ \\
$C(1)-C(2)-C(3)-C(4)$ & $-0.6(3)$ \\
$C(2)-C(3)-C(4)-C(5)$ & $0.9(3)$ \\
$C(3)-C(4)-C(5)-C(6)$ & $0.0(3)$ \\
$C(4)-C(5)-C(6)-C(1)$ & $-1.3(2)$
\end{tabular}




$\begin{array}{lc}\mathrm{C}(4)-\mathrm{C}(5)-\mathrm{C}(6)-\mathrm{C}(7) & 175.61(15) \\ \mathrm{C}(2)-\mathrm{C}(1)-\mathrm{C}(6)-\mathrm{C}(5) & 1.6(2) \\ \mathrm{N}(1)-\mathrm{C}(1)-\mathrm{C}(6)-\mathrm{C}(5) & -178.42(15) \\ \mathrm{C}(2)-\mathrm{C}(1)-\mathrm{C}(6)-\mathrm{C}(7) & -175.18(15) \\ \mathrm{N}(1)-\mathrm{C}(1)-\mathrm{C}(6)-\mathrm{C}(7) & 4.8(2) \\ \mathrm{C}(9)-\mathrm{N}(2)-\mathrm{C}(7)-\mathrm{O}(1) & -3.8(2) \\ \mathrm{C}(9)-\mathrm{N}(2)-\mathrm{C}(7)-\mathrm{C}(6) & 172.90(15) \\ \mathrm{C}(8)-\mathrm{O}(1)-\mathrm{C}(7)-\mathrm{N}(2) & -9.1(2) \\ \mathrm{C}(8)-\mathrm{O}(1)-\mathrm{C}(7)-\mathrm{C}(6) & 173.84(14) \\ \mathrm{C}(5)-\mathrm{C}(6)-\mathrm{C}(7)-\mathrm{N}(2) & -161.25(17) \\ \mathrm{C}(1)-\mathrm{C}(6)-\mathrm{C}(7)-\mathrm{N}(2) & 15.6(3) \\ \mathrm{C}(5)-\mathrm{C}(6)-\mathrm{C}(7)-\mathrm{O}(1) & 15.5(2) \\ \mathrm{C}(1)-\mathrm{C}(6)-\mathrm{C}(7)-\mathrm{O}(1) & -167.67(15) \\ \mathrm{C}(7)-\mathrm{O}(1)-\mathrm{C}(8)-\mathrm{C}(9) & 17.04(17) \\ \mathrm{C}(7)-\mathrm{N}(2)-\mathrm{C}(9)-\mathrm{C}(11) & 134.32(17) \\ \mathrm{C}(7)-\mathrm{N}(2)-\mathrm{C}(9)-\mathrm{C}(10) & -103.38(17) \\ \mathrm{C}(7)-\mathrm{N}(2)-\mathrm{C}(9)-\mathrm{C}(8) & 14.04(18) \\ \mathrm{O}(1)-\mathrm{C}(8)-\mathrm{C}(9)-\mathrm{N}(2) & -18.69(17) \\ \mathrm{O}(1)-\mathrm{C}(8)-\mathrm{C}(9)-\mathrm{C}(11) & -137.72(15) \\ \mathrm{O}(1)-\mathrm{C}(8)-\mathrm{C}(9)-\mathrm{C}(10) & 96.18(16) \\ \mathrm{C}(1)-\mathrm{N}(1)-\mathrm{C}(12)-\mathrm{O}(2) & -2.8(3) \\ \mathrm{C}(1)-\mathrm{N}(1)-\mathrm{C}(12)-\mathrm{C}(13) & 177.11(15) \\ \mathrm{O}(2)-\mathrm{C}(12)-\mathrm{C}(13)-\mathrm{Cl}(1) & -178.63(13) \\ \mathrm{N}(1)-\mathrm{C}(12)-\mathrm{C}(13)-\mathrm{Cl}(1) & 1.5(2) \\ & \end{array}$

Table A4. Hydrogen bonds for 2 [A and $\left.{ }^{\circ}\right]$.

\begin{tabular}{lcccc}
\hline $\mathrm{D}-\mathrm{H} \ldots \mathrm{A}$ & $\mathrm{d}(\mathrm{D}-\mathrm{H})$ & $\mathrm{d}(\mathrm{H} \ldots \mathrm{A})$ & $\mathrm{d}(\mathrm{D} \ldots \mathrm{A})$ & $<(\mathrm{DHA})$ \\
\hline $\mathrm{N}(1)-\mathrm{H}(1 \mathrm{~N}) \ldots \mathrm{N}(2)$ & $0.853(19)$ & $2.03(2)$ & $2.732(2)$ & $138.9(17)$ \\
$\mathrm{N}(1)-\mathrm{H}(1 \mathrm{~N}) \ldots \mathrm{Cl}(1)$ & $0.853(19)$ & $2.468(19)$ & $2.9746(15)$ & $118.9(16)$ \\
\hline
\end{tabular}


Table A5. Bond lengths $[\AA]$ for $3 \mathrm{~m} \bullet$ oxide

\begin{tabular}{|c|c|c|}
\hline C1 & $\mathrm{H} 1 \mathrm{~A}$ & $0.970(2)$ \\
\hline C1 & H1B & $0.971(1)$ \\
\hline C1 & $\mathrm{C} 2$ & $1.517(2)$ \\
\hline C1 & P1 & $1.816(2)$ \\
\hline $\mathrm{C} 2$ & N1 & $1.351(2)$ \\
\hline $\mathrm{C} 2$ & $\mathrm{O} 2$ & $1.227(2)$ \\
\hline C3 & C4 & $1.398(3)$ \\
\hline C3 & C8 & $1.409(2)$ \\
\hline C3 & N1 & $1.405(2)$ \\
\hline C4 & $\mathrm{H} 4$ & $0.930(2)$ \\
\hline C4 & C5 & $1.384(3)$ \\
\hline C5 & H5 & $0.930(2)$ \\
\hline C5 & C6 & $1.384(3)$ \\
\hline C6 & $\mathrm{H} 6$ & $0.930(2)$ \\
\hline C6 & C7 & $1.382(3)$ \\
\hline $\mathrm{C} 7$ & $\mathrm{H} 7$ & $0.931(2)$ \\
\hline $\mathrm{C} 7$ & C8 & $1.393(3)$ \\
\hline $\mathrm{C} 8$ & $\mathrm{C9}$ & $1.472(3)$ \\
\hline C9 & N2 & $1.256(3)$ \\
\hline C9 & $\mathrm{O} 3$ & $1.324(4)$ \\
\hline C10 & $\mathrm{H} 10 \mathrm{~A}$ & $0.970(3)$ \\
\hline C10 & $\mathrm{H} 10 \mathrm{~B}$ & $0.970(4)$ \\
\hline C10 & C11 & $1.532(5)$ \\
\hline C10 & $\mathrm{O} 3$ & $1.450(5)$ \\
\hline C11 & C12 & $1.498(4)$ \\
\hline C11 & $\mathrm{C} 13$ & $1.504(3)$ \\
\hline C11 & N2 & $1.471(3)$ \\
\hline C12 & $\mathrm{H} 12 \mathrm{~A}$ & $0.959(3)$ \\
\hline C12 & H12B & $0.960(4)$ \\
\hline $\mathrm{C} 12$ & $\mathrm{H} 12 \mathrm{C}$ & $0.960(3)$ \\
\hline $\mathrm{C} 13$ & $\mathrm{H} 13 \mathrm{~A}$ & $0.960(3)$ \\
\hline $\mathrm{C} 13$ & $\mathrm{H} 13 \mathrm{~B}$ & $0.960(3)$ \\
\hline $\mathrm{C} 13$ & $\mathrm{H} 13 \mathrm{C}$ & $0.961(3)$ \\
\hline $\mathrm{C} 20$ & C21 & $1.396(2)$ \\
\hline $\mathrm{C} 20$ & C25 & $1.397(2)$ \\
\hline $\mathrm{C} 20$ & P1 & $1.804(2)$ \\
\hline C21 & $\mathrm{H} 21$ & $0.930(1)$ \\
\hline C21 & $\mathrm{C} 22$ & $1.387(3)$ \\
\hline $\mathrm{C} 22$ & $\mathrm{H} 22$ & $0.930(2)$ \\
\hline $\mathrm{C} 22$ & $\mathrm{C} 23$ & $1.384(2)$ \\
\hline $\mathrm{C} 23$ & $\mathrm{H} 23$ & $0.930(2)$ \\
\hline
\end{tabular}




\begin{tabular}{|c|c|c|}
\hline $\mathrm{C} 23$ & $\mathrm{C} 24$ & $1.386(3)$ \\
\hline C24 & $\mathrm{H} 24$ & $0.930(1)$ \\
\hline C24 & $\mathrm{C} 25$ & $1.387(3)$ \\
\hline C25 & $\mathrm{H} 25$ & $0.930(2)$ \\
\hline C30 & C31 & $1.393(2)$ \\
\hline C30 & C35 & $1.396(2)$ \\
\hline C30 & $\mathrm{P} 1$ & $1.803(2)$ \\
\hline C31 & $\mathrm{H} 31$ & $0.930(2)$ \\
\hline C31 & C32 & $1.387(3)$ \\
\hline C32 & H32 & $0.930(2)$ \\
\hline C32 & C33 & $1.383(2)$ \\
\hline C33 & H33 & $0.930(2)$ \\
\hline C33 & C34 & $1.388(2)$ \\
\hline C34 & $\mathrm{H} 34$ & $0.930(2)$ \\
\hline C34 & C35 & $1.383(3)$ \\
\hline C35 & H35 & $0.930(2)$ \\
\hline N1 & $\mathrm{H} 1$ & $0.87(2)$ \\
\hline 01 & P1 & $1.489(1)$ \\
\hline O40 & $\mathrm{H} 40 \mathrm{~A}$ & $0.91(2)$ \\
\hline O40 & $\mathrm{H} 40 \mathrm{~B}$ & $0.92(2)$ \\
\hline
\end{tabular}

Table A6. Angles [ $\left.{ }^{\circ}\right]$ for $3 \mathrm{~m} \cdot$ oxide

\begin{tabular}{llll}
\hline H1A & C1 & H1B & $107.9(2)$ \\
H1A & C1 & C2 & $109.1(1)$ \\
H1A & C1 & P1 & $109.1(1)$ \\
H1B & C1 & C2 & $109.1(1)$ \\
H1B & C1 & P1 & $109.1(1)$ \\
C2 & C1 & P1 & $112.5(1)$ \\
C1 & C2 & N1 & $113.7(1)$ \\
C1 & C2 & O2 & $121.2(1)$ \\
N1 & C2 & O2 & $125.1(1)$ \\
C4 & C3 & C8 & $119.2(1)$ \\
C4 & C3 & N1 & $123.5(1)$ \\
C8 & C3 & N1 & $117.3(1)$ \\
C3 & C4 & H4 & $119.9(2)$ \\
C3 & C4 & C5 & $120.3(2)$ \\
H4 & C4 & C5 & $119.8(2)$ \\
C4 & C5 & H5 & $119.7(2)$ \\
C4 & C5 & C6 & $120.5(2)$ \\
H5 & C5 & C6 & $119.8(2)$ \\
C5 & C6 & H6 & $120.1(2)$
\end{tabular}




$\begin{array}{llll}\mathrm{C} 5 & \mathrm{C} 6 & \mathrm{C} 7 & 119.8(2) \\ \mathrm{H} 6 & \mathrm{C} 6 & \mathrm{C} 7 & 120.1(2) \\ \mathrm{C} 6 & \mathrm{C} 7 & \mathrm{H} 7 & 119.5(2) \\ \mathrm{C} 6 & \mathrm{C} 7 & \mathrm{C} 8 & 120.9(2) \\ \mathrm{H} 7 & \mathrm{C} 7 & \mathrm{C} 8 & 119.6(2) \\ \mathrm{C} 3 & \mathrm{C} 8 & \mathrm{C} 7 & 119.3(2) \\ \mathrm{C} 3 & \mathrm{C} 8 & \mathrm{C} 9 & 121.9(2) \\ \mathrm{C} 7 & \mathrm{C} 8 & \mathrm{C} 9 & 118.7(2) \\ \mathrm{C} 8 & \mathrm{C} 9 & \mathrm{~N} 2 & 127.8(2) \\ \mathrm{C} 8 & \mathrm{C} 9 & \mathrm{O} 3 & 115.3(2) \\ \mathrm{N} 2 & \mathrm{C} 9 & \mathrm{O} 3 & 116.9(2) \\ \mathrm{H} 10 \mathrm{~A} & \mathrm{C} 10 & \mathrm{H} 10 \mathrm{~B} & 108.9(4) \\ \mathrm{H} 10 \mathrm{~A} & \mathrm{C} 10 & \mathrm{C} 11 & 110.9(3) \\ \mathrm{H} 10 \mathrm{~A} & \mathrm{C} 10 & \mathrm{O} 3 & 110.9(3) \\ \mathrm{H} 10 \mathrm{~B} & \mathrm{C} 10 & \mathrm{C} 11 & 110.9(3) \\ \mathrm{H} 10 \mathrm{~B} & \mathrm{C} 10 & \mathrm{O} 3 & 110.9(3) \\ \mathrm{C} 11 & \mathrm{C} 10 & \mathrm{O} 3 & 104.2(3) \\ \mathrm{C} 10 & \mathrm{C} 11 & \mathrm{C} 12 & 113.4(2) \\ \mathrm{C} 10 & \mathrm{C} 11 & \mathrm{C} 13 & 111.6(2) \\ \mathrm{C} 10 & \mathrm{C} 11 & \mathrm{~N} 2 & 102.2(2) \\ \mathrm{C} 12 & \mathrm{C} 11 & \mathrm{C} 13 & 110.2(2) \\ \mathrm{C} 12 & \mathrm{C} 11 & \mathrm{~N} 2 & 109.9(2) \\ \mathrm{C} 13 & \mathrm{C} 11 & \mathrm{~N} 2 & 109.2(2) \\ \mathrm{C} 11 & \mathrm{C} 12 & \mathrm{H} 12 \mathrm{~A} & 109.5(3) \\ \mathrm{C} 11 & \mathrm{C} 12 & \mathrm{H} 12 \mathrm{~B} & 109.4(3) \\ \mathrm{C} 11 & \mathrm{C} 12 & \mathrm{H} 12 \mathrm{C} & 109.5(3) \\ \mathrm{H} 12 \mathrm{~A} & \mathrm{C} 12 & \mathrm{H} 12 \mathrm{~B} & 109.5(3) \\ \mathrm{H} 12 \mathrm{~A} & \mathrm{C} 12 & \mathrm{H} 12 \mathrm{C} & 109.5(3) \\ \mathrm{H} 12 \mathrm{~B} & \mathrm{C} 12 & \mathrm{H} 12 \mathrm{C} & 109.5(3) \\ \mathrm{C} 11 & \mathrm{C} 13 & \mathrm{H} 13 \mathrm{~A} & 109.5(2) \\ \mathrm{C} 11 & \mathrm{C} 13 & \mathrm{H} 13 \mathrm{~B} & 109.5(2) \\ \mathrm{C} 11 & \mathrm{C} 13 & \mathrm{H} 13 \mathrm{C} & 109.4(2) \\ \mathrm{H} 13 \mathrm{~A} & \mathrm{C} 13 & \mathrm{H} 13 \mathrm{~B} & 109.5(3) \\ \mathrm{H} 13 \mathrm{~A} & \mathrm{C} 13 & \mathrm{H} 13 \mathrm{C} & 109.5(3) \\ \mathrm{H} 13 \mathrm{~B} & \mathrm{C} 13 & \mathrm{H} 13 \mathrm{C} & 109.4(3) \\ \mathrm{C} 21 & \mathrm{C} 20 & \mathrm{C} 25 & 119.3(1) \\ \mathrm{C} 21 & \mathrm{C} 20 & \mathrm{P} 1 & 117.7(1) \\ \mathrm{C} 25 & \mathrm{C} 20 & \mathrm{P} 1 & 122.9(1) \\ \mathrm{C} 20 & \mathrm{C} 21 & \mathrm{H} 21 & 119.9(2) \\ \mathrm{C} 20 & \mathrm{C} 21 & \mathrm{C} 22 & 120.1(2) \\ \mathrm{H} 21 & \mathrm{C} 21 & \mathrm{C} 22 & 120.0(2) \\ \mathrm{C} 21 & \mathrm{C} 22 & \mathrm{H} 22 & 119.9(2) \\ \mathrm{C} 21 & \mathrm{C} 22 & \mathrm{C} 23 & 120.2(2)\end{array}$




\begin{tabular}{llll}
$\mathrm{H} 22$ & $\mathrm{C} 22$ & $\mathrm{C} 23$ & $119.9(2)$ \\
$\mathrm{C} 22$ & $\mathrm{C} 23$ & $\mathrm{H} 23$ & $120.0(2)$ \\
$\mathrm{C} 22$ & $\mathrm{C} 23$ & $\mathrm{C} 24$ & $120.1(2)$ \\
$\mathrm{H} 23$ & $\mathrm{C} 23$ & $\mathrm{C} 24$ & $119.9(2)$ \\
$\mathrm{C} 23$ & $\mathrm{C} 24$ & $\mathrm{H} 24$ & $120.0(2)$ \\
$\mathrm{C} 23$ & $\mathrm{C} 24$ & $\mathrm{C} 25$ & $120.2(2)$ \\
$\mathrm{H} 24$ & $\mathrm{C} 24$ & $\mathrm{C} 25$ & $119.9(2)$ \\
$\mathrm{C} 20$ & $\mathrm{C} 25$ & $\mathrm{C} 24$ & $120.1(2)$ \\
$\mathrm{C} 20$ & $\mathrm{C} 25$ & $\mathrm{H} 25$ & $119.9(2)$ \\
$\mathrm{C} 24$ & $\mathrm{C} 25$ & $\mathrm{H} 25$ & $120.0(2)$ \\
$\mathrm{C} 31$ & $\mathrm{C} 30$ & $\mathrm{C} 35$ & $119.4(2)$ \\
$\mathrm{C} 31$ & $\mathrm{C} 30$ & $\mathrm{P} 1$ & $118.4(1)$ \\
$\mathrm{C} 35$ & $\mathrm{C} 30$ & $\mathrm{P} 1$ & $122.2(1)$ \\
$\mathrm{C} 30$ & $\mathrm{C} 31$ & $\mathrm{H} 31$ & $120.0(2)$ \\
$\mathrm{C} 30$ & $\mathrm{C} 31$ & $\mathrm{C} 32$ & $120.0(2)$ \\
$\mathrm{H} 31$ & $\mathrm{C} 31$ & $\mathrm{C} 32$ & $120.0(2)$ \\
$\mathrm{C} 31$ & $\mathrm{C} 32$ & $\mathrm{H} 32$ & $119.8(2)$ \\
$\mathrm{C} 31$ & $\mathrm{C} 32$ & $\mathrm{C} 33$ & $120.3(2)$ \\
$\mathrm{H} 32$ & $\mathrm{C} 32$ & $\mathrm{C} 33$ & $119.9(2)$ \\
$\mathrm{C} 32$ & $\mathrm{C} 33$ & $\mathrm{H} 33$ & $120.0(2)$ \\
$\mathrm{C} 32$ & $\mathrm{C} 33$ & $\mathrm{C} 34$ & $120.0(2)$ \\
$\mathrm{H} 33$ & $\mathrm{C} 33$ & $\mathrm{C} 34$ & $120.0(2)$ \\
$\mathrm{C} 33$ & $\mathrm{C} 34$ & $\mathrm{H} 34$ & $120.0(2)$ \\
$\mathrm{C} 33$ & $\mathrm{C} 34$ & $\mathrm{C} 35$ & $120.0(2)$ \\
$\mathrm{H} 34$ & $\mathrm{C} 34$ & $\mathrm{C} 35$ & $120.0(2)$ \\
$\mathrm{C} 30$ & $\mathrm{C} 35$ & $\mathrm{C} 34$ & $120.3(2)$ \\
$\mathrm{C} 30$ & $\mathrm{C} 35$ & $\mathrm{H} 35$ & $119.8(2)$ \\
$\mathrm{C} 34$ & $\mathrm{C} 35$ & $\mathrm{H} 35$ & $119.9(2)$ \\
$\mathrm{C} 2$ & $\mathrm{~N} 1$ & $\mathrm{C} 3$ & $129.2(1)$ \\
$\mathrm{C} 2$ & $\mathrm{~N} 1$ & $\mathrm{H} 1$ & $118(1)$ \\
$\mathrm{C} 3$ & $\mathrm{~N} 1$ & $\mathrm{H} 1$ & $112(1)$ \\
$\mathrm{C} 9$ & $\mathrm{~N} 2$ & $\mathrm{C} 11$ & $109.5(2)$ \\
$\mathrm{C} 9$ & $\mathrm{O} 3$ & $\mathrm{C} 10$ & $107.2(3)$ \\
$\mathrm{C} 1$ & $\mathrm{P} 1$ & $\mathrm{C} 20$ & $104.28(7)$ \\
$\mathrm{C} 1$ & $\mathrm{P} 1$ & $\mathrm{C} 30$ & $108.06(8)$ \\
$\mathrm{C} 1$ & $\mathrm{P} 1$ & $\mathrm{O} 1$ & $112.64(7)$ \\
$\mathrm{C} 20$ & $\mathrm{P} 1$ & $\mathrm{C} 30$ & $106.33(7)$ \\
$\mathrm{C} 20$ & $\mathrm{P} 1$ & $\mathrm{O} 1$ & $113.09(7)$ \\
$\mathrm{C} 30$ & $\mathrm{P} 1$ & $\mathrm{O} 1$ & $111.92(7)$ \\
$\mathrm{H} 40 \mathrm{~A}$ & $\mathrm{O} 40$ & $\mathrm{H} 40 \mathrm{~B}$ & $103(2)$ \\
\hline & & & \\
& & &
\end{tabular}


Table A7. Torsion angles $\left[^{\circ}\right]$ for $3 \mathrm{~m} \bullet$ oxide

\begin{tabular}{lllll}
\hline $\mathrm{H} 1 \mathrm{~A}$ & $\mathrm{C} 1$ & $\mathrm{C} 2$ & $\mathrm{~N} 1$ & $-15.8(2)$ \\
$\mathrm{H} 1 \mathrm{~A}$ & $\mathrm{C} 1$ & $\mathrm{C} 2$ & $\mathrm{O} 2$ & $163.0(1)$ \\
$\mathrm{H} 1 \mathrm{~B}$ & $\mathrm{C} 1$ & $\mathrm{C} 2$ & $\mathrm{~N} 1$ & $-133.4(2)$ \\
$\mathrm{H} 1 \mathrm{~B}$ & $\mathrm{C} 1$ & $\mathrm{C} 2$ & $\mathrm{O} 2$ & $45.4(2)$ \\
$\mathrm{P} 1$ & $\mathrm{C} 1$ & $\mathrm{C} 2$ & $\mathrm{~N} 1$ & $105.4(1)$ \\
$\mathrm{P} 1$ & $\mathrm{C} 1$ & $\mathrm{C} 2$ & $\mathrm{O} 2$ & $-75.8(2)$ \\
$\mathrm{H} 1 \mathrm{~A}$ & $\mathrm{C} 1$ & $\mathrm{P} 1$ & $\mathrm{C} 20$ & $-57.7(1)$ \\
$\mathrm{H} 1 \mathrm{~A}$ & $\mathrm{C} 1$ & $\mathrm{P} 1$ & $\mathrm{C} 30$ & $-170.5(1)$ \\
$\mathrm{H} 1 \mathrm{~A}$ & $\mathrm{C} 1$ & $\mathrm{P} 1$ & $\mathrm{O} 1$ & $65.3(1)$ \\
$\mathrm{H} 1 \mathrm{~B}$ & $\mathrm{C} 1$ & $\mathrm{P} 1$ & $\mathrm{C} 20$ & $59.9(1)$ \\
$\mathrm{H} 1 \mathrm{~B}$ & $\mathrm{C} 1$ & $\mathrm{P} 1$ & $\mathrm{C} 30$ & $-52.9(1)$ \\
$\mathrm{H} 1 \mathrm{~B}$ & $\mathrm{C} 1$ & $\mathrm{P} 1$ & $\mathrm{O} 1$ & $-177.1(1)$ \\
$\mathrm{C} 2$ & $\mathrm{C} 1$ & $\mathrm{P} 1$ & $\mathrm{C} 20$ & $-178.9(1)$ \\
$\mathrm{C} 2$ & $\mathrm{C} 1$ & $\mathrm{P} 1$ & $\mathrm{C} 30$ & $68.3(1)$ \\
$\mathrm{C} 2$ & $\mathrm{C} 1$ & $\mathrm{P} 1$ & $\mathrm{O} 1$ & $-55.9(1)$ \\
$\mathrm{C} 1$ & $\mathrm{C} 2$ & $\mathrm{~N} 1$ & $\mathrm{C} 3$ & $174.1(2)$ \\
$\mathrm{C} 1$ & $\mathrm{C} 2$ & $\mathrm{~N} 1$ & $\mathrm{H} 1$ & $-3(1)$ \\
$\mathrm{O} 2$ & $\mathrm{C} 2$ & $\mathrm{~N} 1$ & $\mathrm{C} 3$ & $-4.6(3)$ \\
$\mathrm{O} 2$ & $\mathrm{C} 2$ & $\mathrm{~N} 1$ & $\mathrm{H} 1$ & $179(1)$ \\
$\mathrm{C} 8$ & $\mathrm{C} 3$ & $\mathrm{C} 4$ & $\mathrm{H} 4$ & $178.8(2)$ \\
$\mathrm{C} 8$ & $\mathrm{C} 3$ & $\mathrm{C} 4$ & $\mathrm{C} 5$ & $-1.2(2)$ \\
$\mathrm{N} 1$ & $\mathrm{C} 3$ & $\mathrm{C} 4$ & $\mathrm{H} 4$ & $-1.6(3)$ \\
$\mathrm{N} 1$ & $\mathrm{C} 3$ & $\mathrm{C} 4$ & $\mathrm{C} 5$ & $178.4(2)$ \\
$\mathrm{C} 4$ & $\mathrm{C} 3$ & $\mathrm{C} 8$ & $\mathrm{C} 7$ & $1.2(2)$ \\
$\mathrm{C} 4$ & $\mathrm{C} 3$ & $\mathrm{C} 8$ & $\mathrm{C} 9$ & $179.4(2)$ \\
$\mathrm{N} 1$ & $\mathrm{C} 3$ & $\mathrm{C} 8$ & $\mathrm{C} 7$ & $-178.5(2)$ \\
$\mathrm{N} 1$ & $\mathrm{C} 3$ & $\mathrm{C} 8$ & $\mathrm{C} 9$ & $-0.3(2)$ \\
$\mathrm{C} 4$ & $\mathrm{C} 3$ & $\mathrm{~N} 1$ & $\mathrm{C} 2$ & $9.8(3)$ \\
$\mathrm{C} 4$ & $\mathrm{C} 3$ & $\mathrm{~N} 1$ & $\mathrm{H} 1$ & $-173(1)$ \\
$\mathrm{C} 8$ & $\mathrm{C} 3$ & $\mathrm{~N} 1$ & $\mathrm{C} 2$ & $-170.5(2)$ \\
$\mathrm{C} 8$ & $\mathrm{C} 3$ & $\mathrm{~N} 1$ & $\mathrm{H} 1$ & $6(1)$ \\
$\mathrm{C} 3$ & $\mathrm{C} 4$ & $\mathrm{C} 5$ & $\mathrm{H} 5$ & $-179.6(2)$ \\
$\mathrm{C} 3$ & $\mathrm{C} 4$ & $\mathrm{C} 5$ & $\mathrm{C} 6$ & $0.3(3)$ \\
$\mathrm{H} 4$ & $\mathrm{C} 4$ & $\mathrm{C} 5$ & $\mathrm{H} 5$ & $0.4(3)$ \\
$\mathrm{H} 4$ & $\mathrm{C} 4$ & $\mathrm{C} 5$ & $\mathrm{C} 6$ & $-179.7(2)$ \\
$\mathrm{C} 4$ & $\mathrm{C} 5$ & $\mathrm{C} 6$ & $\mathrm{H} 6$ & $-179.5(2)$ \\
$\mathrm{C} 4$ & $\mathrm{C} 5$ & $\mathrm{C} 6$ & $\mathrm{C} 7$ & $0.6(3)$ \\
$\mathrm{H} 5$ & $\mathrm{C} 5$ & $\mathrm{C} 6$ & $\mathrm{H} 6$ & $0.5(3)$ \\
$\mathrm{H} 5$ & $\mathrm{C} 5$ & $\mathrm{C} 6$ & $\mathrm{C} 7$ & $-179.4(2)$ \\
$\mathrm{C} 5$ & $\mathrm{C} 6$ & $\mathrm{C} 7$ & $\mathrm{H} 7$ & $179.3(2)$ \\
$\mathrm{C} 5$ & $\mathrm{C} 6$ & $\mathrm{C} 7$ & $\mathrm{C} 8$ & $-0.7(3)$ \\
& & & &
\end{tabular}




\begin{tabular}{|c|c|c|c|c|}
\hline $\mathrm{H} 6$ & C6 & $\mathrm{C} 7$ & $\mathrm{H} 7$ & $-0.6(3)$ \\
\hline $\mathrm{H} 6$ & $\mathrm{C} 6$ & C7 & C8 & $179.4(2)$ \\
\hline C6 & C7 & C8 & C3 & $-0.2(3)$ \\
\hline C6 & $\mathrm{C} 7$ & C8 & C9 & $-178.5(2)$ \\
\hline $\mathrm{H} 7$ & $\mathrm{C} 7$ & C8 & C3 & $179.8(2)$ \\
\hline $\mathrm{H} 7$ & C7 & C8 & C9 & $1.4(3)$ \\
\hline $\mathrm{C} 3$ & $\mathrm{C} 8$ & $\mathrm{C} 9$ & N2 & $-6.3(3)$ \\
\hline $\mathrm{C} 3$ & $\mathrm{C} 8$ & $\mathrm{C} 9$ & $\mathrm{O} 3$ & $175.7(2)$ \\
\hline $\mathrm{C} 7$ & $\mathrm{C} 8$ & $\mathrm{C} 9$ & N2 & $171.9(2)$ \\
\hline $\mathrm{C} 7$ & $\mathrm{C} 8$ & C9 & $\mathrm{O} 3$ & $-6.0(3)$ \\
\hline $\mathrm{C} 8$ & c9 & N2 & C11 & $-178.6(2)$ \\
\hline $\mathrm{O} 3$ & c9 & N2 & C11 & $-0.7(3)$ \\
\hline $\mathrm{C} 8$ & $\mathrm{C} 9$ & $\mathrm{O} 3$ & C10 & $178.8(2)$ \\
\hline $\mathrm{N} 2$ & C9 & $\mathrm{O} 3$ & C10 & $0.6(3)$ \\
\hline $\mathrm{H} 10 \mathrm{~A}$ & $\mathrm{C} 10$ & $\mathrm{C} 11$ & $\mathrm{C} 12$ & 1.1(4) \\
\hline $\mathrm{H} 10 \mathrm{~A}$ & $\mathrm{C} 10$ & C11 & $\mathrm{C} 13$ & $-124.1(3)$ \\
\hline $\mathrm{H} 10 \mathrm{~A}$ & $\mathrm{C} 10$ & C11 & N2 & 119.3(3) \\
\hline $\mathrm{H} 10 \mathrm{~B}$ & C10 & C11 & $\mathrm{C} 12$ & $122.3(3)$ \\
\hline $\mathrm{H} 10 \mathrm{~B}$ & C10 & C11 & C13 & $-2.9(4)$ \\
\hline $\mathrm{H} 10 \mathrm{~B}$ & C10 & C11 & N2 & $-119.5(3)$ \\
\hline $\mathrm{O} 3$ & C10 & C11 & $\mathrm{C} 12$ & $-118.3(3)$ \\
\hline $\mathrm{O} 3$ & $\mathrm{C} 10$ & C11 & $\mathrm{C} 13$ & $116.5(3)$ \\
\hline $\mathrm{O} 3$ & $\mathrm{C} 10$ & C11 & $\mathrm{N} 2$ & $-0.1(3)$ \\
\hline $\mathrm{H} 10 \mathrm{~A}$ & $\mathrm{C} 10$ & $\mathrm{O} 3$ & $\mathrm{C9}$ & $-119.7(3)$ \\
\hline $\mathrm{H} 10 \mathrm{~B}$ & C10 & $\mathrm{O} 3$ & C9 & 119.1(3) \\
\hline C11 & C10 & $\mathrm{O} 3$ & C9 & $-0.3(3)$ \\
\hline C10 & C11 & $\mathrm{C} 12$ & $\mathrm{H} 12 \mathrm{~A}$ & $-68.7(4)$ \\
\hline C10 & $\mathrm{C} 11$ & $\mathrm{C} 12$ & $\mathrm{H} 12 \mathrm{~B}$ & 171.3(3) \\
\hline $\mathrm{C} 10$ & $\mathrm{C} 11$ & $\mathrm{C} 12$ & $\mathrm{H} 12 \mathrm{C}$ & $51.4(4)$ \\
\hline $\mathrm{C} 13$ & $\mathrm{C} 11$ & $\mathrm{C} 12$ & $\mathrm{H} 12 \mathrm{~A}$ & $57.3(3)$ \\
\hline C13 & C11 & C12 & $\mathrm{H} 12 \mathrm{~B}$ & $-62.7(3)$ \\
\hline C13 & C11 & C12 & $\mathrm{H} 12 \mathrm{C}$ & $177.4(3)$ \\
\hline N2 & C11 & C12 & $\mathrm{H} 12 \mathrm{~A}$ & $177.7(2)$ \\
\hline N2 & C11 & C12 & $\mathrm{H} 12 \mathrm{~B}$ & $57.7(3)$ \\
\hline N2 & C11 & C12 & $\mathrm{H} 12 \mathrm{C}$ & $-62.3(3)$ \\
\hline C10 & C11 & C13 & $\mathrm{H} 13 \mathrm{~A}$ & $66.8(3)$ \\
\hline C10 & C11 & C13 & $\mathrm{H} 13 \mathrm{~B}$ & $-53.2(3)$ \\
\hline C10 & C11 & C13 & $\mathrm{H} 13 \mathrm{C}$ & $-173.2(2)$ \\
\hline C12 & C11 & C13 & $\mathrm{H} 13 \mathrm{~A}$ & $-60.2(3)$ \\
\hline C12 & C11 & C13 & H13B & $179.8(2)$ \\
\hline C12 & C11 & C13 & $\mathrm{H} 13 \mathrm{C}$ & $59.9(3)$ \\
\hline N2 & C11 & C13 & $\mathrm{H} 13 \mathrm{~A}$ & $179.0(2)$ \\
\hline N2 & C11 & C13 & H13B & $59.0(3)$ \\
\hline
\end{tabular}




\begin{tabular}{|c|c|c|c|c|}
\hline N2 & C11 & C13 & $\mathrm{H} 13 \mathrm{C}$ & $-60.9(3)$ \\
\hline C10 & C11 & N2 & $\mathrm{C9}$ & $0.4(2)$ \\
\hline C12 & C11 & N2 & C9 & $121.1(2)$ \\
\hline C13 & C11 & N2 & C9 & $-117.9(2)$ \\
\hline C25 & $\mathrm{C} 20$ & C21 & $\mathrm{H} 21$ & $-179.7(2)$ \\
\hline $\mathrm{C} 25$ & $\mathrm{C} 20$ & C21 & $\mathrm{C} 22$ & $0.4(2)$ \\
\hline P1 & $\mathrm{C} 20$ & C21 & $\mathrm{H} 21$ & $-2.0(2)$ \\
\hline P1 & $\mathrm{C} 20$ & C21 & $\mathrm{C} 22$ & $178.0(1)$ \\
\hline C21 & $\mathrm{C} 20$ & C25 & C24 & $-0.1(2)$ \\
\hline C21 & $\mathrm{C} 20$ & C25 & $\mathrm{H} 25$ & $179.9(2)$ \\
\hline P1 & $\mathrm{C} 20$ & C25 & C24 & $-177.5(1)$ \\
\hline P1 & $\mathrm{C} 20$ & $\mathrm{C} 25$ & $\mathrm{H} 25$ & $2.5(3)$ \\
\hline C21 & C20 & P1 & C1 & $144.4(1)$ \\
\hline C21 & $\mathrm{C} 20$ & P1 & C30 & $-101.5(1)$ \\
\hline C21 & C20 & P1 & 01 & $21.7(2)$ \\
\hline $\mathrm{C} 25$ & $\mathrm{C} 20$ & P1 & C1 & $-38.1(2)$ \\
\hline $\mathrm{C} 25$ & C20 & P1 & C30 & $76.0(2)$ \\
\hline $\mathrm{C} 25$ & C20 & $\mathrm{P} 1$ & 01 & $-160.8(1)$ \\
\hline C20 & C21 & C22 & $\mathrm{H} 22$ & $179.7(2)$ \\
\hline C20 & $\mathrm{C} 21$ & C22 & C23 & $-0.3(3)$ \\
\hline $\mathrm{H} 21$ & C21 & C22 & $\mathrm{H} 22$ & $-0.3(3)$ \\
\hline $\mathrm{H} 21$ & C21 & C22 & $\mathrm{C} 23$ & $179.7(2)$ \\
\hline $\mathrm{C} 21$ & $\mathrm{C} 22$ & C23 & $\mathrm{H} 23$ & $180.0(2)$ \\
\hline $\mathrm{C} 21$ & $\mathrm{C} 22$ & C23 & $\mathrm{C} 24$ & $-0.0(3)$ \\
\hline $\mathrm{H} 22$ & $\mathrm{C} 22$ & C23 & $\mathrm{H} 23$ & $-0.0(3)$ \\
\hline $\mathrm{H} 22$ & $\mathrm{C} 22$ & C23 & $\mathrm{C} 24$ & $180.0(2)$ \\
\hline $\mathrm{C} 22$ & $\mathrm{C} 23$ & C24 & $\mathrm{H} 24$ & $-179.6(2)$ \\
\hline $\mathrm{C} 22$ & $\mathrm{C} 23$ & C24 & $\mathrm{C} 25$ & $0.3(3)$ \\
\hline $\mathrm{H} 23$ & $\mathrm{C} 23$ & C24 & $\mathrm{H} 24$ & $0.4(3)$ \\
\hline $\mathrm{H} 23$ & $\mathrm{C} 23$ & C24 & $\mathrm{C} 25$ & $-179.7(2)$ \\
\hline C23 & $\mathrm{C} 24$ & C25 & C20 & $-0.3(3)$ \\
\hline C23 & $\mathrm{C} 24$ & C25 & $\mathrm{H} 25$ & $179.7(2)$ \\
\hline $\mathrm{H} 24$ & C24 & $\mathrm{C} 25$ & C20 & $179.7(2)$ \\
\hline $\mathrm{H} 24$ & $\mathrm{C} 24$ & C25 & $\mathrm{H} 25$ & $-0.3(3)$ \\
\hline C35 & C30 & C31 & H31 & $179.8(2)$ \\
\hline C35 & C30 & C31 & C32 & $-0.2(3)$ \\
\hline P1 & C30 & C31 & H31 & $3.3(3)$ \\
\hline P1 & C30 & C31 & C32 & $-176.6(1)$ \\
\hline C31 & C30 & C35 & C34 & $0.3(3)$ \\
\hline C31 & C30 & C35 & H35 & $-179.7(2)$ \\
\hline P1 & C30 & C35 & C34 & $176.7(1)$ \\
\hline P1 & C30 & C35 & H35 & $-3.3(2)$ \\
\hline C31 & C30 & P1 & C1 & $-132.0(1)$ \\
\hline
\end{tabular}




\begin{tabular}{lllll} 
C31 & C30 & P1 & C20 & $116.5(1)$ \\
C31 & C30 & P1 & O1 & $-7.4(2)$ \\
C35 & C30 & P1 & C1 & $51.6(2)$ \\
C35 & C30 & P1 & C20 & $-59.8(2)$ \\
C35 & C30 & P1 & O1 & $176.2(1)$ \\
C30 & C31 & C32 & H32 & $-180.0(2)$ \\
C30 & C31 & C32 & C33 & $0.0(3)$ \\
H31 & C31 & C32 & H32 & $0.1(3)$ \\
H31 & C31 & C32 & C33 & $-180.0(2)$ \\
C31 & C32 & C33 & H33 & $180.0(2)$ \\
C31 & C32 & C33 & C34 & $-0.0(3)$ \\
H32 & C32 & C33 & H33 & $-0.0(3)$ \\
H32 & C32 & C33 & C34 & $180.0(2)$ \\
C32 & C33 & C34 & H34 & $-179.7(2)$ \\
C32 & C33 & C34 & C35 & $0.2(3)$ \\
H33 & C33 & C34 & H34 & $0.3(3)$ \\
H33 & C33 & C34 & C35 & $-179.8(2)$ \\
C33 & C34 & C35 & C30 & $-0.4(3)$ \\
C33 & C34 & C35 & H35 & $179.6(2)$ \\
H34 & C34 & C35 & C30 & $179.5(2)$ \\
H34 & C34 & C35 & H35 & $-0.5(3)$ \\
\hline
\end{tabular}

Table A8. Bond lengths $[\AA]$ for 6

\begin{tabular}{lll}
\hline Cl1 & C17 & $1.782(3)$ \\
N1 & HN1 & $0.879(2)$ \\
N1 & C11 & $1.408(3)$ \\
N1 & C16 & $1.354(3)$ \\
C10 & C18 & $1.470(3)$ \\
C10 & C11 & $1.415(3)$ \\
C10 & C15 & $1.397(3)$ \\
O1 & C16 & $1.218(3)$ \\
O2 & C18 & $1.360(3)$ \\
O2 & C8 & $1.456(3)$ \\
C18 & N2 & $1.279(3)$ \\
C11 & C12 & $1.398(3)$ \\
C16 & C17 & $1.518(3)$ \\
C15 & H15 & $0.950(3)$ \\
C15 & C14 & $1.379(4)$ \\
N2 & C9 & $1.477(3)$
\end{tabular}




\begin{tabular}{|c|c|c|}
\hline C5 & C9 & $1.493(3)$ \\
\hline C5 & C6 & $1.387(3)$ \\
\hline C5 & C4 & $1.387(4)$ \\
\hline C9 & $\mathrm{H} 9$ & $1.000(3)$ \\
\hline C9 & C8 & $1.548(4)$ \\
\hline C6 & C1 & $1.386(4)$ \\
\hline C6 & $\mathrm{C} 7$ & $1.510(4)$ \\
\hline C13 & $\mathrm{H} 13$ & $0.949(3)$ \\
\hline C13 & C12 & $1.386(3)$ \\
\hline C13 & C14 & $1.378(4)$ \\
\hline C12 & $\mathrm{H} 12$ & $0.950(2)$ \\
\hline C1 & $\mathrm{H} 1$ & $0.950(3)$ \\
\hline C1 & $\mathrm{C} 2$ & $1.385(4)$ \\
\hline C3 & $\mathrm{H} 3$ & $0.950(3)$ \\
\hline C3 & $\mathrm{C} 2$ & $1.388(4)$ \\
\hline C3 & C4 & $1.391(4)$ \\
\hline C14 & $\mathrm{H} 14$ & $0.950(3)$ \\
\hline C17 & $\mathrm{H} 17 \mathrm{~A}$ & $0.990(2)$ \\
\hline C17 & H17B & $0.990(3)$ \\
\hline C8 & $\mathrm{H} 8$ & $1.000(2)$ \\
\hline C8 & $\mathrm{C7}$ & $1.537(4)$ \\
\hline $\mathrm{C} 7$ & $\mathrm{H} 7 \mathrm{~A}$ & $0.990(3)$ \\
\hline C7 & $\mathrm{H} 7 \mathrm{~B}$ & $0.990(3)$ \\
\hline C2 & $\mathrm{H} 2$ & $0.949(3)$ \\
\hline C4 & $\mathrm{H} 4$ & $0.950(3)$ \\
\hline
\end{tabular}

Table A9. Select angles $\left[{ }^{\circ}\right]$ for 6

\begin{tabular}{llll}
\hline HN1 & N1 & C11 & $116.6(2)$ \\
HN1 & N1 & C16 & $116.7(2)$ \\
C11 & N1 & C16 & $126.7(2)$ \\
C18 & C10 & C11 & $122.4(2)$ \\
C18 & C10 & C15 & $118.2(2)$ \\
C11 & C10 & C15 & $119.4(2)$ \\
C18 & O2 & C8 & $106.5(2)$ \\
C10 & C18 & O2 & $115.4(2)$ \\
C10 & C18 & N2 & $126.7(2)$ \\
O2 & C18 & N2 & $117.9(2)$ \\
N1 & C11 & C10 & $118.8(2)$ \\
N1 & C11 & C12 & $122.6(2)$
\end{tabular}




\begin{tabular}{|c|c|c|c|}
\hline C10 & C11 & C12 & $118.6(2)$ \\
\hline N1 & C16 & 01 & $125.8(2)$ \\
\hline N1 & C16 & C17 & $118.1(2)$ \\
\hline 01 & C16 & C17 & 116.1(2) \\
\hline C10 & C15 & $\mathrm{H} 15$ & $119.4(2)$ \\
\hline C10 & C15 & C14 & $121.0(2)$ \\
\hline $\mathrm{H} 15$ & C15 & C14 & $119.6(2)$ \\
\hline C18 & $\mathrm{N} 2$ & C9 & $107.4(2)$ \\
\hline $\mathrm{C9}$ & C5 & C6 & $111.5(2)$ \\
\hline C9 & C5 & C4 & $128.3(2)$ \\
\hline C6 & C5 & C4 & $120.2(2)$ \\
\hline N2 & C9 & C5 & $113.0(2)$ \\
\hline N2 & C9 & $\mathrm{H} 9$ & $111.5(2)$ \\
\hline N2 & C9 & $\mathrm{C} 8$ & $104.2(2)$ \\
\hline C5 & C9 & $\mathrm{H} 9$ & $111.4(2)$ \\
\hline C5 & C9 & C8 & $104.8(2)$ \\
\hline H9 & C9 & C8 & 111.4(2) \\
\hline C5 & C6 & C1 & $120.4(2)$ \\
\hline C5 & C6 & $\mathrm{C} 7$ & $111.6(2)$ \\
\hline C1 & C6 & C7 & $128.0(2)$ \\
\hline $\mathrm{H} 13$ & $\mathrm{C} 13$ & C12 & $119.5(2)$ \\
\hline $\mathrm{H} 13$ & $\mathrm{C} 13$ & C14 & $119.5(3)$ \\
\hline C12 & C13 & C14 & $121.0(2)$ \\
\hline C11 & C12 & C13 & $120.4(2)$ \\
\hline C11 & $\mathrm{C} 12$ & $\mathrm{H} 12$ & $119.8(2)$ \\
\hline C13 & C12 & $\mathrm{H} 12$ & $119.8(2)$ \\
\hline C6 & C1 & $\mathrm{H} 1$ & $120.6(3)$ \\
\hline C6 & C1 & $\mathrm{C} 2$ & $118.9(2)$ \\
\hline $\mathrm{H} 1$ & C1 & $\mathrm{C} 2$ & $120.5(3)$ \\
\hline H3 & C3 & $\mathrm{C} 2$ & $120.5(3)$ \\
\hline H3 & C3 & C4 & $120.5(3)$ \\
\hline $\mathrm{C} 2$ & $\mathrm{C} 3$ & C4 & $119.0(3)$ \\
\hline C15 & C14 & C13 & $119.5(2)$ \\
\hline C15 & C14 & $\mathrm{H} 14$ & $120.2(3)$ \\
\hline C13 & C14 & $\mathrm{H} 14$ & 120.3(3) \\
\hline $\mathrm{Cl} 1$ & C17 & C16 & $116.5(2)$ \\
\hline $\mathrm{Cl} 1$ & C17 & $\mathrm{H} 17 \mathrm{~A}$ & 108.2(2) \\
\hline $\mathrm{Cl} 1$ & C17 & H17B & 108.2(2) \\
\hline C16 & C17 & $\mathrm{H} 17 \mathrm{~A}$ & 108.2(2) \\
\hline C16 & C17 & H17B & 108.1(2) \\
\hline $\mathrm{H} 17 \mathrm{~A}$ & C17 & $\mathrm{H} 17 \mathrm{~B}$ & $107.3(2)$ \\
\hline $\mathrm{O} 2$ & $\mathrm{C} 8$ & $\mathrm{Cg}$ & $103.9(2)$ \\
\hline $\mathrm{O} 2$ & C8 & $\mathrm{H} 8$ & $111.2(2)$ \\
\hline
\end{tabular}




\begin{tabular}{llll} 
O2 & C8 & C7 & $111.5(2)$ \\
C9 & C8 & H8 & $111.2(2)$ \\
C9 & C8 & C7 & $107.6(2)$ \\
H8 & C8 & C7 & $111.2(2)$ \\
C6 & C7 & C8 & $104.4(2)$ \\
C6 & C7 & H7A & $110.9(2)$ \\
C6 & C7 & H7B & $110.9(2)$ \\
C8 & C7 & H7A & $110.9(2)$ \\
C8 & C7 & H7B & $110.9(2)$ \\
H7A & C7 & H7B & $108.9(2)$ \\
C1 & C2 & C3 & $121.5(3)$ \\
C1 & C2 & H2 & $119.3(3)$ \\
C3 & C2 & H2 & $119.2(3)$ \\
C5 & C4 & C3 & $120.0(2)$ \\
C5 & C4 & H4 & $120.0(3)$ \\
C3 & C4 & H4 & $120.0(3)$ \\
\hline
\end{tabular}

Table A10. Select torsion angles $\left[{ }^{\circ}\right]$ for 6

\begin{tabular}{lllll}
\hline HN1 & N1 & C11 & C10 & $-7.3(3)$ \\
HN1 & N1 & C11 & C12 & $172.0(2)$ \\
C16 & N1 & C11 & C10 & $172.7(2)$ \\
C16 & N1 & C11 & C12 & $-7.9(4)$ \\
HN1 & N1 & C16 & O1 & $-179.0(2)$ \\
HN1 & N1 & C16 & C17 & $2.1(3)$ \\
C11 & N1 & C16 & O1 & $1.0(4)$ \\
C11 & N1 & C16 & C17 & $-177.9(2)$ \\
C11 & C10 & C18 & O2 & $-169.4(2)$ \\
C11 & C10 & C18 & N2 & $11.8(4)$ \\
C15 & C10 & C18 & O2 & $12.0(3)$ \\
C15 & C10 & C18 & N2 & $-166.8(2)$ \\
C18 & C10 & C11 & N1 & $1.0(3)$ \\
C18 & C10 & C11 & C12 & $-178.4(2)$ \\
C15 & C10 & C11 & N1 & $179.6(2)$ \\
C15 & C10 & C11 & C12 & $0.2(3)$ \\
C18 & C10 & C15 & H15 & $-1.6(4)$ \\
C18 & C10 & C15 & C14 & $178.5(2)$ \\
C11 & C10 & C15 & H15 & $179.8(2)$ \\
C11 & C10 & C15 & C14 & $-0.1(4)$ \\
C8 & O2 & C18 & C10 & $179.1(2)$ \\
& & & &
\end{tabular}




\begin{tabular}{|c|c|c|c|c|}
\hline C8 & $\mathrm{O} 2$ & C18 & N2 & $-2.0(3)$ \\
\hline C18 & $\mathrm{O} 2$ & $\mathrm{C} 8$ & $\mathrm{C9}$ & $3.4(2)$ \\
\hline C18 & $\mathrm{O} 2$ & C8 & $\mathrm{H} 8$ & $123.1(2)$ \\
\hline C18 & $\mathrm{O} 2$ & C8 & C7 & $-112.2(2)$ \\
\hline C10 & C18 & N2 & C9 & 178.3(2) \\
\hline $\mathrm{O} 2$ & C18 & $\mathrm{N} 2$ & C9 & $-0.6(3)$ \\
\hline N1 & C11 & $\mathrm{C} 12$ & $\mathrm{C} 13$ & $-179.6(2)$ \\
\hline N1 & C11 & $\mathrm{C} 12$ & $\mathrm{H} 12$ & $0.4(4)$ \\
\hline C10 & C11 & $\mathrm{C} 12$ & C13 & $-0.3(3)$ \\
\hline C10 & C11 & C12 & $\mathrm{H} 12$ & $179.7(2)$ \\
\hline $\mathrm{N} 1$ & C16 & C17 & $\mathrm{Cl} 1$ & $-5.1(3)$ \\
\hline $\mathrm{N} 1$ & C16 & C17 & $\mathrm{H} 17 \mathrm{~A}$ & $-127.1(2)$ \\
\hline N1 & $\mathrm{C} 16$ & C17 & H17B & $116.9(2)$ \\
\hline O1 & C16 & C17 & $\mathrm{Cl} 1$ & $175.9(2)$ \\
\hline O1 & C16 & C17 & $\mathrm{H} 17 \mathrm{~A}$ & $53.9(3)$ \\
\hline O1 & C16 & C17 & H17B & $-62.1(3)$ \\
\hline C10 & C15 & C14 & C13 & $0.1(4)$ \\
\hline C10 & C15 & C14 & $\mathrm{H} 14$ & $-179.9(2)$ \\
\hline $\mathrm{H} 15$ & C15 & C14 & C13 & $-179.8(2)$ \\
\hline $\mathrm{H} 15$ & C15 & C14 & $\mathrm{H} 14$ & $0.1(4)$ \\
\hline C18 & $\mathrm{N} 2$ & $\mathrm{Cg}$ & C5 & $115.9(2)$ \\
\hline C18 & $\mathrm{N} 2$ & C9 & $\mathrm{H} 9$ & $-117.6(2)$ \\
\hline C18 & $\mathrm{N} 2$ & C9 & $\mathrm{C} 8$ & $2.7(2)$ \\
\hline C6 & C5 & C9 & N2 & $-109.4(2)$ \\
\hline C6 & C5 & C9 & H9 & 124.1(2) \\
\hline C6 & C5 & C9 & C8 & $3.5(3)$ \\
\hline C4 & C5 & C9 & N2 & $70.5(3)$ \\
\hline C4 & C5 & C9 & $\mathrm{H} 9$ & $-56.0(3)$ \\
\hline C4 & C5 & C9 & $\mathrm{C} 8$ & $-176.6(2)$ \\
\hline C9 & C5 & C6 & C1 & 179.1(2) \\
\hline C9 & C5 & C6 & $\mathrm{C} 7$ & $-1.2(3)$ \\
\hline C4 & C5 & C6 & C1 & $-0.8(4)$ \\
\hline C4 & C5 & C6 & $\mathrm{C} 7$ & $178.9(2)$ \\
\hline C9 & C5 & C4 & C3 & $-178.9(2)$ \\
\hline C9 & C5 & C4 & $\mathrm{H} 4$ & $1.1(4)$ \\
\hline C6 & C5 & $\mathrm{C} 4$ & C3 & $1.0(4)$ \\
\hline C6 & C5 & $\mathrm{C} 4$ & $\mathrm{H} 4$ & $-179.0(2)$ \\
\hline N2 & C9 & $\mathrm{C} 8$ & $\mathrm{O} 2$ & $-3.6(2)$ \\
\hline N2 & C9 & C8 & $\mathrm{H} 8$ & $-123.3(2)$ \\
\hline N2 & C9 & C8 & C7 & $114.6(2)$ \\
\hline C5 & C9 & C8 & $\mathrm{O} 2$ & $-122.6(2)$ \\
\hline C5 & C9 & C8 & $\mathrm{H} 8$ & $117.7(2)$ \\
\hline C5 & C9 & C8 & C7 & $-4.4(3)$ \\
\hline
\end{tabular}




\begin{tabular}{|c|c|c|c|c|}
\hline $\mathrm{H} 9$ & C9 & $\mathrm{C} 8$ & $\mathrm{O} 2$ & $116.7(2)$ \\
\hline $\mathrm{H} 9$ & C9 & $\mathrm{C} 8$ & $\mathrm{H} 8$ & $-3.0(3)$ \\
\hline H9 & C9 & C8 & $\mathrm{C} 7$ & $-125.0(2)$ \\
\hline C5 & C6 & C1 & $\mathrm{H} 1$ & $180.0(2)$ \\
\hline C5 & C6 & C1 & $\mathrm{C} 2$ & $-0.0(4)$ \\
\hline $\mathrm{C7}$ & C6 & C1 & $\mathrm{H} 1$ & $0.4(4)$ \\
\hline $\mathrm{C} 7$ & $\mathrm{C} 6$ & $\mathrm{C} 1$ & $\mathrm{C} 2$ & $-179.6(2)$ \\
\hline $\mathrm{C} 5$ & $\mathrm{C} 6$ & $\mathrm{C} 7$ & $\mathrm{C} 8$ & $-1.6(3)$ \\
\hline C5 & $\mathrm{C} 6$ & $\mathrm{C} 7$ & $\mathrm{H} 7 \mathrm{~A}$ & $-121.1(2)$ \\
\hline C5 & $\mathrm{C} 6$ & $\mathrm{C} 7$ & $\mathrm{H} 7 \mathrm{~B}$ & $117.8(2)$ \\
\hline C1 & $\mathrm{C} 6$ & $\mathrm{C} 7$ & $\mathrm{C} 8$ & 178.0(3) \\
\hline C1 & $\mathrm{C} 6$ & $\mathrm{C} 7$ & $\mathrm{H} 7 \mathrm{~A}$ & $58.5(4)$ \\
\hline C1 & $\mathrm{C} 6$ & $\mathrm{C} 7$ & $\mathrm{H} 7 \mathrm{~B}$ & $-62.5(4)$ \\
\hline $\mathrm{H} 13$ & $\mathrm{C} 13$ & $\mathrm{C} 12$ & $\mathrm{C} 11$ & $-179.7(2)$ \\
\hline $\mathrm{H} 13$ & $\mathrm{C} 13$ & $\mathrm{C} 12$ & $\mathrm{H} 12$ & $0.3(4)$ \\
\hline C14 & $\mathrm{C} 13$ & $\mathrm{C} 12$ & $\mathrm{C} 11$ & $0.3(4)$ \\
\hline C14 & $\mathrm{C} 13$ & $\mathrm{C} 12$ & $\mathrm{H} 12$ & $-179.7(2)$ \\
\hline $\mathrm{H} 13$ & $\mathrm{C} 13$ & $\mathrm{C} 14$ & $\mathrm{C} 15$ & $179.8(2)$ \\
\hline $\mathrm{H} 13$ & $\mathrm{C} 13$ & C14 & $\mathrm{H} 14$ & $-0.2(4)$ \\
\hline C12 & $\mathrm{C} 13$ & C14 & C15 & $-0.2(4)$ \\
\hline C12 & $C 13$ & C14 & $\mathrm{H} 14$ & $179.8(2)$ \\
\hline C6 & $\mathrm{C} 1$ & $\mathrm{C} 2$ & C3 & $0.6(4)$ \\
\hline C6 & $\mathrm{C} 1$ & $\mathrm{C} 2$ & $\mathrm{H} 2$ & $-179.4(3)$ \\
\hline $\mathrm{H} 1$ & $\mathrm{C} 1$ & $\mathrm{C} 2$ & C3 & $-179.4(3)$ \\
\hline $\mathrm{H} 1$ & C1 & $\mathrm{C} 2$ & $\mathrm{H} 2$ & $0.7(4)$ \\
\hline $\mathrm{H} 3$ & C3 & $\mathrm{C} 2$ & $\mathrm{C} 1$ & $179.6(3)$ \\
\hline $\mathrm{H} 3$ & C3 & $\mathrm{C} 2$ & $\mathrm{H} 2$ & $-0.4(5)$ \\
\hline $\mathrm{C} 4$ & $\mathrm{C} 3$ & $\mathrm{C} 2$ & $\mathrm{C} 1$ & $-0.4(4)$ \\
\hline $\mathrm{C} 4$ & $\mathrm{C} 3$ & $\mathrm{C} 2$ & $\mathrm{H} 2$ & $179.6(3)$ \\
\hline $\mathrm{H} 3$ & $\mathrm{C} 3$ & $\mathrm{C} 4$ & C5 & $179.6(3)$ \\
\hline $\mathrm{H} 3$ & $\mathrm{C} 3$ & $\mathrm{C} 4$ & $\mathrm{H} 4$ & $-0.5(5)$ \\
\hline $\mathrm{C} 2$ & $\mathrm{C} 3$ & $\mathrm{C} 4$ & C5 & $-0.4(4)$ \\
\hline $\mathrm{C} 2$ & $\mathrm{C} 3$ & $\mathrm{C} 4$ & $\mathrm{H} 4$ & $179.6(3)$ \\
\hline $\mathrm{O} 2$ & $\mathrm{C} 8$ & $\mathrm{C} 7$ & C6 & $116.9(2)$ \\
\hline $\mathrm{O} 2$ & $\mathrm{C} 8$ & $\mathrm{C} 7$ & $\mathrm{H} 7 \mathrm{~A}$ & $-123.6(2)$ \\
\hline $\mathrm{O} 2$ & $\mathrm{C} 8$ & $\mathrm{C} 7$ & $\mathrm{H} 7 \mathrm{~B}$ & $-2.5(3)$ \\
\hline C9 & $\mathrm{C} 8$ & $\mathrm{C} 7$ & $\mathrm{C} 6$ & $3.7(3)$ \\
\hline $\mathrm{C} 9$ & $\mathrm{C} 8$ & $\mathrm{C} 7$ & $\mathrm{H} 7 \mathrm{~A}$ & 123.2(2) \\
\hline C9 & $\mathrm{C} 8$ & $\mathrm{C} 7$ & $\mathrm{H} 7 \mathrm{~B}$ & $-115.8(2)$ \\
\hline $\mathrm{H} 8$ & C8 & $\mathrm{C} 7$ & C6 & $-118.4(2)$ \\
\hline $\mathrm{H} 8$ & C8 & C7 & $\mathrm{H} 7 \mathrm{~A}$ & $1.1(3)$ \\
\hline $\mathrm{H} 8$ & $\mathrm{C} 8$ & $\mathrm{C} 7$ & $\mathrm{H} 7 \mathrm{~B}$ & $122.2(2)$ \\
\hline
\end{tabular}


Table A11. Bond lengths $[\AA]$ for 9a

\begin{tabular}{llll}
\hline $\mathrm{H} 1 \mathrm{~A}$ & $\mathrm{C} 1$ & $\mathrm{H} 1 \mathrm{~B}$ & $109.4(7)$ \\
$\mathrm{H} 1 \mathrm{~A}$ & $\mathrm{C} 1$ & $\mathrm{H} 1 \mathrm{C}$ & $109.6(7)$ \\
$\mathrm{H} 1 \mathrm{~A}$ & $\mathrm{C} 1$ & $\mathrm{~N} 1$ & $109.5(6)$ \\
$\mathrm{H} 1 \mathrm{~B}$ & $\mathrm{C} 1$ & $\mathrm{H} 1 \mathrm{C}$ & $109.5(7)$ \\
$\mathrm{H} 1 \mathrm{~B}$ & $\mathrm{C} 1$ & $\mathrm{~N} 1$ & $109.4(6)$ \\
$\mathrm{H} 1 \mathrm{C}$ & $\mathrm{C} 1$ & $\mathrm{~N} 1$ & $109.5(6)$ \\
$\mathrm{H} 2 \mathrm{~A}$ & $\mathrm{C} 2$ & $\mathrm{H} 2 \mathrm{~B}$ & $109.5(7)$ \\
$\mathrm{H} 2 \mathrm{~A}$ & $\mathrm{C} 2$ & $\mathrm{H} 2 \mathrm{C}$ & $109.4(7)$ \\
$\mathrm{H} 2 \mathrm{~A}$ & $\mathrm{C} 2$ & $\mathrm{~N} 1$ & $109.4(7)$ \\
$\mathrm{H} 2 \mathrm{~B}$ & $\mathrm{C} 2$ & $\mathrm{H} 2 \mathrm{C}$ & $109.5(7)$ \\
$\mathrm{H} 2 \mathrm{~B}$ & $\mathrm{C} 2$ & $\mathrm{~N} 1$ & $109.5(7)$ \\
$\mathrm{H} 2 \mathrm{C}$ & $\mathrm{C} 2$ & $\mathrm{~N} 1$ & $109.4(7)$ \\
$\mathrm{H} 3 \mathrm{~A}$ & $\mathrm{C} 3$ & $\mathrm{H} 3 \mathrm{~B}$ & $107.8(6)$ \\
$\mathrm{H} 3 \mathrm{~A}$ & $\mathrm{C} 3$ & $\mathrm{C} 4$ & $109.1(6)$ \\
$\mathrm{H} 3 \mathrm{~A}$ & $\mathrm{C} 3$ & $\mathrm{~N} 1$ & $109.2(6)$ \\
$\mathrm{H} 3 \mathrm{~B}$ & $\mathrm{C} 3$ & $\mathrm{C} 4$ & $109.1(6)$ \\
$\mathrm{H} 3 \mathrm{~B}$ & $\mathrm{C} 3$ & $\mathrm{~N} 1$ & $109.1(6)$ \\
$\mathrm{C} 4$ & $\mathrm{C} 3$ & $\mathrm{~N} 1$ & $112.3(5)$ \\
$\mathrm{C} 3$ & $\mathrm{C} 4$ & $\mathrm{~N} 2$ & $112.7(6)$ \\
$\mathrm{C} 3$ & $\mathrm{C} 4$ & $\mathrm{O} 1$ & $119.5(6)$ \\
$\mathrm{N} 2$ & $\mathrm{C} 4$ & $\mathrm{O} 1$ & $127.8(6)$ \\
$\mathrm{C} 6$ & $\mathrm{C} 5$ & $\mathrm{C} 10$ & $117.2(6)$ \\
$\mathrm{C} 6$ & $\mathrm{C} 5$ & $\mathrm{~N} 2$ & $122.0(6)$ \\
$\mathrm{C} 10$ & $\mathrm{C} 5$ & $\mathrm{~N} 2$ & $120.7(5)$ \\
$\mathrm{C} 5$ & $\mathrm{C} 6$ & $\mathrm{H} 6$ & $119.1(6)$ \\
$\mathrm{C} 5$ & $\mathrm{C} 6$ & $\mathrm{C} 7$ & $121.7(6)$ \\
$\mathrm{H} 6$ & $\mathrm{C} 6$ & $\mathrm{C} 7$ & $119.2(6)$ \\
$\mathrm{C} 6$ & $\mathrm{C} 7$ & $\mathrm{H} 7$ & $119.6(7)$ \\
$\mathrm{C} 6$ & $\mathrm{C} 7$ & $\mathrm{C} 8$ & $120.8(6)$ \\
$\mathrm{H} 7$ & $\mathrm{C} 7$ & $\mathrm{C} 8$ & $119.6(7)$ \\
$\mathrm{C} 7$ & $\mathrm{C} 8$ & $\mathrm{H} 8$ & $120.4(7)$ \\
$\mathrm{C} 7$ & $\mathrm{C} 8$ & $\mathrm{C} 9$ & $119.0(6)$ \\
$\mathrm{H} 8$ & $\mathrm{C} 8$ & $\mathrm{C} 9$ & $120.6(7)$ \\
$\mathrm{C} 8$ & $\mathrm{C} 9$ & $\mathrm{H} 9$ & $119.7(6)$ \\
$\mathrm{C} 8$ & $\mathrm{C} 9$ & $\mathrm{C} 10$ & $120.7(6)$ \\
$\mathrm{H} 9$ & $\mathrm{C} 9$ & $\mathrm{C} 10$ & $119.7(6)$ \\
$\mathrm{C} 5$ & $\mathrm{C} 10$ & $\mathrm{C} 9$ & $120.6(6)$ \\
$\mathrm{C} 5$ & $\mathrm{C} 10$ & $\mathrm{C} 11$ & $122.3(6)$ \\
$\mathrm{C} 9$ & $\mathrm{C} 10$ & $\mathrm{C} 11$ & $117.1(6)$ \\
$\mathrm{C} 10$ & $\mathrm{C} 11$ & $\mathrm{~N} 3$ & $129.9(6)$ \\
$\mathrm{C} 10$ & $\mathrm{C} 11$ & $\mathrm{O} 2$ & $114.5(5)$ \\
& & & \\
& & & \\
& & &
\end{tabular}




$\begin{array}{llll}\text { N3 } & \text { C11 } & \text { O2 } & 115.6(6) \\ \text { H12A } & \text { C12 } & \text { H12B } & 108.7(6) \\ \text { H12A } & \text { C12 } & \text { C13 } & 110.5(6) \\ \text { H12A } & \text { C12 } & \text { O2 } & 110.4(6) \\ \text { H12B } & \mathrm{C} 12 & \mathrm{C} 13 & 110.5(6) \\ \mathrm{H} 12 \mathrm{~B} & \mathrm{C} 12 & \mathrm{O} 2 & 110.4(6) \\ \mathrm{C} 13 & \mathrm{C} 12 & \mathrm{O} 2 & 106.3(5) \\ \mathrm{C} 12 & \mathrm{C} 13 & \mathrm{C} 14 & 110.9(5) \\ \mathrm{C} 12 & \mathrm{C} 13 & \mathrm{C} 15 & 110.8(5) \\ \mathrm{C} 12 & \mathrm{C} 13 & \mathrm{~N} 3 & 100.9(5) \\ \mathrm{C} 14 & \mathrm{C} 13 & \mathrm{C} 15 & 112.5(5) \\ \mathrm{C} 14 & \mathrm{C} 13 & \mathrm{~N} 3 & 112.2(5) \\ \mathrm{C} 15 & \mathrm{C} 13 & \mathrm{~N} 3 & 109.1(5) \\ \mathrm{C} 13 & \mathrm{C} 14 & \mathrm{H} 14 \mathrm{~A} & 109.5(6) \\ \mathrm{C} 13 & \mathrm{C} 14 & \mathrm{H} 14 \mathrm{~B} & 109.4(6) \\ \mathrm{C} 13 & \mathrm{C} 14 & \mathrm{H} 14 \mathrm{C} & 109.5(6) \\ \mathrm{H} 14 \mathrm{~A} & \mathrm{C} 14 & \mathrm{H} 14 \mathrm{~B} & 109.5(6) \\ \mathrm{H} 14 \mathrm{~A} & \mathrm{C} 14 & \mathrm{H} 14 \mathrm{C} & 109.5(6) \\ \mathrm{H} 14 \mathrm{~B} & \mathrm{C} 14 & \mathrm{H} 14 \mathrm{C} & 109.4(6) \\ \mathrm{C} 13 & \mathrm{C} 15 & \mathrm{H} 15 \mathrm{~A} & 109.5(6) \\ \mathrm{C} 13 & \mathrm{C} 15 & \mathrm{H} 15 \mathrm{~B} & 109.5(6) \\ \mathrm{C} 13 & \mathrm{C} 15 & \mathrm{H} 15 \mathrm{C} & 109.5(6) \\ \mathrm{H} 15 \mathrm{~A} & \mathrm{C} 15 & \mathrm{H} 15 \mathrm{~B} & 109.3(6) \\ \mathrm{H} 15 \mathrm{~A} & \mathrm{C} 15 & \mathrm{H} 15 \mathrm{C} & 109.4(6) \\ \mathrm{H} 15 \mathrm{~B} & \mathrm{C} 15 & \mathrm{H} 15 \mathrm{C} & 109.6(6) \\ \mathrm{C} 1 & \mathrm{~N} 1 & \mathrm{C} 2 & 109.0(5) \\ \mathrm{C} 1 & \mathrm{~N} 1 & \mathrm{C} 3 & 110.8(5) \\ \mathrm{C} 1 & \mathrm{~N} 1 & \mathrm{Pd} 1 & 107.5(4) \\ \mathrm{C} 2 & \mathrm{~N} 1 & \mathrm{C} 3 & 108.3(5) \\ \mathrm{C} 2 & \mathrm{~N} 1 & \mathrm{Pd} 1 & 117.4(4) \\ \mathrm{C} 3 & \mathrm{~N} 1 & \mathrm{Pd} 1 & 103.7(4) \\ \mathrm{C} 4 & \mathrm{~N} 2 & \mathrm{C} 5 & 120.0(6) \\ \mathrm{C} 4 & \mathrm{~N} 2 & \mathrm{Pd} 1 & 115.2(4) \\ \mathrm{C} 5 & \mathrm{~N} 2 & \mathrm{Pd} 1 & 124.7(4) \\ \mathrm{C} 11 & \mathrm{~N} 3 & \mathrm{C} 13 & 108.7(5) \\ \mathrm{C} 11 & \mathrm{~N} 3 & \mathrm{Pd} 1 & 121.3(4) \\ \mathrm{C} 13 & \mathrm{~N} 3 & \mathrm{Pd} 1 & 129.9(4) \\ \mathrm{C} 11 & \mathrm{O} 2 & \mathrm{C} 12 & 106.1(5) \\ \mathrm{N} 1 & \mathrm{Pd} 1 & \mathrm{~N} 2 & 80.7(2) \\ \mathrm{N} 1 & \mathrm{Pd} 1 & \mathrm{~N} 3 & 171.2(2) \\ \mathrm{N} 1 & \mathrm{Pd} 1 & \mathrm{Cl} 1 & 92.5(1) \\ \mathrm{N} 2 & \mathrm{Pd} 1 & \mathrm{~N} 3 & 90.7(2) \\ \mathrm{N} 2 & \mathrm{Pd} 1 & \mathrm{Cl} 1 & 172.5(2) \\ & & & \end{array}$




\begin{tabular}{|c|c|c|c|}
\hline N3 & $\mathrm{Pd} 1$ & $\mathrm{Cl} 1$ & $96.1(1)$ \\
\hline H16A & C16 & $\mathrm{H} 16 \mathrm{~B}$ & $109.4(7)$ \\
\hline H16A & C16 & $\mathrm{H} 16 \mathrm{C}$ & $109.6(7)$ \\
\hline H16A & C16 & N4 & $109.5(6)$ \\
\hline H16B & C16 & $\mathrm{H} 16 \mathrm{C}$ & $109.4(7)$ \\
\hline H16B & C16 & N4 & $109.5(6)$ \\
\hline H16C & C16 & N4 & $109.5(6)$ \\
\hline H17A & C17 & $\mathrm{H} 17 \mathrm{~B}$ & $109.4(6)$ \\
\hline H17A & C17 & $\mathrm{H} 17 \mathrm{C}$ & $109.5(6)$ \\
\hline H17A & C17 & N4 & $109.4(6)$ \\
\hline H17B & C17 & $\mathrm{H} 17 \mathrm{C}$ & $109.5(6)$ \\
\hline H17B & C17 & N4 & $109.4(6)$ \\
\hline $\mathrm{H} 17 \mathrm{C}$ & C17 & N4 & $109.5(6)$ \\
\hline H18A & C18 & H18B & $107.9(6)$ \\
\hline H18A & C18 & C19 & $109.0(6)$ \\
\hline H18A & C18 & N4 & $109.1(6)$ \\
\hline H18B & C18 & C19 & $109.1(6)$ \\
\hline H18B & C18 & N4 & $109.0(6)$ \\
\hline C19 & C18 & N4 & $112.6(5)$ \\
\hline C18 & C19 & N5 & $112.6(5)$ \\
\hline C18 & C19 & $\mathrm{O} 3$ & $119.5(6)$ \\
\hline N5 & C19 & O3 & $127.8(6)$ \\
\hline $\mathrm{C} 21$ & C20 & C25 & $117.4(6)$ \\
\hline C21 & C20 & N5 & $121.6(6)$ \\
\hline $\mathrm{C} 25$ & C20 & N5 & $121.0(5)$ \\
\hline C20 & C21 & $\mathrm{H} 21$ & 119.2(7) \\
\hline C20 & C21 & C22 & $121.7(6)$ \\
\hline $\mathrm{H} 21$ & C21 & C22 & $119.1(7)$ \\
\hline C21 & C22 & $\mathrm{H} 22$ & $119.5(7)$ \\
\hline C21 & C22 & C23 & 121.1(7) \\
\hline H22 & C22 & C23 & $119.4(7)$ \\
\hline $\mathrm{C} 22$ & C23 & $\mathrm{H} 23$ & $120.6(7)$ \\
\hline $\mathrm{C} 22$ & C23 & C24 & $118.7(6)$ \\
\hline $\mathrm{H} 23$ & C23 & C24 & $120.6(7)$ \\
\hline C23 & C24 & $\mathrm{H} 24$ & 119.5(6) \\
\hline C23 & C24 & C25 & $120.9(6)$ \\
\hline $\mathrm{H} 24$ & C24 & C25 & 119.5(6) \\
\hline C20 & C25 & C24 & $120.0(6)$ \\
\hline C20 & C25 & C26 & $122.9(5)$ \\
\hline C24 & $\mathrm{C} 25$ & C26 & $117.0(5)$ \\
\hline C25 & C26 & N6 & $129.8(5)$ \\
\hline $\mathrm{C} 25$ & C26 & $\mathrm{O} 4$ & $114.1(5)$ \\
\hline N6 & C26 & O4 & $116.2(5)$ \\
\hline
\end{tabular}




\begin{tabular}{|c|c|c|c|}
\hline $\mathrm{H} 27 \mathrm{~A}$ & $\mathrm{C} 27$ & $\mathrm{H} 27 \mathrm{~B}$ & $108.7(6)$ \\
\hline H27A & $\mathrm{C} 27$ & C28 & $110.7(6)$ \\
\hline $\mathrm{H} 27 \mathrm{~A}$ & $\mathrm{C} 27$ & O4 & $110.7(6)$ \\
\hline H27B & $\mathrm{C} 27$ & C28 & $110.7(6)$ \\
\hline H27B & $\mathrm{C} 27$ & O4 & $110.6(6)$ \\
\hline C28 & $\mathrm{C} 27$ & O4 & $105.4(5)$ \\
\hline $\mathrm{C} 27$ & $\mathrm{C} 28$ & C29 & $110.4(5)$ \\
\hline $\mathrm{C} 27$ & $\mathrm{C} 28$ & C30 & $110.0(5)$ \\
\hline $\mathrm{C} 27$ & $\mathrm{C} 28$ & N6 & $100.7(5)$ \\
\hline C29 & $\mathrm{C} 28$ & C30 & $114.0(5)$ \\
\hline C29 & $\mathrm{C} 28$ & N6 & $111.7(5)$ \\
\hline C30 & $\mathrm{C} 28$ & N6 & $109.4(5)$ \\
\hline C28 & C29 & H29A & $109.5(6)$ \\
\hline C28 & C29 & H29B & $109.5(6)$ \\
\hline C28 & C29 & $\mathrm{H} 29 \mathrm{C}$ & $109.5(6)$ \\
\hline H29A & C29 & H29B & $109.4(6)$ \\
\hline H29A & C29 & $\mathrm{H} 29 \mathrm{C}$ & $109.5(6)$ \\
\hline H29B & C29 & $\mathrm{H} 29 \mathrm{C}$ & $109.5(6)$ \\
\hline C28 & C30 & H30A & $109.5(6)$ \\
\hline C28 & C30 & H30B & $109.5(6)$ \\
\hline C28 & C30 & $\mathrm{H} 30 \mathrm{C}$ & $109.5(6)$ \\
\hline H30A & C30 & H30B & $109.4(7)$ \\
\hline H30A & C30 & $\mathrm{H} 30 \mathrm{C}$ & $109.5(7)$ \\
\hline H30B & C30 & $\mathrm{H} 30 \mathrm{C}$ & $109.4(7)$ \\
\hline C16 & N4 & C17 & $108.8(5)$ \\
\hline C16 & N4 & C18 & $107.7(5)$ \\
\hline C16 & N4 & $\mathrm{Pd} 2$ & $118.5(4)$ \\
\hline C17 & N4 & C18 & $110.0(5)$ \\
\hline C17 & N4 & $\mathrm{Pd} 2$ & $108.1(4)$ \\
\hline C18 & N4 & $\mathrm{Pd} 2$ & $103.4(4)$ \\
\hline C19 & N5 & C20 & $120.5(5)$ \\
\hline C19 & N5 & $\mathrm{Pd} 2$ & $113.4(4)$ \\
\hline C20 & N5 & $\mathrm{Pd} 2$ & $126.0(4)$ \\
\hline C26 & N6 & C28 & $108.1(5)$ \\
\hline C26 & N6 & $\mathrm{Pd} 2$ & $123.2(4)$ \\
\hline C28 & N6 & $\mathrm{Pd} 2$ & $128.6(4)$ \\
\hline C26 & O4 & $\mathrm{C} 27$ & $106.6(5)$ \\
\hline N4 & $\mathrm{Pd} 2$ & N5 & $81.6(2)$ \\
\hline N4 & $\mathrm{Pd} 2$ & N6 & $172.0(2)$ \\
\hline N4 & $\mathrm{Pd} 2$ & $\mathrm{Cl} 2$ & $91.2(1)$ \\
\hline N5 & $\mathrm{Pd} 2$ & N6 & $90.4(2)$ \\
\hline N5 & $\mathrm{Pd} 2$ & $\mathrm{Cl} 2$ & $172.5(1)$ \\
\hline N6 & $\mathrm{Pd} 2$ & $\mathrm{Cl} 2$ & $96.8(1)$ \\
\hline
\end{tabular}


Table A12. Angles $\left[{ }^{\circ}\right]$ for $9 a$

\begin{tabular}{llll}
\hline $\mathrm{H} 1 \mathrm{~A}$ & $\mathrm{C} 1$ & $\mathrm{H} 1 \mathrm{~B}$ & $109.4(7)$ \\
$\mathrm{H} 1 \mathrm{~A}$ & $\mathrm{C} 1$ & $\mathrm{H} 1 \mathrm{C}$ & $109.6(7)$ \\
$\mathrm{H} 1 \mathrm{~A}$ & $\mathrm{C} 1$ & $\mathrm{~N} 1$ & $109.5(6)$ \\
$\mathrm{H} 1 \mathrm{~B}$ & $\mathrm{C} 1$ & $\mathrm{H} 1 \mathrm{C}$ & $109.5(7)$ \\
$\mathrm{H} 1 \mathrm{~B}$ & $\mathrm{C} 1$ & $\mathrm{~N} 1$ & $109.4(6)$ \\
$\mathrm{H} 1 \mathrm{C}$ & $\mathrm{C} 1$ & $\mathrm{~N} 1$ & $109.5(6)$ \\
$\mathrm{H} 2 \mathrm{~A}$ & $\mathrm{C} 2$ & $\mathrm{H} 2 \mathrm{~B}$ & $109.5(7)$ \\
$\mathrm{H} 2 \mathrm{~A}$ & $\mathrm{C} 2$ & $\mathrm{H} 2 \mathrm{C}$ & $109.4(7)$ \\
$\mathrm{H} 2 \mathrm{~A}$ & $\mathrm{C} 2$ & $\mathrm{~N} 1$ & $109.4(7)$ \\
$\mathrm{H} 2 \mathrm{~B}$ & $\mathrm{C} 2$ & $\mathrm{H} 2 \mathrm{C}$ & $109.5(7)$ \\
$\mathrm{H} 2 \mathrm{~B}$ & $\mathrm{C} 2$ & $\mathrm{~N} 1$ & $109.5(7)$ \\
$\mathrm{H} 2 \mathrm{C}$ & $\mathrm{C} 2$ & $\mathrm{~N} 1$ & $109.4(7)$ \\
$\mathrm{H} 3 \mathrm{~A}$ & $\mathrm{C} 3$ & $\mathrm{H} 3 \mathrm{~B}$ & $107.8(6)$ \\
$\mathrm{H} 3 \mathrm{~A}$ & $\mathrm{C} 3$ & $\mathrm{C} 4$ & $109.1(6)$ \\
$\mathrm{H} 3 \mathrm{~A}$ & $\mathrm{C} 3$ & $\mathrm{~N} 1$ & $109.2(6)$ \\
$\mathrm{H} 3 \mathrm{~B}$ & $\mathrm{C} 3$ & $\mathrm{C} 4$ & $109.1(6)$ \\
$\mathrm{H} 3 \mathrm{~B}$ & $\mathrm{C} 3$ & $\mathrm{~N} 1$ & $109.1(6)$ \\
$\mathrm{C} 4$ & $\mathrm{C} 3$ & $\mathrm{~N} 1$ & $112.3(5)$ \\
$\mathrm{C} 3$ & $\mathrm{C} 4$ & $\mathrm{~N} 2$ & $112.7(6)$ \\
$\mathrm{C} 3$ & $\mathrm{C} 4$ & $\mathrm{O} 1$ & $119.5(6)$ \\
$\mathrm{N} 2$ & $\mathrm{C} 4$ & $\mathrm{O} 1$ & $127.8(6)$ \\
$\mathrm{C} 6$ & $\mathrm{C} 5$ & $\mathrm{C} 10$ & $117.2(6)$ \\
$\mathrm{C} 6$ & $\mathrm{C} 5$ & $\mathrm{~N} 2$ & $122.0(6)$ \\
$\mathrm{C} 10$ & $\mathrm{C} 5$ & $\mathrm{~N} 2$ & $120.7(5)$ \\
$\mathrm{C} 5$ & $\mathrm{C} 6$ & $\mathrm{H} 6$ & $119.1(6)$ \\
$\mathrm{C} 5$ & $\mathrm{C} 6$ & $\mathrm{C} 7$ & $121.7(6)$ \\
$\mathrm{H} 6$ & $\mathrm{C} 6$ & $\mathrm{C} 7$ & $119.2(6)$ \\
$\mathrm{C} 6$ & $\mathrm{C} 7$ & $\mathrm{H} 7$ & $119.6(7)$ \\
$\mathrm{C} 6$ & $\mathrm{C} 7$ & $\mathrm{C} 8$ & $120.8(6)$ \\
$\mathrm{H} 7$ & $\mathrm{C} 7$ & $\mathrm{C} 8$ & $119.6(7)$ \\
$\mathrm{C} 7$ & $\mathrm{C} 8$ & $\mathrm{H} 8$ & $120.4(7)$ \\
$\mathrm{C} 7$ & $\mathrm{C} 8$ & $\mathrm{C} 9$ & $119.0(6)$ \\
$\mathrm{H} 8$ & $\mathrm{C} 8$ & $\mathrm{C} 9$ & $120.6(7)$ \\
$\mathrm{C} 8$ & $\mathrm{C} 9$ & $\mathrm{H} 9$ & $119.7(6)$ \\
$\mathrm{C} 8$ & $\mathrm{C} 9$ & $\mathrm{C} 10$ & $120.7(6)$ \\
$\mathrm{H} 9$ & $\mathrm{C} 9$ & $\mathrm{C} 10$ & $119.7(6)$ \\
$\mathrm{C} 5$ & $\mathrm{C} 10$ & $\mathrm{C} 9$ & $120.6(6)$ \\
$\mathrm{C} 5$ & $\mathrm{C} 10$ & $\mathrm{C} 11$ & $122.3(6)$ \\
$\mathrm{C} 9$ & $\mathrm{C} 10$ & $\mathrm{C} 11$ & $117.1(6)$ \\
$\mathrm{C} 10$ & $\mathrm{C} 11$ & $\mathrm{~N} 3$ & $129.9(6)$ \\
$\mathrm{C} 10$ & $\mathrm{C} 11$ & $\mathrm{O} 2$ & $114.5(5)$ \\
& & & \\
& & &
\end{tabular}




$\begin{array}{llll}\text { N3 } & \text { C11 } & \text { O2 } & 115.6(6) \\ \text { H12A } & \text { C12 } & \text { H12B } & 108.7(6) \\ \text { H12A } & \text { C12 } & \text { C13 } & 110.5(6) \\ \text { H12A } & \text { C12 } & \text { O2 } & 110.4(6) \\ \text { H12B } & \mathrm{C} 12 & \mathrm{C} 13 & 110.5(6) \\ \mathrm{H} 12 \mathrm{~B} & \mathrm{C} 12 & \mathrm{O} 2 & 110.4(6) \\ \mathrm{C} 13 & \mathrm{C} 12 & \mathrm{O} 2 & 106.3(5) \\ \mathrm{C} 12 & \mathrm{C} 13 & \mathrm{C} 14 & 110.9(5) \\ \mathrm{C} 12 & \mathrm{C} 13 & \mathrm{C} 15 & 110.8(5) \\ \mathrm{C} 12 & \mathrm{C} 13 & \mathrm{~N} 3 & 100.9(5) \\ \mathrm{C} 14 & \mathrm{C} 13 & \mathrm{C} 15 & 112.5(5) \\ \mathrm{C} 14 & \mathrm{C} 13 & \mathrm{~N} 3 & 112.2(5) \\ \mathrm{C} 15 & \mathrm{C} 13 & \mathrm{~N} 3 & 109.1(5) \\ \mathrm{C} 13 & \mathrm{C} 14 & \mathrm{H} 14 \mathrm{~A} & 109.5(6) \\ \mathrm{C} 13 & \mathrm{C} 14 & \mathrm{H} 14 \mathrm{~B} & 109.4(6) \\ \mathrm{C} 13 & \mathrm{C} 14 & \mathrm{H} 14 \mathrm{C} & 109.5(6) \\ \mathrm{H} 14 \mathrm{~A} & \mathrm{C} 14 & \mathrm{H} 14 \mathrm{~B} & 109.5(6) \\ \mathrm{H} 14 \mathrm{~A} & \mathrm{C} 14 & \mathrm{H} 14 \mathrm{C} & 109.5(6) \\ \mathrm{H} 14 \mathrm{~B} & \mathrm{C} 14 & \mathrm{H} 14 \mathrm{C} & 109.4(6) \\ \mathrm{C} 13 & \mathrm{C} 15 & \mathrm{H} 15 \mathrm{~A} & 109.5(6) \\ \mathrm{C} 13 & \mathrm{C} 15 & \mathrm{H} 15 \mathrm{~B} & 109.5(6) \\ \mathrm{C} 13 & \mathrm{C} 15 & \mathrm{H} 15 \mathrm{C} & 109.5(6) \\ \mathrm{H} 15 \mathrm{~A} & \mathrm{C} 15 & \mathrm{H} 15 \mathrm{~B} & 109.3(6) \\ \mathrm{H} 15 \mathrm{~A} & \mathrm{C} 15 & \mathrm{H} 15 \mathrm{C} & 109.4(6) \\ \mathrm{H} 15 \mathrm{~B} & \mathrm{C} 15 & \mathrm{H} 15 \mathrm{C} & 109.6(6) \\ \mathrm{C} 1 & \mathrm{~N} 1 & \mathrm{C} 2 & 109.0(5) \\ \mathrm{C} 1 & \mathrm{~N} 1 & \mathrm{C} 3 & 110.8(5) \\ \mathrm{C} 1 & \mathrm{~N} 1 & \mathrm{Pd} 1 & 107.5(4) \\ \mathrm{C} 2 & \mathrm{~N} 1 & \mathrm{C} 3 & 108.3(5) \\ \mathrm{C} 2 & \mathrm{~N} 1 & \mathrm{Pd} 1 & 117.4(4) \\ \mathrm{C} 3 & \mathrm{~N} 1 & \mathrm{Pd} 1 & 103.7(4) \\ \mathrm{C} 4 & \mathrm{~N} 2 & \mathrm{C} 5 & 120.0(6) \\ \mathrm{C} 4 & \mathrm{~N} 2 & \mathrm{Pd} 1 & 115.2(4) \\ \mathrm{C} 5 & \mathrm{~N} 2 & \mathrm{Pd} 1 & 124.7(4) \\ \mathrm{C} 11 & \mathrm{~N} 3 & \mathrm{C} 13 & 108.7(5) \\ \mathrm{C} 11 & \mathrm{~N} 3 & \mathrm{Pd} 1 & 121.3(4) \\ \mathrm{C} 13 & \mathrm{~N} 3 & \mathrm{Pd} 1 & 129.9(4) \\ \mathrm{C} 11 & \mathrm{O} 2 & \mathrm{C} 12 & 106.1(5) \\ \mathrm{N} 1 & \mathrm{Pd} 1 & \mathrm{~N} 2 & 80.7(2) \\ \mathrm{N} 1 & \mathrm{Pd} 1 & \mathrm{~N} 3 & 171.2(2) \\ \mathrm{N} 1 & \mathrm{Pd} 1 & \mathrm{Cl} 1 & 92.5(1) \\ \mathrm{N} 2 & \mathrm{Pd} 1 & \mathrm{~N} 3 & 90.7(2) \\ \mathrm{N} 2 & \mathrm{Pd} 1 & \mathrm{Cl} 1 & 172.5(2) \\ & & & \end{array}$




\begin{tabular}{|c|c|c|c|}
\hline N3 & $\mathrm{Pd} 1$ & $\mathrm{Cl} 1$ & $96.1(1)$ \\
\hline H16A & C16 & $\mathrm{H} 16 \mathrm{~B}$ & $109.4(7)$ \\
\hline H16A & C16 & $\mathrm{H} 16 \mathrm{C}$ & $109.6(7)$ \\
\hline H16A & C16 & N4 & $109.5(6)$ \\
\hline H16B & C16 & $\mathrm{H} 16 \mathrm{C}$ & $109.4(7)$ \\
\hline H16B & C16 & N4 & $109.5(6)$ \\
\hline H16C & C16 & N4 & $109.5(6)$ \\
\hline H17A & C17 & $\mathrm{H} 17 \mathrm{~B}$ & $109.4(6)$ \\
\hline H17A & C17 & $\mathrm{H} 17 \mathrm{C}$ & $109.5(6)$ \\
\hline H17A & C17 & N4 & $109.4(6)$ \\
\hline H17B & C17 & $\mathrm{H} 17 \mathrm{C}$ & $109.5(6)$ \\
\hline H17B & C17 & N4 & $109.4(6)$ \\
\hline $\mathrm{H} 17 \mathrm{C}$ & C17 & N4 & $109.5(6)$ \\
\hline H18A & C18 & H18B & $107.9(6)$ \\
\hline H18A & C18 & C19 & $109.0(6)$ \\
\hline H18A & C18 & N4 & $109.1(6)$ \\
\hline H18B & C18 & C19 & $109.1(6)$ \\
\hline H18B & C18 & N4 & $109.0(6)$ \\
\hline C19 & C18 & N4 & $112.6(5)$ \\
\hline C18 & C19 & N5 & $112.6(5)$ \\
\hline C18 & C19 & $\mathrm{O} 3$ & $119.5(6)$ \\
\hline N5 & C19 & O3 & $127.8(6)$ \\
\hline $\mathrm{C} 21$ & C20 & C25 & $117.4(6)$ \\
\hline C21 & C20 & N5 & $121.6(6)$ \\
\hline $\mathrm{C} 25$ & C20 & N5 & $121.0(5)$ \\
\hline C20 & C21 & $\mathrm{H} 21$ & 119.2(7) \\
\hline C20 & C21 & C22 & $121.7(6)$ \\
\hline $\mathrm{H} 21$ & C21 & C22 & $119.1(7)$ \\
\hline C21 & C22 & $\mathrm{H} 22$ & $119.5(7)$ \\
\hline C21 & C22 & C23 & 121.1(7) \\
\hline H22 & C22 & C23 & $119.4(7)$ \\
\hline $\mathrm{C} 22$ & C23 & $\mathrm{H} 23$ & $120.6(7)$ \\
\hline $\mathrm{C} 22$ & C23 & C24 & $118.7(6)$ \\
\hline $\mathrm{H} 23$ & C23 & C24 & $120.6(7)$ \\
\hline C23 & C24 & $\mathrm{H} 24$ & 119.5(6) \\
\hline C23 & C24 & C25 & $120.9(6)$ \\
\hline $\mathrm{H} 24$ & C24 & C25 & 119.5(6) \\
\hline C20 & C25 & C24 & $120.0(6)$ \\
\hline C20 & C25 & C26 & $122.9(5)$ \\
\hline C24 & $\mathrm{C} 25$ & C26 & $117.0(5)$ \\
\hline C25 & C26 & N6 & $129.8(5)$ \\
\hline $\mathrm{C} 25$ & C26 & $\mathrm{O} 4$ & $114.1(5)$ \\
\hline N6 & C26 & O4 & $116.2(5)$ \\
\hline
\end{tabular}




\begin{tabular}{|c|c|c|c|}
\hline $\mathrm{H} 27 \mathrm{~A}$ & $\mathrm{C} 27$ & $\mathrm{H} 27 \mathrm{~B}$ & $108.7(6)$ \\
\hline H27A & $\mathrm{C} 27$ & C28 & $110.7(6)$ \\
\hline $\mathrm{H} 27 \mathrm{~A}$ & $\mathrm{C} 27$ & O4 & $110.7(6)$ \\
\hline H27B & $\mathrm{C} 27$ & C28 & $110.7(6)$ \\
\hline H27B & $\mathrm{C} 27$ & O4 & $110.6(6)$ \\
\hline C28 & $\mathrm{C} 27$ & O4 & $105.4(5)$ \\
\hline $\mathrm{C} 27$ & $\mathrm{C} 28$ & C29 & $110.4(5)$ \\
\hline $\mathrm{C} 27$ & $\mathrm{C} 28$ & C30 & $110.0(5)$ \\
\hline $\mathrm{C} 27$ & $\mathrm{C} 28$ & N6 & $100.7(5)$ \\
\hline C29 & $\mathrm{C} 28$ & C30 & $114.0(5)$ \\
\hline C29 & $\mathrm{C} 28$ & N6 & $111.7(5)$ \\
\hline C30 & $\mathrm{C} 28$ & N6 & $109.4(5)$ \\
\hline C28 & C29 & H29A & $109.5(6)$ \\
\hline C28 & C29 & H29B & $109.5(6)$ \\
\hline C28 & C29 & $\mathrm{H} 29 \mathrm{C}$ & $109.5(6)$ \\
\hline H29A & C29 & H29B & $109.4(6)$ \\
\hline H29A & C29 & $\mathrm{H} 29 \mathrm{C}$ & $109.5(6)$ \\
\hline H29B & C29 & $\mathrm{H} 29 \mathrm{C}$ & $109.5(6)$ \\
\hline C28 & C30 & H30A & $109.5(6)$ \\
\hline C28 & C30 & H30B & $109.5(6)$ \\
\hline C28 & C30 & $\mathrm{H} 30 \mathrm{C}$ & $109.5(6)$ \\
\hline H30A & C30 & H30B & $109.4(7)$ \\
\hline H30A & C30 & $\mathrm{H} 30 \mathrm{C}$ & $109.5(7)$ \\
\hline H30B & C30 & $\mathrm{H} 30 \mathrm{C}$ & $109.4(7)$ \\
\hline C16 & N4 & C17 & $108.8(5)$ \\
\hline C16 & N4 & C18 & $107.7(5)$ \\
\hline C16 & N4 & $\mathrm{Pd} 2$ & $118.5(4)$ \\
\hline C17 & N4 & C18 & $110.0(5)$ \\
\hline C17 & N4 & $\mathrm{Pd} 2$ & $108.1(4)$ \\
\hline C18 & N4 & $\mathrm{Pd} 2$ & $103.4(4)$ \\
\hline C19 & N5 & C20 & $120.5(5)$ \\
\hline C19 & N5 & $\mathrm{Pd} 2$ & $113.4(4)$ \\
\hline C20 & N5 & $\mathrm{Pd} 2$ & $126.0(4)$ \\
\hline C26 & N6 & C28 & $108.1(5)$ \\
\hline C26 & N6 & $\mathrm{Pd} 2$ & $123.2(4)$ \\
\hline C28 & N6 & $\mathrm{Pd} 2$ & $128.6(4)$ \\
\hline C26 & O4 & $\mathrm{C} 27$ & $106.6(5)$ \\
\hline N4 & $\mathrm{Pd} 2$ & N5 & $81.6(2)$ \\
\hline N4 & $\mathrm{Pd} 2$ & N6 & $172.0(2)$ \\
\hline N4 & $\mathrm{Pd} 2$ & $\mathrm{Cl} 2$ & $91.2(1)$ \\
\hline N5 & $\mathrm{Pd} 2$ & N6 & $90.4(2)$ \\
\hline N5 & $\mathrm{Pd} 2$ & $\mathrm{Cl} 2$ & $172.5(1)$ \\
\hline N6 & $\mathrm{Pd} 2$ & $\mathrm{Cl} 2$ & $96.8(1)$ \\
\hline
\end{tabular}


Table A13. Torsion angles $\left[{ }^{\circ}\right]$ for $9 a$

\begin{tabular}{|c|c|c|c|c|}
\hline $\mathrm{H} 1 \mathrm{~A}$ & C1 & N1 & $\mathrm{C} 2$ & $-63.4(7)$ \\
\hline $\mathrm{H} 1 \mathrm{~A}$ & C1 & N1 & C3 & $177.4(6)$ \\
\hline $\mathrm{H} 1 \mathrm{~A}$ & C1 & N1 & $\mathrm{Pd} 1$ & $64.8(6)$ \\
\hline $\mathrm{H} 1 \mathrm{~B}$ & $\mathrm{C} 1$ & N1 & $\mathrm{C} 2$ & $176.7(6)$ \\
\hline H1B & C1 & N1 & C3 & $57.5(8)$ \\
\hline H1B & C1 & N1 & $\mathrm{Pd} 1$ & $-55.1(7)$ \\
\hline $\mathrm{H} 1 \mathrm{C}$ & C1 & N1 & C2 & $56.7(8)$ \\
\hline $\mathrm{H} 1 \mathrm{C}$ & C1 & N1 & C3 & $-62.4(7)$ \\
\hline $\mathrm{H} 1 \mathrm{C}$ & C1 & N1 & $\mathrm{Pd} 1$ & $-175.1(5)$ \\
\hline $\mathrm{H} 2 \mathrm{~A}$ & C2 & N1 & C1 & $61.6(8)$ \\
\hline $\mathrm{H} 2 \mathrm{~A}$ & C2 & N1 & C3 & $-177.7(6)$ \\
\hline $\mathrm{H} 2 \mathrm{~A}$ & $\mathrm{C} 2$ & N1 & $\mathrm{Pd} 1$ & $-60.8(7)$ \\
\hline H2B & $\mathrm{C} 2$ & N1 & $\mathrm{C} 1$ & $-58.4(8)$ \\
\hline H2B & $\mathrm{C} 2$ & N1 & C3 & $62.2(8)$ \\
\hline H2B & C2 & N1 & $\mathrm{Pd} 1$ & 179.1(5) \\
\hline $\mathrm{H} 2 \mathrm{C}$ & C2 & N1 & C1 & $-178.5(6)$ \\
\hline $\mathrm{H} 2 \mathrm{C}$ & C2 & N1 & C3 & $-57.8(8)$ \\
\hline $\mathrm{H} 2 \mathrm{C}$ & C2 & N1 & $\mathrm{Pd} 1$ & $59.0(7)$ \\
\hline H3A & C3 & C4 & N2 & 101.3(7) \\
\hline $\mathrm{H} 3 \mathrm{~A}$ & C3 & C4 & 01 & $-76.9(8)$ \\
\hline H3B & C3 & C4 & N2 & $-141.1(6)$ \\
\hline H3B & C3 & C4 & 01 & $40.7(9)$ \\
\hline N1 & C3 & C4 & N2 & $-19.9(8)$ \\
\hline N1 & C3 & C4 & 01 & $161.9(6)$ \\
\hline $\mathrm{H} 3 \mathrm{~A}$ & C3 & N1 & C1 & $161.4(6)$ \\
\hline $\mathrm{H} 3 \mathrm{~A}$ & C3 & N1 & C2 & $41.9(7)$ \\
\hline $\mathrm{H} 3 \mathrm{~A}$ & C3 & N1 & $\mathrm{Pd} 1$ & $-83.5(6)$ \\
\hline H3B & C3 & N1 & C1 & $43.7(7)$ \\
\hline H3B & C3 & N1 & C2 & $-75.7(7)$ \\
\hline H3B & C3 & N1 & $\mathrm{Pd} 1$ & $158.8(5)$ \\
\hline C4 & C3 & N1 & C1 & $-77.4(7)$ \\
\hline C4 & C3 & N1 & C2 & $163.1(5)$ \\
\hline C4 & C3 & N1 & $\mathrm{Pd} 1$ & $37.7(6)$ \\
\hline C3 & $\mathrm{C} 4$ & N2 & C5 & $164.9(6)$ \\
\hline C3 & $\mathrm{C} 4$ & N2 & $\mathrm{Pd} 1$ & $-10.9(7)$ \\
\hline O1 & $\mathrm{C} 4$ & N2 & $\mathrm{C} 5$ & $-17(1)$ \\
\hline 01 & C4 & N2 & $\mathrm{Pd} 1$ & $167.2(6)$ \\
\hline C10 & C5 & C6 & $\mathrm{H} 6$ & $-178.4(6)$ \\
\hline C10 & C5 & C6 & $\mathrm{C} 7$ & $1.7(9)$ \\
\hline N2 & C5 & C6 & $\mathrm{H} 6$ & $4(1)$ \\
\hline N2 & C5 & C6 & C7 & $-175.9(6)$ \\
\hline
\end{tabular}




\begin{tabular}{|c|c|c|c|c|}
\hline C6 & C5 & C10 & C9 & $-0.7(9)$ \\
\hline C6 & C5 & C10 & C11 & $179.9(6)$ \\
\hline N2 & C5 & C10 & C9 & $176.8(6)$ \\
\hline N2 & C5 & C10 & C11 & $-2.5(9)$ \\
\hline C6 & C5 & $\mathrm{N} 2$ & C4 & $-26.7(9)$ \\
\hline C6 & C5 & N2 & $\mathrm{Pd} 1$ & $148.6(5)$ \\
\hline C10 & C5 & $\mathrm{N} 2$ & C4 & $155.8(6)$ \\
\hline C10 & C5 & $\mathrm{N} 2$ & $\mathrm{Pd} 1$ & $-28.9(8)$ \\
\hline C5 & C6 & $\mathrm{C} 7$ & $\mathrm{H} 7$ & $177.8(7)$ \\
\hline C5 & C6 & C7 & C8 & $-2(1)$ \\
\hline $\mathrm{H} 6$ & C6 & C7 & $\mathrm{H} 7$ & $-2(1)$ \\
\hline $\mathrm{H} 6$ & C6 & C7 & C8 & $177.9(7)$ \\
\hline C6 & $\mathrm{C} 7$ & $\mathrm{C} 8$ & $\mathrm{H} 8$ & $-178.4(7)$ \\
\hline C6 & $\mathrm{C} 7$ & $\mathrm{C} 8$ & C9 & $2(1)$ \\
\hline $\mathrm{H} 7$ & $\mathrm{C} 7$ & $\mathrm{C} 8$ & $\mathrm{H} 8$ & $2(1)$ \\
\hline $\mathrm{H} 7$ & $\mathrm{C} 7$ & C8 & C9 & $-178.3(7)$ \\
\hline $\mathrm{C} 7$ & C8 & C9 & H9 & 179.2(7) \\
\hline C7 & C8 & C9 & C10 & $-1(1)$ \\
\hline $\mathrm{H} 8$ & $\mathrm{C} 8$ & C9 & $\mathrm{H} 9$ & $-1(1)$ \\
\hline $\mathrm{H} 8$ & $\mathrm{C} 8$ & C9 & $\mathrm{C} 10$ & $179.3(6)$ \\
\hline C8 & C9 & C10 & C5 & $0(1)$ \\
\hline $\mathrm{C} 8$ & C9 & $\mathrm{C} 10$ & C11 & $179.6(6)$ \\
\hline $\mathrm{H} 9$ & C9 & C10 & C5 & $-179.7(6)$ \\
\hline $\mathrm{H} 9$ & C9 & C10 & C11 & $-0(1)$ \\
\hline C5 & C10 & C11 & N3 & $23(1)$ \\
\hline C5 & C10 & C11 & $\mathrm{O} 2$ & $-158.4(6)$ \\
\hline C9 & C10 & C11 & N3 & $-155.9(7)$ \\
\hline C9 & $\mathrm{C} 10$ & C11 & $\mathrm{O} 2$ & $22.3(8)$ \\
\hline C10 & C11 & N3 & $\mathrm{C} 13$ & $173.9(6)$ \\
\hline C10 & C11 & N3 & Pd1 & $-8.9(9)$ \\
\hline $\mathrm{O} 2$ & C11 & N3 & $C 13$ & $-4.3(7)$ \\
\hline $\mathrm{O} 2$ & C11 & N3 & $\mathrm{Pd} 1$ & $172.8(4)$ \\
\hline C10 & C11 & $\mathrm{O} 2$ & C12 & $175.4(5)$ \\
\hline N3 & C11 & $\mathrm{O} 2$ & $\mathrm{C} 12$ & $-6.1(7)$ \\
\hline $\mathrm{H} 12 \mathrm{~A}$ & $\mathrm{C} 12$ & $\mathrm{C} 13$ & C14 & $-14.3(8)$ \\
\hline $\mathrm{H} 12 \mathrm{~A}$ & C12 & C13 & C15 & $-139.9(6)$ \\
\hline $\mathrm{H} 12 \mathrm{~A}$ & C12 & C13 & N3 & $104.7(6)$ \\
\hline $\mathrm{H} 12 \mathrm{~B}$ & C12 & C13 & C14 & $106.0(6)$ \\
\hline $\mathrm{H} 12 \mathrm{~B}$ & C12 & C13 & C15 & $-19.6(8)$ \\
\hline $\mathrm{H} 12 \mathrm{~B}$ & C12 & C13 & N3 & $-135.0(6)$ \\
\hline $\mathrm{O} 2$ & C12 & C13 & C14 & $-134.1(5)$ \\
\hline $\mathrm{O} 2$ & C12 & C13 & C15 & $100.2(6)$ \\
\hline $\mathrm{O} 2$ & C12 & C13 & N3 & $-15.1(6)$ \\
\hline
\end{tabular}




\begin{tabular}{|c|c|c|c|c|}
\hline $\mathrm{H} 12 \mathrm{~A}$ & C12 & $\mathrm{O} 2$ & C11 & $-106.3(6)$ \\
\hline $\mathrm{H} 12 \mathrm{~B}$ & $\mathrm{C} 12$ & $\mathrm{O} 2$ & C11 & $133.4(6)$ \\
\hline C13 & C12 & $\mathrm{O} 2$ & C11 & $13.5(6)$ \\
\hline C12 & C13 & C14 & $\mathrm{H} 14 \mathrm{~A}$ & $63.9(7)$ \\
\hline C12 & C13 & C14 & $\mathrm{H} 14 \mathrm{~B}$ & $-56.0(7)$ \\
\hline C12 & C13 & C14 & $\mathrm{H} 14 \mathrm{C}$ & $-176.0(5)$ \\
\hline C15 & $\mathrm{C} 13$ & C14 & $\mathrm{H} 14 \mathrm{~A}$ & $-171.4(5)$ \\
\hline C15 & $\mathrm{C} 13$ & C14 & $\mathrm{H} 14 \mathrm{~B}$ & $68.7(7)$ \\
\hline C15 & $\mathrm{C} 13$ & C14 & $\mathrm{H} 14 \mathrm{C}$ & $-51.3(7)$ \\
\hline N3 & C13 & C14 & $\mathrm{H} 14 \mathrm{~A}$ & $-48.0(7)$ \\
\hline N3 & C13 & C14 & $\mathrm{H} 14 \mathrm{~B}$ & $-168.0(5)$ \\
\hline N3 & C13 & C14 & $\mathrm{H} 14 \mathrm{C}$ & $72.1(7)$ \\
\hline $\mathrm{C} 12$ & $\mathrm{C} 13$ & C15 & $\mathrm{H} 15 \mathrm{~A}$ & $-173.2(5)$ \\
\hline $\mathrm{C} 12$ & $\mathrm{C} 13$ & C15 & H15B & $66.9(7)$ \\
\hline $\mathrm{C} 12$ & $\mathrm{C} 13$ & C15 & $\mathrm{H} 15 \mathrm{C}$ & $-53.3(7)$ \\
\hline C14 & C13 & C15 & $\mathrm{H} 15 \mathrm{~A}$ & $62.0(7)$ \\
\hline C14 & $\mathrm{C} 13$ & C15 & $\mathrm{H} 15 \mathrm{~B}$ & $-57.8(7)$ \\
\hline C14 & C13 & C15 & $\mathrm{H} 15 \mathrm{C}$ & $-178.0(6)$ \\
\hline N3 & C13 & C15 & $\mathrm{H} 15 \mathrm{~A}$ & $-63.0(7)$ \\
\hline N3 & C13 & C15 & $\mathrm{H} 15 \mathrm{~B}$ & $177.1(5)$ \\
\hline N3 & C13 & C15 & $\mathrm{H} 15 \mathrm{C}$ & $56.9(7)$ \\
\hline C12 & $\mathrm{C} 13$ & N3 & C11 & 12.0(6) \\
\hline C12 & $\mathrm{C} 13$ & N3 & $\mathrm{Pd} 1$ & $-164.8(4)$ \\
\hline C14 & $\mathrm{C} 13$ & N3 & C11 & $130.0(6)$ \\
\hline C14 & C13 & N3 & $\mathrm{Pd} 1$ & $-46.7(7)$ \\
\hline C15 & C13 & N3 & C11 & $-104.7(6)$ \\
\hline C15 & C13 & N3 & $\mathrm{Pd} 1$ & $78.5(6)$ \\
\hline C1 & N1 & Pd1 & N2 & 83.6(4) \\
\hline C1 & N1 & Pd1 & N3 & $99(1)$ \\
\hline C1 & N1 & $\mathrm{Pd} 1$ & $\mathrm{Cl} 1$ & $-93.1(4)$ \\
\hline C2 & N1 & $\mathrm{Pd} 1$ & N2 & $-153.2(5)$ \\
\hline C2 & N1 & $\mathrm{Pd} 1$ & N3 & $-138(1)$ \\
\hline C2 & N1 & $\mathrm{Pd} 1$ & $\mathrm{Cl} 1$ & $30.1(5)$ \\
\hline C3 & N1 & $\mathrm{Pd} 1$ & N2 & $-33.8(4)$ \\
\hline C3 & N1 & $\mathrm{Pd} 1$ & N3 & $-19(1)$ \\
\hline C3 & N1 & $\mathrm{Pd} 1$ & $\mathrm{Cl} 1$ & $149.5(4)$ \\
\hline C4 & $\mathrm{N} 2$ & Pd1 & N1 & $26.2(5)$ \\
\hline C4 & $\mathrm{N} 2$ & $\mathrm{Pd} 1$ & N3 & $-151.5(5)$ \\
\hline C4 & $\mathrm{N} 2$ & $\mathrm{Pd} 1$ & $\mathrm{Cl} 1$ & $52(2)$ \\
\hline C5 & $\mathrm{N} 2$ & Pd1 & N1 & $-149.3(5)$ \\
\hline C5 & $\mathrm{N} 2$ & $\mathrm{Pd} 1$ & N3 & $33.0(5)$ \\
\hline C5 & $\mathrm{N} 2$ & $\mathrm{Pd} 1$ & $\mathrm{Cl} 1$ & $-123(1)$ \\
\hline C11 & N3 & $\mathrm{Pd} 1$ & N1 & $-30(2)$ \\
\hline
\end{tabular}




\begin{tabular}{|c|c|c|c|c|}
\hline C11 & N3 & Pd1 & N2 & $-14.7(5)$ \\
\hline C11 & N3 & Pd1 & $\mathrm{Cl} 1$ & $162.3(5)$ \\
\hline C13 & N3 & Pd1 & N1 & $147(1)$ \\
\hline C13 & N3 & Pd1 & N2 & $161.8(5)$ \\
\hline C13 & N3 & $\mathrm{Pd} 1$ & $\mathrm{Cl} 1$ & $-21.2(5)$ \\
\hline $\mathrm{H} 16 \mathrm{~A}$ & C16 & N4 & C17 & $53.0(7)$ \\
\hline H16A & C16 & N4 & C18 & $172.2(5)$ \\
\hline $\mathrm{H} 16 \mathrm{~A}$ & C16 & N4 & $\mathrm{Pd} 2$ & $-71.0(7)$ \\
\hline H16B & C16 & N4 & C17 & $-66.9(7)$ \\
\hline H16B & C16 & N4 & C18 & $52.3(7)$ \\
\hline H16B & C16 & N4 & $\mathrm{Pd} 2$ & $169.1(4)$ \\
\hline $\mathrm{H} 16 \mathrm{C}$ & C16 & N4 & C17 & $173.2(5)$ \\
\hline $\mathrm{H} 16 \mathrm{C}$ & C16 & N4 & C18 & $-67.6(7)$ \\
\hline $\mathrm{H} 16 \mathrm{C}$ & C16 & N4 & $\mathrm{Pd} 2$ & $49.2(7)$ \\
\hline H17A & C17 & N4 & C16 & $174.8(5)$ \\
\hline H17A & C17 & N4 & C18 & $57.0(7)$ \\
\hline H17A & C17 & N4 & $\mathrm{Pd} 2$ & $-55.3(6)$ \\
\hline H17B & C17 & N4 & C16 & $54.9(7)$ \\
\hline H17B & C17 & N4 & C18 & $-62.9(7)$ \\
\hline H17B & C17 & N4 & $\mathrm{Pd} 2$ & $-175.2(4)$ \\
\hline $\mathrm{H} 17 \mathrm{C}$ & C17 & N4 & C16 & $-65.1(7)$ \\
\hline $\mathrm{H} 17 \mathrm{C}$ & C17 & N4 & C18 & $177.1(5)$ \\
\hline $\mathrm{H} 17 \mathrm{C}$ & C17 & N4 & $\mathrm{Pd} 2$ & $64.8(6)$ \\
\hline H18A & C18 & C19 & N5 & $103.4(6)$ \\
\hline H18A & C18 & C19 & $\mathrm{O} 3$ & $-73.9(8)$ \\
\hline H18B & C18 & C19 & N5 & $-139.0(6)$ \\
\hline H18B & C18 & C19 & $\mathrm{O} 3$ & $43.7(8)$ \\
\hline N4 & C18 & C19 & N5 & $-17.8(7)$ \\
\hline N4 & C18 & C19 & $\mathrm{O} 3$ & $164.9(6)$ \\
\hline H18A & C18 & N4 & C16 & $42.9(7)$ \\
\hline H18A & C18 & N4 & C17 & $161.3(5)$ \\
\hline H18A & C18 & N4 & $\mathrm{Pd} 2$ & $-83.4(5)$ \\
\hline H18B & C18 & N4 & C16 & $-74.7(6)$ \\
\hline H18B & C18 & N4 & C17 & $43.8(7)$ \\
\hline H18B & C18 & N4 & $\mathrm{Pd} 2$ & $159.0(5)$ \\
\hline C19 & C18 & N4 & C16 & $164.1(5)$ \\
\hline C19 & C18 & N4 & C17 & $-77.5(6)$ \\
\hline C19 & C18 & N4 & $\mathrm{Pd} 2$ & $37.8(6)$ \\
\hline C18 & C19 & N5 & C20 & $168.4(5)$ \\
\hline C18 & C19 & N5 & $\mathrm{Pd} 2$ & $-13.4(6)$ \\
\hline O3 & C19 & N5 & C20 & $-15(1)$ \\
\hline O3 & C19 & N5 & $\mathrm{Pd} 2$ & 163.6(6) \\
\hline C25 & C20 & C21 & $\mathrm{H} 21$ & $178.4(6)$ \\
\hline
\end{tabular}




$\begin{array}{lllll}\mathrm{C} 25 & \mathrm{C} 20 & \mathrm{C} 21 & \mathrm{C} 22 & -2(1) \\ \mathrm{N} 5 & \mathrm{C} 20 & \mathrm{C} 21 & \mathrm{H} 21 & -1(1) \\ \mathrm{N} 5 & \mathrm{C} 20 & \mathrm{C} 21 & \mathrm{C} 22 & 178.8(6) \\ \mathrm{C} 21 & \mathrm{C} 20 & \mathrm{C} 25 & \mathrm{C} 24 & 1.4(9) \\ \mathrm{C} 21 & \mathrm{C} 20 & \mathrm{C} 25 & \mathrm{C} 26 & 178.3(6) \\ \mathrm{N} 5 & \mathrm{C} 20 & \mathrm{C} 25 & \mathrm{C} 24 & -178.9(6) \\ \mathrm{N} 5 & \mathrm{C} 20 & \mathrm{C} 25 & \mathrm{C} 26 & -2.0(9) \\ \mathrm{C} 21 & \mathrm{C} 20 & \mathrm{~N} 5 & \mathrm{C} 19 & -25.7(9) \\ \mathrm{C} 21 & \mathrm{C} 20 & \mathrm{~N} 5 & \mathrm{P} 2 & 156.4(5) \\ \mathrm{C} 25 & \mathrm{C} 20 & \mathrm{~N} 5 & \mathrm{C} 19 & 154.6(6) \\ \mathrm{C} 25 & \mathrm{C} 20 & \mathrm{~N} 5 & \mathrm{P} 2 & -23.3(8) \\ \mathrm{C} 20 & \mathrm{C} 21 & \mathrm{C} 22 & \mathrm{H} 22 & 179.9(7) \\ \mathrm{C} 20 & \mathrm{C} 21 & \mathrm{C} 22 & \mathrm{C} 23 & -0(1) \\ \mathrm{H} 21 & \mathrm{C} 21 & \mathrm{C} 22 & \mathrm{H} 22 & -0(1) \\ \mathrm{H} 21 & \mathrm{C} 21 & \mathrm{C} 22 & \mathrm{C} 23 & 180.0(7) \\ \mathrm{C} 21 & \mathrm{C} 22 & \mathrm{C} 23 & \mathrm{H} 23 & -178.2(7) \\ \mathrm{C} 21 & \mathrm{C} 22 & \mathrm{C} 23 & \mathrm{C} 24 & 2(1) \\ \mathrm{H} 22 & \mathrm{C} 22 & \mathrm{C} 23 & \mathrm{H} 23 & 2(1) \\ \mathrm{H} 22 & \mathrm{C} 22 & \mathrm{C} 23 & \mathrm{C} 24 & -178.2(7) \\ \mathrm{C} 22 & \mathrm{C} 23 & \mathrm{C} 24 & \mathrm{H} 24 & 178.1(7) \\ \mathrm{C} 22 & \mathrm{C} 23 & \mathrm{C} 24 & \mathrm{C} 25 & -2(1) \\ \mathrm{H} 23 & \mathrm{C} 23 & \mathrm{C} 24 & \mathrm{H} 24 & -2(1) \\ \mathrm{H} 23 & \mathrm{C} 23 & \mathrm{C} 24 & \mathrm{C} 25 & 178.1(6) \\ \mathrm{C} 23 & \mathrm{C} 24 & \mathrm{C} 25 & \mathrm{C} 20 & 0(1) \\ \mathrm{C} 23 & \mathrm{C} 24 & \mathrm{C} 25 & \mathrm{C} 26 & -176.9(6) \\ \mathrm{H} 24 & \mathrm{C} 24 & \mathrm{C} 25 & \mathrm{C} 20 & -179.7(6) \\ \mathrm{H} 24 & \mathrm{C} 24 & \mathrm{C} 25 & \mathrm{C} 26 & 3.2(9) \\ \mathrm{C} 20 & \mathrm{C} 25 & \mathrm{C} 26 & \mathrm{~N} 6 & 17(1) \\ \mathrm{C} 20 & \mathrm{C} 25 & \mathrm{C} 26 & \mathrm{O} 4 & -163.4(6) \\ \mathrm{C} 24 & \mathrm{C} 25 & \mathrm{C} 26 & \mathrm{~N} 6 & -166.2(6) \\ \mathrm{C} 24 & \mathrm{C} 25 & \mathrm{C} 26 & \mathrm{O} 4 & 13.6(8) \\ \mathrm{C} 25 & \mathrm{C} 26 & \mathrm{~N} 6 & \mathrm{C} 28 & -179.6(6) \\ \mathrm{C} 25 & \mathrm{C} 26 & \mathrm{~N} 6 & \mathrm{Pd} 2 & -3.6(9) \\ \mathrm{O} 4 & \mathrm{C} 26 & \mathrm{~N} 6 & \mathrm{C} 28 & 0.7(7) \\ \mathrm{O} 4 & \mathrm{C} 26 & \mathrm{~N} 6 & \mathrm{P} 22 & 176.7(4) \\ \mathrm{C} 25 & \mathrm{C} 26 & \mathrm{O} 4 & \mathrm{C} 27 & 168.4(5) \\ \mathrm{N} 6 & \mathrm{C} 26 & \mathrm{O} 4 & \mathrm{C} 27 & -11.8(7) \\ \mathrm{H} 27 \mathrm{~A} & \mathrm{C} 27 & \mathrm{C} 28 & \mathrm{C} 29 & -14.4(8) \\ \mathrm{H} 27 \mathrm{~A} & \mathrm{C} 27 & \mathrm{C} 28 & \mathrm{C} 30 & -141.0(6) \\ \mathrm{H} 27 \mathrm{~A} & \mathrm{C} 27 & \mathrm{C} 28 & \mathrm{~N} 6 & 103.7(6) \\ \mathrm{H} 27 \mathrm{~B} & \mathrm{C} 27 & \mathrm{C} 28 & \mathrm{C} 29 & 106.3(6) \\ \mathrm{H} 27 \mathrm{~B} & \mathrm{C} 27 & \mathrm{C} 28 & \mathrm{C} 30 & -20.3(8) \\ \mathrm{H} 27 \mathrm{~B} & \mathrm{C} 27 & \mathrm{C} 28 & \mathrm{~N} 6 & -135.6(5)\end{array}$




$\begin{array}{lllll}\mathrm{O} 4 & \mathrm{C} 27 & \mathrm{C} 28 & \mathrm{C} 29 & -134.1(5) \\ \mathrm{O} 4 & \mathrm{C} 27 & \mathrm{C} 28 & \mathrm{C} 30 & 99.3(6) \\ \mathrm{O} 4 & \mathrm{C} 27 & \mathrm{C} 28 & \mathrm{~N} 6 & -16.0(6) \\ \mathrm{H} 27 \mathrm{~A} & \mathrm{C} 27 & \mathrm{O} 4 & \mathrm{C} 26 & -102.5(6) \\ \mathrm{H} 27 \mathrm{~B} & \mathrm{C} 27 & \mathrm{O} 4 & \mathrm{C} 26 & 136.9(6) \\ \mathrm{C} 28 & \mathrm{C} 27 & \mathrm{O} 4 & \mathrm{C} 26 & 17.2(6) \\ \mathrm{C} 27 & \mathrm{C} 28 & \mathrm{C} 29 & \mathrm{H} 29 \mathrm{~A} & 54.3(7) \\ \mathrm{C} 27 & \mathrm{C} 28 & \mathrm{C} 29 & \mathrm{H} 29 \mathrm{~B} & -65.6(7) \\ \mathrm{C} 27 & \mathrm{C} 28 & \mathrm{C} 29 & \mathrm{H} 29 \mathrm{C} & 174.3(5) \\ \mathrm{C} 30 & \mathrm{C} 28 & \mathrm{C} 29 & \mathrm{H} 29 \mathrm{~A} & 178.6(6) \\ \mathrm{C} 30 & \mathrm{C} 28 & \mathrm{C} 29 & \mathrm{H} 29 \mathrm{~B} & 58.7(7) \\ \mathrm{C} 30 & \mathrm{C} 28 & \mathrm{C} 29 & \mathrm{H} 29 \mathrm{C} & -61.3(7) \\ \mathrm{N} 6 & \mathrm{C} 28 & \mathrm{C} 29 & \mathrm{H} 29 \mathrm{~A} & -56.8(7) \\ \mathrm{N} 6 & \mathrm{C} 28 & \mathrm{C} 29 & \mathrm{H} 29 \mathrm{~B} & -176.7(5) \\ \mathrm{N} 6 & \mathrm{C} 28 & \mathrm{C} 29 & \mathrm{H} 29 \mathrm{C} & 63.2(7) \\ \mathrm{C} 27 & \mathrm{C} 28 & \mathrm{C} 30 & \mathrm{H} 30 \mathrm{~A} & -177.0(6) \\ \mathrm{C} 27 & \mathrm{C} 28 & \mathrm{C} 30 & \mathrm{H} 30 \mathrm{~B} & 63.1(7) \\ \mathrm{C} 27 & \mathrm{C} 28 & \mathrm{C} 30 & \mathrm{H} 30 \mathrm{C} & -56.9(7) \\ \mathrm{C} 29 & \mathrm{C} 28 & \mathrm{C} 30 & \mathrm{H} 30 \mathrm{~A} & 58.5(8) \\ \mathrm{C} 29 & \mathrm{C} 28 & \mathrm{C} 30 & \mathrm{H} 30 \mathrm{~B} & -61.5(8) \\ \mathrm{C} 29 & \mathrm{C} 28 & \mathrm{C} 30 & \mathrm{H} 30 \mathrm{C} & 178.5(6) \\ \mathrm{N} 6 & \mathrm{C} 28 & \mathrm{C} 30 & \mathrm{H} 30 \mathrm{~A} & -67.3(7) \\ \mathrm{N} 6 & \mathrm{C} 28 & \mathrm{C} 30 & \mathrm{H} 30 \mathrm{~B} & 172.7(5) \\ \mathrm{N} 6 & \mathrm{C} 28 & \mathrm{C} 30 & \mathrm{H} 30 \mathrm{C} & 52.8(7) \\ \mathrm{C} 27 & \mathrm{C} 28 & \mathrm{~N} 6 & \mathrm{C} 26 & 9.8(6) \\ \mathrm{C} 27 & \mathrm{C} 28 & \mathrm{~N} 6 & \mathrm{Pd} 2 & -165.9(4) \\ \mathrm{C} 29 & \mathrm{C} 28 & \mathrm{~N} 6 & \mathrm{C} 26 & 126.9(5) \\ \mathrm{C} 29 & \mathrm{C} 28 & \mathrm{~N} 6 & \mathrm{Pd} 2 & -48.8(7) \\ \mathrm{C} 30 & \mathrm{C} 28 & \mathrm{~N} 6 & \mathrm{C} 26 & -106.0(6) \\ \mathrm{C} 30 & \mathrm{C} 28 & \mathrm{~N} 6 & \mathrm{Pd} 2 & 78.3(6) \\ \mathrm{C} 16 & \mathrm{~N} 4 & \mathrm{Pd} 2 & \mathrm{~N} 5 & -154.1(5) \\ \mathrm{C} 16 & \mathrm{~N} 4 & \mathrm{Pd} 2 & \mathrm{~N} 6 & -147(1) \\ \mathrm{C} 16 & \mathrm{~N} 4 & \mathrm{Pd} 2 & \mathrm{Cl} 2 & 28.1(4) \\ \mathrm{C} 17 & \mathrm{~N} 4 & \mathrm{P} 2 & \mathrm{~N} 5 & 81.6(4) \\ \mathrm{C} 17 & \mathrm{~N} 4 & \mathrm{Pd} 2 & \mathrm{~N} 6 & 89(1) \\ \mathrm{C} 17 & \mathrm{~N} 4 & \mathrm{Pd} 2 & \mathrm{Cl} 2 & -96.2(4) \\ \mathrm{C} 18 & \mathrm{~N} 4 & \mathrm{Pd} 2 & \mathrm{~N} 5 & -35.0(4) \\ \mathrm{C} 18 & \mathrm{~N} 4 & \mathrm{Pd} 2 & \mathrm{~N} 6 & -28(2) \\ \mathrm{C} 18 & \mathrm{~N} 4 & \mathrm{Pd} 2 & \mathrm{Cl} 2 & 147.1(3) \\ \mathrm{C} 19 & \mathrm{~N} 5 & \mathrm{Pd} 2 & \mathrm{~N} 4 & 28.6(4) \\ \mathrm{C} 19 & \mathrm{~N} 5 & \mathrm{Pd} 2 & \mathrm{~N} 6 & -150.4(4) \\ \mathrm{C} 19 & \mathrm{~N} 5 & \mathrm{Pd} 2 & \mathrm{Cl} 2 & 45(1) \\ \mathrm{C} 20 & \mathrm{~N} 5 & \mathrm{Pd} 2 & \mathrm{~N} 4 & -153.3(5) \\ & & & & \\ & & & \end{array}$




\begin{tabular}{lllll}
$\mathrm{C} 20$ & $\mathrm{~N} 5$ & $\mathrm{Pd} 2$ & $\mathrm{~N} 6$ & $27.6(5)$ \\
$\mathrm{C} 20$ & $\mathrm{~N} 5$ & $\mathrm{Pd} 2$ & $\mathrm{Cl}$ & $-137(1)$ \\
$\mathrm{C} 26$ & $\mathrm{~N} 6$ & $\mathrm{Pd} 2$ & $\mathrm{~N} 4$ & $-21(2)$ \\
$\mathrm{C} 26$ & $\mathrm{~N} 6$ & $\mathrm{Pd} 2$ & $\mathrm{~N} 5$ & $-14.2(5)$ \\
$\mathrm{C} 26$ & $\mathrm{~N} 6$ & $\mathrm{Pd} 2$ & $\mathrm{Cl} 2$ & $163.8(4)$ \\
$\mathrm{C} 28$ & $\mathrm{~N} 6$ & $\mathrm{Pd} 2$ & $\mathrm{~N} 4$ & $154(1)$ \\
$\mathrm{C} 28$ & $\mathrm{~N} 6$ & $\mathrm{Pd} 2$ & $\mathrm{~N} 5$ & $160.9(5)$ \\
$\mathrm{C} 28$ & $\mathrm{~N} 6$ & $\mathrm{Pd} 2$ & $\mathrm{Cl}$ & $-21.1(5)$ \\
\hline
\end{tabular}




\section{CHAPTER 8 - REFERENCES}

(1) Bhattacharya, P.; Guan, H. Synthesis and catalytic applications of iron pincer complexes. Comments Inorg. Chem. 2011, 32, 88-112.

(2) Constable, E. C.; Housecroft, C. E. Coordination chemistry: the scientific legacy of Alfred Werner. Chem. Soc. Rev. 2013, 42, 1429-1439.

(3) Miessler, G. L.; Tarr, D. A. Inorganic Chemistry, $3^{\text {rd }}$ ed.; Prentice Hall: New Jersey, 2003.

(4) Gwynne, E. A.; Stephan, D. W. Nickel(II) and Palladium(II) bis-aminophosphine pincer complexes. Organometallics 2011, 30, 4128-4135.

(5) Zargarian, D.; Castronguay, A.; Spasyuk, D. M. ECE-type pincer complexes of nickel. Top. Organomet. Chem. 2013, 40, 131-173.

(6) Morales-Morales, D. Pincer complexes. Applications in catalysis. Rev. Soc. Quim. Mex. 2004, 48, 338-346.

(7) Motoyama, Y.; Shimozono, K.; Nishiyama, H. Novel (oxazolinyl)phenyl phosphine pincer ligand: development of the first non-symmetrical, PCN type chiral palladium and platinum complexes. Inorg. Chim. Acta, 2006, 359, 1725-1730.

(8) Vicente, J.; Arcas, A.; Julia-Hernandez, F. Organometallic complexes of palladium(II) derived from 2,6-diacetylpyridine dimethylketal. Organometallics 2010, 29, 3066-3076.

(9) Ito, J.; Ujiie, S.; Nishiyama, H. Chiral bis(oxazolinyl)phenyl Rull catalysts for highly enantioselective cyclopropanation. Chem. Eur. J. 2010, 16, 4986-4990.

(10) Konrad, F.; Fillol, J. L.; Rettenmeier, C.; Wadepohl, H.; Gade, L. H. Bis(oxazolinylmethyl) derivatives of $\mathrm{C}_{4} \mathrm{H}_{4} \mathrm{E}$ heterocycles $(\mathrm{E}=\mathrm{NH}, \mathrm{O}, \mathrm{S})$ as $\mathrm{C}_{2^{-}}$ 
chiral meridionally coordinating ligands for nickel and chromium. Eur. J. Inorg. Chem. 2009, 4950-4961.

(11) El-Zaria, M. E.; Arii, H.; Nakamura, H. m-Carborane based chiral NBN pincermetal complexes: synthesis, structure, and application in asymmetric catalysis. Inorg. Chem. 2011, 50, 4149-4161.

(12) Polukeev, A. V.; Kuklin, S. A.; Petrovskii, P. V.; Peregudova, S. M.; Smol'yakov, A. F.; Dolgushin, F. M.; Koridze, A. A. Synthesis and characterization of fluorophenylpalladium pincer complexes: electronic properties of some pincer ligands evaluated by multinuclear NMR spectroscopy and electrochemical studies. Dalton Trans. 2011, 40, 7201-7209.

(13) Gossage, R. A. Pincer oxazolines: emerging tools in coordination chemistry and catalysis - where to next? Dalton Trans. 2011, 40, 8755-8759.

(14) Hollas, A. M; Gu, W.; Bhuvanesh, N.; Ozerov, O. V. Synthesis and characterization of $\mathrm{Pd}$ complexes of a carbazolyl/bis(imine) NNN pincer ligand. Inorg. Chem. 2011, 50, 3673-3679.

(15) Kumar, S.; Mani, G.; Mondal, S.; Chattaraj, P. K. Pyrrole-based new diphosphines: Pd and Ni complexes bearing the PNP pincer ligand. Inorg. Chem. 2012, 51, 12527-12539.

(16) Vabre, B.; Canac. Y.; Duhayon, C.; Chauvin, R.; Zargarian, D. Nickel(II) complexes of the new pincer-type unsymmetrical ligands PIMCOP, PIMIOCOP, and NHCCOP: versatile binding motifs. Chem. Commun. 2012, 48, 1044610448. 
(17) Herbert, D. E.; Miller, A. D.; Ozerov, O. V. Phosphorus(III) cations supported by a PNP pincer ligand and sub-stoichiometric generation of $\mathrm{P}_{4}$ from thermolysis of a nickel insertion product. Chem. Eur. J. 2012, 18, 7696-7704.

(18) Castonguay, A.; Sui-Seng, C.; Zargarian, D.; Beauchamp, A. L. Synthesis and reactivities of new $\mathrm{PC}_{\mathrm{sp} 3} \mathrm{P}$ pincer complexes of nickel. Organometallics 2006, 25, $602-608$.

(19) Ruddy, A. J.; Mitton, S. J.; McDonald, R.; Turculet, L. 'Hemilabile' silyl pincer ligation: platinum group PSiN complexes and triple $\mathrm{C}-\mathrm{H}$ activation to form a (PSiC) Ru carbene complex. Chem. Commun. 2012, 48, 1159-1161.

(20) Lindner, R.; van den Bosch, B.; Lutz, M.; Reek, J. N. H.; van der Vlugt, J. I. Tunable hemilabile ligands for adoptive transition metal complexes. Organometallics 2011, 30, 499-510.

(21) van Koten, G. The monoanionic ECE-pincer ligand: a versatile privileged ligand platform - general considerations. Top. Organomet. Chem. 2013, 40, 1-20.

(22) Zhang, J.; Pattacini, R.; Braunstein, P. Tridentate assembling ligands based on oxazoline and phosphorus donors in dinuclear $\mathrm{Pd}(\mathrm{I})-\mathrm{Pd}(\mathrm{I})$ complexes. Inorg. Chem. 2009, 48, 11954-11962.

(23) Gossage, R. A.; Jenkins, H. A.; Yadav, P. N. Application of an air stable Pd oxazoline complex for Heck, Suzuki, Sonogashira and related C-C bond-forming reactions. Tetrahedron Lett. 2004, 45, 7689-7691 (Corrigendum: 2005, 46, 5243).

(24) Button, K. M.; Gossage, R. A.; Phillips, R. K. R. A simple large scale synthesis of 1,3-bis(4,4-dimethyl-2-oxazolinyl)benzene. Synth. Commun. 2002, 32, 363-368. 
(25) Fossey, J. S.; Richards, C. J. Synthesis of 2,6-bis(2-oxazolinyl)phenylplatinum(II) NCN pincer complexes by direct cyclometalation. Catalysts for carbon-carbon bond formation. Organometallics 2004, 23, 367-373.

(26) Younus, H. A.; Ahmad, N.; Su, W.; Verpoort, F. Ruthenium pincer complexes: Ligand design and complex synthesis. Coord. Chem. Rev. 2014, 276, 112-152.

(27) Ito, J.; Nishiyama, H. Synthetic utility of chiral bis(oxazolinyl)phenyl transitionmetal complexes. Synlett, 2012, 509-523.

(28) Nishiyama, H. Synthesis and use of bisoxazolinyl-phenyl pincers. Chem. Soc. Rev. 2007, 36, 1133-1141.

(29) Ito, J.; Nishiyama, H. Recent topics of transfer hydrogenation. Tetrahedron Lett. 2014, 55, 3153-3166.

(30) Toda, T.; Kuwata, S.; Ikariya, T. Unsymmetrical pincer-type ruthenium complex containing $\beta$-protic pyrazole and $N$-heterocyclic carbene arms: comparison of brønsred acidity of $\mathrm{NH}$ groups in second coordination sphere. Chem. Eur. J. 2014, 20, 9539-9542.

(31) Ebeling, G.; Meneghetti, M. R.; Rominger, F.; Dupont, J. The transchlorometalation of hetero-substituted alkynes: A facile entry to unsymmetrical palladium $\mathrm{YCY}$ ' $\left(\mathrm{Y}, \mathrm{Y}^{\prime}=\mathrm{NR}_{2}, \mathrm{PPh}_{2}, \mathrm{OPPh}_{2}\right.$, and $\left.\mathrm{SR}\right)$ "pincer" complexes Organometallics 2002, 21, 3221-3227.

(32) Dietrich, B. L.; Egbert, J.; Morris, A. M.; Wicholas, M. Cd(II), Zn(II), and Pd(II) complexes of an isoindoline pincer ligand: consequences of steric crowding. Inorg. Chem. 2005, 44, 6476-6481. 
(33) Schaub, T.; Radius, U.; Diskin-Posner, Y.; Leitus, G.; Shimon, L. J. W.; Milstein, D. Pyridine-based sulfoxide pincer complexes of Rhodium and Iridium. Organometallics 2008, 27, 1892-1901.

(34) Liu, A.; Zhang, X.; Chen, W. New pincer CC'C complexes of Nickel(II) via chloronickelation of alkyne-bearing $N$-heterocyclic carbenes. Organometallics 2009, 28, 4868-4871.

(35) Lien, Y.-L.; Chang, Y.-C.; Chuang, N.-T.; Datta, A.; Chen, S.-J.; Hu, C.-H.; Huang, W.-Y.; Lin, C.-H.; Huang, J.-H. A new type of asymmetric tridentate pyrrolyl-linked pincer ligand and its aluminum dihydride complexes. Inorg. Chem. 2010, 49, 136143.

(36) Shibue, M.; Hirotsu, M.; Nishioka, T.; Kinoshita, I. Ruthenium and Rhodium complexes with thiolate-containing pincer ligands produced by $\mathrm{C}-\mathrm{S}$ bond cleavage of pyridyl-substituted dibenzothiophenes. Organometallics 2008, 27, 4475-4483.

(37) Juliá-Hernández, F.; Arcas, A.; Vicente, J. Chem. Eur. J. 2012, 18, 7780.

(38) Pozo del, C.; Corma, A.; Iglesias, M.; Sánchez, F. Recyclable mesoporous silicasupported chiral ruthenium-(NHC)NN-pincer catalysts for asymmetric reactions. Green Chem. 2011, 13, 2471-2481.

(39) Baratta, W.; Benedetti, F.; Zotto, A. D.; Fanfoni, L.; Felluga, F.; Magnolia, S.; Putignano, E.; Rigo, P. Chiral pincer ruthenium and osmium complexes for the fast and efficient hydrogen transfer reduction of ketones. Organometallics 2010, $29,3563-3570$. 
(40) Du, W.; Wang, L.; Wu, P.; Yu, Z. A versatile ruthenium(II)-NNC complex catalyst for transfer hydrogenation of ketones and oppenauer-type oxidation of alcohols. Chem. Eur. J. 2012, 18, 11550-11554.

(41) Boronat, M.; Corma, A.; Gornález-Arellano, C.; Iglesias, M.; Sánchez, F. Synthesis of electron-rich CNN-pincer complexes, with $\mathrm{N}$-heterocyclic carbene and (S)-proline moieties and application to asymmetric hydrogenation. Organometallics 2010, 29, 134-141.

(42) Bröring, M.; Kleeberg, C.; Köhler, S. Palladium(II) complexes of unsymmetrical CNN pincer ligands. Inorg. Chem. 2008, 47, 6404-6412.

(43) Zeng, G.; \& Li, S. Insights into dehydrogenative coupling of alcohols and amines catalyzed by a (PNN)-Ru(II) hydride complex: unusual metal-ligand cooperation. Inorg. Chem. 2011, 50, 10572-10580.

(44) Zhang, J.; Balaraman, E.; Leitus, G.; Milstein, D. Electron-rich PNP- and PNNtype ruthenium(II) hydrido borohydride pincer complexes. Synthesis, structure, and catalytic dehydrogenation of alcohols and hydrogenation of esters. Organometallics 2011, 30, 5716-5724.

(45) He, L.-P.; Chen, T.; Gong, D.; Lai, Z.; Huang, K.-W. Enhanced reactivities toward amines by introducing an imine arm to the pincer ligand: direct coupling of two amines to form an imine without oxidant. Organometallics 2012, 31, 5208-5211.

(46) Decken, A.; Gossage, R. A.; Yadav, P. N. Oxazoline Chemistry-Part VIII: Synthesis and characterisation of a new class of pincer ligands derived from the 2-(o-anilinyl)-2-oxazoline skeleton: applications to the synthesis of group $X$ transition metal catalysts. Can. J. Chem. 2005, 83, 1185-1189. 
(47) Taghvaee, M. Group XI Pincer Oxazoline Complexes. MSc Thesis, 2012, Ryerson University.

(48) Durran, S. E.; Elsegood, M. R. J.; Hammond, S. R.; Smith, M. B. Flexible $k^{4}-$ PNN'O-tetradentate ligands: synthesis, complexation and structural studies. Dalton Trans. 2010, 39, 7136-7146.

(49) Button, K. M.; Gossage, R. A. Oxazoline chemistry part III. Synthesis and characterization of [2-(2'-anilinyl)-2-oxazolines] and some related compounds. J. Heterocyclic Chem. 2003, 40, 513-517.

(50) Hornback, J. M. Organic Chemistry, $2^{\text {nd }}$ Ed. Brooks/Cole: Belmont, 2006.

(51) Kunishima, M.; Kawachi, C.; Morita, J.; Terao, K.; Iwasaki, F.; Tani, S. 4-(4,6Dimethyl-1,3,5-triazin-2-yl)-4-methyl-morpholinium chloride: an efficient condensing agent leading to the formation of amides and esters. Tetrahedron 1999, 55, 13159-13170.

(52) Jarrold, M. F. Peptides and proteins in the vapor phase. Annu. Rev. Phys. Chem. 2000, 51, 179-207.

(53) Lesarri, A.; Cocinero, E. J.; Lopez, J. C.; Alonso, J. L. Gas-phase structure of N,N-dimethylglycine. Chem. Phys. Chem. 2005, 6, 1559-1566.

(54) Herasymchuk, K. Novel pincer ligands derived from 2-(2'-anilinyl)-4,4-dimethyl-2oxazoline skeleton. BSc Thesis. 2012, Ryerson University.

(55) Yella, R. Chloroacetylchloride: A Versatile Reagent in Heterocyclic Synthesis. Synlett. 2010, 835-836.

(56) Raycroft, M. A. R.; Maxwell, C. I.; Oldham, R. A. A.; Andrea, A. S.; Neverov, A. A.; Brown, R. S. Trifunctional metal ion-catalyzed solvolysis: Cu(II)-promoted 
methanolysis of $\mathrm{N}, \mathrm{N}$-bis(2-picolyl) benzamides involves unusual lewis acid activation of substrate, delivery of coordinated nucleophile, powerful assistance of the leaving group departure. Inorg. Chem. 2012, 51, 10325-10333.

(57) Xu, S.; Held, I.; Kempf, B.; Mayr, H.; Steglich, W.; Zipse, H. The DMAPCatalyzed Acetylation of Alcohols-A Mechanistic Study (DMAP=4(Dimethylamino)pyridine). Chem. Eur. J. 2005, 11, 4751-4757.

(58) Ghorbani-Choghamarani, A.; Norouzi, M. Protection of hydroxyl groups as a trimethylsilyl ether by 1,1,1,3,3,3-hexamethyldisilazane promoted by aspartic acid as an efficient organocatalyst. Chin. J. Chem. 2011, 32, 595-598.

(59) Wuts, P. G. M.; Greene, T. W. Greene's Protective Groups in Organic Synthesis, $4^{\text {th }}$ Ed. John Wiley \& Sons, United States: New Jersey, 2007.

(60) Huynh, J. Optimization of the novel pincer ligand derived from 2-(2'-anilinyl)-2oxazolines. BSc Thesis. 2014, Ryerson University.

(61) Reich, H. J. Chemical Shift. www.chem.wisc.edu/areas/reich/nmr/notes-5-hmr-2shift.pdf, (accessed August 2, 2014).

(62) Bara, J. E. Versatile and Scalable Method for Producing N-Functionalized Imidazoles. Ind. Eng. Chem. Res. 2011, 50, 13614-13619.

(63) Stankevič, M.; Włodarczyk, A.; Jaklińska, M.; Parcheta, R.; Pietrusiewicz, K. M. Sodium in liquid ammonia - a versatile tool in modifications of arylphosphine oxides. Tetrahedron 2011, 67, 8671-8678.

(64) Rohlik, Z.; Holzhauser, P.; Kotek, J.; Rudovsky, J.; Nemec, I.; Hermann, P.; Lukes, I. Synthesis and coordination properties of palladium(II) and platinum(II) 
complexes with phosphonated triphenylphosphine derivatives. J. Organomet. Chem. 2006, 691, 2409-2423.

(65) Dornhaus, F.; Bolte, M.; Lerner, H.-W.; Wagner, M. Phosphanylborohydrides: first assessment of the relative lewis basicities of $\left[\mathrm{BH}_{3} \mathrm{PPh}_{2}\right]^{-}, \mathrm{CH}_{3} \mathrm{PPh}_{2}$, and $\mathrm{HPPh}_{2}$. Eur. J. Inorg. Chem. 2006, 1777-1785.

(66) Pavia, D. L.; Lampman, G. M.; Kriz, G. S.; Vyvyan, J. R. Introduction to spectroscopy, $4^{\text {th }}$ Ed. Saunders Brooks/Cole Thompson Learning, United States: Belmont, 2009.

(67) Schmid, T. E.; Jones, D. C.; Songis, O.; Diebolt, O.; Furst, M. R. L.; Slawin, A. M. Z.; Cazin, C. S. J. Mixed phosphine/ $N$-heterocyclic carbene palladium complexes: synthesis, characterization and catalytic use in aqueous SuzukiMiyaura reactions. Dalton Trans., 2013, 42, 7345-7353.

(68) Tessin, U. I.; Bantreil, X.; Songis, O.; Cazin, C. S. J. Highly active $[\operatorname{Pd}(\mu-$ $\mathrm{Cl}) \mathrm{Cl}(\mathrm{NHC})]_{2}$ complexes in the Mizoroki-Heck reaction. Eur. J. Inorg. Chem. 2013, 2007-2010.

(69) Boronat, M.; Corma, A.; Gornález-Arellano, C.; Iglesias, M.; Sánchez, F. Synthesis of electron-rich CNN-pincer complexes, with $\mathrm{N}$-heterocyclic carbene and (S)-proline moieties and application to asymmetric hydrogenation. Organometallics 2010, 29, 134-141.

(70) Tu, T.; Malineni, J.; Dötz, K. H. A novel pyridine-bridged bis-benzimidazolylidene pincer palladium complex: synthesis and catalytic properties. Adv. Synth. Catal. 2008, 350, 1791-1795. 
(71) Santoro, O.; Collado, A.; Slawin, A. M. Z.; Nolan, S. P.; Cazin, C. S. J. A general synthetic route to $[\mathrm{Cu}(\mathrm{X})(\mathrm{NHC})](\mathrm{NHC}=\mathrm{N}$-heterocyclic carbene, $\mathrm{X}=\mathrm{Cl}, \mathrm{Br}, \mathrm{I})$ complexes. Chem. Commun. 2013, 49, 10483-10485.

(72) Egbert, J. D.; Cazin, C. S. J.; Nolan, S. P. Copper N-heterocyclic carbene complexes in catalysis. Catal. Sci., Technol., 2013, 3, 912-926.

(73) Gruger, N.; Rodriguez, L.-I.; Wadepohl, H.; Gade, L. H. Achiral and chiral PNPpincer ligands with a carbazole backbone: coordination chemistry with $d^{8}$ transition metals. Inorg. Chem. 2013, 52, 2050-2059.

(74) Gao, R.; Zhang, T.; Wang, F.; Sun, W.-H. Nickel(II) complexes chelated by 2arylimino-6-benzoxazolylpyridine: synthesis, characterization and ethylene oligomerization. Organometallics 2008, 27, 5641-5648.

(75) Peters, J. C.; Harkins, S. B.; Brown, S. D.; Day, M. W. Pincer-like amido complexes of platinum, palladium and nickel. Inorg. Chem. 2001, 40, 5083-5091.

(76) Liu, N.; Wang' L.; Wang, Z.-X. Room-temperature nickel-catalyzed crosscouplings of aryl chlorides with arylzincs. Chem. Commun. 2011, 47, 1598-1600.

(77) Solin, N.; Kjellgren, J.; Szabó, K. J. Pincer complex-catalyzed allylation of aldehyde and imine substrates via nucleophilic $n^{1}$-allyl palladium intermediates. J. Am. Chem. Soc. 2004, 126, 7026-7033.

(78) Solin, N.; Kjellgren, J.; Szabó, K. J. Palladium-catalyzed electrophilic substitution via monoallylpalladium intermediates. Angew. Chem. Int. Ed. 2003, 42, 36563658.

(79) Yao, Q.; Sheets, M. A SeCSe-Pd(II) pincer complex as a highly efficient catalyst for allylation of aldehydes with allyltributyltin. J. Org. Chem. 2006, 71, 5384-5387. 
(80) Selander, N.; Sebelius, S.; Estay, C.; Szabó, K. J. Highly selective and robust palladium-catalyzed carbon-carbon coupling between allyl alcohols and aldehydes via transient allylboronic acids. Eur. J. Org. Chem. 2006, 4085-4087.

(81) Selander, N.; Willy, B.; Szabó, K. J. Selective C-H borylation of alkenes by palladium pincer complex catalyzed oxidative functionalization. Angew. Chem. Int. Ed. 2010, 49, 4051-4053.

(82) Nakamura, H.; Iwama, H.; Yamamoto, Y. Palladium- and platinum-catalyzed addition of aldehydes and imines with allylstannanes. Chemoselective allylation of imines in the presence of aldehydes. J. Am. Chem. Soc. 1996, 118, 66416647.

(83) Pilarski, L.; Szabó, K. J. Palladium pincer complex catalyzed functionalization of electrophiles. Curr. Org. Chem 2011, 15, 3389-3414.

(84) Aydin, J.; Szabó, K. J. Palladium-pincer complex catalyzed C-C coupling of allyl nitriles with tosyl imines via regioselective allylic $\mathrm{C}-\mathrm{H}$ bond functionalization. Org. Lett. 2008, 10, 2881-2884.

(85) Aydin, J.; Selander, N.; Szabó, K. J. Strategies for fine-tuning the catalytic activity of pincer-complexes. Tetrahedron Lett. 2006, 47, 8999-9001.

(86) Selander, N.; Szabó, K. J. Catalysis by palladium pincer complexes. Chem. Rev. 2011, 111, 2048-2076. 